\title{
REDES NEURAIS ARTIFICIAIS NA PREDIÇÃO DE RESPOSTAS E ESTIMAÇÃO DE DERIVADAS AERODINÂMICAS DE AERONAVES
}

Tese apresentada à Escola de Engenharia de São Carlos da Universidade de São Paulo para obtenção do título de Doutor em Engenharia Mecânica.

Área de Concentração: Aeronaves

Orientador: Prof. Titular. Eduardo Morgado Belo 
A Deus agradeço pon hudo que tenho!!!!!!!!!!! Especialmente por mens dois anjos sem asas: Zoũo Batistave Yolanda, meus pais.!!' A mens pais ofereço esta conquista! 
AGRADECIMENTOS

Agradeço a Deus primeiramente por ter concluído mais esta etapa de minha vida. Estou certa de que Ele esteve comigo em cada instante deste trabalho!

Ao meu orientador Prof. Titular Eduardo Morgado Belo pela orientação dos meus trabalhos de mestrado e doutorado, pela amizade e confiança depositada durante estes anos.

Ao Prof. Associado Flávio pela amizade e pelas importantes contribuições dadas desde o início do meu mestrado.

À Professora Dra. Roseli Francelin por todas as contribuições ao trabalho.

Novamente aos meus pais e aos meus irmãos José Ariovaldo, Fernanda e João Paulo pelo carinho e pelo estímulo dedicados. Ao meu lindo sobrinho Lucas, que tanto me faz feliz!

Às minhas grandes amigas, Kelen e Luciana, com as quais tive o prazer de dividir apartamento durante estes anos, meu eterno carinho e consideração. Em especial, agradeço muito à Kelen por todas as discussões sobre Redes Neurais, pelos momentos de descontração e pelos exemplos de vida que passou. À Luciana, pelas conversas, pela confiança e por tudo que fez por mim. Adoro vocês!

Meu carinho todo especial ao Geraldo e à Gi, pelo incentivo e amizade!!!!

À todos meus amigos do Laboratório: Andreia, Cláudio, Daniela, De Marqui, Édson, Elizangela, Márcio, Maurício, Caixeta e Naga, pelas conversas sobre o trabalho e pela amizade. Meu eterno carinho e amizade. Muito obrigada!!!

Meu carinho especial ao Osnan, Gisele, Jaque, Paulo Marcos, Paulo Roberto, Graziela e a todos os amigos aqui da USP. Aos meus amigos de Cerqueira: Zinho, Fabiano, Cássio, Marcinha, Mylene, Mirele, Alessandra, Bico, Angelinha, Viviane e Mazinha por sempre me incentivarem.

À CAPES pela bolsa de estudo concedida no início do meu doutorado. 


\section{SUMÁRIO}

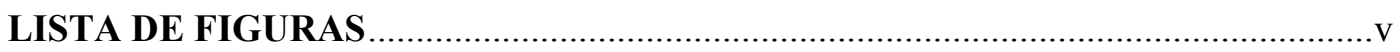

LISTA DE SÍMBOLOS …................................................................................ xiii

RESUMO

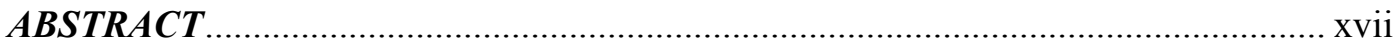

\section{CAPÍTULO 1}

Introdução

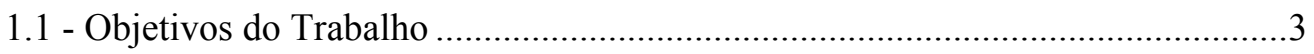

1.2 - Identificação de Sistemas............................................................................

1.2.1 - Breve introdução sobre as Redes Neurais Artificiais ...............................5

1.2.2. - Identificação de envelope de vôo via Redes Neurais Artificiais ...............7

1.3 - Estimação de parâmetros aerodinâmicos ............................................................8

1.3.1 - Estimação de parâmetros usando redes neurais artificiais........................11

1.4 - Organização da Tese .....................................................................................13

\section{CAPÍTULO 2}

\section{Alguns modelos de Redes Neurais Artificiais}

2.1 - Introdução. .15

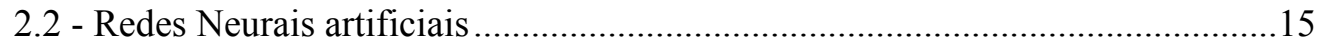

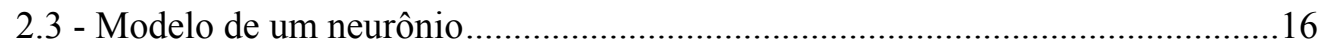

2.3.1 - Tipos de Função de Ativação ...................................................................17 
2.3.2. - Normalização dos dados..... .20

2.3.2.1 - Normalização através da Divisão pelo Valor Máximo Absoluto 20

2.4 - Redes Neurais Multicamadas .21

2.4.1 - Redes Neurais multicamadas feedforward ...........................................21

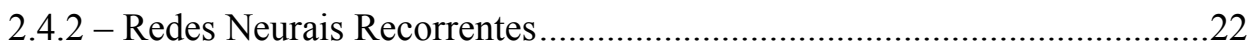

2.4.2.1 - Redes Neurais NARX .................................................................24

2.5 - Aprendizagem de uma rede neural ...............................................................25

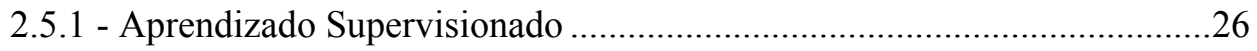

2.5.2 - Aprendizado não supervisionado .......................................................27

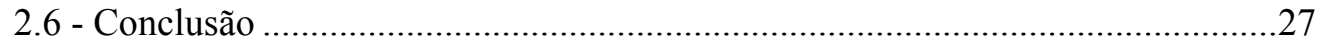

\section{CAPÍTULO 3}

\section{As equações de movimento}

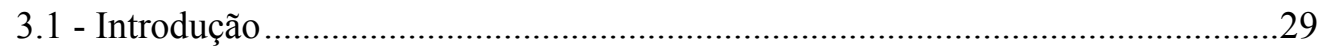

3.2 - Equações gerais de movimento não estacionário ...............................................30

3.3 - Equações de corpo rígido ..................................................................................

3.4 - Quantidade de movimento angular $\mathrm{h}$................................................................

3.5 - Orientação e posição da aeronave ...................................................................36

3.5.1 - Compondo os ângulos de Euler.............................................................37

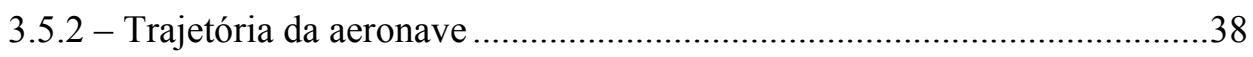

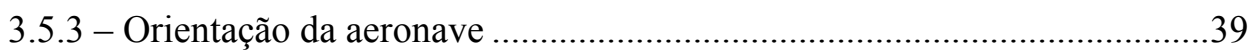

3.6 - Equações de movimento de Euler .....................................................................40

3.6.1 - Escolha dos eixos da aeronave …………..........................................42

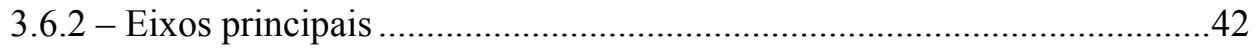

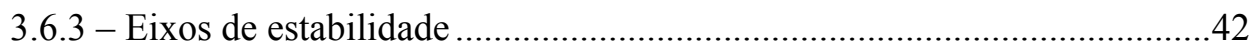

3.6.4 - Conjunto completo de equações de movimento ....................................43

3.6.5 - Discussão sobre as equações de movimento ………………………........44

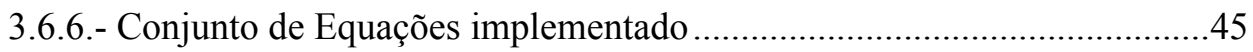


3.6.7 - Breve descrição da Teoria de pequenas perturbações .47

3.6.8 Carregamento Aerodinâmico Linear ..... .47

3.7 - Conclusões .51

\section{CAPÍTULO 4}

Resultados da Simulação e da Identificação das respostas de uma aeronave militar de ataque dentro de um envelope de vôo

4.1 - Introdução. .53

4.2 - Dados para simulação da aeronave usada para estudo de caso . .53

4.3 - Apresentação do envelope de vôo a ser identificado .56

4.3.1 - Simulação da dinâmica longitudinal da aeronave . .57

4.3.2 - Identificação da dinâmica longitudinal

4.3.2.1 - Abordagem sobre as redes neurais usadas na identificação.

4.3.2.2 - Resultados da identificação das respostas da aeronave dentro do envelope de vôo .64

4.3.2.2.1 - Resultados de testes realizados com a RNA para verificação do treinamento .64

4.3.2.2.2.- Resultados da generalização para pontos do envelope de vôo desconhecidos pela RNA

4.4 - Conclusões

\section{CAPÍtULO 5}

Resultados da Estimação das derivadas aerodinâmicas de estabilidade e controle usando redes neurais artificiais

5.1 - Introdução. .95

5.2 Estimação das derivadas aerodinâmicas usando resultados simulados de uma aeronave num envelope de vôo via RNA's

5.3 Resultados da estimação das derivadas aerodinâmicas da aeronave de ataque simulada A4-D. 
5.3.1 - Resultados da estimação das derivadas aerodinâmicas longitudinais $X_{u}$, $Z_{u}$ e $M_{u}$

5.3.2 - Resultado da estimação das derivadas aerodinâmicas lon gitudinais $M_{\dot{w}}$

e $M_{q}$ 103

5.3.3 - Resultado da estimação das derivadas aerodinâmicas longitudinais $X_{w}$, $Z_{w}$ e $M_{w}$ 105

5.4 - Comparação das respostas da aeronave usando as derivadas reais e estimadas 110 5.5 - Resultados experimentais 118

5.5.1 - Apresentação dos dados da aeronave Xavante AT-26 e do envelope de vôo em estudo 118

5.5.2 - Estimação das derivadas aerodinâmicas usando resultados obtidos em ensaio em vôo da aeronave Xavante AT-26 dentro de um envelope de vôo via RNA's..121

5.6. - Conclusões 133

\section{CAPÍTULO 6}

\section{Considerações Finais}

6.1 - Conclusões 135

6.2 - Propostas de continuidade do trabalho. 136 


\section{LISTA DE FIGURAS}

\section{CAPÍTULO 1}

Figura 1.1 - Identificação de um sistema dinâmico 4

\section{CAPÍTULO 2}

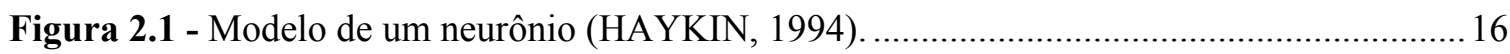

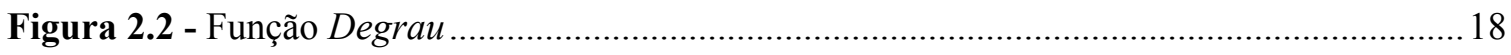

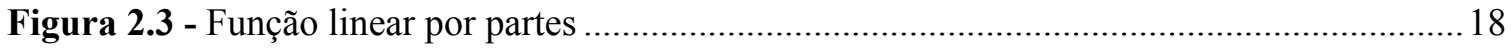

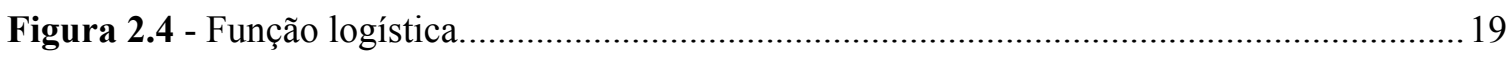

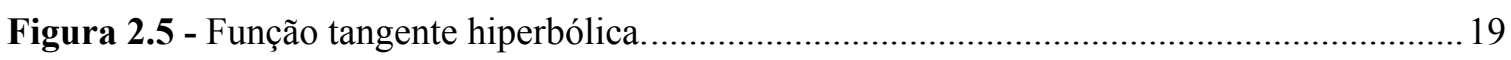

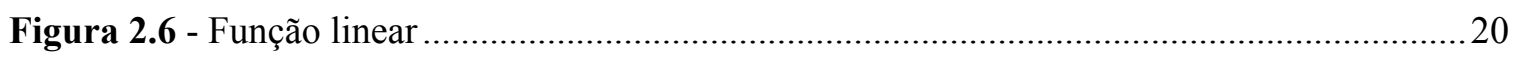

Figura 2.7 - Rede com três camadas (HAGAN et al., 1996) ........................................................22

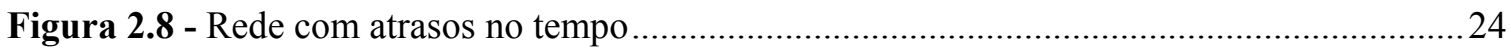

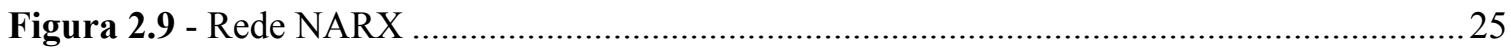

Figura 2.10 - Diagrama de blocos que representa um sistema com aprendizado supervisionado 26

\section{CAPÍTULO 3}

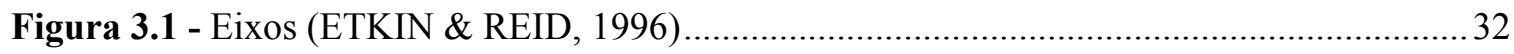

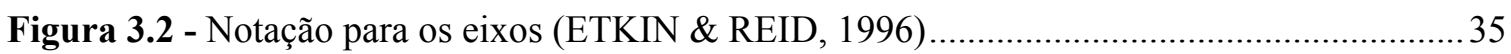

Figura 3.3 - Orientação da aeronave (ETKIN \& REID, 1996) ...................................................... 37

Figura 3.4 - Ilustração dos eixos da aeronave: (a) Eixos principais e (b) Eixos de estabilidade $\varepsilon>0$ .42

Figura 3.5 - Ilustração do esquema das Equações da aeronave 45 
Figura 3.6 - (a) Esquema mostrando relação entre $\beta$ e $v$. (b) Esquema mostrando relação entre $\alpha$ e $w$ (MARQUES, 2004)

Figura 3.7 - Ilustração do esquema mostrando relação entre $\beta$ e $v$ e $\alpha$ e (MARQUES, 2004)

\section{CAPÍTULO 4}

Figura 4.1 - Esquema do envelope de vôo a ser identificado.

Figura 4.2 - Respostas de velocidade horizontal obtidas em simulação da aeronave para as 9 condições de vôo apresentadas .58

Figura 4.3 - Respostas de velocidade vertical obtidas em simulação da aeronave. .58

Figura 4.4 - Respostas de velocidades verticais obtidas em simulação num intervalo menor de tempo 59

Figura 4.5 - Respostas de $q$ obtidas em simulação 59

Figura 4.6 - Respostas de $q$ obtidas em simulação. 60

Figura 4.7 - Respostas de $\theta$ (ângulo de arfagem) obtidas em simulação 60

Figura 4.8 - Esquema representativo dos pontos do envelope de vôo simulados 61

Figura 4.9 - Esquema representativo da rede neural recorrente usada na identificação 63

Figura 4.10 - Decaimento do erro durante o treinamento da rede. 64

Figura 4.11 - Resultado gerado pela RNA referente ao Caso 5 com entrada degrau de $12^{\circ}$........65

Figura 4.12 - Respostas de $w$ e $q$ apresentadas na Figura 4.11 até 50 segundos ......................65

Figura 4.13 - Resultado gerado pela RNA referente ao Caso 5 com entrada rampa..................66

Figura 4.14 - Resultado gerado pela RNA referente ao Caso 5 com entrada de 7,2 ${ }^{\circ}$...............6.67

Figura 4.15 - Respostas de $w(t)$ e $q(t)$ apresentadas na Figura 4.13 até 50 segundos

Figura 4.16 - Resultado gerado pela RNA referente ao Caso 5 com entrada de 3,8 no profundor68 Figura 4.17 - Respostas de $w(t)$ e $q(t)$ apresentadas na Figura 4.16 até 50 segundos. 68

Figura 4.18 - Resultado gerado pela RNA referente ao Caso 6 com entrada degrau de $5,1^{\circ}$ no profundor

Figura 4.19 - Respostas de $w$ e $q$ apresentadas na Figura 4.18 até 50 segundos .....

Figura 4.20 - Resultado gerado pela RNA referente ao Caso 6 com entrada degrau de $3,8^{\circ}$ no profundor..... 70

Figura 4.21 - Respostas de $w$ e $q$ apresentadas na Figura 4.20 até 50 segundos..... 70

Figura 4.22 - Resultado gerado pela RNA referente ao Caso 8 com entrada degrau de $1,9^{\circ}$ no profundor 
Figura 4.23 - Resultado gerado pela RNA referente ao Caso 8 com entrada degrau de $0,8^{\circ}$ no profundor .71

Figura 4.24 - Resultado gerado pela RNA referente ao Caso 8 com entrada degrau de $0,8^{\circ}$ no profundor

Figura 4.25 - Respostas de $w$ e $q$ apresentadas na Figura 4.24 até 50 segundos. .72

Figura 4.26 - Resultado gerado pela RNA referente ao Caso 8 com entrada degrau de $1,2^{\circ}$ no profundor. .73

Figura 4.27 - Respostas de $w$ e $q$ apresentadas na Figura 4.26 até 50 segundos .73

Figura 4.28 - Resultado gerado pela RNA referente ao Caso 9 com entrada degrau de $0,7^{\circ}$ no profundor .74

Figura 4.29 - Resultado gerado pela RNA referente ao Caso 9 com entrada degrau de $2,2^{\circ}$ no profundor .72

Figura 4.30 - Respostas de $w$ e $q$ apresentadas na Figura 4.29 até 50 segundos .75

Figura 4.31 - Resultado gerado pela RNA referente ao Caso 9 com entrada degrau de $1,1^{\circ}$ no profundor. .75

Figura 4.32 - Respostas de $w$ e $q$ apresentadas na Figura 4.31 até 50 segundos. .76

Figura 4.33 - Identificação das respostas da aeronave no Caso 1 do envelope de vôo após aplicação de degrau de 1,6 no profundor. .77

Figura 4.34 - Respostas de $w$ e $q$ apresentadas na Figura 4.33 até 50 segundos. .77

Figura 4.35 - Identificação das respostas da aeronave no ponto 1 do envelope de vôo após aplicação de sinal rampa juntamente com ruído no profundor .78

Figura 4.36 - Detalhes da entrada rampa, velocidade horizontal, velocidade vertical e velocidade de arfagem. .78

Figura 4.37 - Identificação das respostas da aeronave no ponto 1 do envelope de vôo após aplicação de sinal senoidal no profundor. .79

Figura 4.38 - Identificação das respostas da aeronave no ponto 1 do envelope de vôo após aplicação de trem de pulsos no profundor. 80

Figura 4.39 - Identificação das respostas da aeronave no ponto 1 do envelope de vôo após aplicação de entrada 3-2-1-1 no profundor 80

Figura 4.40 - Variações em $w$ e $q$ para o tempo de até 100 segundos. .81

Figura 4.41 - Identificação das respostas da aeronave no ponto 2 do envelope de vôo após aplicação de entrada degrau no profundor

Figura 4.42 - Respostas de velocidade vertical e de arfagem da aeronave para o tempo de até 50 segundos. 
Figura 4.43 - Identificação das respostas da aeronave voando em condições corresponden83tes ao ponto 2 do envelope de vôo após aplicação de trem de pulsos no profundor 83

Figura 4.44 - Identificação das respostas da aeronave no ponto 2 do envelope de vôo após aplicação de entrada senoidal no profundor

Figura 4.45 - Identificação das respostas da aeronave no ponto 2 do envelope de vôo após aplicação de entrada 3-2-1-1 no profundor .... 84

Figura 4.46 - Variações em $w$ e $q$ para o tempo de até 100 segundos 85

Figura 4.47 - Identificação das respostas da aeronave no ponto 3 do envelope de vôo após aplicação de entrada degrau no profundor. 85

Figura 4.48 - Variações de $w$ e $q$ até 50 segundos.. .86

Figura 4.49 - Identificação das respostas da aeronave no ponto 3 do envelope de vôo após aplicação de entrada trem de pulsos no profundor 86

Figura 4.50 - Identificação das respostas da aeronave no ponto 3 do envelope de vôo após aplicação de entrada 3-2-1-1 nos profundores.

Figura 4.51 - Variações em $w$ e $q$ para o tempo de até 100 segundos .87

Figura 4.52 - Identificação das respostas da aeronave no ponto 7 do envelope de vôo após aplicação de entrada degrau nos profundores. 88

Figura 4.53 - Variações em $w$ e $q$ para o tempo de até 50 segundos. 88

Figura 4.54 - Identificação das respostas da aeronave no ponto 7 do envelope de vôo após aplicação de entrada trem de pulsos nos profundores

Figura 4.55 - Identificação das respostas da aeronave no ponto 7 do envelope de vôo após aplicação de entrada do tipo senoidal nos profundores

Figura 4.56 - Identificação das respostas da aeronave no ponto 7 do envelope de vôo após aplicação de entrada 3-2-1-1 nos profundores. 90

Figura 4.57 - Variações em $w$ e $q$ para o tempo de até 100 segundos 90

Figura 4.58 - Identificação das respostas da aeronave no ponto 4 do envelope de vôo após aplicação de entrada degrau de $1,8^{\circ}$ nos profundores. 91

Figura 4.59 - Detalhes das variações em $w$ e $q$ para o tempo de até 50 segundos .91

Figura 4.60 - Identificação das respostas da aeronave no ponto 4 do envelope de vôo após aplicação de entrada 3-2-2-1 nos profundores. 92

Figura 4.61 - Identificação das respostas da aeronave no ponto 4 do envelope de vôo após aplicação de trem de pulsos nos profundores 92 


\section{CAPÍTULO 5}

Figura 5.1 - Diagrama de blocos mostrando a identificação das respostas da aeronave e suas respectivas derivadas.

Figura 5.2 - Diagrama de blocos representativo da RNA usada para estimar as derivadas longitudinais em $u$ .98

Figura 5.3 - Esquema representativo dos pontos do envelope de vôo simulados .99

Figura 5.4 - Decaimento do erro de treinamento nas RNA's usadas ... .99

Figura 5.5Respostas das derivadas estimadas e teóricas 102

Figura 5.6 - Comparação das respostas das derivadas estimadas e teóricas 104

Figura 5.7 - Diagrama de blocos mostrando a esquema da RNA usada para estimar as derivadas longitudinais $M_{\dot{w}}$ e $M_{q}$ 104

Figura 5.8 - Decaimento do erro de treinamento da rede neural usada. 105

Figura 5.9 - Respostas das derivadas estimadas e teóricas 107

Figura 5.10 - Diagrama de blocos mostrando a rede neural para estimar as derivadas longitudinais $X_{w}, Z_{w}$ e $M_{w}$ 107

Figura 5.11 - Decaimento do erro de treinamento da rede neural usada ...................................... 108

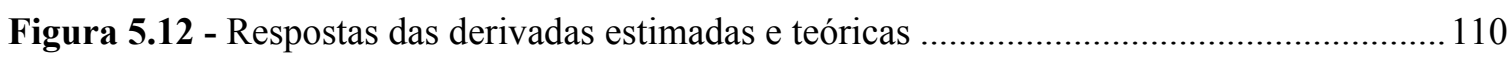

Figura 5.13 - Decaimento do erro de treinamento da rede neural usada .....................................110

Figura 5.14 - Respostas das derivadas estimadas e teóricas ....................................................... 111

Figura 5.15 - Entrada degrau usada no profundor.

Figura 5.16 - Respostas de variação de u usando derivadas reais e estimadas para o caso 1

Figura 5.17 - Respostas de variação de w usando derivadas reais e estimadas para o caso 1

Figura 5.18 - Respostas de variação de q usando derivadas reais e estimadas para o caso 1

Figura 5.19 - Entrada pulso juntamente com ruído usada no profundor 114

Figura 5.20 - Respostas de variação de $u$ usando derivadas reais e estimadas para o caso1

Figura 5.21 - Respostas de variação de $w$ usando derivadas reais e estimadas para o caso 1

Figura 5.22 - Respostas de variação de $q$ usando derivadas reais e estimadas para o caso 1 
Figura 5.23 - Entrada pulso juntamente com ruído usada no profundor . .115

Figura 5.24 - Respostas de variação de $u$ usando derivadas reais e estimadas para o caso 2 ......115

Figura 5.25 - Respostas de variação de $w$ usando derivadas reais e estimadas para o caso 2 .....116

Figura 5.26 - Respostas de variação de $q$ usando derivadas reais e estimadas para o caso 2 ............

Figura 5.27 - Entrada 3-2-1-1 usada no profundor. 116

Figura 5.28 - Respostas de variação de $u$ usando derivadas reais e estimadas para o caso $2 \ldots . . .116$

Figura 5.29 - Respostas de variação de $w$ usando derivadas reais e estimadas para o caso 2 .....117

Figura 5.30 - Respostas de variação de $q$ usando derivadas reais e estimadas para o caso $2 \ldots . . .117$

Figura 5.31 - Entrada 3-2-1-1 usada no profundor. 117

Figura 5.32 - Respostas de variação de $u$ usando derivadas reais e estimadas para o caso 3 ......117

Figura 5.33 - Respostas de variação de $w$ usando derivadas reais e estimadas para o caso 3 .....118

Figura 5.34 - Respostas de variação de $q$ usando derivadas reais e estimadas para o caso 3 ......118

Figura 5.35 - Entrada 3-2-1-1 usada no profundor.

Figura 5.36 - Respostas de variação de $u$ usando derivadas reais e estimadas para o caso 4 ......118

Figura 5.37 - Respostas de variação de $w$ usando derivadas reais e estimadas para o caso 4 ....119

Figura 5.38 - Respostas de variação de q usando derivadas reais e estimadas para o caso 4 .......119

Figura 5.39 - Entrada usada no profundor.

Figura 5.40 - Respostas de variação de $u$ usando derivadas reais e estimadas para o caso $7 \ldots . . .119$

Figura 5.41 - Respostas de variação de $w$ usando derivadas reais e estimadas para o caso 7 ....120

Figura 5.42 - Respostas de variação de $q$ usando derivadas reais e estimadas para o caso $7 \ldots . .120$

Figura 5.43 - Esquema do envelope de vôo da aeronave AT-26 Xavante, mostrando os pontos nos quais foram analisadas respostas da aeronave

Figura 5.44 - Ampliação de uma região no envelope comparando os valores usados em treinamento, generalização e os usados para realizar a estimação

Figura 5.45 - Diagrama de blocos representativo da RNA usada na estimação das derivadas aerodinâmicas de estabilidade e controle

Figura 5.46 - Entrada de profundor e gráficos comparativos de resultados reais e resultados obtidos usando derivadas estimadas pela RNA correspondentes ao caso 25 do envelope de vôo.....

Figura 5.47 - Entrada de profundor e gráficos comparativos de resultados reais e resultados obtidos usando derivadas estimadas pela RNA correspondentes ao caso 25 do envelope de vôo ..... 
Figura 5.48 - Entrada de profundor e gráficos comparativos de resultados reais e resultados obtidos usando derivadas estimadas pela RNA correspondentes ao caso 34 do envelope de vôo.....

Figura 5.49 - Entrada de profundor e gráficos comparativos de resultados reais e resultados obtidos usando derivadas estimadas pela RNA correspondentes ao caso 11 do envelope de vôo.....

Figura 5.50 - Entrada de profundor e gráficos comparativos de resultados reais e resultados obtidos usando derivadas estimadas pela RNA correspondentes ao caso 12 do envelope de vôo.....

Figura 5.51 - Entrada de profundor e gráficos comparativos de resultados reais e resultados obtidos usando derivadas estimadas pela RNA correspondentes ao caso 16 do envelope de vôo.....

Figura 5.52 - Entrada de profundor e gráficos comparativos de resultados reais e resultados obtidos usando derivadas estimadas pela RNA correspondentes ao caso 23 do envelope de vôo.....

Figura 5.53 - Entrada de profundor e gráficos comparativos de resultados reais e resultados obtidos usando derivadas estimadas pela RNA correspondentes ao caso 29 do envelope de vôo.....

Figura 5.54 - Entrada de profundor e gráficos comparativos de resultados reais e resultados obtidos usando derivadas estimadas pela RNA correspondentes ao caso 51 do envelope de vôo.....

Figura 5.55 - Entrada de profundor e gráficos comparativos de resultados reais e resultados obtidos usando derivadas estimadas pela RNA correspondentes ao caso 24 do envelope de vôo.....

Figura 5.56 - Entrada de profundor e gráficos comparativos de resultados reais e resultados obtidos usando derivadas estimadas pela RNA correspondentes ao caso 39 do envelope de vôo.....

Figura 5.57 - Entrada de profundor e gráficos comparativos de resultados reais e resultados obtidos usando derivadas estimadas pela RNA correspondentes ao caso 19 do envelope de vôo..... 


\section{SÍMBOLOS}

$\delta_{e}, \delta_{a}$ e $\delta_{r}$ : ângulos de profundor, aileron e leme respectivamente e ainda:

$X_{u}$ : variação da força em $X$ devido a uma mudança na velocidade para frente $u$.

$X_{w}$ : variação da força em $X$, devido a mudanças na velocidade vertical $w$.

$X_{\delta_{e}}$ : variação da força em $\mathrm{X}$, devido a mudanças no ângulo do profundor $\delta_{e}$.

$Y_{v}$ : variação da força em $Y$, devido a mudanças na velocidade lateral $v$.

$Y_{p}$ : variação da força em $Y$, devido a mudanças na velocidade de rolagem.

$Y_{r}$ : variação da força em $Y$, devido a mudanças na velocidade $r$ de guinada.

$Y_{\delta_{r}}$ : variação da força em $Y$ devido a mudanças no ângulo de deflexão do leme $\delta_{r}$.

$Z_{u}$ : variação da força em $Z$, devido a mudanças na velocidade $u$.

$Z_{w}$ : variação da força em $Z$ devido a mudanças na velocidade vertical $w$.

$Z_{\dot{w}}$ : variação da força em $Z$, devido a variação na aceleração vertical $\dot{w}$.

$Z_{q}$ : variação da força em $Z$, devido a mudanças na velocidade de arfagem $q$.

$Z_{\delta_{e}}$ : variação da força em Z, devido a mudanças no ângulo de deflexão do profundor $\delta_{e}$.

$L_{v}$ : variação do momento $\mathbf{L}$ devido a mudanças na velocidade lateral $v$.

$L_{p}$ : variação no momento de rolagem devido à velocidade de rolagem $p$.

$L_{r}$ : variação no momento $\mathbf{L}$ devido a mudanças na velocidade de guinada $\mathrm{r}$.

$L_{\delta_{a}}$ : variação no momento $\mathbf{L}$ devido a mudanças no ângulo de deflexão dos ailerons $\delta_{a}$.

$L_{\delta_{r}}$ : variação no momento L devido a mudanças no ângulo de deflexão do leme $\delta_{r}$. 
xiv

$M_{u}$ : variação no momento $\mathbf{M}$ devido a uma mudança na velocidade para a frente $u$.

$M_{w}$ : variação no momento $\mathbf{M}$ devido a mudanças na velocidade vertical $w$.

$M_{\dot{w}}$ : variação no momento $\mathbf{M}$ devido a mudanças na aceleração $\dot{w}$.

$M_{q}$ : variação no momento $\mathbf{M}$ devido a mudanças na velocidade de arfagem $q$.

$M_{\delta_{e}}$ : variação no momento $\mathbf{M}$ devido a mudanças no ângulo de deflexão do profundor $\delta_{e}$.

$N_{v}$ : variação no momento $\mathbf{N}$ devido a mudanças na velocidade lateral $v$.

$N_{p}$ : variação no momento $\mathbf{N}$ devido a mudanças na velocidade de rolagem $p$.

$N_{r}$ : variação no momento $\mathbf{N}$ devido a mudanças na velocidade de guinada $r$. Este momento é normalmente negativo.

$N_{\delta_{a}}$ : variação no momento $\mathbf{N}$ devido a mudanças no ângulo de deflexão dos ailerons $\delta_{a}$.

$N_{\delta_{r}}$ : variação no momento $\mathrm{N}$ devido a mudanças no ângulo de deflexão do leme $\delta_{r}$.

DAE: derivadas aerodinâmicas de estabilidade

RD: respostas desejadas

RI: respostas identificadas

RNF: rede neural feedforward

RNR: rede neural recorrente 


\section{RESUMO}

SOUZA, L. F. R. (2007). Redes Neurais Artificiais na predição de respostas e estimação de derivadas aerodinâmicas de aeronaves. São Carlos, 2007. Tese (Doutorado) - Escola de Engenharia de São Carlos, Universidade de São Paulo.

A área de dinâmica de aeronaves atingiu um alto nível de desenvolvimento e devido à crescente disponibilidade de computadores cada vez mais rápidos e com maior capacidade de processamento; a aplicação de técnicas numéricas de identificação nesta área também teve grande avanço. Este trabalho apresenta uma metodologia para predição de respostas de aeronaves dentro de envelopes de vôo pré-estabelecidos usando redes neurais recorrentes e uma metodologia para estimação das suas derivadas aerodinâmicas usando redes neurais feedforward. Para obter os conjuntos de dados para treinar as redes neurais, foi implementado um modelo não linear de dinâmica de vôo e simulado o comportamento de uma aeronave de combate em nove pontos de um envelope de vôo. Foram usadas as respostas simuladas correspondentes a quatro pontos para treinar a rede neural e depois disto, esta capturou satisfatoriamente a dinâmica da aeronave, identificando com grande sucesso as respostas do movimento longitudinal da aeronave por todo o envelope de vôo considerado. Após a simulação e identificação das respostas da aeronave dentro do envelope de vôo, é apresentada a resolução do problema inverso, ou seja, usando velocidades escalares e angulares da aeronave juntamente com seus dados geométricos como entradas para a rede neural feedforward, é obtido um modelo neural estimador de derivadas aerodinâmicas. Para mostrar a capacidade deste modelo neural estimador, este é aplicado na estimação das derivadas da aeronave simulada e também aplicado na estimação das derivadas aerodinâmicas da aeronave militar a jato Xavante AT-26 da Força Aérea Brasileira. Estas metodologias propostas reduzem custo de obtenção das derivadas aerodinâmicas e mostram a eficácia das redes neurais em estimar as respostas de aeronaves dentro de um envelope de vôo pré-definido.

Palavras-chave: Predição, Redes Neurais Artificiais, Dinâmica de vôo, Envelope de vôo. 


\begin{abstract}
SOUZA, L. F. R. (2007). Artificial neural networks for prediction of responses and estimation of aerodynamic derivatives of aircraft. São Carlos, 2007. Tese (Doutorado) Escola de Engenharia de of São Carlos, Universidade de São Paulo, Brasil.

The area of aircraft dynamics has reached a high level of development and due to the increasing availability of computers continuously faster and with bigger processing capacity, the application of numerical identification techniques in this area also had great advance. This work presents two methodologies, one for prediction of aircraft responses within a preestablished flight envelope using recurrent neural networks and another one for estimation of its aerodynamic derivatives using feedforward neural networks. To get data sets to train the neural networks, a combat aircraft flight dynamics non-linear model was implemented and simulated in nine points of the flight envelope to obtain its behavior. The simulated responses corresponding to a four points of the flight envelope were used to train the neural network and after that, it was possible to verify that this net satisfactorily captured the dynamics of the aircraft, identifying with great success the longitudinal motion responses of the aircraft at all the considered flight envelope positions. After the simulation and identification of the aircraft responses inside the flight envelope, the solution of the inverse problem is presented, i.e., using scalar and angular aircraft velocities together with its geometric data as input to the feedforward neural network, a neural estimator model of aerodynamic derivatives is obtained. In order to show the capacity of this neural estimator model, this model is applied to the estimation of the derivatives of the simulated aircraft as well as to the estimation of the aerodynamic derivatives of a Brazilian Air Force military jet aircraft, the Xavante AT-26. These proposed methodologies reduce the cost of obtaining the aerodynamic derivatives and show the estimation effectiveness of the neural networks to estimate the responses of an aircraft inside a pre-defined flight envelope.
\end{abstract}

Key words : Prediction, Artificial Neural Networks, Flight Dynamics, Flight Envelope 


\section{CAPÍTULO 1}

\section{INTRODUÇÃO}

A dinâmica de vôo é a área da engenharia aeronáutica que estuda o movimento de veículos voando pela atmosfera. A natureza complexa da atmosfera, o comportamento dinâmico de uma aeronave, o uso de materiais compósitos causando uma redução de peso são alguns dos fatores que garantem a esta área problemas desafiadores (MARQUES, 2003).

O piloto, durante um vôo, deve ter a garantia de que a execução de manobras não causará nenhum prejuízo à estrutura da aeronave e conseqüentemente à tripulação. Para isto, deve ter conhecimento de todos os aspectos do envelope de vôo e dos limites do projeto da aeronave. É durante o carregamento da aeronave que é determinada a quantidade máxima de combustível, carga útil e passageiros permitidos pelo projeto da aeronave para que sejam mantidos os limites previstos no envelope de vôo desta.

Todos estes fatos mencionados anteriormente fazem com que haja necessidade de que as dinâmicas da aeronave sejam perfeitamente conhecidas. Isto faz com que haja um grande interesse no uso de simuladores de vôo. Várias bibliografias que apresentam modelos matemáticos de dinâmica de aeronaves fornecem resultados bastante próximos dos reais. Alguns destes modelos matemáticos são formados por equações que são representadas por polinômios em variáveis de estado, cujos coeficientes são derivadas aerodinâmicas. Para a simulação de uma aeronave é necessário o conhecimento destas derivadas, mas na prática elas não são facilmente conseguidas. Poucas são as aeronaves cujas derivadas estão apresentadas na literatura e, na prática, não é uma tarefa trivial a obtenção destas, já que é necessária a aplicação de técnicas de dinâmica dos fluidos computacional, ensaios em túnel de vento, ensaios em vôo, etc. As empresas guardam estes 
coeficientes em grande sigilo, pois são fundamentais para o projeto de novas aeronaves, compreensão de sua dinâmica de vôo, adaptação de sistemas de piloto automático, etc (MACIEL, 2007). Além do mais, simulações de efeitos não lineares em aeronaves usando métodos tradicionais podem ser caras computacionalmente e de difícil implementação. Por isso, o uso de métodos de identificação em casos em que não é fácil a obtenção de um conjunto de equações capazes de prever o comportamento de um sistema, tem sido bastante explorado.

Segundo NAKO (2003), a identificação de sistemas tem grande aplicabilidade na indústria, em particular na indústria aeronáutica pois pode ajudar no desenvolvimento de vários sistemas de controle de uma aeronave, como piloto automático, possibilita o desenvolvimento de simuladores mais precisos e realistas e sistemas Fly-By-Wire.

Os passos para iniciar a identificação de um sistema, quando se trata do desenvolvimento de um experimento real são: realização de medidas, escolha de métodos e modelos, decisão das manobras a serem realizadas e ao final a verificação dos resultados. Ou seja, é necessário que seja feita a seleção do sistema de instrumentação, das condições de vôo e das manobras da aeronave. O sistema de instrumentação é primeiramente usado para medir as variáveis de entrada e saída no tempo. As variáveis de entrada são representadas por deflexões das superfícies de controle, algumas vezes incluindo entradas de manche e pedal e forças correspondentes. As variáveis de saída incluem dados como velocidade do ar, variações de ângulo de ataque, velocidades angulares, acelerações lineares e angulares e ângulos de Euler. Além dessas variáveis, outras como temperatura externa para a avaliação da densidade do ar, consumo de combustível para a estimação da posição, do peso e inércias do centro de gravidade do avião podem ser usadas também. A segunda parte do desenvolvimento de um experimento é a especificação das formas de entradas que serão usadas para obter um conjunto de manobras desejadas para a estimação de parâmetros e determinação da estrutura do modelo (KLEIN, 1989).

No caso de trabalhos onde são realizadas simulações e não experimento real observa-se que o procedimento é análogo, ou seja, é necessária uma análise do tipo de modelo a ser desenvolvido, das entradas a serem usadas para que o sistema produza respostas desejadas, permitindo assim a obtenção de um conjunto de dados de entrada e saída representativos do sistema. Sem este conjunto de dados de entrada-saída não é possível a realização do processo de identificação. 
As Redes Neurais Artificiais surgem como mais uma ferramenta poderosa, permitindo a modelagem dos processos através de identificação, utilizando-se dos dados de entrada e saída dos mesmos. Têm se mostrado também estimadores de parâmetros bastante eficazes, aplicáveis em reconhecimento de padrões, na área de controle de processos, em problemas de otimização ou previsão devido à sua capacidade de aprendizado assim como o seu processamento paralelo (CRUZ, 1998).

Por possuírem, além de todas as vantagens dos métodos não convencionais, velocidade de processamento razoavelmente alta comparada a outros métodos convencionais e capacidade de aprendizagem, espelhando-se no comportamento humano, as Redes Neurais artificiais têm sido exploradas para análise e controle de sistemas dinâmicos não lineares. Para capturar a dinâmica de componentes, as redes neurais recorrentes com atrasos no tempo são exploradas e, para a estimação de parâmetros, as redes multicamadas feedforward.

\subsection{Objetivos do Trabalho}

Os objetivos deste trabalho são apresentar o desenvolvimento e implementação de um simulador de vôo confiável, identificação das respostas de uma aeronave dentro de um envelope de vôo pré-estabelecido e finalmente mostrar a resolução do problema inverso, ou seja, usando as respostas estimadas da aeronave, conseguir estimar as derivadas aerodinâmicas desta.

Para o desenvolvimento do modelo matemático da aeronave serão usadas as equações de movimento não linearizadas apresentadas em ETKIN (1996) e para a implementação será usado o software Simulink ${ }^{\circledR}$. O objetivo desta fase do trabalho é desenvolver um simulador para obter respostas de algumas condições de vôo de uma aeronave de combate, usada para este estudo de caso, para posteriormente usá-las no treinamento de redes neurais artificiais recorrentes para alguns pontos do envelope de vôo e verificar se elas são capazes de identificar o comportamento da aeronave para outros pontos do envelope. Destaca-se que será analisada apenas a dinâmica longitudinal da aeronave.

Após a simulação e identificação das respostas da aeronave dentro do envelope de vôo, será resolvido o problema inverso. Respostas de velocidades escalares e angulares da aeronave obtidas através da identificação, em variados pontos do envelope de vôo juntamente com seus dados geométricos serão fornecidas como entradas para uma outra rede multicamadas visando a obtenção de um modelo neural estimador de derivadas aerodinâmicas de estabilidade. Para mostrar 
a capacidade do modelo estimativo neural, este será também aplicado na estimação das derivadas aerodinâmicas da aeronave militar a jato Xavante AT-26 da Força Aérea Brasileira. Esta técnica proposta reduz custo de obtenção das derivadas aerodinâmicas e mostra a eficácia das redes neurais em estimar as respostas de aeronaves dentro de um envelope de vôo pré-definido. Portanto, as contribuições a serem mais destacadas neste trabalho são dois modelos de redes neurais artificiais com topologias simples, sendo uma recorrente capaz de identificar estados de aeronaves dentro de envelopes de vôo e outro uma rede multicamadas feedforward para estimação de derivadas aerodinâmicas.

\subsection{Identificação de Sistemas}

Identificação de sistemas é uma técnica usada para estabelecer um modelo matemático de um sistema dinâmico a partir de medidas de dados de entrada e saída do mesmo (KLEIN, 1989). A aplicação de técnicas de identificação na área de dinâmica de aeronaves atingiu um alto nível de desenvolvimento com a crescente disponibilidade de computadores cada vez mais rápidos e com maior capacidade de processamento. Em KLEIN (1989) encontra-se um esquema geral do procedimento de identificação de aeronaves, que está mostrado na forma de diagrama de blocos na Figura 1, e são também descritas detalhadamente as várias etapas do processo de identificação. Uma vasta revisão bibliográfica sobre o assunto pode ser também encontrada neste trabalho.

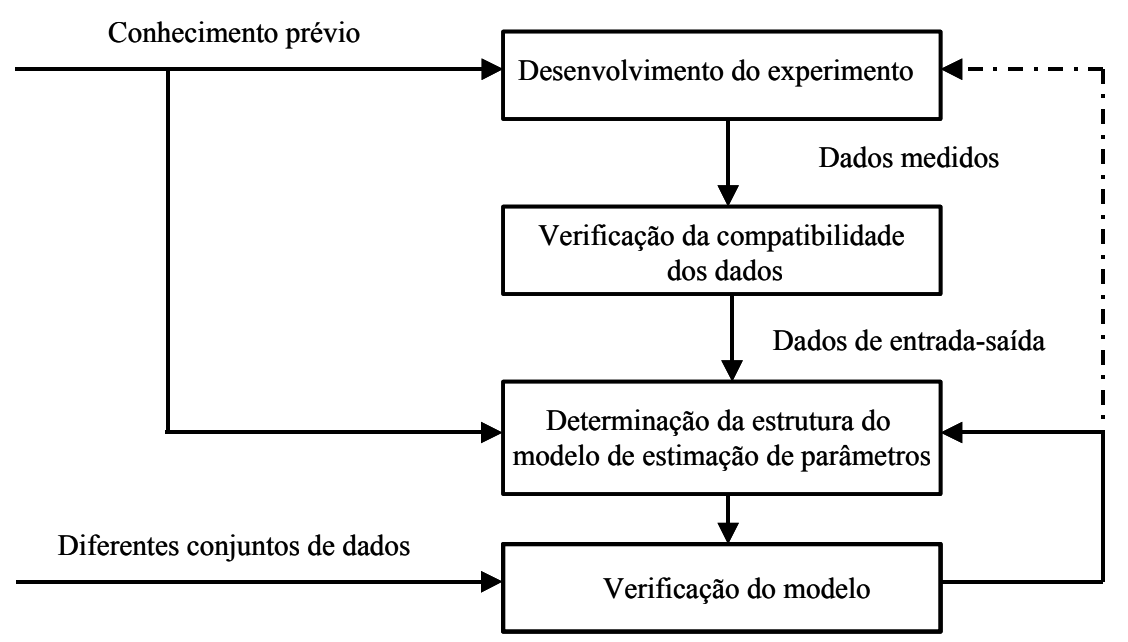

Figura 1.1. Diagrama de blocos do procedimento de identificação de aeronaves (KLEIN, 1989).

MORELLI (1998) apresentou uma abordagem para a identificação de sistemas para aeronaves que consiste de desenvolvimento experimental e análise de dados que pode ser implementada em tempo real e repetida a bordo de uma aeronave. Este esquema recursivo de 
identificação em vôo tem muitas vantagens aumentando a eficiência dos testes em vôo, maior adaptabilidade para encontrar características dinâmicas que não são conhecidas a priori, melhoria de qualidade de dados de vôo por iteração de dados de entrada e avaliação imediata da qualidade de resultados de teste de vôo. Foi explorada a técnica erro de equação no domínio da freqüência com a transformada de Fourier recursiva para esta abordagem de análise de dados de ensaios em vôo em tempo real. Foram mostrados exemplos simulados de manobras para demonstrar que a técnica produziu parâmetros bastante satisfatórios. Conclui-se que o método tem exigências computacionais razoavelmente baixas e pode ser implementado a bordo da aeronave em tempo real.

\subsubsection{Breve introdução sobre as Redes neurais Artificiais}

Como visto anteriormente, vários métodos de identificação têm sido propostos e verificados. Estes métodos aliados a técnicas não convencionais, como redes neurais artificiais, algoritmos genéticos, lógica difusa e outros estão sendo muito explorados ultimamente (SOUZA, 2002).

A história de redes neurais tem progredido através de inovações de conceitos e desenvolvimento de implementações. Alguns dos trabalhos práticos no campo de redes neurais ocorreram no fim do século XIX e início do século XX. Do ponto de vista moderno, os estudos sobre redes neurais foram iniciados em 1943 com o trabalho de Warren McCulloch e Walter Pitts (HAYKIN, 1994). McCULLOCH \& PITTS (1943), mostraram que redes de neurônios artificiais podem, em princípio, calcular qualquer função aritmética ou lógica. McCulloch e Pitts foram seguidos por Donald Hebb, o qual propôs um mecanismo de aprendizado em neurônios biológicos. Donald Hebb propôs um algoritmo de aprendizado baseado no reforço de ligações sinápticas, ou seja, variação de pesos de entrada (LIANG, 2002).

A primeira aplicação prática de redes neurais artificiais foi em 1950, com a invenção da rede perceptron associada à regra de aprendizado de Frank Rosenblatt (HAGAN, 1996). Rosenblatt construiu uma rede perceptron e demonstrou sua habilidade de reconhecimento de padrões. Os primeiros sucessos estimularam um grande número de pesquisadores a desenvolver trabalhos com redes neurais. Posteriormente foi mostrado que a base da rede perceptron resolve somente uma classe limitada de problemas. Ao mesmo tempo, Bernard Widrow e Tedd Hoff introduziram um novo algoritmo de aprendizado e o usaram para treinar rede neural linear adaptativa, o qual era similar na estrutura e capacidade ao perceptron de Rosenblatt. A regra de 
aprendizado de Widrow-Hoff, conhecida como Regra Delta, ainda é usada hoje. Segundo HAGAN (1996), as redes de Rosenblatt e Widrow sofriam as mesmas limitações e, Rosenblatt e Widrow, cientes dessas limitações, propuseram uma nova rede que poderia superar essas limitações. Mas eles não foram capazes de modificar com sucesso o algoritmo de aprendizado para treinar redes mais complexas.

Muitas pessoas, influenciadas por Minsky e Papert, acreditavam que não existiriam mais pesquisas sobre redes neurais. Isto combinou com o fato que não existiam computadores com capacidade para executarem os programas de redes neurais, fazendo com que muitos pesquisadores deixassem de fazer pesquisas nesta área. Pesquisas em redes neurais foram praticamente suspensas durante décadas.

Alguns trabalhos importantes continuaram durante os anos 70. Em 1972 Teuvo Kohonen e James Anderson, independentemente, desenvolveram novas redes neurais que poderiam atuar de maneira semelhante à memória humana.

Durante os anos 80 a pesquisa em redes neurais aumentou substancialmente. Novos computadores e Workstations, os quais aumentaram rapidamente sua capacidade, tornaram-se amplamente úteis. Além disso, novas concepções importantes foram introduzidas.

Duas dessas novas concepções foram responsáveis pelo renascimento de redes neurais. A primeira foi o uso de mecânica estatística para explicar a operação de uma certa classe de redes recorrentes, as quais podem ser usadas como uma memória associativa. O segundo desenvolvimento chave dos anos 80 foi o algoritmo backpropagation (retropropagação) para treinar redes perceptron com várias camadas, o qual foi desenvolvido independentemente por vários pesquisadores. A publicação de maior influência deste algoritmo foi feita por David Rumelhart e James McClelland (HAGAN, 1996). Este algoritmo foi a resposta para as críticas feitas por Minsky e Papert nos anos 60 (HAGAN et al., 1996).

Esses desenvolvimentos revigoraram o campo de redes neurais incentivando novas pesquisas e encontrando novas aplicações (HAGAN et al., 1996).

Foi a publicação de NARENDRA e PARTHASARATHY (1990) que colocou de forma clara o problema da aplicabilidade de redes multicamadas à identificação e posterior controle de dinâmicas não lineares. Segundo os autores esta identificação pode ser feita através de dois 
modelos: série-paralela e paralela. Na identificação série-paralela, é apresentado à rede um conjunto de entradas e saídas obtidas da simulação numérica do sistema. A rede é alimentada com as entradas no tempo corrente, seus respectivos atrasos e os atrasos das saídas. É utilizada para isto uma rede feedfoward com treinamento supervisionado para predizer a saída no tempo corrente, isto é, saídas anteriores medidas do sistema são usadas como entradas correntes na rede. HAYKIN (2001) chama este modelo de Rede Alimentada Adiante Focada Atrasada no Tempo, pois como visto anteriormente, não depende apenas de valores presentes da rede, mas também de seus valores passados. Para o treinamento deste tipo de rede, pode ser utilizado o algoritmo backpropagation. $\mathrm{Na}$ identificação paralela é apresentado à rede um conjunto de entradas e saídas obtidas da simulação numérica do sistema. A rede é alimentada com as entradas no tempo corrente, seus respectivos atrasos e os atrasos das saídas estimadas. É utilizada uma rede recorrente neste tipo de modelo.

As redes neurais artificiais, depois da publicação de NARENDRA e PARTHASARATHY (1990), têm sido amplamente utilizadas na identificação de sistemas, pois demonstram grande capacidade de aproximação de modelos não lineares, grande desempenho em análise da dinâmica de sistemas flexíveis e são fáceis de implementar. Uma grande vantagem de sua aplicação é a geração de dados em tempo real, visto que alguns meios convencionais de simulação de dinâmica não linear não podem gerar dados em tempo real (SARAVANAN \& DUYAR, 1993), além de outras desvantagens.

\subsubsection{Identificação de envelope de vôo via Redes neurais Artificiais}

É esperado que as aeronaves, num futuro bastante próximo, operem normalmente com alto índice de desempenho e manobrabilidade em regimes de vôo onde a aerodinâmica é altamente não linear. O envelope de vôo, que é um diagrama velocidade versus altitude, expandiu-se de tal maneira que as variações na pressão dinâmica passaram a ser bastante significativas. Grandes variações na pressão dinâmica implicam grandes variações na forma como uma aeronave comporta-se durante o vôo. Os coeficientes aerodinâmicos são afetados pela compressibilidade do ar (número de Mach) e pela orientação da aeronave em relação ao vetor velocidade. As propriedades de massa também se modificam durante o vôo, de acordo com o carregamento ou com o consumo de combustível. Tudo isso, de uma forma ou de outra, afeta o comportamento dinâmico da aeronave. Um modo que é estável e adequadamente amortecido em certo ponto do envelope de vôo pode tornar-se instável e pouco amortecido em outro ponto, dificultando ou até tornando impossível a pilotagem. Ou seja, as aeronaves modernas estão susceptíveis a uma 
variedade de limites complexos nos envelopes de vôo e que, normalmente é difícil do piloto descobrir o início de tais limites, na prática é comum impor para não correr riscos, limites operacionais. Isto restringe o verdadeiro desempenho e manobrabilidade da aeronave (HORN et al., 1998). Todas estas razões fazem com que a expansão do envelope de vôo de uma aeronave se torne assunto extremamente importante, mas para ser possível a expansão de um envelope de vôo é necessária a identificação deste.

LINSE \& STENGEL, (1993) usaram redes neurais recorrentes multicamadas associadas ao método de filtro de Kalman extendido para expandir e identificar um envelope de vôo de um jato de transporte. O filtro de Kalman-Bucy extendido foi usado para a estimação de estados e coeficientes de força normal e redes neurais para a modelagem aerodinâmica da aeronave. Para treinar as redes usaram entradas estáticas e dinâmicas, ou seja, foram incorporadas informações das derivadas de força e respostas obtidas das simulações de algumas condições de vôo. Conhecidos dados correspondentes a 60 pontos do envelope, foram usados dados de 8 pontos durante treinamento e depois usados os dados dos pontos restantes para verificar a capacidade de identificação da rede. Foi mostrado que os resultados de generalização obtidos foram bastante satisfatórios.

HORN et al. (1998) apresentaram um modelo de rede neural para fornecer informações sobre limites de envelope de vôo, ou seja, como expandi-los. Aplicaram o método para prover informações sobre fator de carga normal e ângulo de ataque limite da aeronave tilt-rotor V-22. A rede neural foi treinada off-line usando dados de simulação. Depois de treinada, foram feitos testes também simulados objetivando saber se poderia ser usada para predizer em tempo-real qual deflexão do controle longitudinal faria com que a aeronave excedesse o limite seguro de vôo. Os resultados mostraram que o sistema permitiu que a aeronave pudesse ser manobrada ao longo do envelope de vôo sem exceder os limites. Concluíram que as redes neurais têm grande potencial para predição de limites de envelope de vôo complexos.

\subsection{Estimação de parâmetros aerodinâmicos}

Vários métodos de identificação de parâmetros aerodinâmicos, tanto no domínio do tempo como no domínio da freqüência têm sido usados e propostos.

HAMEL \& JATEGAONKAR (1996) apresentaram uma breve revisão de vários métodos modernos de estimação de parâmetros e um pouco da história da identificação de sistemas aplicada 
a veículo de vôo. Mostraram o sucesso da metodologia de identificação de sistemas a um grande campo de problemas de modelagem de veículos de vôo e apresentaram vários resultados que, comparados a outras aplicações realizadas durante o passado recente, permitiram observar o amadurecimento da área de identificação.

ILIFF \& WANG (1997) aplicaram o método erro de equação para estudar as características de estabilidade e de controle da aeronave F-18, considerando esta voando com altos ângulos de ataque (variações de $3^{\circ}$ a $47^{\circ}$ ). Várias manobras foram realizadas e analisadas. $O$ objetivo principal deste trabalho foi a obtenção das derivadas de estabilidade lateral-direcional e de controle. Estas foram estimadas e comparadas com valores encontrados em testes feitos em túnel de vento e com resultados obtidos em vôo. As predições de momento de guinada e força lateral devido à guinada exibiram bons resultados quando comparados aos obtidos em túnel de vento, capturando corretamente a tendência de variação com relação a variação de ângulo de ataque. As derivadas de controle estimadas para força lateral e as devido a ação do leme também foram coerentes. Já as derivadas de rotação exibiram resultados pobres quando comparadas aos resultados preditos em túnel de vento, devido a alta correlação existente entre as superfícies de entrada de controle. Os resultados obtidos foram plotados em gráficos e estes mostravam o intervalo de tolerância de erro para cada uma das derivadas.

MORELLI (1999) apresentou um método para estimação de parâmetros usando o erro de equação no domínio da freqüência e a transformada de Fourier para a análise de dados em tempo real. Para demonstrar que a técnica produz bons resultados, foram apresentados exemplos simulados lineares e não lineares usando dados de vôo do F-18. Concluiu-se que o método requer baixa exigência computacional, filtra automaticamente o ruído e pode ser implementado a bordo.

Em TISCHLER (1995) e MORELLI (1999) podem ser encontrados métodos de identificação de parâmetros no domínio da freqüência que foram aplicados com sucesso.

MORELLI (2002) apresentou uma coleção de programas para identificação de aeronaves. Os programas chamados SIDPAC (IDentification Programs for AirCraft) foram desenvolvidos em ambiente MATLAB ${ }^{\circledR}$ e no trabalho foram apresentadas todas as rotinas. O pacote de programas tem sido usado com sucesso no centro de pesquisas NASA Langley com dados de muitos ensaios em vôo e dados conseguidos em túnel de vento. O pacote inclui rotinas para desenvolvimento de experimentos, análise de compatibilidade de dados, estimação de parâmetros através do método erro de equação do e erro de saída, ambos no domínio do tempo e da freqüência, estimação de 
parâmetros em tempo real, simulação linear e não linear e visualização em três dimensões. Este trabalho fornece ao leitor uma ótima base sobre os vários tipos de problemas envolvidos em identificação de sistemas na área de aeronáutica e uma rica revisão bibliográfica neste assunto.

JATEGAONKAR et al. (2003) abordaram métodos e critérios de estimação de parâmetros em aeronaves. Forneceram uma visão geral de algumas atividades de identificação de sistemas realizadas durante a última década em um centro aeroespacial alemão. Depois de uma breve revisão dos métodos de estimação de parâmetros e de verificar a consistência de dados de vôo disponíveis, uma ênfase foi dada no desenvolvimento de bases de dados aerodinâmicos para treinamento em simuladores e como modelá-los para serem colocados a bordo. Foram apresentados também validações de modelos aerodinâmicos de aviões e um modelo paramétrico de resposta de helicóptero. Estes exemplos envolveram uma variedade de veículos com características extensamente diferentes. Além dos aspectos de estimação de parâmetros, foram discutidos também aqueles relacionados com validação de modelos. Através de exemplos, mostrou-se que identificação de sistemas transformou-se uma ferramenta indispensável não somente na pesquisa, mas também nas atividades de indústria tais como validação de modelos, avaliação de qualidade, projetos de leis do controle e projeto e certificação de veículo de vôo, contribuindo assim significativamente com redução de risco de acidentes e redução de custo.

MENDONÇA \& GÓES (2003) aplicaram um método no domínio da freqüência, o método de erro de resposta em frequência, para identificar parâmetros de um modelo linear da dinâmica longitudinal de uma aeronave regional da Embraer. Foram usados dados de entrada da manobra "3-2-1-1" e identificados o ângulo de ataque da aeronave, a aceleração da aeronave e a velocidade de arfagem. A suposição de um modelo linear mostrou ser razoável, já que os resultados do modelo e os dados do teste em vôo se apresentaram coerentes.

TOSTES \& GÓES (2003) utilizaram um modelo dinâmico de uma aeronave de asa fixa para gerar dados de vôo e identificar os modos longitudinal e lateral-direcional desta usando técnicas de subespaço. Através da aplicação de rotinas, procurou-se determinar a freqüência natural $\omega_{n}$ e a razão de amortecimento $\zeta$ dos modos dinâmicos associados ao movimento longitudinal e lateral-direcional da aeronave de referência. No caso do movimento longitudinal, simulou-se uma manobra de curto-período, enquanto que no caso lateral-direcional foi simulada uma manobra do tipo 'dutch roll'. Foram apresentados no trabalho todos os dados geométricos e as derivadas aerodinâmicas necessárias à simulação da aeronave. Além disso, foi mostrado que os resultados estimados além de reproduzirem com grande exatidão os parâmetros modais do modelo 
de referência, são também capazes de reproduzir a evolução do comportamento dinâmico do sistema para a dinâmica longitudinal e para a dinâmica lateral-direcional. Destaca-se que REBOLHO et al. (2006) usaram os dados apresentados neste artigo, para simular as respostas da aeronave e calcular a freqüência natural e fator de amortecimento e os resultados foram bastante próximos aos apresentados no trabalho.

MACIEL et al. (2007) apresentaram uma técnica de identificação paramétrica baseada no método Output Error com critério de estimação por máxima verossimilhança e algoritmo de otimização de Levenberg-Marquardt. A técnica foi aplicada a dados de ensaio em vôo de uma aeronave militar, o Xavante AT-26, visando a obtenção das derivadas de estabilidade e controle através de processamento de dados obtidos por sensores instalados na aeronave. Quinze manobras dinâmicas, com excitações longitudinais no manche foram analisadas. O método mostrou-se prático e os resultados obtidos foram bastante satisfatórios.

\subsubsection{Estimação de parâmetros usando redes neurais artificiais}

Segundo CURVO (2002) um bom processo de identificação deve ser capaz de produzir um modelo preciso o suficiente sem nenhum conhecimento prévio da dinâmica do sistema (identificação não paramétrica). Entretanto, como no caso de aplicação em aeronaves que são sistemas complexos, o conhecimento prévio de algumas informações, normalmente conseguidas via equações dinâmicas, ensaios em túnel de vento ou em vôo e etc. auxilia e acelera o processo. Estudos recentes mostram que esse campo é um dos mais promissores dentre os que utilizam as redes neurais artificiais. Uma vez treinada para representar a dinâmica de um sistema, a rede neural artificial pode ser utilizada como modelo de referência em esquema indireto, onde o erro de saída é retropropagado e utilizado no ajuste dos parâmetros.

COOPER \& CROWTHER (1999), apresentaram uma abordagem de predição de velocidade de flutter usando redes neurais. Resultados iniciais mostraram-se satisfatórios, porém concluíram que há necessidade de trabalhos adicionais para determinar a robustez do método para simulação de modelos de flutter em grande escala e dados obtidos em vôo atuais. Foi treinada uma rede neural para emular o comportamento dinâmico de uma aeronave durante um teste de vôo convencional, objetivando-se permitir ao engenheiro de teste de vôo poder expandir o envelope de vôo com segurança. Cinco conjuntos consecutivos de valores de amortecimento foram usados para predizer o amortecimento para os três próximos valores de teste. Neste trabalho o modelo foi implementado na forma de uma rede neural com parâmetros livres no modelo representados pela 
forças de conexão na rede. A informação específica do problema foi cedida através dos exemplos usados para treinar a rede. Cinco conjuntos de dados foram produzidos para valores diferentes de rigidez da raiz de asa. Foram usados 3 conjuntos para treinar a rede e 2 conjuntos de dados para verificar a generalização.

RAISINGHANI \& GHOSH (2000) mostraram a aplicação de redes neurais artificiais ao problema de modelagem e estimação de parâmetros para aeronaves aeroelásticas sem necessitar de medidas de deflexões elásticas ou de suas derivadas. Especificamente, foi proposta uma rede neural feedforward associada a dois métodos desenvolvidos chamados de método Zero e método Delta para predizer coeficientes de força e de momento usando simplesmente medidas de variáveis de movimento e controle. Foram encontrados e mostrados no artigo resultados, bastante coerentes para diferentes condições de flexibilidade de aeronaves, deixando clara a aplicabilidade das redes neurais tanto para modelagem quanto para estimação de parâmetros.

ALLEN \& DIBLEY (2003) usaram redes neurais para identificar carregamentos de momento de flexão, cargas da torção e momentos de dobradiça de superfícies de controle da asa ativa do avião aeroelástico (AAW), usando apenas como entradas ângulo de ataque e taxa de rolagem. Modelos precisos das cargas são requeridos para o desenvolvimento das leis do controle projetadas para aumentar o desempenho de rolamento através da torção da asa. As entradas para o modelo incluem dados do avião, acelerações e posições da superfície de controle. Para o treinamento das redes, foi usado o algoritmo Backpropagation com a técnica de otimização de Levenberg-Marquardt. Primeiramente foram treinadas redes usando dados de modelos lineares e depois então foram treinadas com dados de vôo para dados incluindo não linearidades. Foram comparados os resultados fornecidos pelo modelo gerado pelo método de regressão linear com resultados gerados pelas redes neurais. Os resultados apresentados pelas redes neurais para os modelos de cargas e momentos de dobradiça de superfície de controle da asa foram melhores que os resultados apresentados pelo modelo feito com o método de regressão linear. Os dados usados foram conseguidos com Mach 0.90 a uma altura de 15.000 pés. Houve uma redução média de erro de predição das redes neurais de 18,6 por cento quando comparado aos modelos gerados por regressão linear. Este artigo fornece os dados de entrada utilizados, a seleção de parâmetros da entrada, a estrutura, o treinamento, e a validação dos modelos das redes neurais.

NETO et. al. (2005) apresentaram um algoritmo adaptável para treinamento de redes neurais artificiais conhecidas como Functional Link Network aplicadas a problemas de estimação de parâmetros. Para mostrar os resultados da técnica proposta, fizeram um estudo de caso da 
dinâmica longitudinal da aeronave F-16 usando dados de simulação desta, objetivando estimação das derivadas aerodinâmicas. Para a simulação foi usada a modelagem não linear apresentada por STEVENS et al. (1992). Como entradas para a rede foram fornecidos: velocidade aerodinâmica, velocidade de arfagem, variação de ângulo de ataque, deflexão do profundor e ângulo de derrapagem (sideslip). Os resultados obtidos foram bastante satisfatórios e mostraram que este método pode ser aplicado a problemas de identificação e de controle. Concluíram também que este algoritmo pode ser facilmente implementado no computador de bordo de uma aeronave para identificação de suas derivadas em vôo.

\subsection{Organização da Tese}

No seguimento deste Capítulo 1 de Introdução e Revisão Bibliográfica, o Capítulo 2 apresenta uma introdução às redes neurais artificiais multicamadas, com alguns conceitos básicos teóricos que estão envolvidos no trabalho, incluindo o modelo artificial e as principais arquiteturas de redes neurais usadas em problemas de identificação e estimação de parâmetros.

No Capítulo 3 é mostrado o equacionamento completo do modelo matemático representativo de uma aeronave. Este modelo é não linear e foi baseado no apresentado por ETKIN et al. (1996). A representação deste modelo é feita através de um conjunto de 12 equações diferenciais ordinárias, onde a aeronave é tratada como sendo um corpo rígido com 6 graus de liberdade e com um plano longitudinal de simetria. Para simplificar o equacionamento, são desprezados os efeitos de rotação da Terra e os efeitos de forças de propulsão e também a atmosfera é considerada estando em repouso ou como uma massa de ar com velocidade constante.

No Capítulo 4 serão apresentados e discutidos os resultados da simulação da aeronave A4-D, conforme McRUER et al. (1973) e SCHIMIDT (1998) usada no estudo de caso, e os resultados de uma das contribuições deste trabalho: a identificação dos estados da aeronave dentro do envelope de vôo utilizando redes neurais recorrentes.

No Capítulo 5 são apresentados os resultados da segunda contribuição desta Tese: a resolução do problema inverso do mostrado no Capítulo 4. Redes neurais feeforward serão aplicadas a dois problemas: um simulado e um real. A partir das respostas de velocidades e dados da aeronave serão estimadas as derivadas de estabilidade desta usando redes neurais estáticas.

No Capítulo 6 são apresentadas as conclusões e propostas para trabalhos futuros. 


\section{CAPÍTULO 2}

\section{ALGUNS MODELOS DE REDES NEURAIS ARTIFICIAIS}

\subsection{Introdução}

Durante os dez últimos anos, o uso de redes neurais em modelagem de sistemas dinâmicos aumentou significantemente. Isto é justificado pela sua capacidade de processamento em paralelo, capacidade de aproximação de funções, capacidade de aprendizagem e facilidade de implementação. Sua capacidade de identificação de não linearidades tem contribuído muito em muitas áreas. Dentre as principais áreas de aplicação de redes neurais artificiais estão identificação de sistemas, controle de sistemas e aproximação de funções.

Neste capítulo serão apresentados os aspectos teóricos de redes neurais artificiais, incluindo o modelo do neurônio artificial e as principais arquiteturas de redes neurais usadas em problemas de identificação e estimação de parâmetros. Será apresentada também uma base teórica do funcionamento do treinamento supervisionado. Destaca-se que neste trabalho foi usado o algoritmo backpropagation com a técnica de otimização de Levenberg-Marquardt para o treinamento das redes, mas a teoria destes métodos não será detalhada nesta tese pois é facilmente encontrada na literatura.

\subsection{Redes Neurais artificiais}

Redes Neurais são técnicas computacionais que apresentam um modelo matemático inspirado na estrutura neuronal de organismos inteligentes e que adquirem conhecimento através 
da experiência. Ou seja, pode-se definir uma rede neural artificial como sendo um sistema de processamento de dados com um grande número de neurônios artificiais (CRIVELARO, 2004).

As redes neurais artificiais podem ser utilizadas na resolução de uma grande classe de problemas encontrados em várias áreas aplicadas: classificação, aproximação, identificação, diagnóstico, análise de sinais e de imagens, otimização e controle. As Redes Neurais têm-se mostrado de fácil implementação, robustas no tratamento de dados com ruído e eficientes, especialmente nos problemas em que não se tem formulação analítica ou não se tem um conhecimento explícito acessível ou os dados que possuem ruídos ou o próprio problema modifica-se com o tempo. O emprego de uma rede neural depende da habilidade em adaptá-la ao problema considerado, por meio de mudanças nos pesos sinápticos (aprendizagem), de modo a aumentar sua eficiência.

\subsection{Modelo de um neurônio}

Um neurônio é a unidade fundamental de processamento de informação de uma rede neural (HAYKIN, 1994), e a Figura 2.1 mostra um modelo de neurônio artificial proposto por McCulloch e Pitts (1943). Podem ser identificados três elementos básicos no modelo:

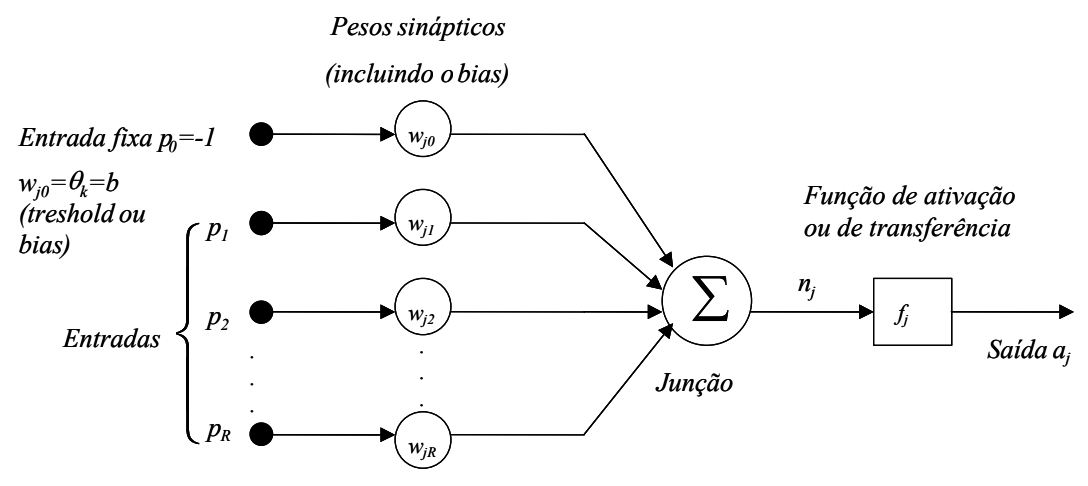

Figura 2.1 - Modelo de um neurônio (HAYKIN, 1994).

1. Um conjunto de sinapses ou conexões de entrada, sendo cada entrada ponderada por um peso sináptico. Portanto, um sinal $p_{k}$ na entrada ponderada ao neurônio $j$ é multiplicado pelo seu peso sináptico $w_{j k}$. A ordem adotada para os índices se refere primeiramente ao neurônio em questão e o segundo índice ao terminal de entrada da sinapse ao qual o peso se refere. 
2. Uma junção (soma), responsável pela soma dos sinais de entrada, ponderados pelos respectivos pesos das sinapses do neurônio.

3. Uma função de ativação ou de transferência, geralmente não linear, para expressar a atividade deste neurônio, ou seja, se está ativado ou não. Tipicamente, a função de ativação do neurônio é limitada ao intervalo $[0,1]$ ou $[-1,1]$.

A saída $a$ do neurônio é calculada como

$a=f(\mathbf{w p}+\mathbf{b})$

onde $f$ é uma função de transferência ou função de ativação do neurônio, $\mathbf{p}$ é o vetor de entradas da rede, $\mathbf{w}$ é o vetor peso que pondera cada elemento da entrada $\mathbf{p}$ e $\mathbf{b}$ é vetor formado pelos bias, que são os pesos relativos à entrada fixa.

Uma vez escolhida a função de ativação, os valores dos pesos e do bias podem ser ajustados de forma a obter uma relação satisfatória entrada/saída. Há vários tipos de função de ativação e sua escolha é baseada na tarefa que o neurônio irá executar. Entre as funções de ativação pode-se citar: degrau, rampa e sigmóides.

\subsubsection{Tipos de Função de Ativação}

A função de ativação define a saída do neurônio em termos do seu nível de ativação interna. Podem ser identificadas três classes principais de função de ativação (IYODA, 2000):

1. Função Degrau. Para este tipo de função, mostrada na Figura 2.2 tem-se:

$$
a= \begin{cases}1 & \text { se } n \geq 0 \\ 0 & \text { se } n<0\end{cases}
$$




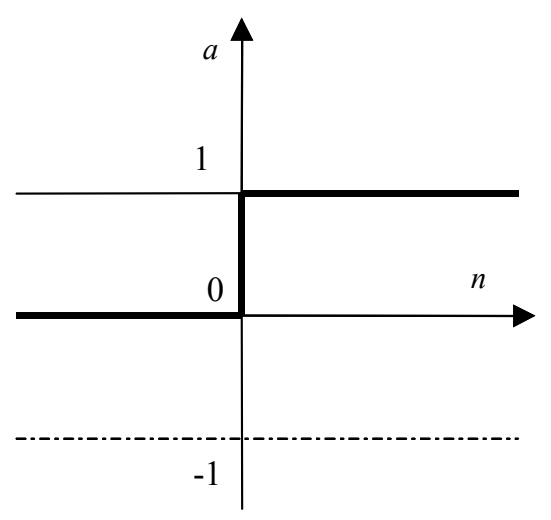

Figura 2.2 - Função Degrau.

2. Função Linear por Partes. Para a função linear por partes, mostrada na Figura 2.3, tem-se:

$$
a=\left\{\begin{array}{cc}
-1, & \text { se } n \leq-b \\
n / b, & \text { se }-b<n<b \\
1, & \text { se } \quad n \geq b
\end{array}\right.
$$

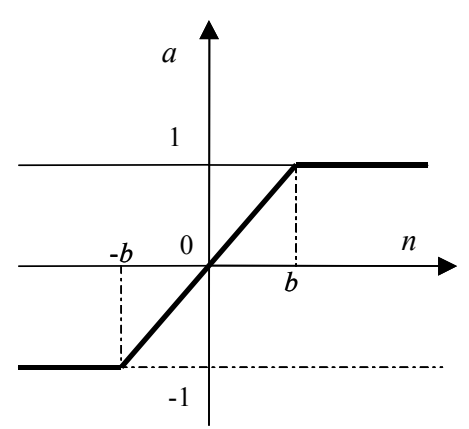

Figura 2.3 - Função linear por partes

3. Função Sigmoide. É a função mais utilizada em redes neurais multicamadas que são treinadas com o algoritmo backpropagation. Ela é definida como uma função monotônica crescente que apresenta propriedades assintóticas e de suavidade. Um exemplo de função sigmoide é a chamada função logística. A função é definida por

$$
a(n)=\frac{a}{1+e^{-\alpha n}}
$$

e é mostrada na Figura 2.4: 


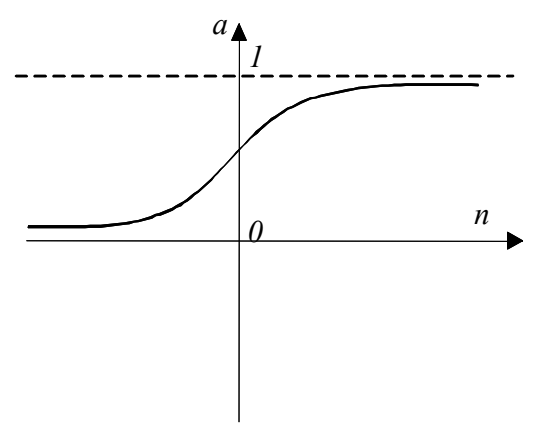

Figura 2.4 - Função logística.

O parâmetro $\alpha$ é o parâmetro de inclinação da função sigmoide, portanto, quando varia, podemos obter funções sigmoides com diferentes inclinações. Em muitas situações, é desejável que a função sigmoide varie entre -1 e 1 , e neste caso, a função normalmente empregada é a tangente hiperbólica, dada por:

$a(n)=\operatorname{tgh}\left(\frac{n}{2}\right)=\frac{1-e^{-n}}{1+e^{-n}}$

As funções de transferência que foram usadas neste trabalho são: função não linear tangente hiperbólica como a apresentada e a função linear, cujos gráficos estão apresentados a seguir nas Figuras 2.5 e 2.6.

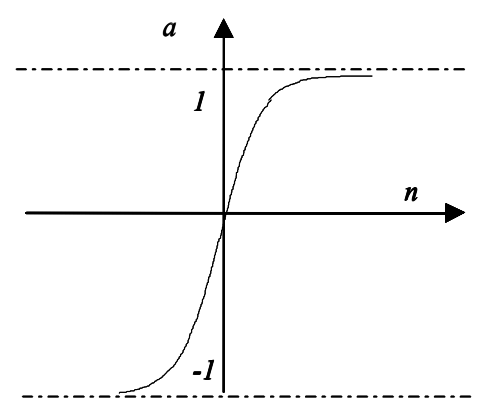

Figura 2.5 - Função tangente hiperbólica. 


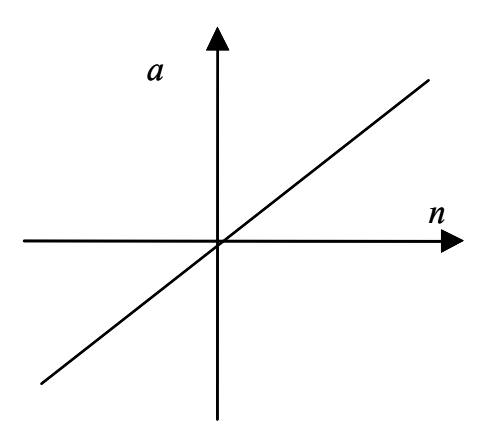

Figura 2.6 - Função linear.

As funções lineares são geralmente usadas nos neurônios que compõem a última camada de uma rede neural e as funções sigmóides são as mais usadas nos neurônios das camadas intermediárias (FERREIRA, 2005).

Em grande parte dos problemas é necessária a normalização dos dados, já que as funções de ativação são normalmente limitadas superior e inferiormente.

\subsubsection{Normalização dos Dados}

O treinamento de uma rede neural artificial pode ser mais eficiente se determinadas etapas de pré-processamento dos dados de entrada e saída desejada forem executadas. Uma etapa bastante importante é a de normalização dos dados. Isto se deve ao fato de que, como dito anteriormente, as funções de ativação dos neurônios normalmente são limitadas inferior e superiormente. Ou seja, se não for realizada a normalização e os dados não estiverem entre os valores máximo e mínimo da função, estes já entram saturados na rede, não ativando os neurônios e assim não sendo processados. Há várias formas de se normalizar os dados, como a Normalização através da Média e do Desvio Padrão e Análise do Componente Principal, mas será feita apenas uma breve descrição da utilizada neste trabalho que foi a divisão pelo máximo valor absoluto.

\subsubsection{Normalização através da Divisão pelo Valor Máximo Absoluto}

Neste trabalho, foi utilizado este tipo de normalização, que neste caso, é realizada dividindo-se cada elemento das matrizes de entrada e saída pelo máximo valor absoluto de cada linha das matrizes. Portanto, as entradas e saídas desejadas normalizadas, possuem valores no intervalo [- 1,1]. Logo, as saídas da rede corresponderão às saídas desejadas normalizadas, tornando-se necessária a conversão para as mesmas escalas usadas para as saídas originais. Para 
isto é necessário que multipliquem-se cada uma das linhas da matriz pelo valor máximo absoluto, obtendo-se, portanto, saídas não-normalizadas que serão comparadas às saídas desejadas, fornecidas originalmente à rede neural.

\subsection{Redes Neurais Multicamadas}

Uma rede neural artificial multicamadas é um sistema de neurônios ligados por conexões sinápticas, dividida em neurônios de entrada, que recebem estímulos do meio externo, neurônios intermediários ou ocultos e neurônios de saída, que se comunicam com o exterior. São arquiteturas onde os neurônios são organizados em duas ou mais camadas de processamento, já que existirão pelo menos uma camada de entrada e uma camada de saída. A propagação do sinal de entrada pode se dar apenas num único sentido, sendo da camada de entrada para a camada de saída ou podem haver laços de realimentação fazendo com que o sinal se propague da entrada para a saída e retorne, para neurônios da camada de entrada ou para neurônios das camadas intermediárias.

O número de entradas e o número de saídas da rede são definidos de acordo com o problema específico. As características desejadas para as saídas da rede podem também ajudar a selecionar a função de ativação para a camada de saída. Se uma saída deve assumir os valores 0 ou 1, então a função de ativação degrau deve ser usada. Assim, a arquitetura de uma rede neural de camada simples é quase completamente determinada por problemas específicos, incluindo um número determinado de entradas e saídas e as características particulares da saída desejada.

\subsubsection{Redes Neurais Multicamadas feedforward}

Uma arquitetura de rede neural multicamadas feedforward (RUMELHART, 1986) consiste de uma camada de entrada, que é assumida ter neurônios com função de ativação linear, uma camada de saída e uma ou mais camadas intermediárias de neurônios, que não são nem de entrada e nem de saída. Os neurônios das camadas intermediárias são assumidos serem não lineares como dito anteriormente. Não linearidades normalmente incluem: função sigmoide, função tangente hiperbólica, função de base radial, etc. Uma das maiores razões pelas quais estas redes são muito populares, é que sua arquitetura é um aproximador universal, para mapeamentos estáticos não lineares gerais, contanto que um número de neurônios suficiente esteja sendo usado na camada intermediária (TSOI, 1998). 
Numa rede neural multicamadas, cada camada tem sua própria matriz peso $\mathbf{W}$, seu próprio vetor bias $\mathbf{b}$, um vetor de entrada $\mathbf{n}$ na função de ativação $f$ e um vetor de saída $\mathbf{a}$. Para distinguir entre cada uma delas usar-se-á índices sobrescritos. Assim, a matriz peso para a primeira camada é escrita como $\mathbf{W}^{1}$ e a matriz peso para a segunda camada é escrita como $\mathbf{W}^{2}$. Esta notação é usada até a última camada da rede como mostra o exemplo na Figura 2.7.

Pode-se observar também que as saídas das primeira e segunda camadas são respectivamente as entradas da segunda e terceira camadas, ou seja, o sinal de entrada se propaga da camada de entrada para a camada de saída mas não vice-versa. Em outras palavras, esta rede neural é estritamente do tipo feedforward. Assim, a segunda camada pode ser vista como uma rede com uma camada com $R=S^{l}$ entradas, $S=S^{2}$ neurônios e uma $S^{\prime} \times S^{2}$ matriz peso $\mathbf{W}^{2}$. A entrada para a segunda camada é $\mathbf{a}^{\mathbf{1}}$ e a saída é $\mathbf{a}^{2}$.

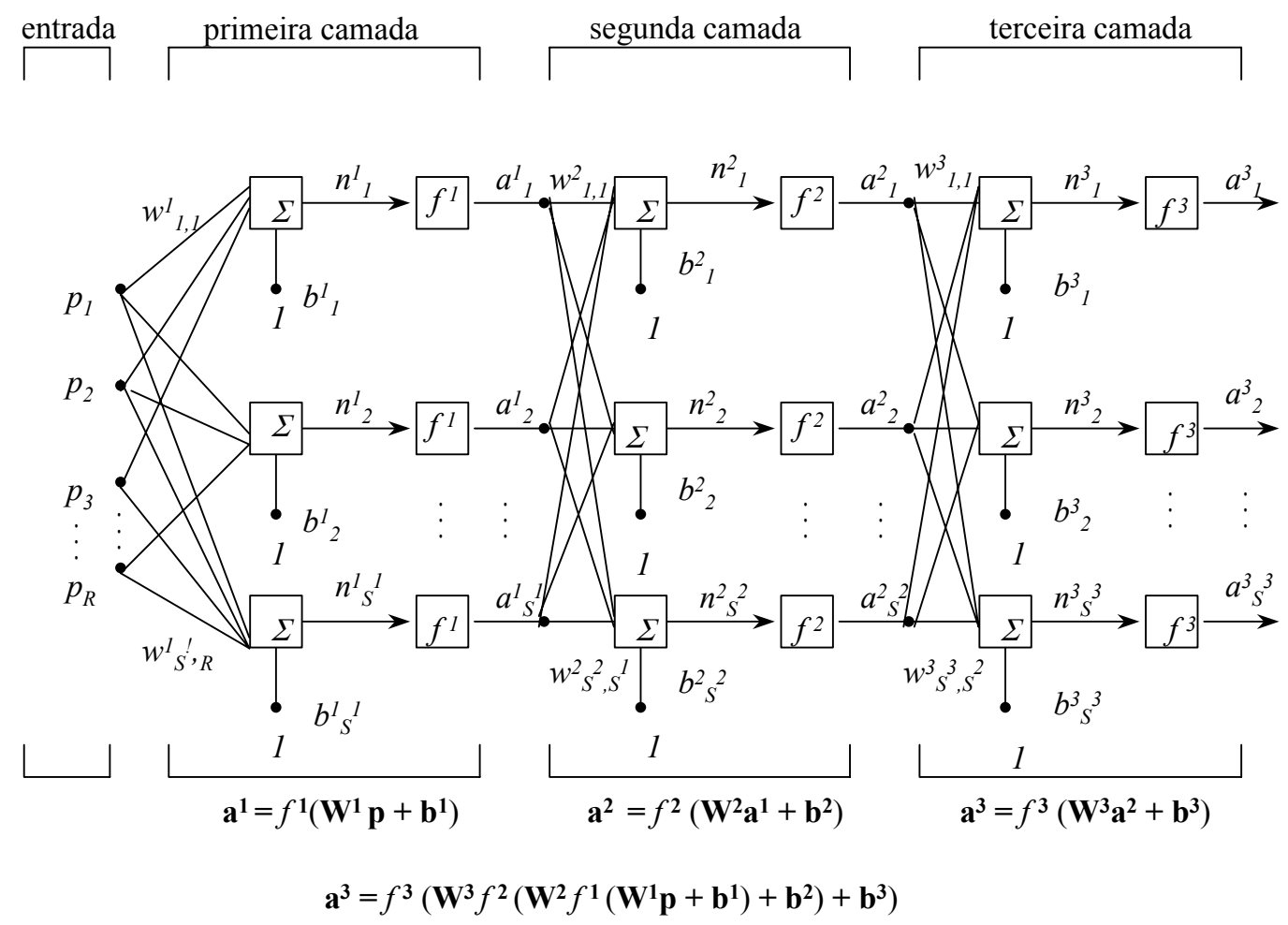

Figura 2.7 - Rede com três camadas (HAGAN et al., 1996).

\subsubsection{Redes Neurais Recorrentes}

Redes recorrentes são redes neurais com um ou mais laços de realimentação, que pode ser de natureza local ou global, ou seja, são usadas ambas conexões no sentido da entrada para saída como também laços de realimentação (KLING, 2003). O uso de realimentação permite que 
as redes recorrentes adquiram representações de estado, o que as tornam dispositivos apropriados para diversas aplicações dinâmicas como: previsão ou modelagem de sistemas não lineares, equalização adaptativa de canais de comunicação, controle de instalações industriais, diagnósticos de motores automotivos e processamento de sinais temporais como o sinal de voz (HAYKIN, 1994).

Como nas redes neurais feedforward multicamadas, as redes neurais recorrentes também podem mapear qualquer sistema não linear dinâmico. A diferença é que a resposta da rede recorrente é função da entrada externa no tempo corrente, seus atrasos e saídas atrasadas também. Ou seja, a saída da rede recorrente é dada pela Eq. (2.4):

$$
y(k)=f(u(k), u(k-1), \ldots, u(k-M), y(k-1), y(k-2), \ldots, y(k-N))
$$

Enquanto há somente uma arquitetura geral de perceptron multicamadas (MLP), há um número considerável de arquiteturas de redes neurais recorrentes (RNN) que tem sido propostas por vários grupos de pesquisadores (TSOI, 1998).

As Redes Neurais com atrasos no tempo são um caso particular de redes neurais recorrentes (MARQUES et al., 2005). A resposta destas redes no tempo $t$ é baseada nas entradas nos tempos $(t-1),(t-2), \ldots,(t-n) . O$ mapeamento feito por uma rede neural com atrasos no tempo produz uma saída para o tempo $k$ como mostra a Eq. (2.5):

$$
y(k)=f(u(k), u(k-1), \ldots, u(k-M))
$$

onde $u(k)$ é a entrada para o tempo $\mathrm{k}$ e M é o número máximo de atrasos no tempo. A Figura 2.8 a seguir mostra um esquema deste tipo de rede neural. 


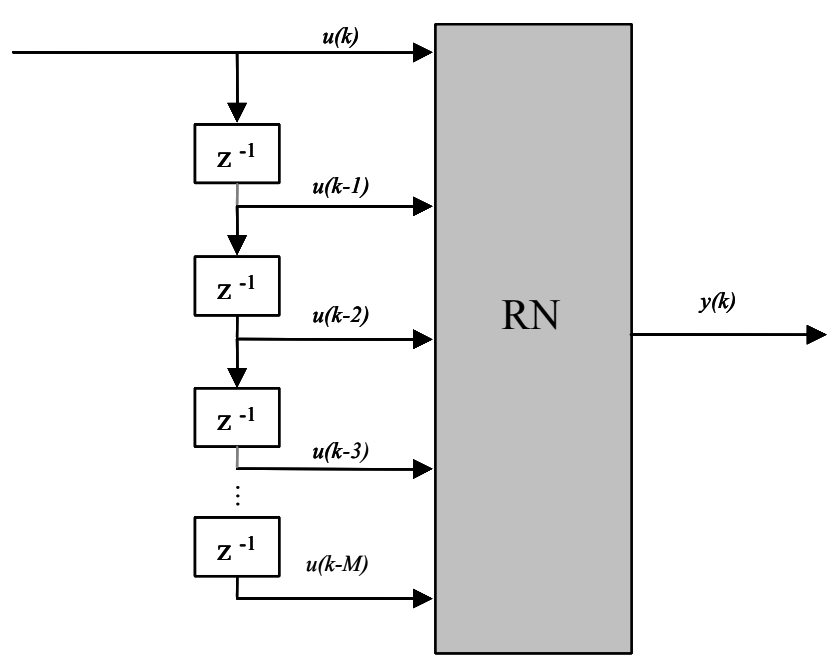

Figura 2.8 - Rede com atrasos no tempo.

Depois de devidamente treinadas, estas redes têm sido usadas com sucesso em problemas de predição, pois são capazes de capturar a dinâmica do sistema e predizer a saída para o tempo corrente. DE MARQUI et al. (2004) utilizaram uma rede deste tipo para estimação de velocidade de flutter.

Devido aos efeitos benéficos da realimentação, as redes neurais recorrentes apresentar melhores resultados nas aplicações dinâmicas quando comparadas às redes com atraso no tempo sem realimentação, descritas na seção anterior. Este fato ocorre, pois o uso da realimentação tem o potencial de reduzir significativamente as exigências de memória.

\subsubsection{Redes Neurais NARX}

A rede NARX (Non-linear Autoregressive with Exogenous Inputs) é referida como um modelo autoregressivo não linear com entradas externas (LIN et al., 1996). Neste modelo de rede recorrente o sinal de realimentação da saída é atrasado de $M_{r}$ vezes enquanto que o sinal de entrada apresenta $M_{e}$ atrasos. Os atrasos de entrada e realimentação podem ser iguais ou não, ou seja, explicam o valor da saída em função dos valores prévios de entrada e saída.

A Figura (2.9) ilustra este modelo de rede com uma camada intermediária. É interessante salientar que este modelo permite o uso de mais de uma camada intermediária. A saída de uma rede NARX é uma função da entrada externa atual juntamente com suas $M_{e}$ entradas anteriores e das $M_{r}$ saídas anteriores da rede como se pode observar pela Equação (2.6). 
$y(k+1)=F\left(y(k), \ldots, y\left(k-M_{r}\right), u(k), \ldots, u\left(k-M_{e}\right)\right)$

O modelo NARX abrange uma classe importante de sistemas não lineares de tempo discreto (LEONTARITIS \& BILLINGS, 1985). No contexto das redes neurais este modelo é discutido em CHEN et al. (1990), NARENDRA \& PARTASARATHY (1990), LIN et al. (1996) e SIEGLEMANN et al. (1997).

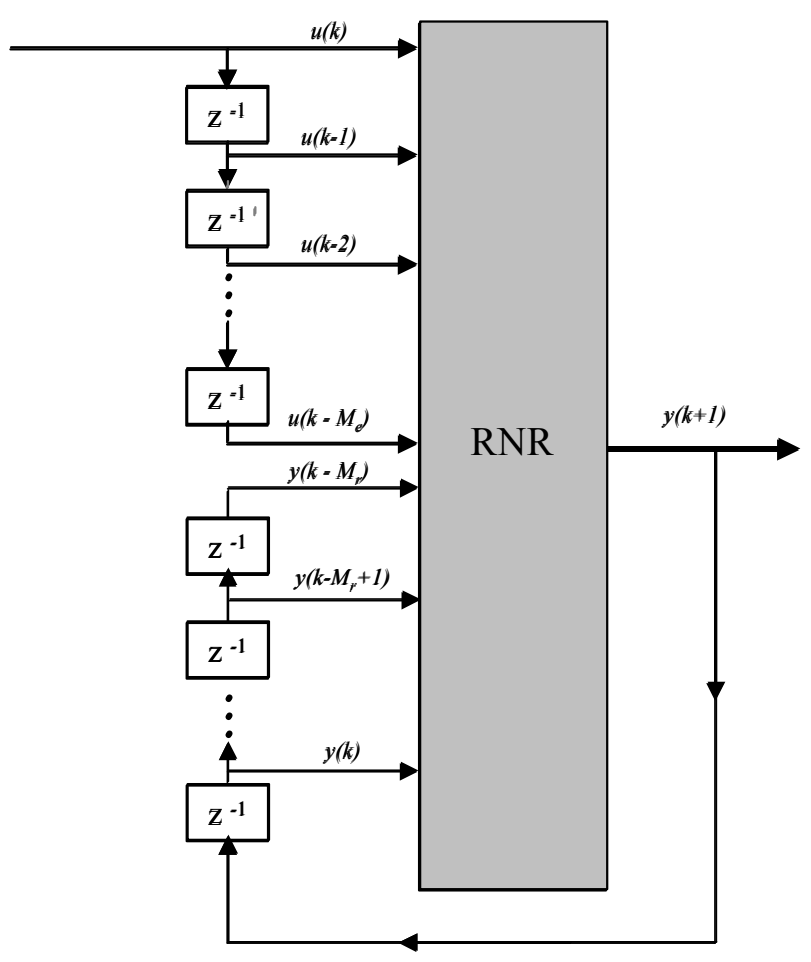

Figura 2.9. Rede NARX.

O modelo NARX, como pode-se observar, possui laços de realimentação e também atrasos no tempo.

\subsection{Aprendizagem de uma rede neural}

Entre as diversas propriedades importantes de uma rede neural, a propriedade mais atraente em problemas de identificação é a capacidade da rede em aprender sobre o seu meio ambiente e melhorar seu desempenho através de aprendizado. Uma rede neural aprende sobre o seu meio ambiente através de um processo iterativo de ajuste aplicado aos seus pesos e bias. Idealmente, a rede vem a conhecer mais sobre o seu meio ambiente depois de cada iteração do processo de aprendizagem. 
O processo de aprendizagem, definido no contexto de redes neurais, é um processo pelo qual seus pesos são adaptados através de um processo contínuo de simulações no meio ambiente em que a rede está inserida. Existem muitos tipos de regras de aprendizado de redes neurais (HAYKIN, 1994). Elas dividem-se em três grandes paradigmas: aprendizado supervisionado, aprendizado não supervisionado e aprendizado por reforço. Neste trabalho serão discutidos apenas o aprendizado supervisionado e o não supervisionado, pois foram os dois tipos utilizados.

\subsubsection{Aprendizado Supervisionado}

Este tipo de aprendizagem é caracterizado pela presença de um 'professor' externo, cuja função é suprir a rede com a resposta desejada a um determinado estímulo. Define-se erro como a diferença entre a resposta desejada e a resposta observada. A seguir é mostrado um esquema que representa um sistema com aprendizado supervisionado. Ou seja, para uma rede neural com entradas e saídas denotadas respectivamente por $\mathbf{p}$ e $\mathbf{t}$, onde $\mathbf{p}$ representa um vetor de entrada e $\mathbf{t}$ um vetor com as saídas desejadas, é fornecido o seguinte conjunto de treinamento:

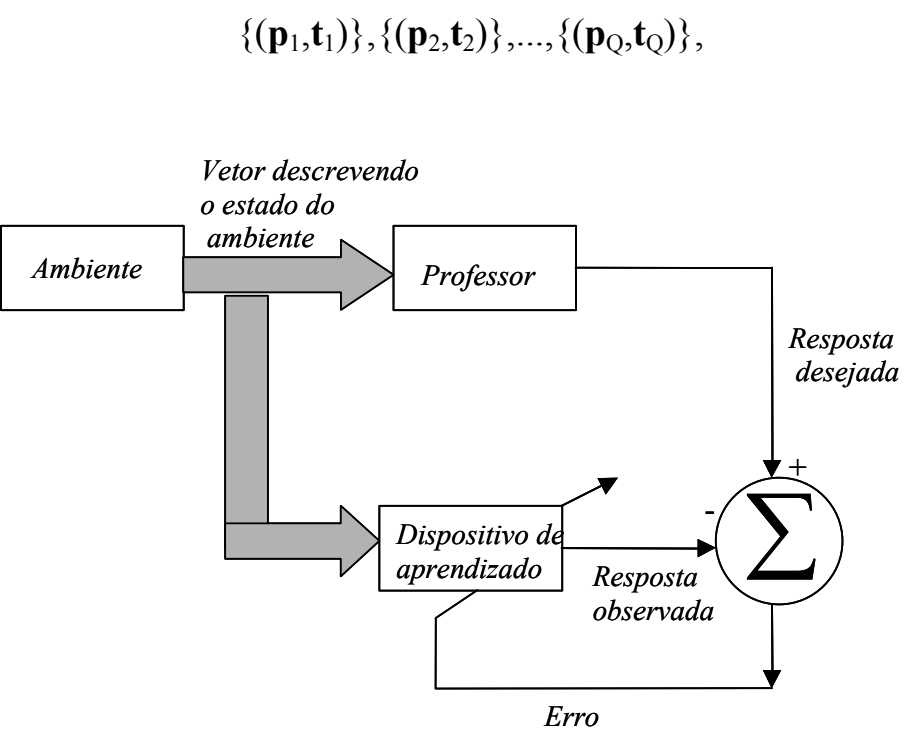

Figura 2.10 - Diagrama de blocos que representa um sistema com aprendizado supervisionado.

As redes neurais multicamadas feedforward e recorrentes usam o processo de treinamento supervisionado e o algoritmo mais popularmente usado é o algoritmo Backpropagation para treiná-las. Neste trabalho optou-se por utilizar este algoritmo com a técnica de otimização de Levenberg-Marquardt, que é uma variação do método de Newton que foi designado para minimizar funções que são soma dos quadrados de outras funções não lineares. Este método é muito importante no treinamento de redes neurais e seu índice do desempenho é 
dado como erro quadrático médio (HAGAN et al., 1996). FERREIRA (2005) programou o algoritmo todo e, em sua dissertação de mestrado encontra-se o algoritmo descrito passo-a-passo. Em SOUZA (2002) e CRIVELARO (2000) também encontra-se descrito detalhadamente este algoritmo.

\subsubsection{Aprendizado não Supervisionado}

$\mathrm{Na}$ aprendizagem não supervisionada ou auto-organizada, não há supervisão do processo de aprendizado. Uma vez que a rede tenha se ajustado às regularidades estatísticas dos dados de entrada, ela desenvolve a habilidade de formar representações internas para codificar as características da entrada e, desse modo, criar automaticamente novas classes (BECKER apud HAYKIN, 1996).

Os algoritmos de aprendizado não supervisionado são geralmente baseados em uma forma de competição entre os neurônios. O método mais comum é chamado de aprendizado competitivo. O aprendizado competitivo é uma forma de aprendizado que divide o conjunto de padrões de entrada em grupos inerentes aos dados. Neste aprendizado não existe conhecimento a respeito da classe a que o padrão pertence, depende das entradas e de suas densidades de probabilidade, precisa de um grande conjunto de dados (redundância) para adquirir conhecimento das propriedades estatísticas dos padrões e tem uma dependência do histórico de apresentação dos padrões.

É essa característica que torna a aprendizagem competitiva mais adequada para descobrir características estaticamente salientes que podem ser usadas para classificar um conjunto de padrões de entrada.

\subsection{Conclusão}

Neste capítulo foram apresentados os aspectos teóricos de redes neurais artificiais, incluindo o modelo do neurônio e as principais arquiteturas de redes neurais usadas em problemas de identificação. Foram apenas citados os tipos de aprendizado. Não foram descritos os algoritmos de treinamento, no caso, backpropagation e o algoritmo de Levenberg-Marquardt, pois estes podem ser encontrados facilmente, como citado neste Capítulo, e por ter sido usado o pacote do Matlab $^{\circledR}$. Destaca-se que este capítulo é bastante importante para os outros capítulos do trabalho e fornece ao leitor uma base teórica em redes neurais. 


\section{CAPÍTULO 3}

\section{AS EQUAÇÕES DE MOVIMENTO}

\subsection{Introdução}

O modelo matemático de uma aeronave em vôo e de seus subsistemas é essencial para análise, cálculos ou simulação do movimento desta. Uma aeronave em vôo é um sistema dinâmico muito complexo, pois envolve um agregado de movimentos relativos a corpos rígidos e corpos elásticos. Este fato faz com que haja a necessidade dos modelos desenvolvidos serem bastante precisos e realistas, para possibilitar aos engenheiros uma análise perfeita do modelo (ETKIN \& REID, 1996).

Neste capítulo será apresentado o equacionamento completo do movimento de uma aeronave, entretanto, considerando-a ainda um corpo rígido. Este modelo matemático é não linear e foi apresentado por ETKIN \& REID (1996). Será implementado usando o pacote Simulink ${ }^{\circledR}$ e, apesar de ser bastante simplificado, apresenta resultados bastante coerentes e próximos do real. A representação deste sistema é feita através de um conjunto de 12 equações diferenciais ordinárias, onde a aeronave é tratada como sendo um corpo rígido com 6 graus de liberdade e com um plano longitudinal de simetria, sob o efeito das forças aerodinâmicas e da gravidade. Para simplificar o equacionamento, também serão desprezados os efeitos de rotação da Terra e os efeitos de forças de propulsão e a atmosfera estando em repouso. 


\subsection{Equações gerais de movimento não estacionário}

Como dito anteriormente, a aeronave será tratada como um corpo rígido com seis graus de liberdade, sendo três para movimento de translação e três para rotação, podendo se mover livremente, mas sofrendo o efeito das forças aerodinâmicas propulsivas e da gravidade. Serão desprezados os efeitos de rotação da Terra e esta será considerada plana e estacionária no espaço. Serão consideradas também a massa e a inércia da aeronave constantes, pois o intervalo de tempo da simulação é razoavelmente pequeno. Será adotado também o plano $x z$ de simetria fazendo com que, $I_{z y}=I_{y z}=I_{x y}=I_{y x}=0$. Neste capítulo serão apresentados os momentos aerodinâmicos e as forças que aparecem nas equações de movimento.

\subsection{Equações de corpo rígido}

As equações de corpo rígido são encontradas aplicando as leis de Newton a um elemento de massa $d m$ da aeronave e então integradas para todos os outros elementos. Serão adotados dois sistemas de referências: um sistema de referência fixo no corpo e um sistema de referência fixo na Terra, sendo que as equações do movimento podem ser escritas em qualquer um destes sistemas, e a escolha depende da conveniência (CURVO, 2001). Para este trabalho, também serão usados estes dois sistemas de coordenadas.

O primeiro sistema de referência, denotado por $F_{E}\left(O_{E}, x_{E}, y_{E}, z_{E}\right)$, está fixo na Terra e a localização do $C G$ da aeronave é dada de acordo as Coordenadas Cartesianas deste sistema. As forças aerodinâmicas dependem da velocidade relativa a $F_{E}$ e da massa de ar em relação ã aeronave.

O segundo ponto de referência necessário para o desenvolvimento das equações de movimento, será denotado por $F_{B}(O, x, y, z)$ e está fixo na aeronave se movendo com ela. Sua origem coincide com o CG da aeronave, ou seja, $O$ é o centro de gravidade da aeronave, $O x$ e $O z$ estão no plano de simetria da aeronave com $O z$ para baixo. 
As velocidades $u$, $v$ e $w$ são definidas como sendo as componentes do vetor de velocidade nos respectivos eixos do sistema de coordenadas $F_{B}(O, x, y, z)$, como mencionado acima fixo na aeronave, e $p, q$ e $r$ as componentes do vetor de rotação também nos respectivos eixos desse mesmo sistema.

Portanto os dois sistemas de referência usados na formulação das equações de movimento serão:

$F_{E}$ : Sistema de referência fixo na Terra;

$F_{B}$ : Sistema de referência fixo na aeronave.

Denotando a velocidade do vento relativa a $F_{E}$ por $\mathbf{W}$ e a velocidade do CG relativa ao ar por $\mathbf{V}$, então a velocidade relativa ao sistema inercial denotada por $\mathbf{V}_{E}$ pode ser dada por:

$$
\mathbf{V}_{E}=\mathbf{V}+\mathbf{W}
$$

Como neste trabalho será desprezada a velocidade do vento, que $\mathbf{W}=0$, a velocidade aerodinâmica será então igual à velocidade inercial como mostra a Equação (3.2) a seguir.

$$
\mathbf{V}_{E}=\mathbf{V}
$$

$\mathrm{O}$ vetor velocidade do ar com relação à aeronave é dado por $\mathbf{V}_{B}$ e como foi assumido $\mathbf{W}=\mathbf{0}$, num ponto em $F_{B}$ tem-se:

$$
\mathbf{V}_{B}=\left[\begin{array}{lll}
u & v & w
\end{array}\right]^{T}
$$

$\mathrm{O}$ vetor posição de $d m$ relativo à origem de $F_{E}$ é $\mathbf{r}_{\mathbf{c}}+\mathbf{r}$, como mostrado na Figura 3.1. Para um ponto de $F_{E}$, tem-se:

$$
\mathbf{r}_{C E}=\left[\begin{array}{lll}
x_{E} & y_{E} & z_{E}
\end{array}\right]^{T}
$$

e num ponto $F_{B}$ tem-se:

$$
\mathbf{r}_{B}=\left[\begin{array}{lll}
x & y & z
\end{array}\right]^{T}
$$




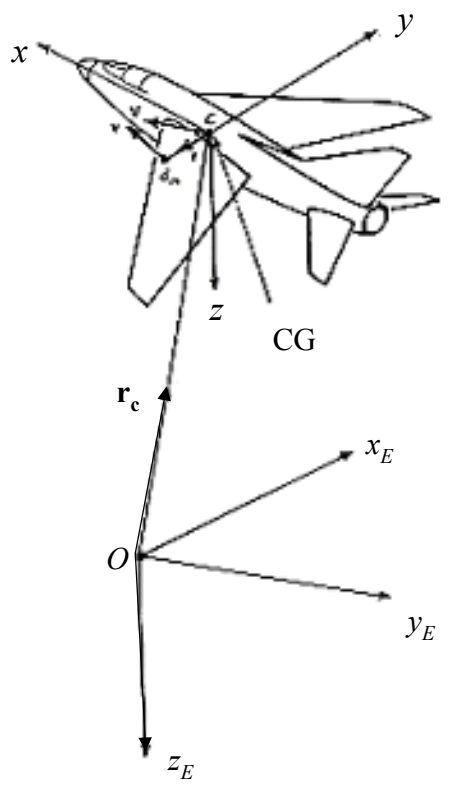

Figura 3.1. Eixos (ETKIN \& REID, 1996).

O vetor velocidade do elemento de massa $d m$ com relação ao sistema de coordenadas inercial é:

$\mathbf{v}_{E}=\left(\dot{\mathbf{r}}_{C E}+\dot{\mathbf{r}}_{E}\right)$

Como $\dot{\mathbf{r}}_{C E}$ é o vetor posição do CG da aeronave relativa ao sistema de coordenadas inercial $F_{E}$ então $\dot{\mathbf{r}}_{C E}=\mathbf{V}_{E}$ e então, $\mathbf{v}_{E}=\left(\mathbf{V}_{E}+\dot{\mathbf{r}}_{E}\right)$.

O momentum de $d m$ é $\mathbf{v} d m$, e portanto para calcular a quantidade de movimento para toda a aeronave, é necessário integrar em todo o corpo da aeronave como mostra a equação (3.7):

$\int \mathbf{v}_{E} d m=\int\left(\mathbf{V}_{E}+\dot{\mathbf{r}}_{E}\right) d m=\mathbf{V}_{E} \int d m+\int \dot{\mathbf{r}}_{E} d m$

Como a aeronave é considerada corpo rígido e como $C$ na Figura 1 é o $C G$ da aeronave, a última integral em (3.7) é zero e, portanto:

$\int \mathbf{v}_{E} d m=m \mathbf{V}_{E}$

onde $m$ é a massa total da aeronave.

Aplicando a segunda Lei de Newton para a massa $d m$, tem-se: 
$d \mathbf{f}_{E}=\dot{\mathbf{v}}_{E} d m$

onde $d \mathbf{f}_{E}$ é a resultante de todas as forças agindo em $d m$. Integrando (3.9) em todo corpo da aeronave, tem-se para a aeronave completa:

$\mathbf{f}_{E}=\int d \mathbf{f}_{E}=\int \dot{\mathbf{v}}_{E} d m$

Usando (3.8),

$\mathbf{f}_{E}=m \dot{\mathbf{V}}_{E}$

O valor da $\int d \mathbf{f}_{E}$ representa a soma de todas as forças que agem sobre todos os elementos da aeronave. Ou seja, $\mathbf{f}_{E}$ é a resultante das forças externas que agem sobre a aeronave, já que as forças internas que são as forças exercidas de um elemento sobre o outro, segundo a terceira lei de Newton todas ocorrem aos pares com valores em módulos iguais e em sentidos opostos, fazendo com que não contribuam em nada na soma.

Para calcular os movimentos de rotação da aeronave, considera-se inicialmente o momentum angular da massa $d m$ com relação ao $C G$, que por definição é $d \mathbf{h}_{E}=\mathbf{r}_{E} \times \mathbf{v}_{E} d m$. Calculando a derivada desta equação, obtém-se:

$$
\frac{d}{d t}\left(d \mathbf{h}_{E}\right)=\dot{\mathbf{r}}_{E} \times \mathbf{v}_{E} d m+\mathbf{r}_{E} \times \dot{\mathbf{v}}_{E} d m
$$

Sendo o momento das forças elementares $d \mathbf{f}$ em torno do $C G d \mathbf{G}=\mathbf{r} \times d \mathbf{f}$ e com (3.9) tem-se que:

$$
d \mathbf{G}_{E}=\mathbf{r}_{E} \times d \mathbf{f}_{E}=\mathbf{r}_{E} \times \dot{\mathbf{v}}_{E} d m
$$

Da Equação (3.12) $\mathbf{r}_{E} \times \dot{\mathbf{v}}_{E} d m=\frac{d}{d t}\left(d h_{E}\right)-\dot{\mathbf{r}}_{E} \times \mathbf{v}_{E} d m$ e da Equação (3.6 a) $\dot{\mathbf{r}}=\mathbf{v}_{E}-\mathbf{V}_{E}$, então tem-se: 
$d \mathbf{G}_{E}=\frac{d}{d t}\left(d \mathbf{h}_{E}\right)-\left(\mathbf{v}_{E}-\mathbf{V}_{E}\right) \times \mathbf{v}_{E} d m$

Como $\mathbf{v} \times \mathbf{v}=0$, ao desenvolver (3.14):

$d \mathbf{G}_{E}=\frac{d}{d t}\left(d \mathbf{h}_{E}\right)+\mathbf{V}_{E} \times \mathbf{v}_{E} d m$

Integrando (3.15), obtém-se para toda a aeronave $\int d \mathbf{G}_{E}=\frac{d}{d t} \int d \mathbf{h}_{E}+\mathbf{V}_{E} \times \int \mathbf{v}_{E} d m$.

Como no CG e para corpo rígido vale $\mathbf{V}_{E} \times \int \mathbf{v}_{E} d m=0$, a Equação torna-se:

$\mathbf{G}_{E}=\dot{\mathbf{h}}_{E}$

onde $\mathbf{h}_{E}=\int \mathbf{r}_{E} \times \mathbf{v}_{E} d m$

Deve-se observar que em (3.16), ambos $\mathbf{G}$ e h se referem ao movimento de um ponto, o Centro de massa (CG do avião). Para o movimento de um outro ponto fora do centro de massa, a equação não é em geral aplicada. Já, as Equações (3.11) e (3.16) juntas são válidas para movimento relativo de outras partes da aeronave.

Portanto, as duas equações de movimento da aeronave, na forma matricial são:

$$
\begin{aligned}
& \mathbf{f}_{E}=m \dot{\mathbf{V}}_{E} \\
& \mathbf{G}_{E}=\dot{\mathbf{h}}_{E}
\end{aligned}
$$

\subsection{Quantidade de movimento angular $h$}

Serão encontradas agora as componentes da quantidade de movimento angular em $\mathbf{F}_{B}$. Sabe-se que $\mathbf{h}=\int d \mathbf{h}=\int \mathbf{r} \times \mathbf{v} d m$, fazendo então com que no sistema fixo à aeronave, ou seja, em $\mathbf{F}_{B}$, seja válido: 
$\mathbf{h}_{B}=\int \mathbf{r}_{B} \times \mathbf{v}_{B} d m$

onde, $\mathbf{r}_{B}=\left[\begin{array}{ccc}0 & -z & y \\ z & 0 & -x \\ -y & x & 0\end{array}\right]$.

Seja a velocidade angular da aeronave relativa a qualquer sistema de referência inercial do espaço definida por $\boldsymbol{\omega}_{B}=\left[\begin{array}{lll}p & q & r\end{array}\right]^{T}$, onde $p, q$ e $r$ são respectivamente velocidades de rotação da aeronave nas direções $X$ (rolagem), $Y$ (arfagem) e $Z$ (guinada) respectivamente, como mostra a Figura 3.2 a seguir.

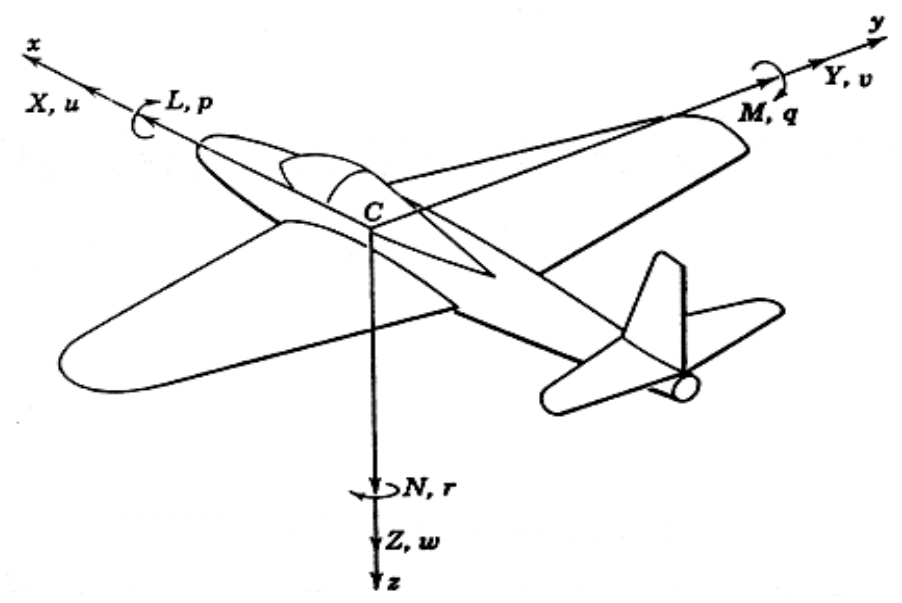

Figura 3.2. Notação para os eixos (ETKIN \& REID, 1996).

Sendo, a velocidade de um ponto qualquer de um corpo rígido dada por $\mathbf{v}_{B}=\mathbf{V}_{B}+\boldsymbol{\omega}_{B} \times \mathbf{r}_{B}$, onde:

$\boldsymbol{\omega}_{\mathbf{B}}=\left[\begin{array}{ccc}0 & -r & q \\ r & 0 & -p \\ -q & p & 0\end{array}\right]$

então, 


$$
\begin{aligned}
& \mathbf{h}_{B}=\int \mathbf{r}_{B} \times\left(\mathbf{V}_{B}+\boldsymbol{\omega}_{B} \times \mathbf{r}_{B}\right) d m= \\
& =\int \mathbf{r}_{B} \times \mathbf{V}_{B} d m+\int \mathbf{r}_{B} \times \boldsymbol{\omega}_{B} \times \mathbf{r}_{B} d m= \\
& =\left(\int \mathbf{r}_{B} d m\right) \times \mathbf{V}_{B}+\int \mathbf{r}_{B} \times \boldsymbol{\omega}_{B} \times \mathbf{r}_{B} d m
\end{aligned}
$$

A primeira integral em (3.20) é nula já que a origem de $\mathbf{r}$ é o CG. Expandindo a matriz produto da segunda integral, o resultado para $\mathbf{h}_{\mathbf{B}}$ encontrado é:

$$
\mathbf{h}_{B}=\mathbf{I}_{B} \boldsymbol{\omega}_{B}
$$

onde $\mathbf{I}_{B}$ é a matriz de inércia e seus elementos são momentos e produtos de inércia da aeronave como mostram as Equações (3.22) e (3.23) a seguir:

$$
\begin{aligned}
& \mathbf{I}_{B}=\left[\begin{array}{ccc}
I_{x} & -I_{x y} & -I_{x z} \\
-I_{y x} & I_{y} & -I_{y z} \\
-I_{z x} & -I_{z y} & I_{z}
\end{array}\right] \\
& I_{x}=\int\left(y^{2}+z^{2}\right) d m \quad I_{x y}=I_{y x}=\int x y d m \\
& I_{y}=\int\left(x^{2}+z^{2}\right) d m \quad I_{x z}=I_{z x}=\int x z d m \\
& I_{z}=\int\left(y^{2}+x^{2}\right) d m \quad I_{y z}=I_{z y}=\int y z d m
\end{aligned}
$$

Vale lembrar que como o plano $x z$ é um plano de simetria, como dito anteriormente, $I_{x y}=I_{y z}=0$.

\subsection{Orientação e posição da aeronave}

A posição da aeronave é dada em relação a um sistema de coordenadas fixo na Terra $F_{E}$. Ou seja, o CG tem vetor posição $\mathbf{r}_{c}$ com coordenadas $\left(x_{E}, y_{E}, z_{E}\right)$ como mostrado na Figura 3.1.

Já a orientação da aeronave é dada pelos ângulos de Euler $(\psi, \theta, \phi)$. São estes ângulos que relacionam o sistema inercial (fixo na Terra) com o sistema de eixos fixos na aeronave. Os 
ângulos de Euler fornecem uma maneira sistemática de descrever a transformação de grandezas no sistema inercial para a aeronave e vice-versa.

\subsubsection{Compondo os ângulos de Euler}

Ângulos de Euler são ângulos usados para fazer o mapeamento de rotação do sistema fixo no corpo para um sistema inercial e vice-versa. Para passar as equações de movimento do sistema inercial para o sistema fixo na aeronave, são aplicadas as seguintes rotações:

1. Uma rotação $\psi$ em torno de $o z_{1}$, levando os eixos para $C_{x_{2} y_{2} z_{2}}$ (eixo $x$ na posição final).

2. Uma rotação $\Theta$ em torno de $o y_{2}$, levando os eixos para $C_{x_{3} y_{3} z_{3}}$ (eixo $y$ na posição final).

3. Uma rotação $\boldsymbol{\Phi}$ em torno de $o x_{3}$, levando os eixos para a posição final $C_{x y z}$.

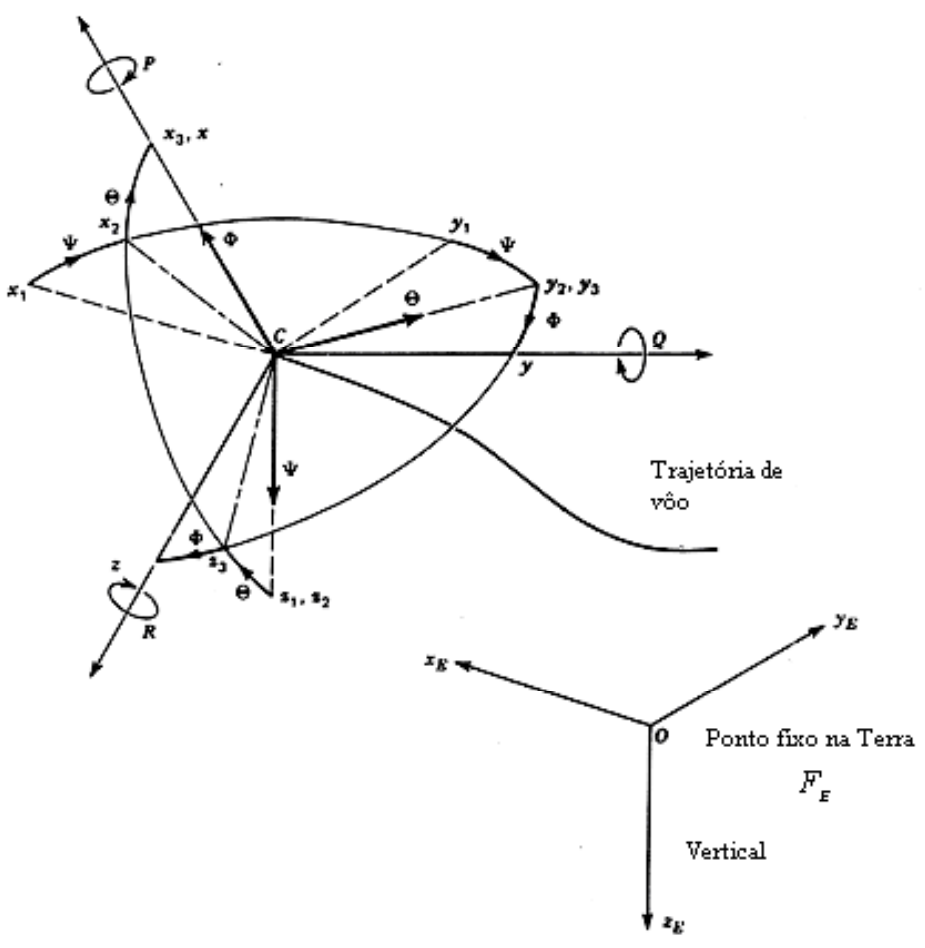

Figura 3.3. Orientação da aeronave (ETKIN \& REID, 1996). 
Os ângulos de Euler são limitados aos intervalos, como segue:

$$
\begin{gathered}
-\pi \leq \psi \leq \pi \quad \text { ou } \quad 0 \leq \psi \leq 2 \pi \\
-\frac{\pi}{2} \leq \theta \leq \frac{\pi}{2} \\
-\pi \leq \phi \leq \pi \text { e } 0 \leq \phi \leq 2 \pi .
\end{gathered}
$$

Estes intervalos mostram que os ângulos de Euler apresentam descontinuidades quando o corpo (avião) faz giros superiores a $2 \pi$ radianos. Esta questão pode ser resolvida se ao invés de usar-se os ângulos de Euler usar-se cosenos diretores ou quaternions para definir a orientação do corpo (avião) no espaço. Entretanto, os ângulos de Euler expressam com maior simplicidade uma orientação do corpo.

\subsubsection{Trajetória da aeronave}

Para se rastrear a trajetória da aeronave com relação a $F_{E}$, deve-se conhecer as componentes de velocidade em relação a este sistema (fixo na Terra $F_{E}$ ). Então:

$\mathbf{V}_{E}=\mathbf{L}_{E B} \mathbf{V}_{B}$

onde $\mathbf{L}_{E B}$ é a matriz de cosenos diretores que fazem uma transformação $F_{B}$ para $F_{E}$ dada a seguir:

$\mathbf{L}_{E B}=\mathbf{L}_{z_{B}}(-\Psi) \mathbf{L}_{y_{B}}(-\Theta) \mathbf{L}_{x_{B}}(-\Phi)$

Após alguns cálculos, obtém-se finalmente,

$\mathbf{L}_{\mathbf{E B}}=\left[\begin{array}{ccc}\cos \theta \cos \psi & \operatorname{sen} \phi \operatorname{sen} \theta \cos \psi-\cos \phi \operatorname{sen} \psi & \cos \phi \operatorname{sen} \theta \cos \psi+\operatorname{sen} \phi \operatorname{sen} \psi \\ \cos \theta \operatorname{sen} \psi & \operatorname{sen} \phi \operatorname{sen} \theta \operatorname{sen} \psi+\cos \phi \cos \psi & \cos \phi \operatorname{sen} \theta \operatorname{sen} \psi-\operatorname{sen} \phi \cos \psi \\ -\operatorname{sen} \theta & \operatorname{sen} \phi \cos \theta & \cos \phi \cos \theta\end{array}\right]$

As equações diferenciais para obtenção das coordenadas da trajetória de vôo são dadas pela Eq. (3.28): 


$$
\left\{\begin{array}{l}
\dot{x}_{E} \\
\dot{y}_{E} \\
\dot{z}_{E}
\end{array}\right\}=\mathbf{L}_{E B} \mathbf{V}_{B}
$$

Ao integrar (3.27), são calculadas as coordenadas do CG da aeronave, para obtenção da trajetória de vôo. Assim, a matriz $L_{E B}$ multiplicada pelo vetor velocidade $(u, v, w)$ dado no sistema $F_{B}$, resulta nos valores dos termos $\dot{x}_{B}, \dot{y}_{B}, \dot{z}_{B}$, respectivamente, ou seja, nos eixos fixos no corpo da aeronave. Entretanto, para este trabalho o objetivo é encontrar os valores de $\dot{x}_{E}, \dot{y}_{E}, \dot{z}_{E}$, ou seja, com referência aos eixos fixos na terra, pois assim basta integrar os valores de $\dot{x}_{E}, \dot{y}_{E}, \dot{z}_{E}$ e obter a posição e trajetória da aeronave. Fazendo as devidas mudanças, é obtida a matriz correspondente aos valores de $\dot{x}_{E}, \dot{y}_{E}, \dot{z}_{E}$ que resulta em (ETKIN, 1996):

$$
L_{B E}=\left[\begin{array}{ccc}
\cos \theta \cdot \cos \psi & \cos \theta \cdot \operatorname{sen} \psi & -\operatorname{sen} \theta \\
\operatorname{sen} \phi \operatorname{sen} \theta \cos \psi-\cos \phi \operatorname{sen} \psi & \operatorname{sen} \phi \operatorname{sen} \theta \operatorname{sen} \psi+\cos \phi \cos \psi & \operatorname{sen} \phi \cos \theta \\
\cos \phi \operatorname{sen} \theta \cos \psi+\operatorname{sen} \phi \operatorname{sen} \psi & \cos \phi \operatorname{sen} \theta \operatorname{sen} \psi-\operatorname{sen} \phi \cos \psi & \cos \phi \cos \theta
\end{array}\right]
$$

Esta matriz multiplicada pelo vetor velocidade $(u, v, w)$ no sistema $F_{B}$, corresponde aos procurados valores de $\dot{x}_{E}, \dot{y}_{E}, \dot{z}_{E}$.

\subsubsection{Orientação da aeronave}

É necessário um conjunto de equações diferenciais que através das quais os ângulos de Euler possam ser calculados. Lembrando que:

$\boldsymbol{\omega}_{B}=\left[\begin{array}{lll}p & q & r\end{array}\right]^{T}$, tem-se que $\left[\begin{array}{c}p \\ q \\ r\end{array}\right]=\mathbf{R}\left[\begin{array}{c}\dot{\phi} \\ \dot{\theta} \\ \dot{\psi}\end{array}\right]$, onde $\mathbf{R}$ é a matriz de transformação de coordenadas apresentada a seguir: 
$\mathbf{R}=\left[\begin{array}{ccc}1 & 0 & -\operatorname{sen} \theta \\ 0 & \cos \phi & \operatorname{sen} \phi \cos \theta \\ 0 & -\operatorname{sen} \phi & \cos \phi \cos \theta\end{array}\right]$

Fazendo o inverso agora, tem-se, para a orientação da aeronave, as equações diferenciais

$\left[\begin{array}{c}\dot{\phi} \\ \dot{\theta} \\ \dot{\psi}\end{array}\right]=\mathbf{T}\left[\begin{array}{c}p \\ q \\ r\end{array}\right]$, onde $\mathbf{T}$ também é uma matriz de transformação de coordenadas que está mostrada

em (3.29):

$\mathbf{T}=\left[\begin{array}{ccc}1 & \operatorname{sen} \phi \tan \theta & \cos \phi \tan \theta \\ 0 & \cos \phi & -\operatorname{sen} \phi \\ 0 & \operatorname{sen} \phi \sec \theta & \cos \phi \sec \theta\end{array}\right]$

\subsection{Equações de movimento de Euler}

As equações gerais de corpo rígido, dadas pelas Equações (3.17) são equações de movimento onde as variáveis estão descritas no sistema inercial. No caso de aeronaves, esse conjunto de equações não é o mais conveniente para determinar seu movimento, pois no sistema inercial os momentos de inércia também são variáveis. Portanto uma forma conveniente é obter as equações do movimento no sistema de coordenadas fixo na aeronave, onde todos os momentos de inércias são funções da altitude da aeronave.

De (3.17), sabe-se que $\mathbf{f}_{E}=m \dot{\mathbf{V}}_{E}$. Aplicando a transformação de coordenadas pelos ângulos de Euler para o sistema fixo na aeronave, $F_{B}$, tem-se:

$\mathbf{L}_{E B} \mathbf{f}_{B}=m \frac{d}{d t}\left(\mathbf{L}_{E B} \mathbf{V}_{B}\right)=m\left(\dot{\mathbf{L}}_{E B} \mathbf{V}_{B}+\mathbf{L}_{E B} \dot{\mathbf{V}}_{B}\right)$

onde todos os vetores estão agora expressos em relação a $F_{B}$. 
Sabe-se que $\dot{\mathbf{L}}_{E B}=\mathbf{L}_{E B} \times \boldsymbol{\omega}_{B}=\mathbf{L}_{E B}\left[\begin{array}{ccc}0 & -r & q \\ r & 0 & -p \\ -q & p & 0\end{array}\right]$. Usando este fato, a Equação (3.30) torna-se $\mathbf{L}_{E B} \mathbf{f}_{B}=m\left(\mathbf{L}_{E B} \times \boldsymbol{\omega}_{B} \times \mathbf{V}_{B}+\mathbf{L}_{E B} \times \dot{\mathbf{V}}_{B}\right)$.

Pré-multiplicando este resultado por $\mathbf{L}_{E B}^{-1}=\mathbf{L}_{B E}$, tem-se:

$\mathbf{f}_{B}=m\left(\dot{\mathbf{V}}_{B}+\boldsymbol{\omega}_{B} \times \mathbf{V}_{B}\right)$

Usando um argumento similar à equação de momento, obtém-se:

$\mathbf{G}_{B}=\dot{\mathbf{h}}_{B}+\boldsymbol{\omega}_{B} \times \mathbf{h}_{B}$

$\mathrm{O}$ vetor de força $\mathbf{f}$ é a soma da força aerodinâmica $\mathbf{A}$ e a força gravitacional $\mathrm{mg}$, isto é, $\mathbf{f}=\mathbf{m g}+\mathbf{A}$, onde $\mathbf{A}_{B}=\left[\begin{array}{lll}X & Y & Z\end{array}\right]^{T}$ e $m \mathbf{g}_{B}=m \mathbf{L}_{B E} \mathbf{g}_{E}=m \mathbf{L}_{E B}\left[\begin{array}{lll}0 & 0 & g\end{array}\right]^{\mathrm{T}}$. É importante lembrar que, como se trata de um corpo rígido, $\dot{\mathbf{I}}_{B}=0$.

Usando (3.19) e denotando $\mathbf{V}_{B}=\left[\begin{array}{lll}u & v & w\end{array}\right]$ e $\mathbf{G}_{\mathbf{B}}=\left[\begin{array}{lll}L & M & N\end{array}\right]^{T}$, as Equações. (3.31) e (3.32) são expandidas obtendo-se:

$$
\begin{aligned}
& X-m g \operatorname{sen} \theta=m(\dot{u}+q w-r v) \\
& Y+m g \cos \theta \operatorname{sen} \phi=m(\dot{v}+r u-p w) \\
& Z+m g \cos \theta \cos \phi=m(\dot{w}+p v-q u) \\
& L=I_{x} \dot{p}-I_{y z}\left(q^{2}-r^{2}\right)-I_{z x}(\dot{r}+p q)-I_{x y}(\dot{q}-r p)-\left(I_{y}-I_{z}\right) q r \\
& M=I_{y} \dot{q}-I_{z x}\left(r^{2}-p^{2}\right)-I_{x y}(\dot{p}+q r)-I_{y z}(\dot{r}-p q)-\left(I_{z}-I_{x}\right) r p \\
& N=I_{z} \dot{r}-I_{x y}\left(p^{2}-q^{2}\right)-I_{y z}(\dot{q}+r p)-I_{z x}(\dot{p}-q r)-\left(I_{x}-I_{y}\right) p q
\end{aligned}
$$




\subsubsection{Escolha dos Eixos da Aeronave}

Para aeronaves convencionais, devido à simetria, pode-se assumir que: $I_{x y}=I_{y x}=I_{y z}=I_{z y}=0$.

As direções $x$ e $z$ no plano de simetria podem ser fixadas de acordo com a Figura 3.4.

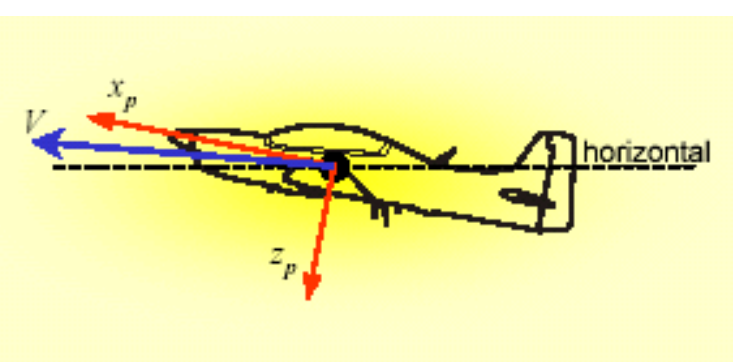

(a)

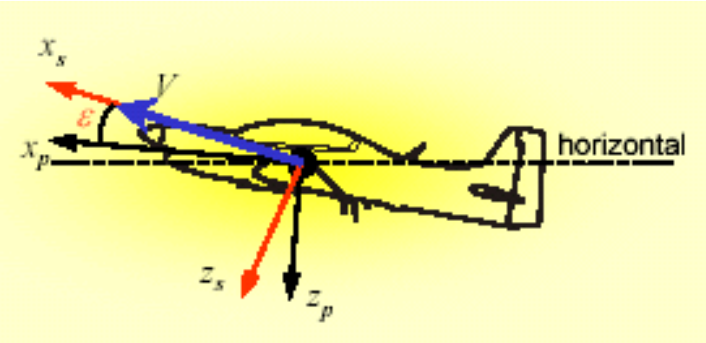

(b)

Figura 3.4. Ilustração dos eixos da aeronave:(a) Eixos principais e (b) Eixos de estabilidade $\varepsilon>0$ (MARQUES, 2004)

\subsubsection{Eixos principais}

Quando o sistema de eixos é o sistema de eixos principais de inércia vale $I_{x z}=I_{z x}=0$ e o resultado é

$h_{x}=I_{x} p$

$h_{y}=I_{y} q$

$h_{z}=I_{z} r$.

\subsubsection{Eixos de estabilidade}

Quando se tem a direção $x$ alinhada com a velocidade do vento relativo em vôo estacionário equilibrado, têm-se os eixos chamados de eixos de estabilidade. Neste caso então, $v=$ $w=0$. O sistema neste caso varia com a condição de estabilidade ou seja, a direção inicial do fluxo do ar sobre a aeronave. As seguintes fórmulas são convenientes para calcular $I_{x}, I_{z}$ e $I_{z x}$ quando forem conhecidos $I_{x_{P}}$ e $I_{z_{P}}$ para os eixos principais. 
$I_{x}=I_{x_{P}} \cos ^{2} \varepsilon+I_{z_{P}} \operatorname{sen}^{2} \varepsilon$

$I_{z}=I_{x_{P}} \operatorname{sen}^{2} \varepsilon+I_{z_{P}} \cos ^{2} \varepsilon$

$I_{z x}=\frac{1}{2}\left(I_{z_{P}}-I_{x_{P}}\right) \operatorname{sen} 2 \varepsilon$

onde $\varepsilon$ é o ângulo entre $x_{p}$ (eixo principal de inércia) e $x_{s}$ (eixo de estabilidade) positivo como mostrado na Figura 3.4.

Uma grande vantagem no uso destes eixos é a obtenção de simplificações no cálculo dos esforços aerodinâmicos.

Neste trabalho também serão desprezados os efeitos dos rotores girantes.

\subsubsection{Conjunto Completo das Equações de Movimento}

Admitindo-se que o plano $x z$ é de simetria e $I_{x y}=I_{y z}=0$, chega-se ao conjunto de equações de movimento, que pode-se dividir em:

\section{a) Equações dinâmicas}

A seguir será apresentado em (3.36) e (3.37) o conjunto completo de equações dinâmicas da aeronave, já tendo sido desprezados os efeitos dos rotores girantes.

$X-m g \operatorname{sen} \theta=m(\dot{u}+q w-r v)$

$Y+m g \cos \theta \operatorname{sen} \phi=m(\dot{v}+r u-p w)$

$Z+m g \cos \theta \cos \phi=m(\dot{w}+p v-q u)$

$L=I_{x} \dot{p}-I_{y z}\left(q^{2}-r^{2}\right)-I_{z x}(\dot{r}+p q)-I_{x y}(\dot{q}-r p)-\left(I_{y}-I_{z}\right) q r$

$M=I_{y} \dot{q}-I_{z x}\left(r^{2}-p^{2}\right)-I_{x y}(\dot{p}+q r)-I_{y z}(\dot{r}-p q)-\left(I_{z}-I_{x}\right) r p$

$N=I_{z} \dot{r}-I_{x y}\left(p^{2}-q^{2}\right)-I_{y z}(\dot{q}+r p)-I_{z x}(\dot{p}-q r)-\left(I_{x}-I_{y}\right) p q$

\section{b) Equações cinemáticas}

As equações de movimento cinemáticas são dadas por: 
$p=\dot{\phi}-\dot{\psi} \operatorname{sen} \theta$

$q=\dot{\theta} \cos \phi+\dot{\psi} \cos \theta \operatorname{sen} \phi$

$r=\dot{\psi} \cos \theta \cos \phi-\dot{\theta} \operatorname{sen} \phi$

que resolvendo em termos de $\phi, \theta$ e $\psi$, torna - se :

$\dot{\phi}=p+q \operatorname{sen} \phi \tan \theta+r \cos \phi \tan \theta$

$\dot{\theta}=q \cos \phi-r \operatorname{sen} \phi$

$\dot{\psi}=(q \sin \phi+r \cos \phi) / \cos \theta$

e neste trabalho trabalha-se com (3.38) (b).

$\dot{x}_{E}=u^{E} \cos \theta \cos \psi+v^{E}(\operatorname{sen} \phi \operatorname{sen} \theta \cos \psi-\cos \phi \operatorname{sen} \psi)+\left(w^{E}(\cos \phi \operatorname{sen} \theta \cos \psi+\operatorname{sen} \phi \operatorname{sen} \psi)\right)$

$\dot{y}_{E}=u^{E} \cos \theta \operatorname{sen} \psi+v^{E}(\operatorname{sen} \phi \operatorname{sen} \theta \operatorname{sen} \psi+\cos \phi \cos \psi)+\left(w^{E}(\cos \phi \operatorname{sen} \theta \operatorname{sen} \psi-\operatorname{sen} \phi \cos \psi)\right)(3.39)$

$\dot{z}_{E}=-u^{E} \operatorname{sen} \theta+v^{E} \operatorname{sen} \phi \cos \theta+w^{E} \cos \phi \cos \theta$

onde $\left\{\begin{array}{l}u^{E}=u+W_{x} \\ v^{E}=v+W_{y} \\ w^{E}=w+W_{z}\end{array}\right.$

Mas como $W_{x}=W_{y}=W_{z}=0$, pois são componentes da velocidade do vento que foi desprezada, $u^{E}=u, v^{E}=v$ e $w^{E}=w$, fazendo com que (3.39) torne-se:

$\dot{x}_{E}=u \cos \theta \cos \psi+v(\operatorname{sen} \phi \operatorname{sen} \theta \cos \psi-\cos \phi \operatorname{sen} \psi)+(w(\cos \phi \operatorname{sen} \theta \cos \psi+\operatorname{sen} \phi \operatorname{sen} \psi))$

$\dot{y}_{E}=u \cos \theta \operatorname{sen} \psi+v(\operatorname{sen} \phi \operatorname{sen} \theta \operatorname{sen} \psi+\cos \phi \cos \psi)+(w(\cos \phi \operatorname{sen} \theta \operatorname{sen} \psi-\operatorname{sen} \phi \cos \psi))$

$\dot{z}_{E}=-u \operatorname{sen} \theta+v \operatorname{sen} \phi \cos \theta+w \cos \phi \cos \theta$

Das equações diferenciais de movimento, pode-se observar que 3 das (3.38) não são independentes, e então apenas 12 são equações independentes. Destaca-se também que neste trabalho será usada a (3.38) (b).

\subsubsection{Discussão sobre as Equações de Movimento}

As equações acima apresentam algumas hipóteses simplificadoras. A aeronave foi considerada como sendo um corpo rígido com seis graus de liberdade, com um plano longitudinal de simetria, e sob o efeito das forças aerodinâmicas e da gravidade. A atmosfera é considerada em repouso, e são desprezados os efeitos de rotação da Terra e as forças de propulsão. 
Pode-se dividir então as equações de movimento como mostra o esquema da Figura 3.5:

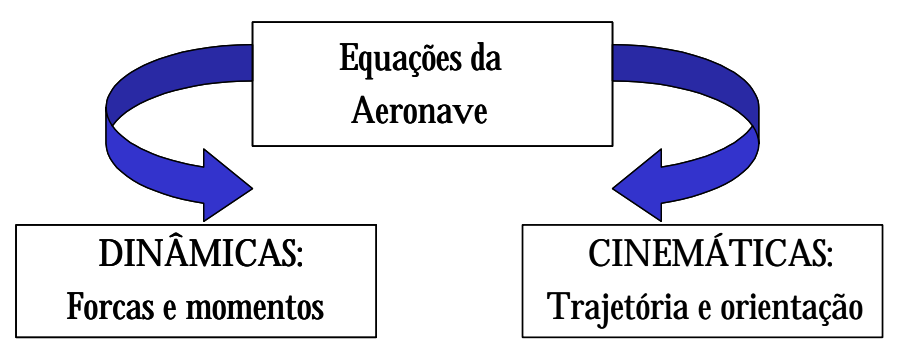

Figura 3.5. Ilustração do esquema das Equações da aeronave.

Como mostrado anteriormente, o conjunto das equações de movimento de uma aeronave rígida é formado por 12 equações diferenciais ordinárias não lineares na variável independente $t$, onde $X, Y, Z$ são as forças aerodinâmicas e $L, M e N$ os momentos aerodinâmicos. Pode-se observar também que as três forças e três momentos são funções das velocidades lineares e angulares $(u, v, w, p, q, r)$ da aeronave e de um vetor de controle. Este vetor pode ser escrito como $\mathbf{c}=\left[\delta_{a}, \delta_{e}, \delta_{r}\right]^{T}$, sendo as componentes do vetor, respectivamente os ângulos de deflexão de aileron, profundor e leme da aeronave.

Já, as variáveis dependentes do sistema são:

posição do CG da aeronave em relação ao sistema inercial: $x_{E}, y_{E}, z_{E}$;

Atitude: $\psi, \theta, \phi$;

Velocidade linear: $u, v, w$;

Velocidade angular: $p, q, r$.

\subsubsection{Conjunto de Equações implementado}

A seguir será apresentado o conjunto de equações não lineares que definem o movimento de uma aeronave que foi usado na simulação do modelo. Nesta fase, as variáveis que serão calculadas já foram isoladas e os efeitos dos rotores girantes já foram desprezados, como mostrado a seguir.

$$
\begin{aligned}
& \dot{u}=\frac{X}{m}-g \cdot \operatorname{sen} \theta-q \cdot w+r \cdot v \\
& \dot{v}=\frac{Y}{m}+g \cdot \cos \theta \cdot \operatorname{sen} \phi-r \cdot u+p \cdot w
\end{aligned}
$$


$\dot{w}=\frac{Z}{m}+g \cdot \cos \theta \cdot \cos \phi-p \cdot v+q \cdot u$

$\dot{p}=\frac{L+I_{z x}(\dot{r}+p \cdot q)+\left(I_{y}-I_{z}\right) q \cdot r}{I_{x}}$

$\dot{q}=\frac{M+I_{z x}\left(r^{2}-p^{2}\right)+\left(I_{z}-I_{x}\right) r \cdot p}{I_{y}}$

$\dot{r}=\frac{N+I_{z x}(\dot{p}-q r)+\left(I_{x}-I_{y}\right) p \cdot q}{I_{z}}$

$\dot{\phi}=p+(q \cdot \sin \phi+r \cdot \cos \phi) \cdot \tan \theta$

$\dot{\theta}=q \cdot \cos \phi-r \cdot \sin \phi$

$\dot{\psi}=(q \cdot \sin \phi+r \cdot \cos \phi) \cdot \sec \theta$

$\dot{x}=u \cdot \cos \theta \cdot \cos \psi+v \cdot(\operatorname{sen} \phi \cdot \operatorname{sen} \theta \cdot \cos \psi-\cos \phi \cdot \operatorname{sen} \psi)$

$+w \cdot(\cos \phi \cdot \operatorname{sen} \theta \cdot \cos \psi+\operatorname{sen} \phi \cdot \operatorname{sen} \psi)$

$\dot{y}=u \cdot \cos \theta \cdot \sin \psi+v \cdot(\sin \phi \cdot \sin \theta \cdot \sin \psi+\cos \phi \cdot \cos \psi)$

$+w(\cos \phi \sin \theta \sin \psi-\sin \theta \cos \psi)$

$\dot{z}=-u \cdot \sin \theta+v \cdot \sin \phi \cdot \cos \theta+w \cdot \cos \phi \cdot \cos \theta$

Como dito anteriormente, $u, v$ e $w$ representam as velocidades lineares horizontal, lateral e vertical da aeronave, respectivamente; $p, q$ e $r$ representam as velocidades angulares de rolagem, arfagem e guinada respectivamente; $X, Y$ e $Z$ representam as forças aerodinâmicas nas direções longitudinal, lateral e vertical da aeronave, respectivamente; $L, M$ e $N$ representam os momentos aerodinâmicos de rolagem, arfagem e guinada respectivamente; $\phi, \theta$ e $\psi$ representam os ângulos de rolagem, arfagem e guinada respectivamente (ângulos de Euller); $x, y$ e $z$ representam a posição. Ainda, $m$ representa a massa total da aeronave, $I_{x}, I_{y}$ e $I_{z}$ representam os momentos de 
inércia em torno de $O x, O y$ e $O z$, respectivamente, $I_{x y}, I_{y z}$ e $I_{z x}$ representam os produtos de inércia com relação aos planos $O x y, O y z$ e $O z x$.

O conjunto de equações cinemáticas e do movimento apresentadas anteriormente consiste de equações diferenciais ordinárias não lineares acopladas na variável independente $t$. As forças e momentos aerodinâmicos são considerados de forma implícita e sabe-se que esses termos dependem do movimento relativo da aeronave em vôo e que podem introduzir termos não lineares complexos. Portanto, a aplicação de linearização é bastante desejada para trabalhar com estas equações. Em (MARQUES, 2003) pode ser encontrada por completo a descrição da Teoria das Pequenas Perturbações e neste trabalho serão descritas brevemente sua filosofia e sua aplicação apenas às forças e momentos aerodinâmicos da aeronave.

\subsubsection{Breve descrição da Teoria de pequenas perturbações}

Segundo MARQUES (2003) para a aplicação desse método para a linearização é necessário primeiramente adotar uma condição de vôo de referência, a partir da qual as respostas dinâmicas da aeronave são contabilizadas por meio de variáveis de perturbação. Seja, por exemplo, a força $X$ que para uma condição de referência $X_{0}$, pode ser substituída na equação por $X=X_{0}+\Delta X$. Fazendo o mesmo para as demais forças e momentos, tais equações tornam-se equações representadas pelas novas variáveis de perturbação $\Delta X, \Delta Y, \Delta Z, \Delta L, \Delta M$ e $\Delta N$ também chamadas de variáveis perturbadas. Destaca-se que será omitido o $\Delta$ para simplificar a notação usada.

\subsubsection{Carregamento Aerodinâmico Linear}

Forças e momentos aerodinâmicos são estritamente funcionais das variáveis que os representam, ou seja, o carregamento aerodinâmico depende da história no tempo completa dessas variáveis. A relação funcional entre um termo de carga aerodinâmica não estacionária, $F(t)$, e uma variável que a representa, $\xi(t)$, pode ser expressa por $F(t)=F[\xi(\tau), t]$, com $-\infty \leq \tau \leq t$. Como o funcional $F(t)$ é dificilmente obtido explicitamente, para aplicação em dinâmica de vôo é possível manipulá-lo para torná-lo linear e então apropriado para determinar funções aerodinâmicas dependentes das variáveis de perturbações utilizadas. Tomando $\xi(\tau)$ do funcional dado anteriormente e o expressando em termos de uma expansão em série de Taylor em torno 
da $\quad$ variável $t$ tem-se $\quad \xi(\tau)=\xi(\tau)+(\tau-t) \dot{\xi}(\tau)+\frac{1}{2}(\tau-t)^{2} \ddot{\xi}(\tau)+\ldots, \quad$ ficando $F(t)=F[\xi(t), \dot{\xi}(t), \ddot{\xi}(t), \ldots]$

Aplicando-se novamente série de Taylor nas variáveis $\xi, \dot{\xi}, \ddot{\xi}, \ldots$, para $\mathrm{t}=0$, tem-se $F(t) \approx \frac{\partial F}{\partial \xi} \xi+\frac{\partial^{2} F}{\partial \xi^{2}} \frac{\xi^{2}}{2}+\ldots+\frac{\partial F}{\partial \dot{\xi}} \dot{\xi}+\ldots$, que truncando-se de modo a manter apenas os termos lineares, tem-se $F(t)$ como função das variáveis $\xi, \dot{\xi}, \ddot{\xi}, \ldots$. Estes termos da derivada podem ser denominados de derivada de estabilidade ou aerodinâmica. Deste modo, $F(t)$ pode ser descrito como $F(t) \approx \frac{\partial F}{\partial \xi} \xi+\frac{\partial F}{\partial \dot{\xi}} \dot{\xi}+\frac{\partial F}{\partial \ddot{\xi}} \ddot{\xi}+\ldots=F_{\xi} \xi+F_{\dot{\xi}} \dot{\xi}+F_{\ddot{\xi}} \ddot{\xi}+\ldots$

Este resultado entrado para $F(t)$, é uma forma de representar o carregamento aerodinâmico nas variáveis relevantes do vôo. Portanto as perturbações $(X, Y, Z)$ e $(L, M, M)$ necessárias para as equações de movimento podem ser expressas como funções das variáveis do problema e são representadas pelas seguintes equações:

$$
\begin{aligned}
& X=X_{u} \cdot u+X_{w} \cdot w+X_{\dot{w}} \cdot \dot{w}+X_{q} \cdot q+X_{\delta_{e}} \cdot \Delta \delta_{e} \\
& Y=Y_{v} \cdot v+Y_{p} \cdot p+Y_{r} \cdot r+Y_{\delta_{a}} \cdot \Delta \delta_{a}+Y_{\delta_{r}} \cdot \Delta \delta_{r} \\
& Z=Z_{u} \cdot u+Z_{w} \cdot w+Z_{\dot{w}} \cdot \dot{w}+Z_{q} \cdot q+Z_{\delta_{e}} \cdot \Delta \delta_{e} \\
& L=L_{v} \cdot v+L_{p} \cdot p+L_{r} \cdot r+L_{\delta_{a}} \cdot \Delta \delta_{a}+L_{\delta_{r}} \cdot \Delta \delta_{r} \\
& M=M_{u} \cdot u+M_{w} \cdot w+M_{\dot{w}} \cdot \dot{w}+M_{q} \cdot q+M_{\delta_{e}} \cdot \Delta \delta_{e} \\
& N=N_{v} \cdot v+N_{p} \cdot p+N_{r} \cdot r+N_{\delta_{a}} \cdot \Delta \delta_{a}+N_{\delta_{r}} \cdot \Delta \delta_{r}
\end{aligned}
$$

onde $X_{u}, X_{w}, X_{\dot{w}}, X_{q}, X_{\delta_{e}}, Y_{v}, Y_{p}, Y_{r}, Y_{\delta_{a}}, Y_{\delta_{r}}, Z_{u}, Z_{w}, Z_{\dot{w}}, Z_{q}, Z_{\delta_{e}}, L_{v}, L_{p}, L_{r}, L_{\delta_{a}}$, $L_{\delta_{r}}, M_{u}, M_{w}, M_{\dot{w}}, M_{q}, M_{\delta_{e}} N_{v}, N_{p}, N_{r}, N_{\delta_{a}}$ e $N_{\delta_{r}}$ representam as derivadas aerodinâmicas de estabilidade e estão descritas no Apêndice 1 e $\Delta \delta_{e}, \Delta \delta_{a}$ e $\Delta \delta_{r}$ são as variações nos controles.

Nos dados retirados de SCHIMIDT (1998), algumas derivadas são apresentadas com relação a $\alpha$ e não com relação a $w$ e as derivadas em relação a $v$ estavam dadas com relação a $\beta$. Como no equacionamento realizado foram usadas as derivadas em relação a $w$ e $v$, foi 
necessário realizar algumas transformações. As Figura 3.6 (a) e 3.6 (b) mostram dois gráficos onde pode-se observar as relações entre estas variáveis:

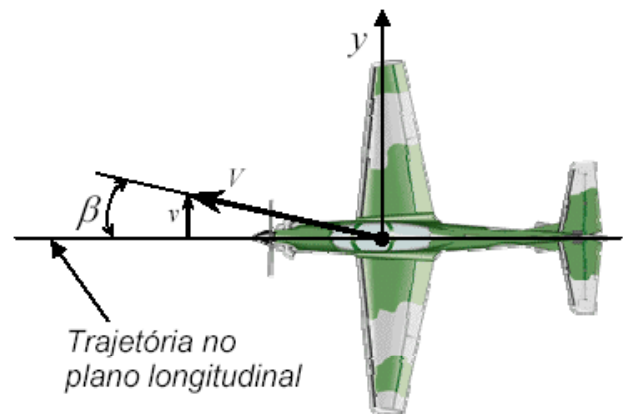

(a)

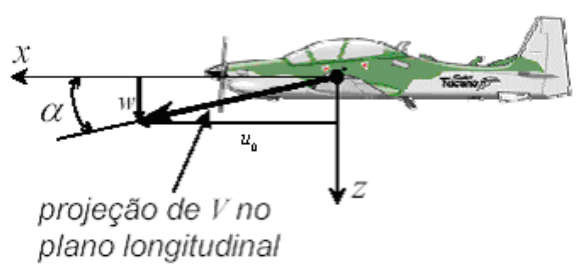

(b)

Figura 3.6. (a) Esquema mostrando relação entre $\beta$ e $v$. (b) Esquema mostrando relação entre $\alpha$ e $w$ (MARQUES, 2004).

Resumidamente, pode-se fazer como indicado na Figura 3.7:

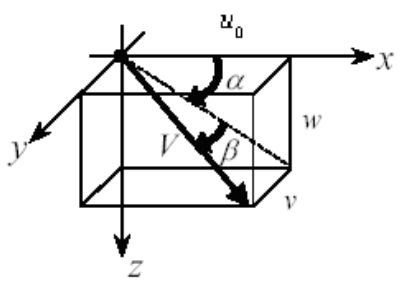

Figura 3.7. Ilustração do esquema mostrando relação entre $\beta$ e $v$ e $\alpha$ e $w$ (MARQUES, 2004).

Pode-se adotar então: $\alpha=\frac{w}{u_{0}}$ e $\beta=\frac{v}{u_{0}}$ e conseqüentemente fazer:

$$
\begin{aligned}
& w=\alpha \cdot u_{0} \rightarrow X_{w}=\frac{\partial X}{\partial w}=\frac{\partial X}{\partial\left(\alpha \cdot u_{0}\right)} \rightarrow u_{0}=\text { cte } \rightarrow \frac{\partial X}{\partial(\alpha)} \cdot \frac{1}{u_{0}}=\frac{X_{\alpha}}{u_{0}} \rightarrow u_{0}=\mathrm{V} \rightarrow X_{w}=\frac{X_{\alpha}}{V} \\
& v=\beta \cdot u_{0} \rightarrow X_{v}=\frac{\partial X}{\partial v}=\frac{\partial X}{\partial\left(\beta \cdot u_{0}\right)} \rightarrow u_{0}=\text { cte } \rightarrow \frac{\partial X}{\partial(\beta)} \cdot \frac{1}{u_{0}}=\frac{X_{\beta}}{u_{0}} \rightarrow u_{0}=\mathrm{V} \rightarrow X_{v}=\frac{X_{\beta}}{V}
\end{aligned}
$$

E ainda, para trabalhar com estas derivadas de estabilidade, deverá ser feita a compatibilização com as definidas em ETKIN \& REID (1996), já que o modelo matemático usado foi baseado no equacionamento apresentado por eles. Ou seja, as derivadas $X_{i}, Y_{i}$ e $Z_{i}$ deverão ser divididas pela massa da aeronave, as derivadas $M_{i}$ por $I_{y}, L_{i}$ por $I_{x}$ e $N_{i}$ por $I_{z}$, onde os subscritos $i$ representam as variáveis $(u, v, w),(p, q, r)$ e $(\phi, \psi, \theta)$. 
Como o equacionamento usado foi o definido por ETKIN \& REID (1996), somente após terem sido feitas as compatibilizações de unidades que as derivadas foram utilizadas na simulação. As modificações feitas com as derivadas de movimento longitudinal e com relação às derivadas de movimento lateral são apresentadas no Apêndice 1 deste trabalho.

Finalmente, fazendo todas estas substituições, é obtido o conjunto completo de equações de movimento implementadas para obter o simulador. Este modelo matemático apresentado foi implementado no Simulink, possibilitando então a simulação da dinâmica de vôo de aeronaves. Os dados geométricos, dados aerodinâmicos, derivadas de estabilidade dimensionais e coeficientes aerodinâmicos são passados como parâmetros de entrada para o software. Estes dados são carregados automaticamente do ambiente Matlab ${ }^{\circledR}$, após serem rodadas as rotinas que os contêm. O programa retorna como saída valores numéricos de: velocidade linear, velocidade angular e orientação da aeronave. O programa resolve o sistema de equações apresentado através do método interativo de integração numérica Runge-Kutta de $4^{\mathrm{a}}$ ordem, conforme descrito na literatura. A análise do comportamento da aeronave é feita comparando os resultados de simulações realizadas para diferentes condições de vôo, variando as entradas nos controles da aeronave.

Desprezando algumas derivadas por terem valores extremamente pequenos, fazendo todas as substituições de forças e momentos aerodinâmicos fazendo algumas simplificações algébricas, obtém-se finalmente o conjunto de Equações de (3.58) a (3.63) a ser implementado no Simulink ${ }^{\circledR}$ :

$$
\begin{aligned}
& \dot{u}=\frac{X_{u}}{m} u+\frac{X_{w}}{m} w-g \cdot \operatorname{sen} \theta-q \cdot w+r \cdot v+X_{\delta_{e}} \delta_{e} \\
& \dot{v}=\frac{Y_{v}}{m} v+\frac{Y_{p}}{m} p+\frac{Y_{r}}{m} r+g \cdot \cos \theta \cdot \operatorname{sen} \phi-r\left(u+U_{0}\right)+p \cdot w+Y_{\delta_{r}} \delta_{r} \\
& \dot{w}=\frac{Z_{u}}{k} u+\frac{Z_{w}}{k} w+\frac{Z_{q}}{k} q+\frac{m U_{0}}{k} q+\frac{m g}{k} \cdot \cos \theta \cdot \cos \phi-p \cdot v+q \cdot\left(u+U_{0}\right) \frac{m}{k}+\frac{Z_{\delta_{e}} \delta_{e}}{k}
\end{aligned}
$$

$$
\begin{aligned}
& \dot{p}=L_{v} v+L_{p} p+L_{r} r+\frac{I_{z x}}{I_{z}}\left(N_{v} v+N_{p} p+N_{r} r+\left(I_{x}-I_{y}+I_{z}\right) p q\right)+I_{y}-I_{z}-\left(\frac{\left(\frac{I_{z x}^{2}}{I_{z}}\right) q r}{\left(I_{x}-\frac{I_{z x}^{2}}{I_{z}}\right)+}\right. \\
& N_{\delta_{r}} \delta_{r} \cdot k_{2}+L_{\delta_{r}} \delta_{r} k_{1}+N_{\delta_{a}} \delta_{a} k_{2}+L_{\delta_{a}} \delta_{a} k_{1}
\end{aligned}
$$




$$
\begin{aligned}
& \dot{q}=\left(M_{u} u+M_{w} w+M_{\dot{w}} \frac{Z_{u}}{k} u+\left(M_{\dot{w}} \frac{Z_{w}}{k}\right) w+\left(M_{\dot{w}} \frac{Z_{q}+m U_{0}}{k}\right) q+g \frac{k}{m} \cos \theta \cos \phi-\frac{m}{k} q v+\right. \\
& \left.\frac{k}{m} q\left(u+U_{0}\right)+M_{q} q+I_{z x}\left(r^{2}-p^{2}\right)+\left(I_{z}-I_{x}\right) r p\right) I_{y}+Z_{\delta_{e}} \delta_{e} \cdot k_{3}+\frac{M_{\delta_{e}}}{I_{y}} \delta_{e}
\end{aligned}
$$

$$
\dot{r}=N_{v} v+N_{p} p+N_{r} r+\frac{I_{z x}}{I_{x}}\left(L_{v} v+L_{p} p+L_{r} r+\left(I_{y}-I_{z}-I_{x}\right) q r\right)+\frac{\left(I_{x}-I_{z}+\frac{I_{z x}{ }^{2}}{I_{x}} p q\right)}{\left(I_{z}-\frac{I_{z x}{ }^{2}}{I_{x}}\right)}+
$$

$N_{\delta_{r}} \delta_{r} \cdot k_{4}+L_{\delta_{r}} \delta_{r} k_{5}+N_{\delta_{a}} \delta_{a} k_{4}+L_{\delta_{a}} \delta_{a} k_{5}$

onde:

$k=m-Z_{\dot{w}}$

$$
k_{1}=\frac{1}{I_{x}-\frac{I_{z x}{ }^{2}}{I_{z}}}, k_{2}=\frac{\frac{I_{z x}}{I_{z}}}{I_{x}-\frac{I_{z x}{ }^{2}}{I_{z}}}, k_{3}=\frac{M_{\dot{w}}}{I_{y}}, k_{4}=\frac{1}{I_{z}-\frac{I_{z x}{ }^{2}}{I_{x}}} \mathrm{e} k_{5}=\frac{\frac{I_{z x}}{I_{x}}}{I_{x}-\frac{I_{z x}{ }^{2}}{I_{z}}}
$$

As equações apresentadas anteriormente (3.46), (3.47), (3.48), (3.49), (3.50) e (3.51) não se alteram.

\subsection{Conclusões}

Neste capítulo foi apresentado o equacionamento completo do modelo matemático não linear do movimento de uma aeronave e sua implementação usando o pacote Simulink. A representação deste sistema foi feita através de um conjunto de 12 equações diferenciais ordinárias, tratando-se a aeronave como corpo rígido com 6 graus de liberdade, com um plano longitudinal de simetria e sob o efeito das forças aerodinâmicas e da gravidade. Para simplificar o equacionamento, também foram desprezados os efeitos de rotação da Terra e os efeitos de forças de propulsão e a atmosfera foi considerada em repouso. 


\section{CAPÍTULO 4}

\section{RESULTADOS DA SIMULAÇÃO E DA IDENTIFICAÇÃO DAS RESPOSTAS DE UMA AERONAVE MILITAR DE ATAQUE DENTRO DE UM ENVELOPE DE Vôo}

\subsection{Introdução}

Neste capítulo será primeiramente discutido o desenvolvimento matemático do modelo dinâmico não linear da aeronave onde as forças e momentos aerodinâmicos foram equacionados para pequenas perturbações (aerodinâmica linearizada). Em seguida serão também apresentados a simulação e os resultados da identificação do envelope de vôo utilizando redes neurais recorrentes. Serão usados os dados de uma aeronave militar de ataque A4-D, especialmente desenvolvida para operar de porta-aviões, conforme McRUER et al. (1973) e SCHIMIDT (1998).

\subsection{Dados para simulação da aeronave usada para estudo de caso}

Os dados da aeronave usada para simulação foram obtidos de McRUER et al. (1973) e de SCHIMIDT (1998) e são da aeronave A4-D como dito anteriormente. Estes e outros dados importantes para simulação são:

$\theta=0$ [graus] - atitude de arfagem;

$g=9,81\left[\mathrm{~m} / \mathrm{s}^{2}\right]-$ aceleração da gravidade;

$W=78.186,9$ [newton] - peso da aeronave;

$m=8512,1[\mathrm{~kg}]-$ massa da aeronave;

$S=24,1548\left[\mathrm{~m}^{2}\right]-$ área da asa; 
$b=8,3820[\mathrm{~m}]$ - envergadura das asas da aeronave;

$c=3,2918[\mathrm{~m}]-$ corda média das asas da aeronave.

Serão analisados 9 casos, cujos parâmetros de vôo são mostrados na Tabela 4.1. Os dados correspondentes aos casos 1, 2, 3, 4, 8 e 9 foram retirados de SCHIMIDT (1998) e os dados correspondentes aos casos 5, 6 e 7 de McRUER et al. (1973), sendo todos devidamente convertidos para as unidades no Sistema Internacional.

\begin{tabular}{|c|l|l|l|l|l|l|l|l|l||}
\hline DADOS & CASO 1 & CASO 2 & CASO 3 & CASO 4 & CASO 5 & CASO 6 & CASO 7 & CASO 8 & CASO 9 \\
\hline$h[$ metros $]$ & 0 & 4572 & 4572 & 10668 & 0 & 10668 & 4572 & 4572 & 10668 \\
\hline Mach & 0,4 & 0,4 & 0,6 & 0,6 & 0,2 & 0,5 & 0,4 & 0,9 & 0,9 \\
\hline$V[\mathrm{~m} / \mathrm{s}]$ & 136 & 129 & 193 & 178 & 68 & 148 & 129 & 290 & 267 \\
\hline$Q\left[\mathrm{~N} / \mathrm{m}^{2}\right]$ & 11347 & 6416 & 14411 & 6033 & 2834,4 & 4165,4 & 6415,6 & 32413 & 13549 \\
\hline$I x\left[\mathrm{~kg} / \mathrm{m}^{2}\right]$ & 10871 & 11115 & 10857 & 11101 & 22297 & 11643 & 11101 & 10925 & 10857 \\
\hline$I y\left[\mathrm{~kg} / \mathrm{m}^{2}\right]$ & 35106 & 35106 & 35106 & 35106 & 39715 & 35106 & 35106 & 35106 & 35106 \\
\hline$I z\left[\mathrm{~kg} / \mathrm{m}^{2}\right]$ & 39674 & 39430 & 39688 & 39444 & 47739 & 38942 & 39498 & 39620 & 39688 \\
\hline$I x z\left[\mathrm{~kg} / \mathrm{m}^{2}\right]$ & $-597,8$ & -2696 & 55,6 & $-2.645,8$ & $-7929,4$ & $-4689,9$ & $-2702,8$ & 1409,7 & 307,6884 \\
\hline$\alpha$ trim $[\mathrm{graus}]$ & 4,7 & 8,9 & 3,4 & 8,8 & 19,5 & 13 & 8,9 & 0,7 & 2,9 \\
\hline$\rho\left[\mathrm{kg} / \mathrm{m}^{3}\right]$ & 1,225 & 0,77082 & 0,77082 & 0,37960 & 1,22500 & 0,37960 & 0,77082 & 0,77082 & 0,37960 \\
\hline
\end{tabular}

Tabela 4.1 - Altitudes, velocidades, número de Mach e dados geométricos usados para simulação (McRUER et al., 1973; SCHIMIDT, 1998).

Como se pode observar na Tabela 4.1, há duas condições de vôo em regime transônico $(M=0,9)$ e duas condições com altitudes iguais a zero que significam que o avião está voando rasante levemente acima do nível do mar.

Nas Tabelas 4.2 e 4.3 são apresentadas as derivadas de estabilidade da aeronave para os respectivos casos de interesse (ver Tabela 4.1), sendo que, na Tabela 4.2 estão as derivadas láterodirecional dimensionais e na Tabela 4.3 as derivadas longitudinais dimensionais da aeronave usada para mostrar o estudo de caso. O modelo matemático implementado usa as derivadas na forma dimensional e para isto é necessário que algumas conversões de unidades sejam realizadas. O apêndice apresenta as fórmulas matemáticas aplicadas para a realização destas conversões. 


\begin{tabular}{|c|c|c|c|c|c|c|c|c|c|}
\hline DERIVADAS & CASO 1 & CÃSO 2 & CASO 3 & CASO 4 & CÃSO 5 & CASO 6 & CASO 7 & CASO 8 & CASO 9 \\
\hline$Y_{\beta}\left[\mathrm{m} / \mathrm{s}^{2}\right]$ & $-33,814$ & $-19,0256$ & $-44,0741$ & $-18,4038$ & $\begin{array}{l}-6,9799 \\
\end{array}$ & $-12,8016$ & $-19,0256$ & $-105,217$ & $-42,61104$ \\
\hline$Y_{p}$ & 0 & 0 & 0 & 0 & 0 & 0 & 0 & 0 & 0 \\
\hline$Y_{r}$ & 0 & 0 & 0 & 0 & $-0,1026$ & $-0,0864$ & 0 & 0 & 0 \\
\hline$L_{\beta}\left[\mathrm{s}^{-2}\right]$ & $-27,67$ & $-14,01$ & $-35,00$ & $-14,24$ & $-3,21$ & $-6,4$ & $-14,02$ & $-87,19$ & $-40,32$ \\
\hline$L_{p}\left[\mathrm{~s}^{-1}\right]$ & $-1,732$ & $-0,988$ & $-1,516$ & $-0,671$ & $-0,412$ & $-0,534$ & $-0,987$ & $-2,492$ & $-1,134$ \\
\hline$L_{r}\left[\mathrm{~s}^{-1}\right]$ & 0,933 & 0,607 & 0,874 & 0,464 & 0,608 & 0,288 & 0,608 & 1,346 & 0,672 \\
\hline$N_{\beta}\left[\mathrm{s}^{-2}\right]$ & 15,16 & 8,223 & 18,78 & 7,864 & 2,8 & 5,44 & 8,21 & 46,43 & 19,65 \\
\hline$N_{p}\left[\mathrm{~s}^{-1}\right]$ & 0,040 & 0,000 & 0,040 & $-0,004$ & $-0,111$ & 0 & 0 & 0,125 & 0,041 \\
\hline$N_{r}\left[\mathrm{~s}^{-1}\right]$ & $-0,639$ & $-0,401$ & $-0,566$ & $-0,291$ & $-0,296$ & $-0,24$ & $-0,4$ & $-0,958$ & $-0,428$ \\
\hline$Y_{\delta_{r}}\left[\mathrm{~m} / \mathrm{s}^{2}\right]$ & 5,9893 & 3,3010 & 7,6474 & 3,1882 & 1,1278 & 2,2189 & 2,7188 & 15,92275 & 6,638544 \\
\hline$L_{\delta_{r}}\left[\mathrm{~s}^{-2}\right]$ & 7,305 & 2,802 & 9,961 & 2,739 & 0,1284 & 1,164 & 2,802 & 24,05 & 8,568 \\
\hline$N_{\delta_{r}}\left[\mathrm{~s}^{-2}\right]$ & $-6,732$ & $-3,651$ & $-8,397$ & $-3,517$ & $-1,272$ & $-2,44$ & $-3,64$ & $-17,41$ & $-7,241$ \\
\hline$Y_{\delta_{a}}\left[\mathrm{~m} / \mathrm{s}^{2}\right]$ & $-0,7922$ & $-0,2423$ & $-0,7343$ & $-0,1457$ & $-0,1847$ & $-0,1268$ & $-0,2719$ & $-5,291$ & $-2,42$ \\
\hline$L_{\delta_{a}}\left[\mathrm{~s}^{-2}\right]$ & 17,27 & 8,757 & 21,27 & 7,998 & 1,875 & 5,09 & 8,76 & 37,48 & 16,88 \\
\hline$N_{\delta_{a}}\left[\mathrm{~s}^{-2}\right]$ & 0,334 & $-0,246$ & 0,479 & $-0,139$ & $-0,024$ & $-0,1087$ & $-0,1641$ & 1,462 & 0,414 \\
\hline
\end{tabular}

Tabela 4.2 - Derivadas látero-direcionais (dimensionais) (McRUER et al., 1973; SCHIMIDT, 1998).

As derivadas látero-direcionais fornecidas pela Tabela 4.2 foram usadas no modelo apenas para validá-lo, já que o foco deste trabalho é apenas o movimento longitudinal da aeronave. 


\begin{tabular}{|c|l|l|l|l|l|l|l|l|l||}
\hline DERIVADAS & CASO 1 & CASO 2 & CASO 3 & CASO 4 & CASO 5 & CASO 6 & CASO 7 & CASO 8 & CASO 9 \\
\hline$X_{u}\left[\mathrm{~s}^{-1}\right]$ & $-0,0160$ & $-0,0148$ & $-0,0129$ & $-0,0128$ & $-0,0826$ & $-0,01687$ & $-0,01482$ & $-0,0635$ & $-0,0353$ \\
\hline$X_{\alpha}\left[\mathrm{m} / \mathrm{s}^{2}\right]$ & $-0,5310$ & $-3,7978$ & $-1,1342$ & $-6,2819$ & $-2,1207$ & $-5,0172$ & $-4,7833$ & -13.8013 & -14.3378 \\
\hline$Z_{u}\left[\mathrm{~s}^{-1}\right]$ & $-0,156$ & $-0,160$ & $-0,104$ & $-0,114$ & $-0,26$ & $-0,1291$ & $-0,1518$ & $-0,135$ & $-0,120$ \\
\hline$Z_{\alpha}\left[\mathrm{m} / \mathrm{s}^{2}\right]$ & $-121,462$ & $-66,9341$ & $-158,160$ & $-66,5378$ & $-20,8669$ & $-5,0172$ & $-67,0438$ & -428.0916 & -178.8262 \\
\hline$M_{u}[\mathrm{~m} \cdot \mathrm{s}]^{-1}$ & 0,0013 & 0,0016 & 0,0013 & 0,0013 & 0,0095 & 0,0017 & 0,0015 & $-1094,2$ & $-575,8858$ \\
\hline$M_{\alpha}\left[\mathrm{s}^{-2}\right]$ & $-10,233$ & $-5,639$ & $-12,97$ & $-5,402$ & $-2,2746$ & $-3,6963$ & $-5,6597$ & $-35,96$ & $-14,99$ \\
\hline$M_{\dot{\alpha}}\left[\mathrm{s}^{-1}\right]$ & $-0,342$ & $-0,204$ & $-0,353$ & $-0,160$ & $-0,1441$ & $-0,1232$ & $-0,2039$ & $-0,858$ & $-0,389$ \\
\hline$M_{q}\left[\mathrm{~s}^{-1}\right]$ & $-1,151$ & $-0,670$ & $-1,071$ & $-0,484$ & $-0,48$ & $-0,389$ & $-0,670$ & $-1,934$ & $-0,876$ \\
\hline$X_{\delta_{e}}\left[\mathrm{~m} / \mathrm{s}^{2}\right]$ & 1,2619 & 0,7772 & 1,2253 & 0,8199 & 0 & 0 & 0 & -50976 & -14700 \\
\hline$Z_{\delta_{e}}\left[\mathrm{~m} / \mathrm{s}^{2}\right]$ & $-12,9723$ & $-6,9921$ & $-17,3797$ & $-7,2329$ & $-2,1549$ & $-4,8189$ & $-6,9921$ & -31.3883 & -13.07592 \\
\hline$M_{\delta_{e}}\left[\mathrm{~s}^{-2}\right]$ & $-13,73$ & $-7,40$ & $-19,46$ & $-8,10$ & $-2,21$ & $-5,26$ & $-7,40$ & $-33,81$ & $-14,8$ \\
\hline$Z_{\dot{\alpha}}$ & 0 & 0 & 0 & 0 & 0 & 0 & 0 & 0 & 0 \\
\hline$Z_{q}$ & 0 & 0 & 0 & 0 & 0 & 0 & 0 & 0 & 0 \\
\hline
\end{tabular}

Tabela 4.3 - Derivadas longitudinais (dimensionais) (McRUER et al., 1973; SCHIMIDT, 1998).

\subsection{Apresentação do envelope de vôo a ser identificado}

Um esquema do envelope de vôo a ser identificado está representado na Figura 4.1. Os pontos em vermelho representam as altitudes e Mach para cada uma das condições de vôo conhecidas. Será simulado o comportamento da aeronave nestes pontos, usando várias entradas diferentes e alguns destes conjuntos de respostas, especificamente 4 deles, serão usados para treinamento das redes e os outros serão usados em testes de generalização, ou seja, serão apresentadas respostas da aeronave correspondentes a estes dados, para ver se ela consegue identificar estas respostas.

Foi simulado o comportamento longitudinal e lateral-direcional da aeronave para as nove posições do envelope de vôo apresentado na Figura 4.1 com as derivadas apresentadas nas Tabelas 4.2 e 4.3 anteriores, usando o modelo matemático não linear apresentado no Capítulo 3. Como se pode observar, há duas condições de vôo a Mach 0,4 e altitude de 4.572 metros. Porém estes dados foram retirados de diferentes literaturas e possuem pequenas diferenças em alguns valores de derivadas, como se pôde observar nas Tabelas 4.1, 4.2 e 4.3 apresentadas anteriormente. 


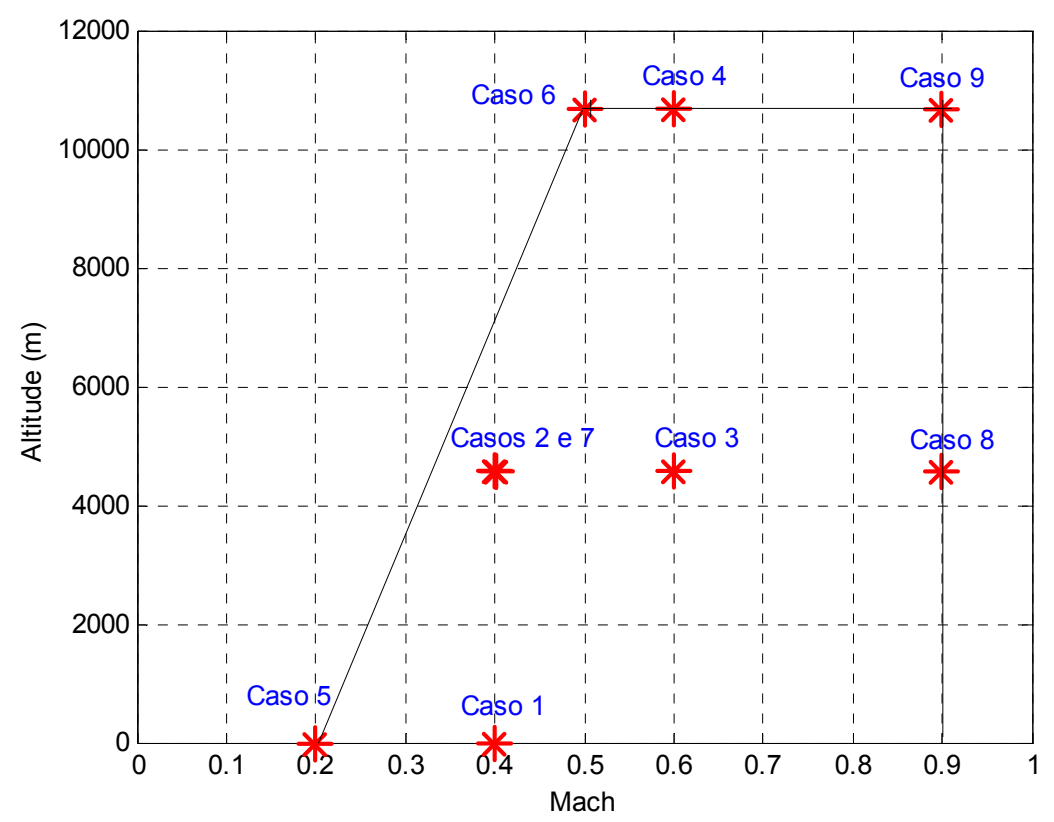

Figura 4.1. Esquema do envelope de vôo a ser identificado.

As derivadas de estabilidade e de controle apresentadas foram usadas somente depois de terem sido feitas as compatibilizações de unidades com as apresentadas em ETKIN \& REID, (1996), como dito anteriormente.

\subsubsection{Simulação da dinâmica longitudinal da aeronave}

Os conjuntos de dados correspondentes a cada um dos casos, foram substituídos no modelo matemático apresentado no Capítulo 3 e simulados usando o Simulink. Serão apresentados alguns dos resultados da simulação da dinâmica não linear longitudinal da aeronave após ter sofrido entrada de profundor do tipo degrau com amplitude de 2 graus, iniciado no tempo 20 segundos com duração de 5 segundos. A Figura 4.2 apresenta as respostas obtidas de velocidade horizontal e a Figura 4.3 apresenta as respostas de velocidade vertical da aeronave para cada um dos casos. A Figura 4.4 foi plotada apenas até 50 segundos, pois é nesse intervalo de tempo que ocorrem as maiores variações. 


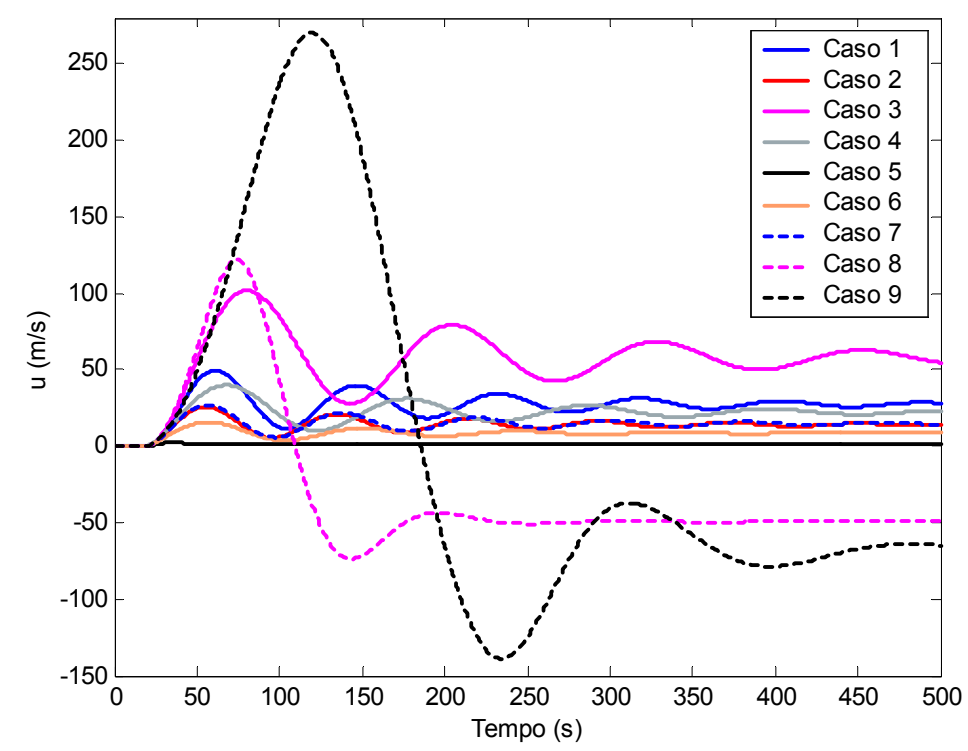

Figura 4.2. Respostas de velocidade horizontal obtidas em simulação da aeronave para as 9 condições de vôo apresentadas.

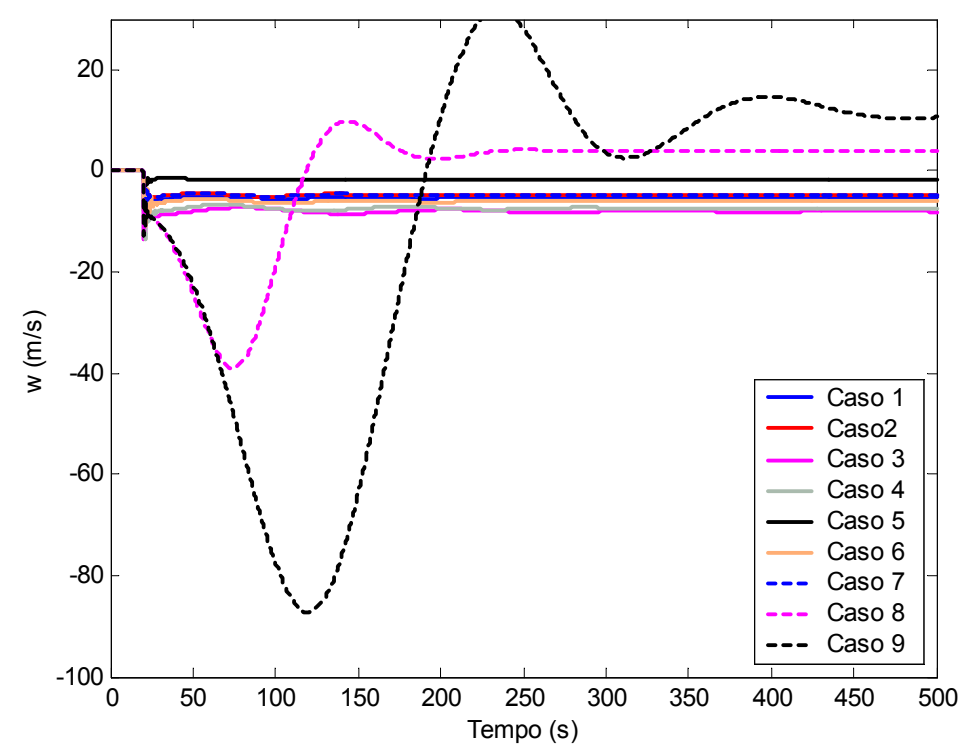

Figura 4.3. Respostas de velocidade vertical obtidas em simulação da aeronave.

A maior variação na velocidade vertical foi logo depois de ter sido dada a entrada como se pôde observar da Figura 4.3 e então, para poder observar melhor a variação de $w$, foi construído um gráfico mostrando apenas o intervalo de 15 a 60 segundos da resposta de $w$, mostrado na Figura 4.4 . 


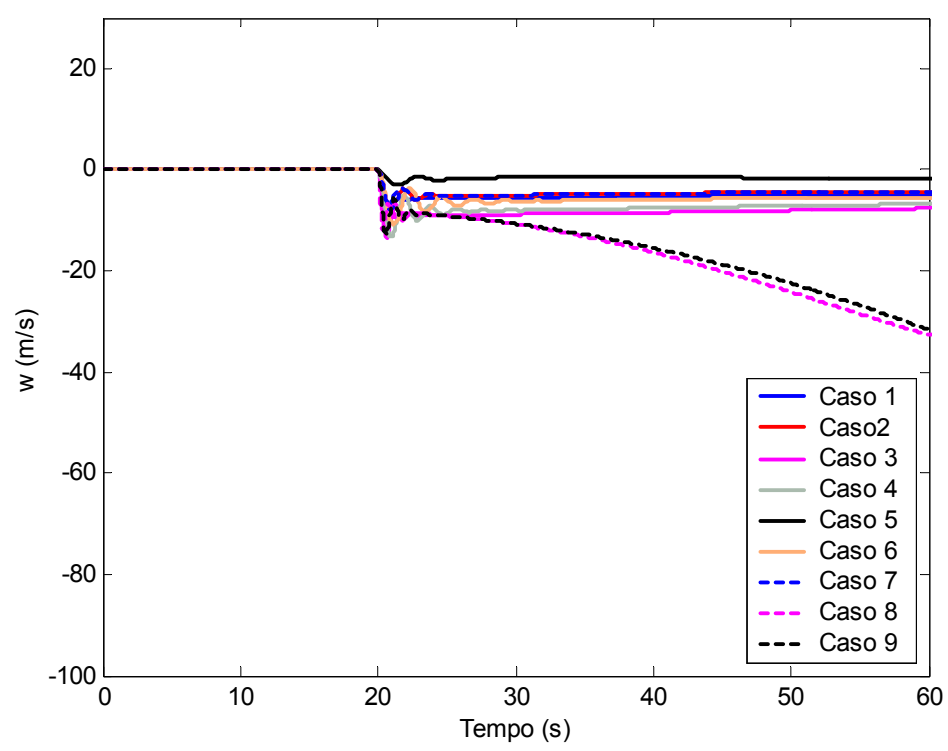

Figura 4.4. Respostas de velocidade verticais obtidas em simulação num intervalo menor de tempo.

A Figura 4.5 apresenta as respostas da velocidade de arfagem $q$ para os casos simulados.

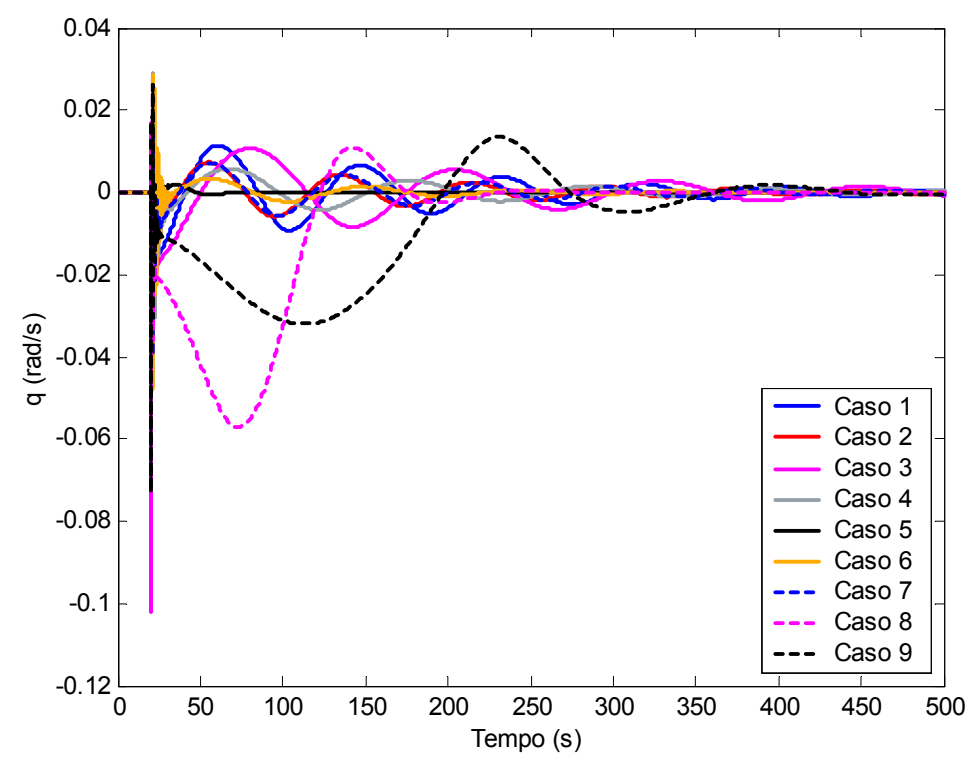

Figura 4.5. Respostas de $q$ obtidas em simulação.

Novamente, para facilitar a visualização das respostas próximas ao tempo no qual foi dada a entrada, foi plotado o gráfico com as respostas no intervalo de tempo de 18 até 30 segundos apenas. Este gráfico está mostrado na Figura 4.6. 


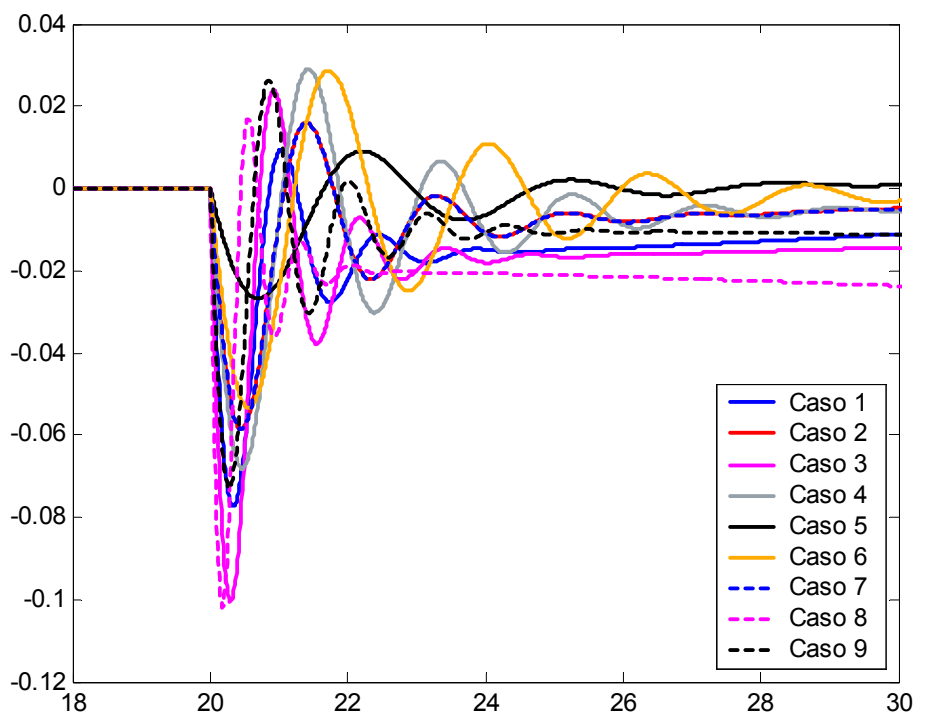

Figura 4.6. Respostas de $q$ obtidas em simulação.

A Figura 4.7 mostra o gráfico do ângulo de arfagem $\theta$ para os casos simulados.

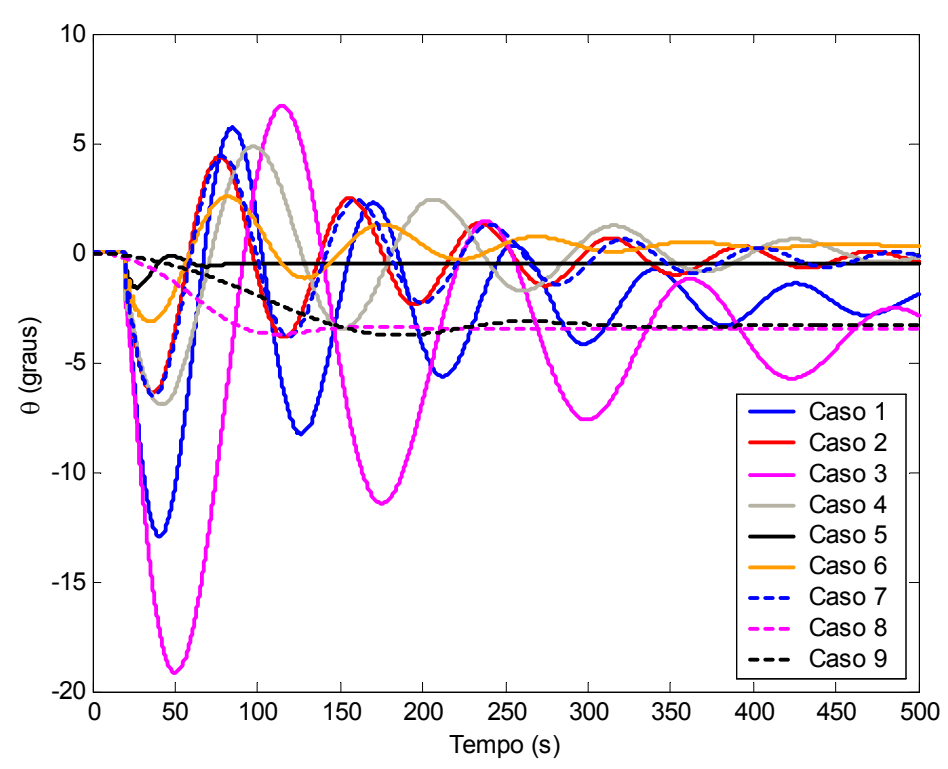

Figura 4.7. Respostas de $\theta$ (ângulo de arfagem) obtidas em simulação.

Após as simulações realizadas, segundo dados obtidos das variáveis de estado e segundo os gráficos mostrados anteriormente, pode-se observar que o comportamento dinâmico da aeronave corresponde ao movimento convergente oscilatório, ou seja, problemas de instabilidade não ocorrem. Porém, pode-se observar também, nas Figuras 4.2 e 4.3 que houve um grande aumento das velocidades horizontal e vertical da aeronave nas condições referentes aos casos 8 e 
9, fato ocorrido devido à aeronave se encontrar em alta velocidade, precisamente, voando a Mach 0,9 , velocidade tal em que ela se torna mais sensível.

\subsubsection{Identificação da dinâmica longitudinal}

Para conseguir os conjuntos de dados para treinar as redes neurais, foram feitas três simulações usando os dados do caso 5 , três simulações usando dados do caso 6 , três simulações para o caso 8 e três simulações do caso 9, usando apenas entrada degrau nos profundores com valores variando até 12 graus. Para treinamento foram escolhidos os casos 5, 6, 8 e 9 pois representam pontos extremos do envelope de vôo. O modelo foi simulado sofrendo entrada degrau no profundor por ser altamente não linear, ou seja, se a rede entendesse a resposta correspondente a esta entrada entenderia a resposta a qualquer outra entrada aplicada.

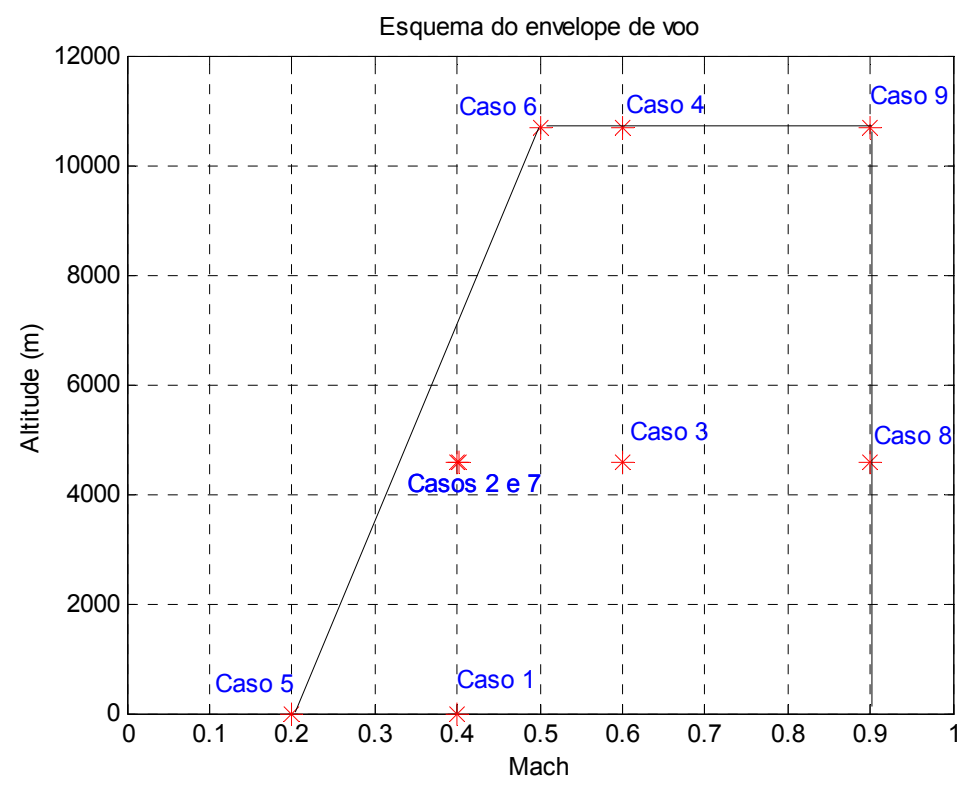

Figura 4.8. Esquema representativo dos pontos do envelope de vôo simulados.

\subsubsection{Abordagem sobre as redes neurais usadas na identificação}

A princípio pensou-se em implementar 3 redes neurais, uma para identificar a velocidade horizontal $u$, uma para identificar a velocidade vertical $w$ e outra para identificar a velocidade angular de arfagem $q$. Ou seja, a idéia era identificar todas as saídas separadamente, pois aparentemente teria menor custo computacional. 
Foi implementada uma rede do tipo recorrente para identificar a velocidade horizontal da aeronave. Para a montagem da matriz de entrada para a rede neural, foram usados 3 conjuntos de dados obtidos em simulação para os casos 5, 6, 8 e 9, todos usando entrada degrau dada no tempo 20s com diferentes valores nos profundores associadas ao número de Mach e às altitudes correspondentes do envelope de vôo. Como explicado anteriormente, foram dadas duas entradas para a rede neural: uma dinâmica que era o sinal degrau aplicado ao profundor e duas entradas estáticas que eram valores de Mach e densidade do ar correspondente ao caso simulado.

A rede que melhor apresentou resultados tinha 3 camadas de neurônios, cada entrada com 2 atrasos, 10 neurônios na camada intermediária e 1 neurônio na camada de saída. Foram obtidos resultados pouco razoáveis em teste de generalização, sendo que ela não identificou a velocidade para o caso 4. Estes primeiros resultados encontrados foram dentro de um envelope de vôo menor, sem as duas condições a Mach 0,9 e foram mostrados em SOUZA et al. (2005).

Em seguida, já com as duas condições de vôo a Mach 0,9 inclusas no envelope de vôo, usou-se uma rede neural artificial recorrente, colocando laços de realimentação da camada de saída para a camada de entrada, mas houve pequena melhora nos resultados, concluindo-se então que a rede não havia capturado a dinâmica da aeronave.

A idéia foi então montar uma única rede neural representativa de toda a aeronave, isto é, com entrada de ângulo de profundor e contendo as 3 saídas $u, w$ e $q$. A rede implementada continuou sendo recorrente e com 3 camadas de neurônios. Vários testes foram então realizados. A princípio, foram colocados 4 atrasos em cada entrada e cada saída, 12 neurônios na camada intermediária e 3 neurônios na camada de saída. Os resultados obtidos no treinamento foram bastante satisfatórios.

Objetivando diminuir o custo computacional, primeiramente o número de atrasos foi reduzido de 4 para 3 e depois para 1 e ainda se pôde observar resultados muitos bons. Para verificar os resultados do treinamento, testes com outros resultados de simulação foram realizados, e confirmaram que a rede havia mesmo capturado a dinâmica do sistema. Concluiu-se então que, para este problema, não era necessário mais que um atraso. Testes variando o número de neurônios na camada intermediária também foram realizados. Pôde-se verificar que diminuindo de 12 para 9 neurônios os resultados se mostraram bastante satisfatórios. Depois de todos estes testes, foi escolhida então uma rede, recorrente, com três camadas de neurônios, 2 atrasos na entrada e 2 atrasos para cada saída, 9 neurônios na camada intermediária e 3 neurônios na camada de saída. A 
Figura 4.9 a seguir apresenta um diagrama de blocos representativo da rede neural usada na identificação.

No diagrama de blocos apresentado na Figura 4.9, estão representados $u(t) \equiv \delta_{e}$ que foi a entrada dinâmica aplicada ao profundor juntamente com seus respectivos atrasos, as entradas fixas altitude $(h)$ e Mach $(M)$ associadas à entrada dinâmica, $y_{1}(t), y_{2}(t)$ e $y_{3}(t)$ representando as saídas de velocidade horizontal $u$, velocidade vertical $w$ e velocidade de arfagem $q$ todas com seus respectivos atrasos. A rede foi treinada durante 500 épocas, pois depois disto não houve variação do erro, e como pode-se verificar na Figura 4.10, o resultado de treinamento foi bastante satisfatório, atingindo ordem de $10^{-4}$.

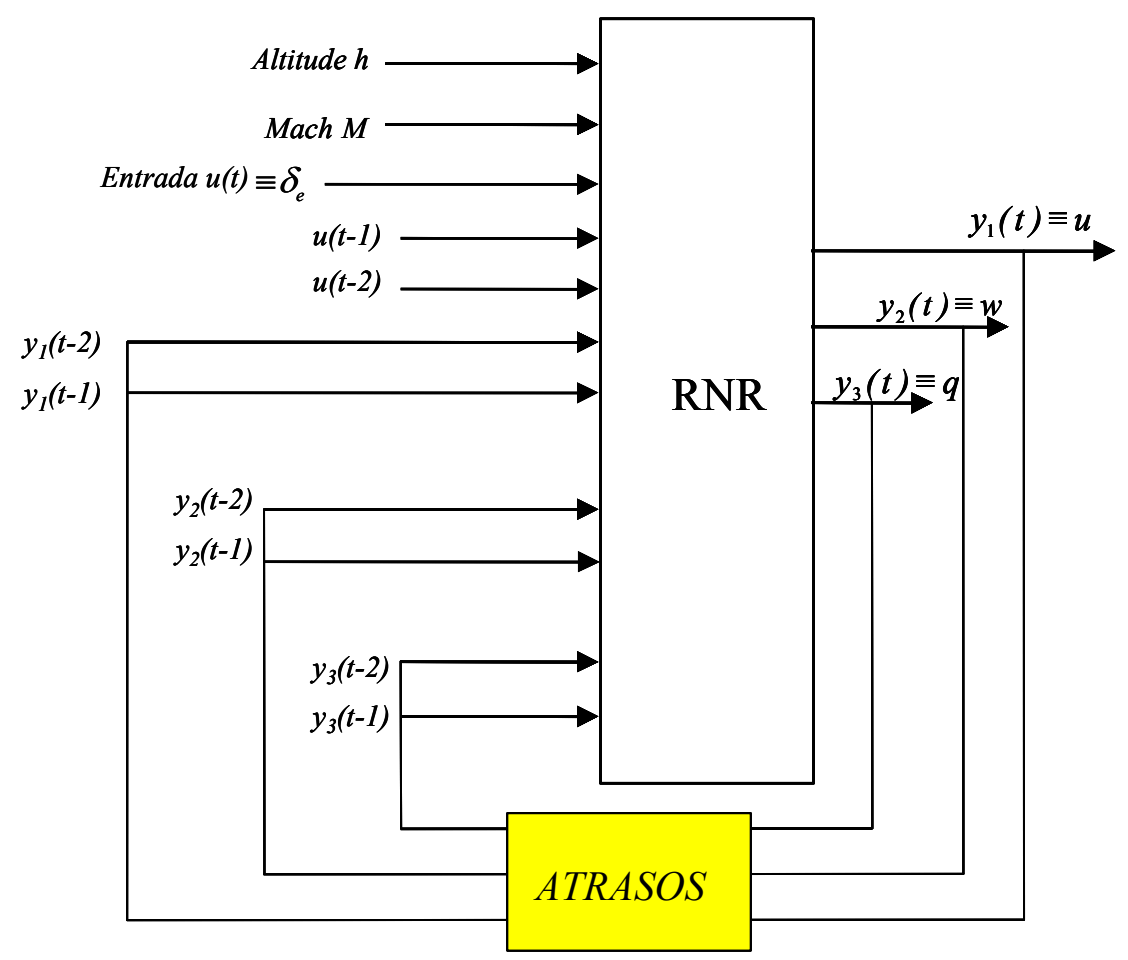

Figura 4.9. Esquema representativo da rede neural recorrente usada na identificação. 


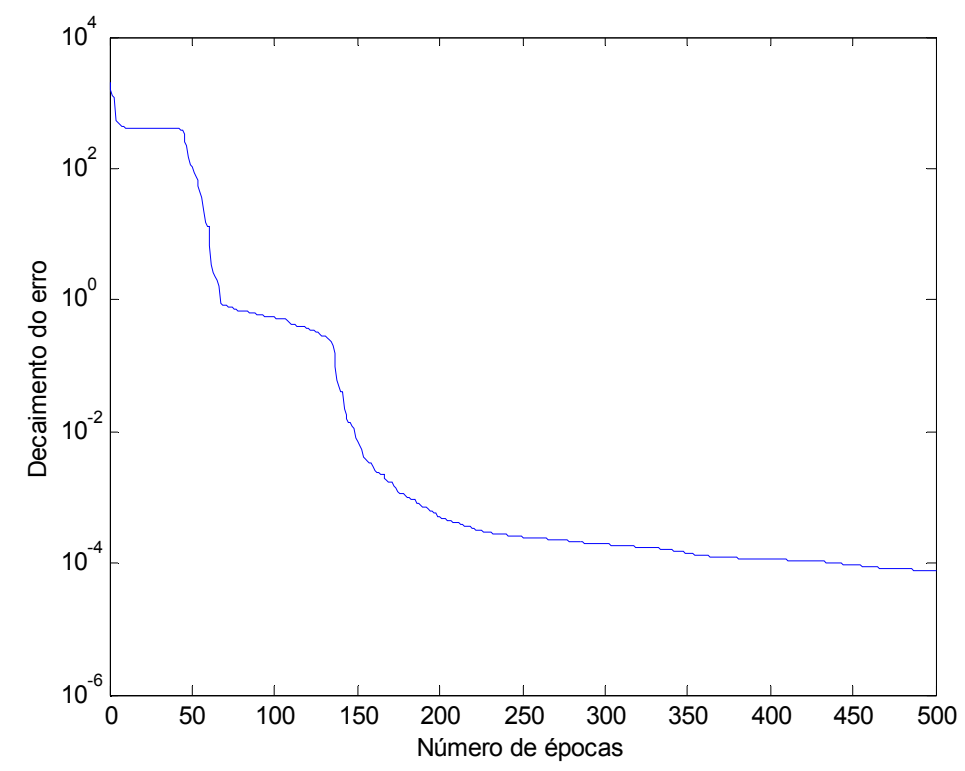

Figura 4.10. Decaimento do erro durante o treinamento da rede.

Pôde-se concluir então que as redes com a entrada degrau associada a cada saída separadamente, não eram representativas da dinâmica da aeronave enquanto que a rede com a entrada degrau aplicada ao profundor associada a todas as saídas apresentadas de uma só vez era representativa do comportamento dinâmico da aeronave em qualquer ponto daquele envelope. Como dito anteriormente, a rede foi treinada simultaneamente com os dados dos Casos 5, 6, 8 e 9, usando como entradas fixas os valores de altitude e Mach e uma entrada dinâmica que foi a entrada degrau no profundor como dito anteriormente. Para treiná-la, foi usado o algoritmo Backpropagation, com a técnica de otimização de Levenberg-Marquardt.

\subsubsection{Resultados da identificação das respostas da aeronave dentro do envelope de vôo}

Depois de treinar a rede neural, foi salvo o conjunto de pesos e bias num arquivo para ser usado em testes de generalização. Primeiramente serão apresentados resultados de treinamento da RNA.

\subsection{Resultados de testes realizados com a RNA para verificação do treinamento}

Foram simuladas três condições de vôo usando os dados correspondentes aos casos onde a rede foi treinada, porém usando entradas nos profundores diferentes das quais foram usadas para 
treinamento. A seguir serão apresentadas nas Figuras 4.11, 4.13 e 4.15 os gráficos de respostas deste teste para o Caso 5 .

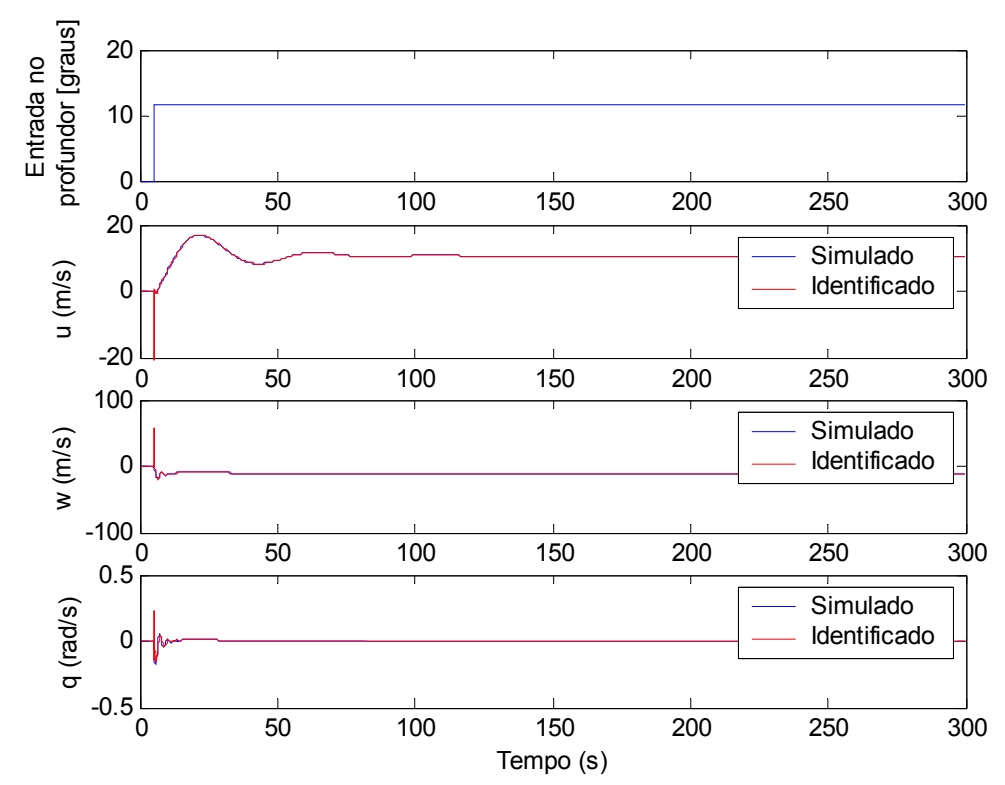

Figura 4.11 Resultado gerado pela RNA referente ao Caso 5 com entrada degrau de $12^{\circ}$.

Como se pode observar na Figura 4.11, nas respostas de $w$ e $q$ o movimento de fugóide quase não aparece, mas o de período curto é perceptível. Já em $u$ ocorre o inverso. Para uma melhor visualização do movimento de curto período, foram plotadas as respostas de $w$ e $q$ na mostradas na Figura 4.12 no tempo de até 50 segundos.
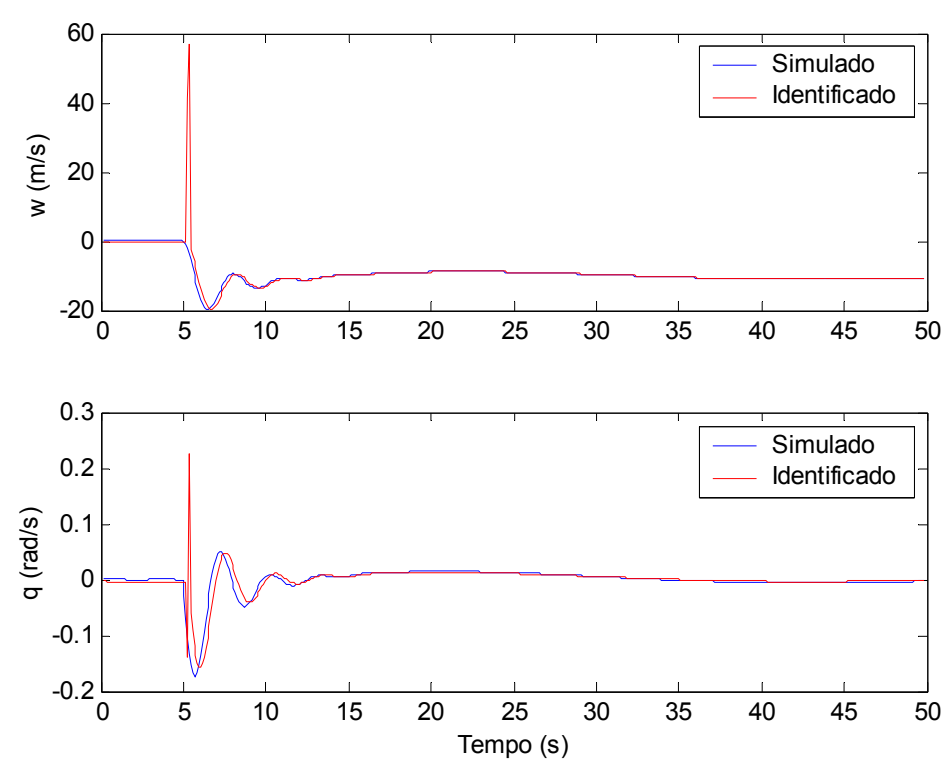

Figura 4.12. Respostas de $w$ e $q$ apresentadas na Figura 4.11 até 50 segundos. 
As Figuras 4.11 e 4.12 mostram que a rede neural identificou satisfatoriamente, porém houve a presença de um pico no instante que foi dada a entrada degrau. Para verificar se era problema numérico, foi usado como entrada um sinal do tipo rampa num intervalo de 2 segundos, representando um sinal mais próximo do real. Como mostra a Figura 4.13, o pico não ocorreu novamente, concluindo-se que pode ser problema numérico. Também, como o sinal degrau é irreal, pode-se dizer que o resultado não afeta a metodologia apresentada.

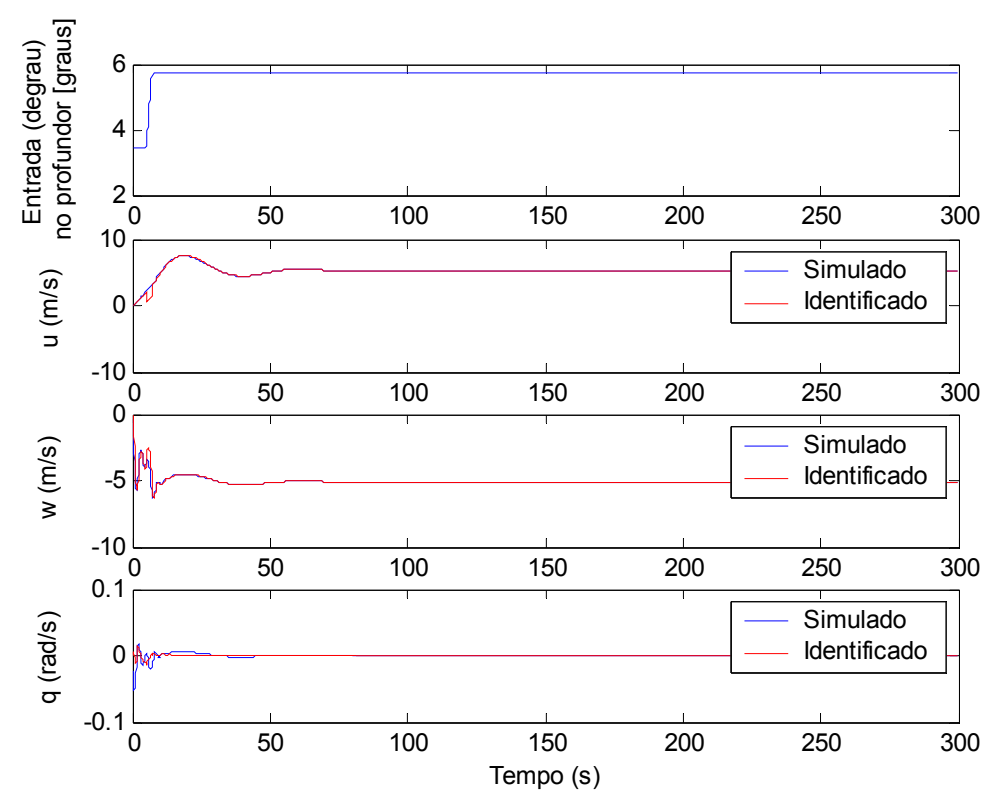

Figura 4.13 Resultado gerado pela RNA referente ao Caso 5 com entrada rampa.

Para todos os resultados deste primeiro teste, analogamente ao que foi feito com as Figuras 4.11 e 4.12, serão geradas figuras mostrando variações de $w$ e $q$ no intervalo de 0 até 50 segundos apenas, pois depois de 10s já não ocorrem mais variações. 


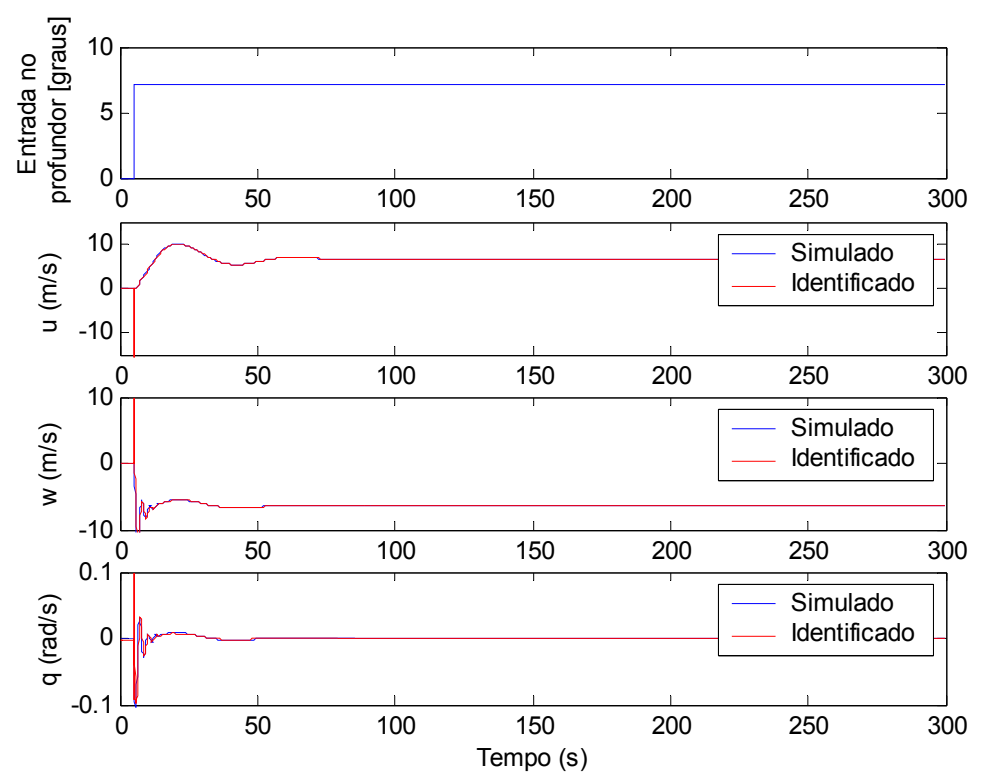

Figura 4.14. Resultado gerado pela RNA referente ao Caso 5 com entrada $7,2^{\circ}$.
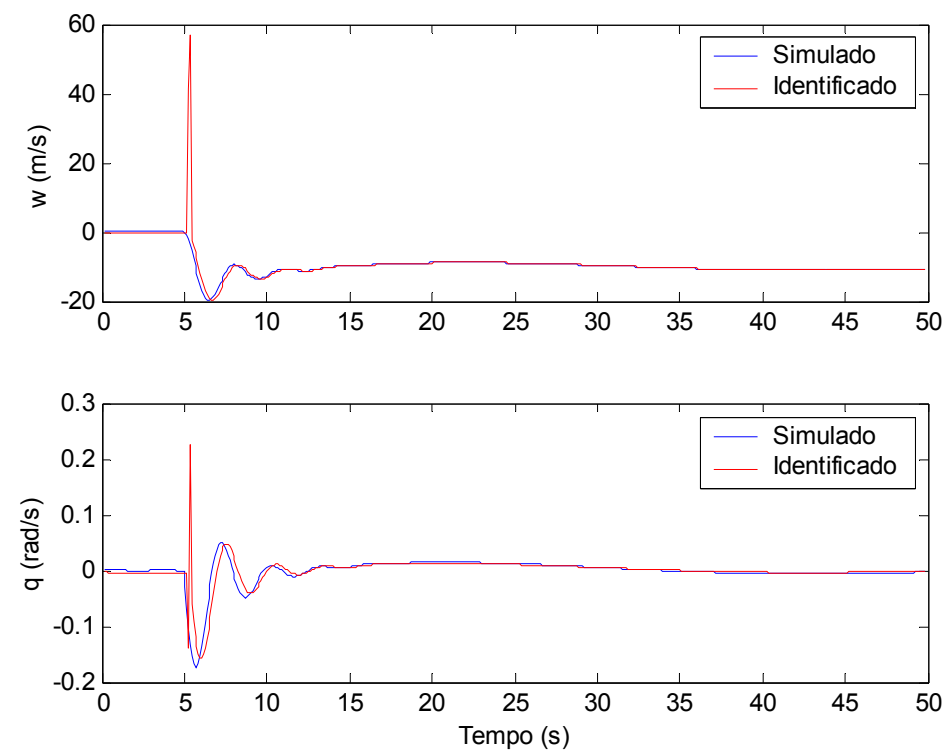

Figura 4.15. Respostas de $w(t)$ e $q(t)$ apresentadas na Figura 4.13 até 50 segundos. 

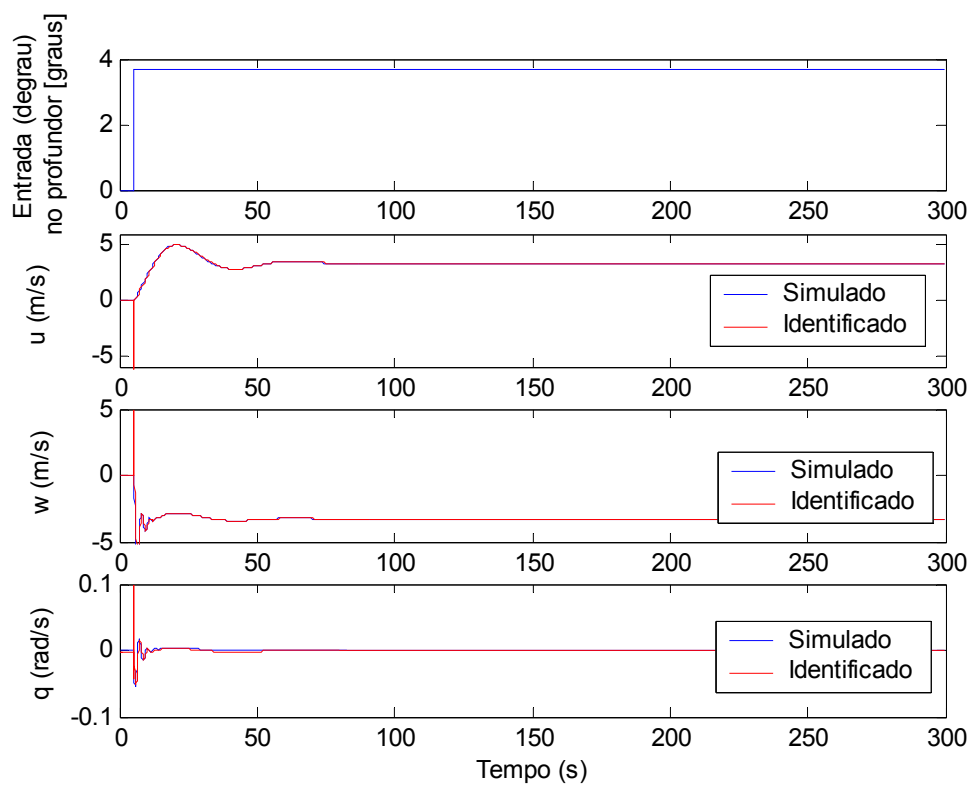

Figura 4.16. Resultado gerado pela RNA referente ao Caso 5 com entrada de $3,8^{\circ}$ no profundor.
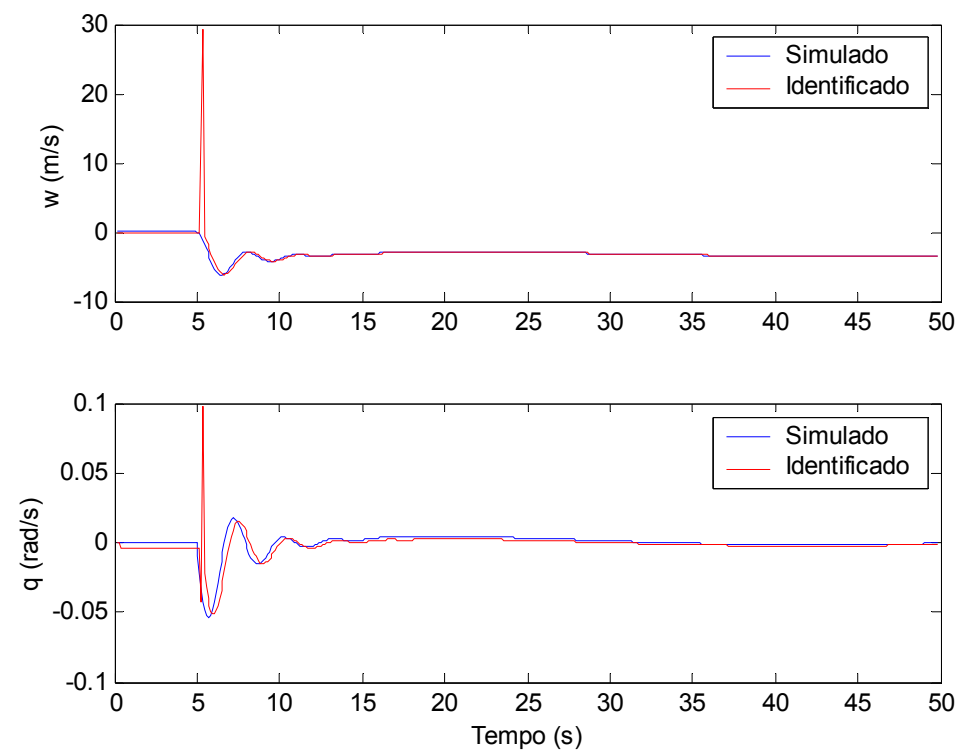

Figura 4.17. Respostas de $w(t)$ e $q(t)$ apresentadas na Figura 4.16 até 50 segundos.

A seguir serão apresentadas nas Figuras 4.18, e 4.20 os gráficos de respostas deste teste para simulações usando dados do caso 6, usando entradas diferentes das usadas em treinamento. 


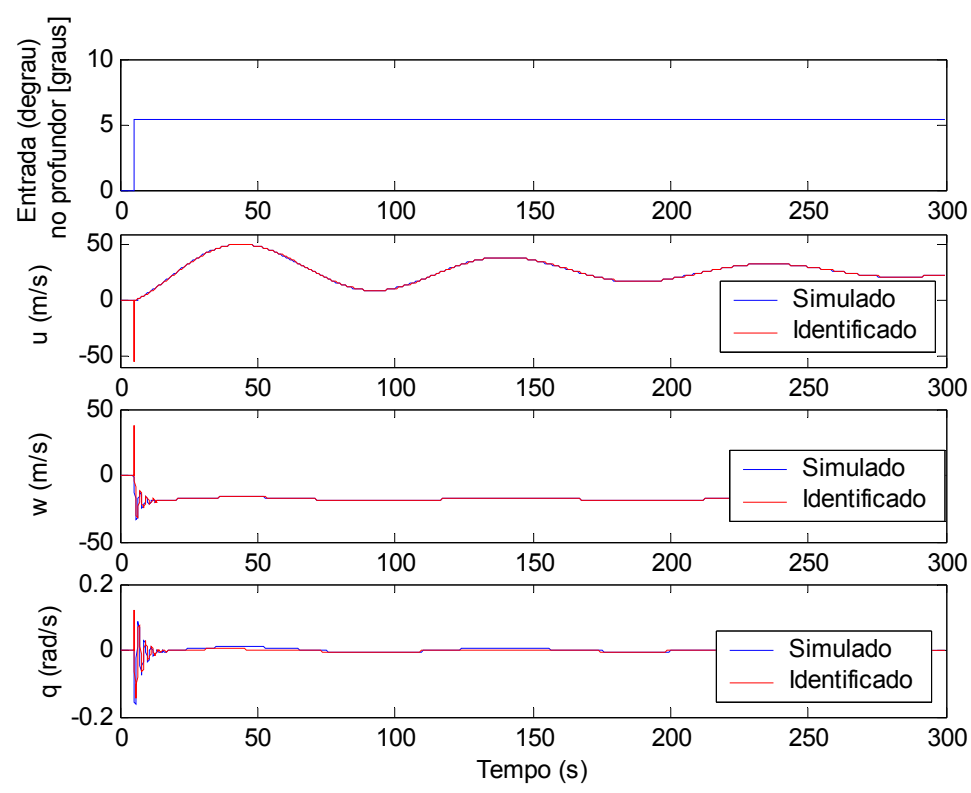

Figura 4.18. Resultado gerado pela RNA referente ao Caso 6 com entrada degrau de $5,1^{\circ}$ no profundor.
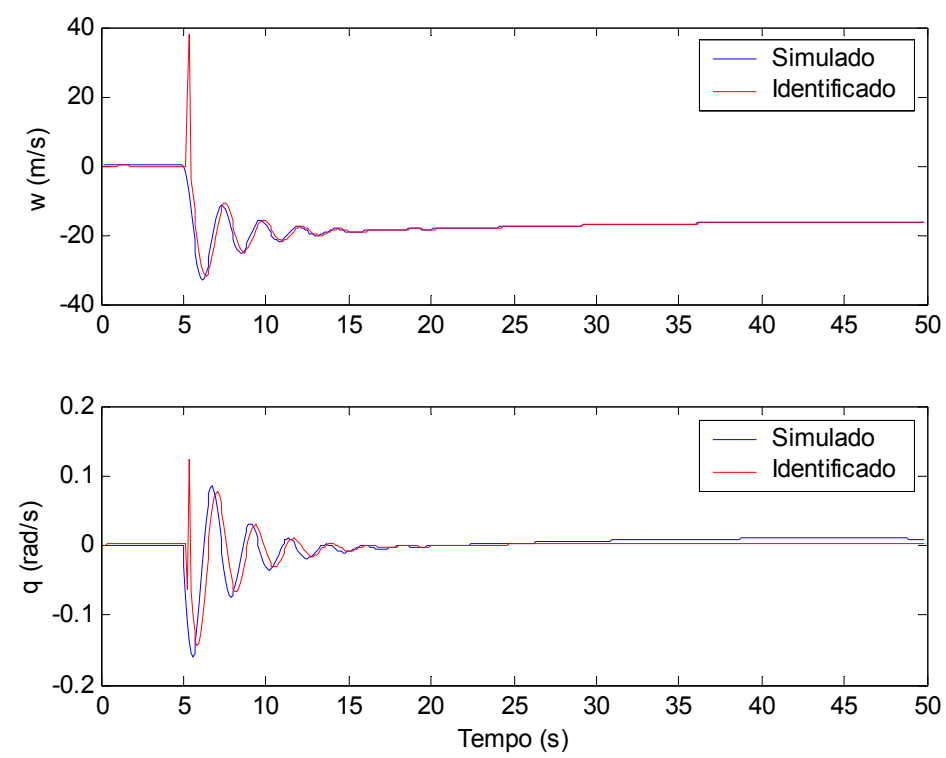

Figura 4.19. Respostas de $w(t)$ e $q(t)$ apresentadas na Figura 4.18 até 50 segundos. 


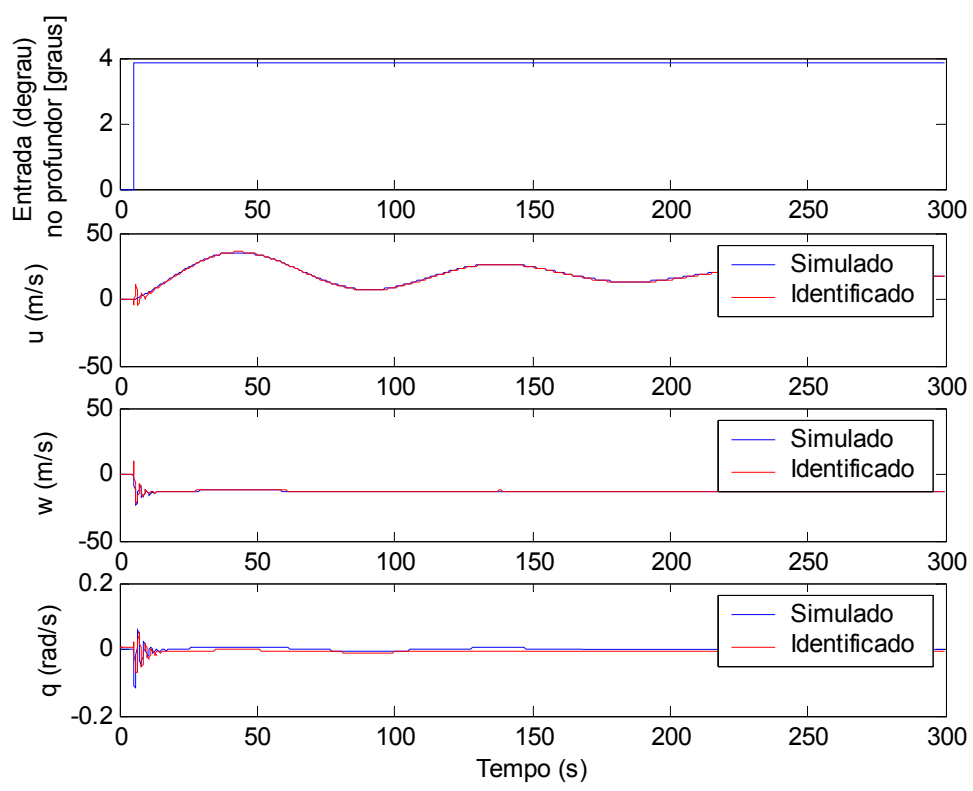

Figura 4.20. Resultado gerado pela RNA referente ao Caso 6 com entrada degrau de $3,8^{\circ}$ no profundor.
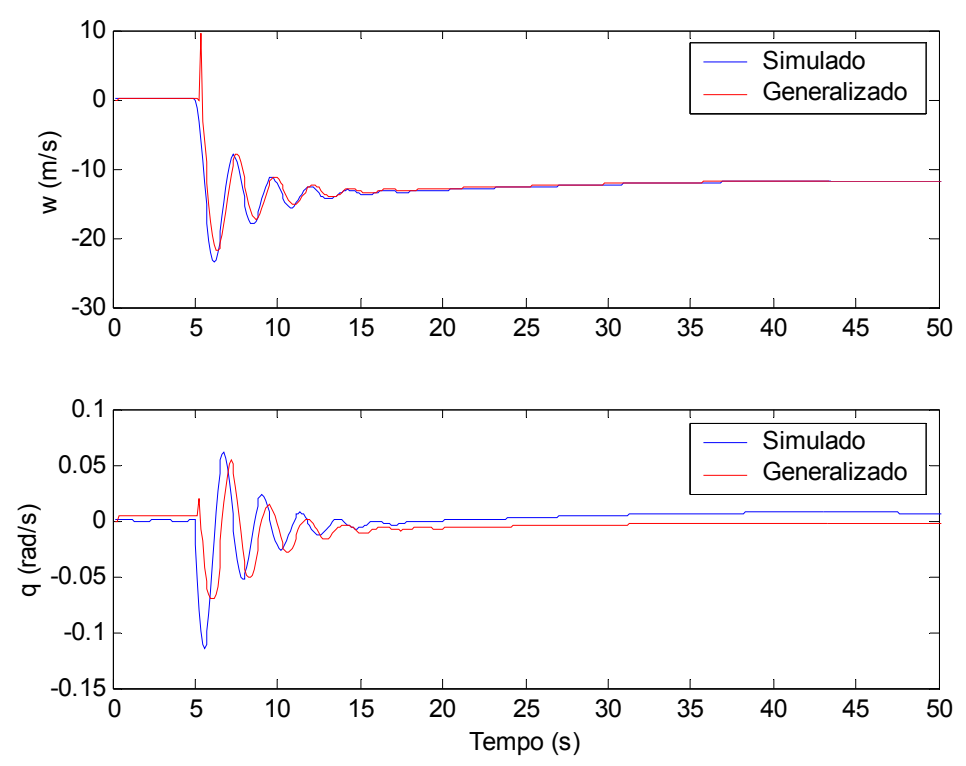

Figura 4.21. Respostas de $w(t)$ e $q(t)$ apresentadas na Figura 4.20 até 50 segundos.

Analogamente, nas Figuras 4.22, 4.24 e 4.26 são apresentados os gráficos de respostas deste teste para simulações usando dados do Caso 8, um dos casos no qual a aeronave se encontra em regime transônico. Poderá ser observado que nesta condição as respostas possuem maior amortecimento que nas outras. 


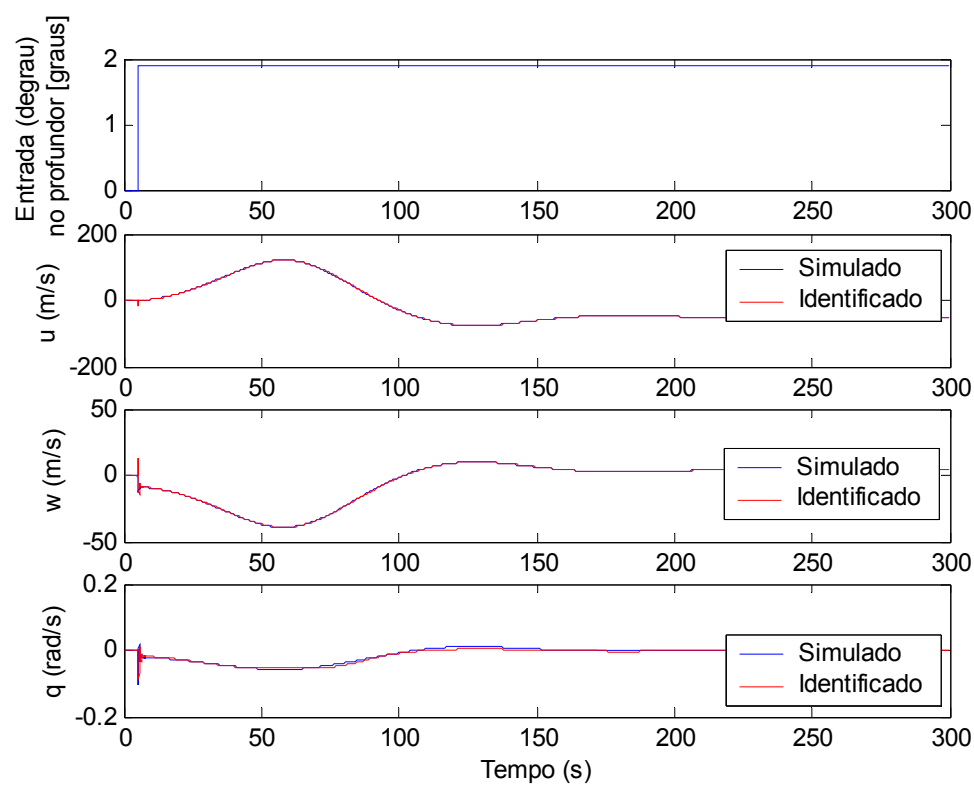

Figura 4.22. Resultado gerado pela RNA referente ao Caso 8 com entrada degrau de $1,9^{\circ}$ no profundor.
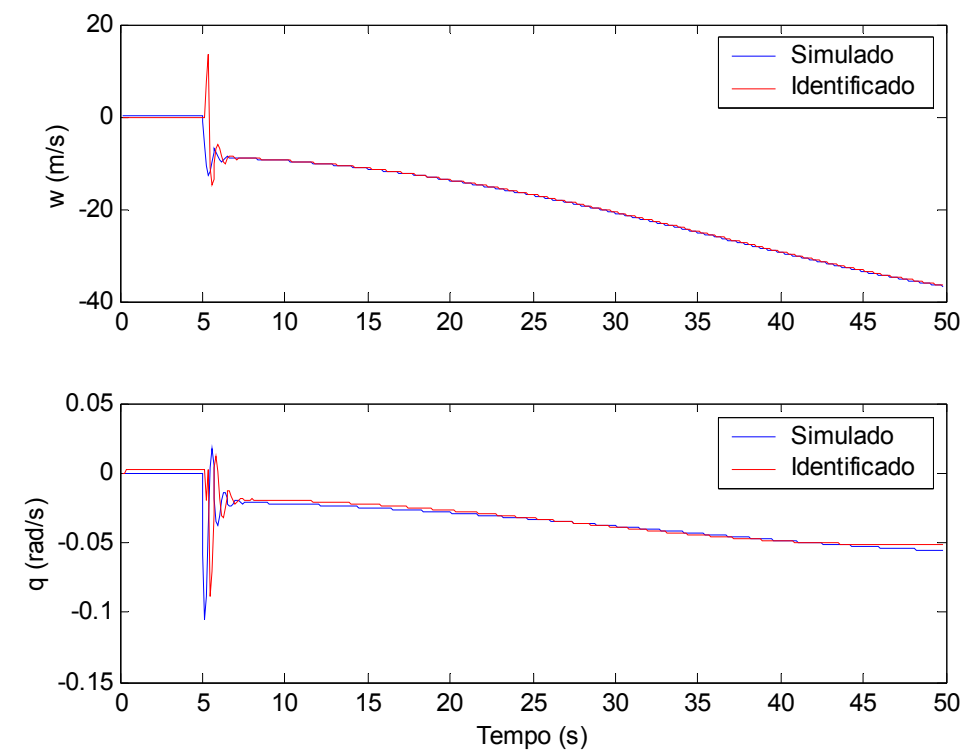

Figura 4.23. Respostas de $w(t)$ e $q(t)$ apresentadas na Figura 4.22 até 50 segundos. 


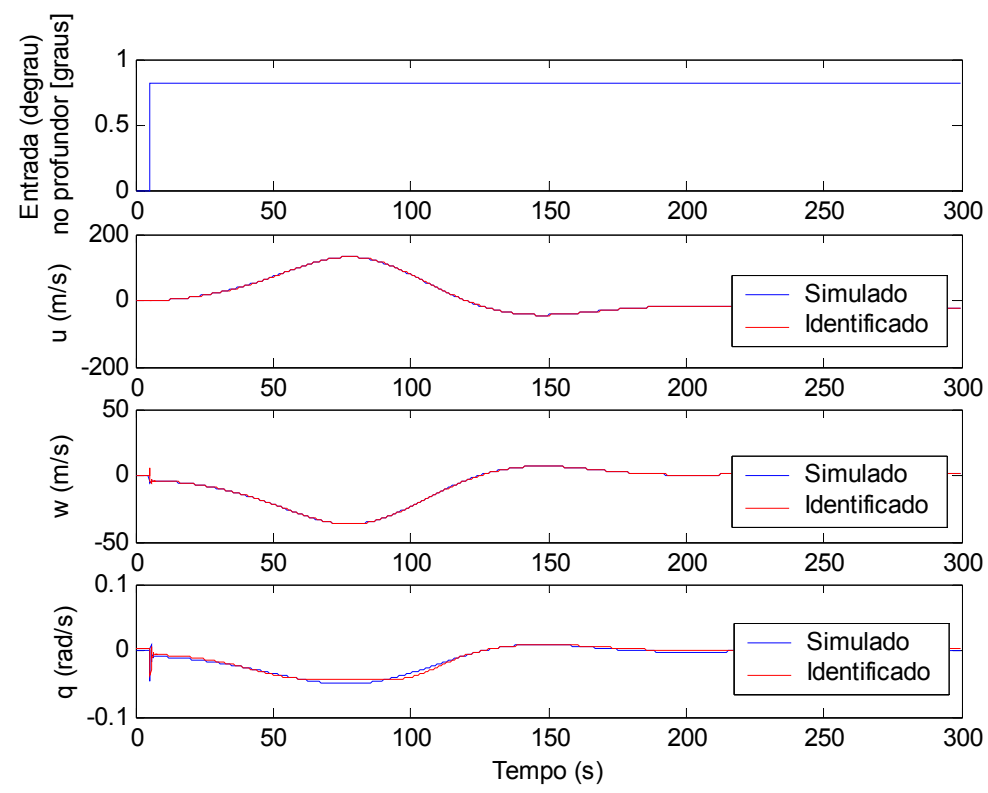

Figura 4.24 Resultado gerado pela RNA referente ao Caso 8 com entrada degrau de $0,8^{\circ}$ no profundor.
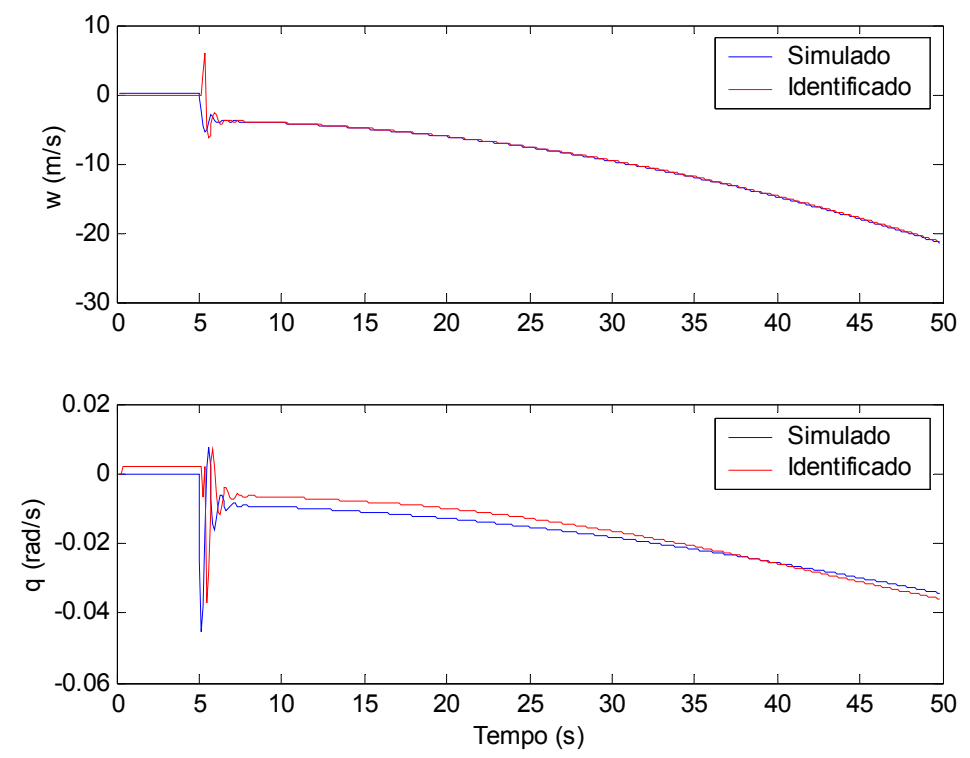

Figura 4.25. Respostas de $w(t)$ e $q(t)$ apresentadas na Figura 4.24 até 50 segundos. 


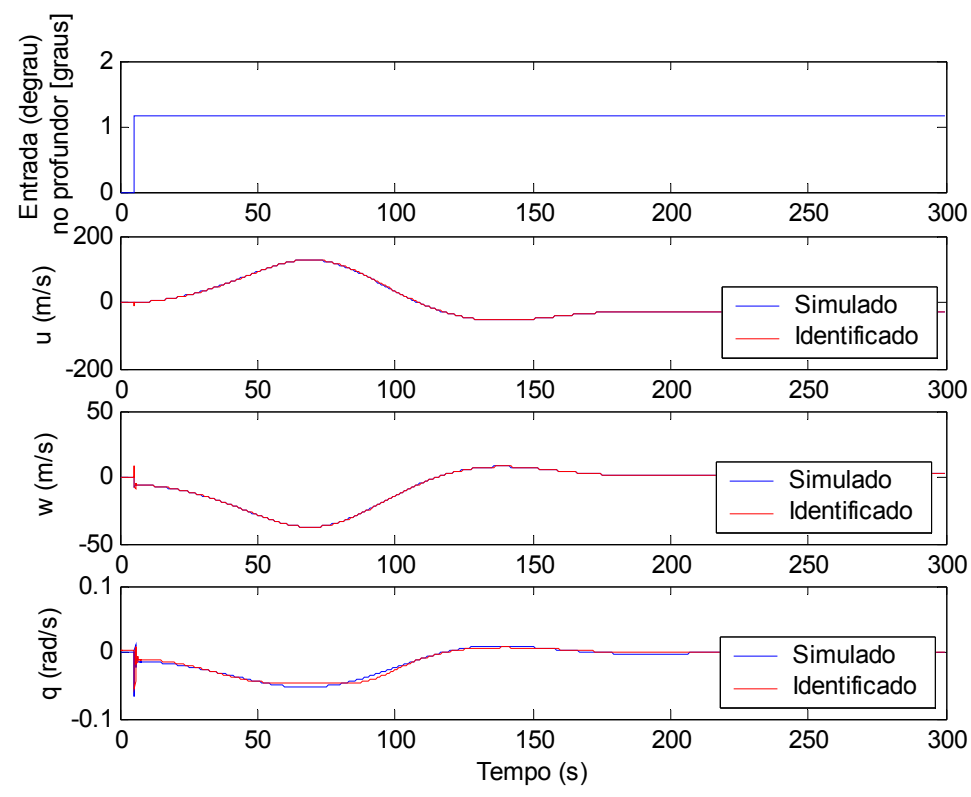

Figura 4.26 Resultado gerado pela RNA referente ao Caso 8 com entrada degrau de $1,2^{\circ}$ no profundor.
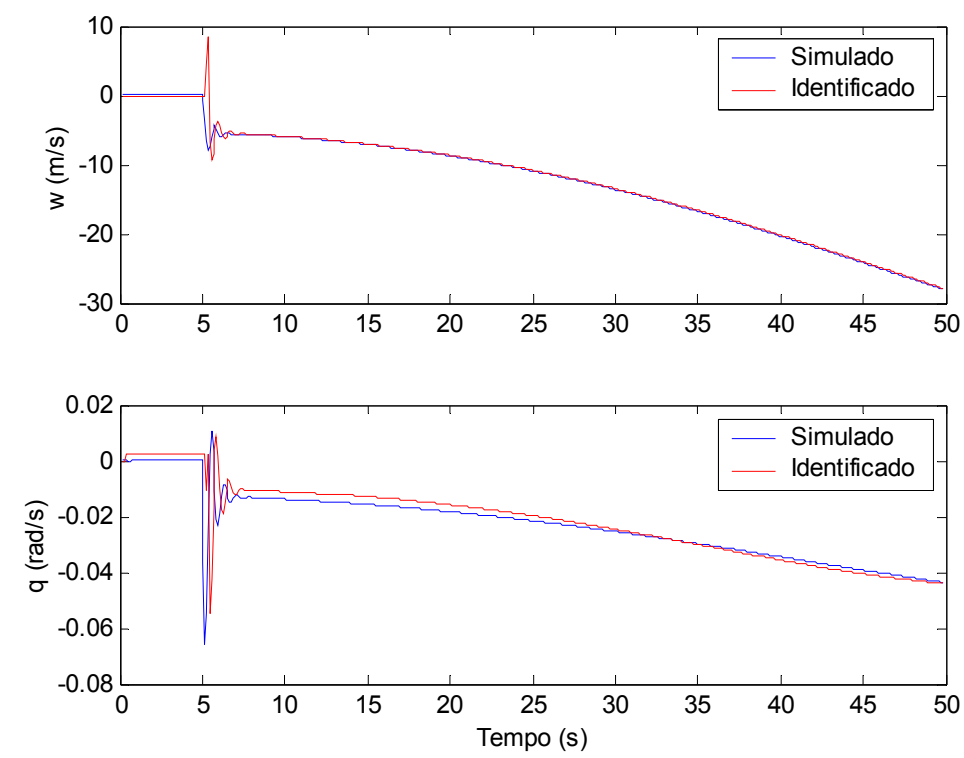

Figura 4.27. Respostas de $w(t)$ e $q(t)$ apresentadas na Figura 4.26 até 50 segundos.

Finalmente serão apresentados resultados de testes realizados usando dados do Caso 9, último dos quatro casos usados durante treinamento da rede neural artificial, observando que neste caso a aeronave também se encontra em regime de vôo transônico. 


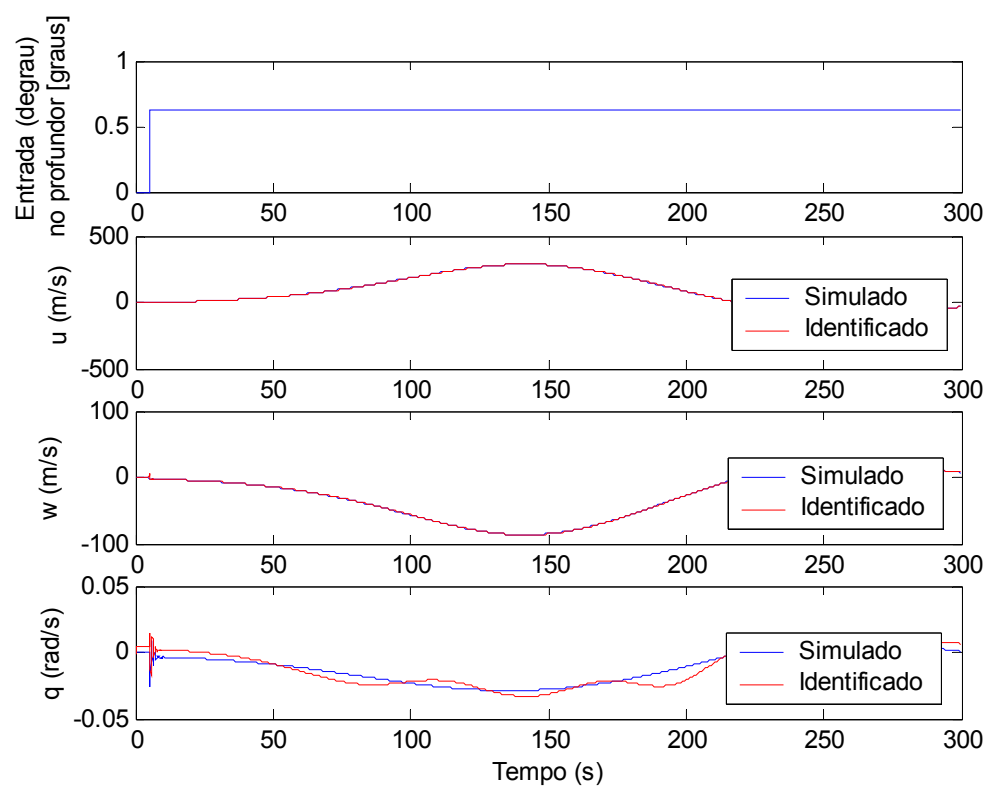

Figura 4.28 Resultado gerado pela RNA referente ao Caso 9 com entrada degrau de $0,7^{\circ}$ no profundor.
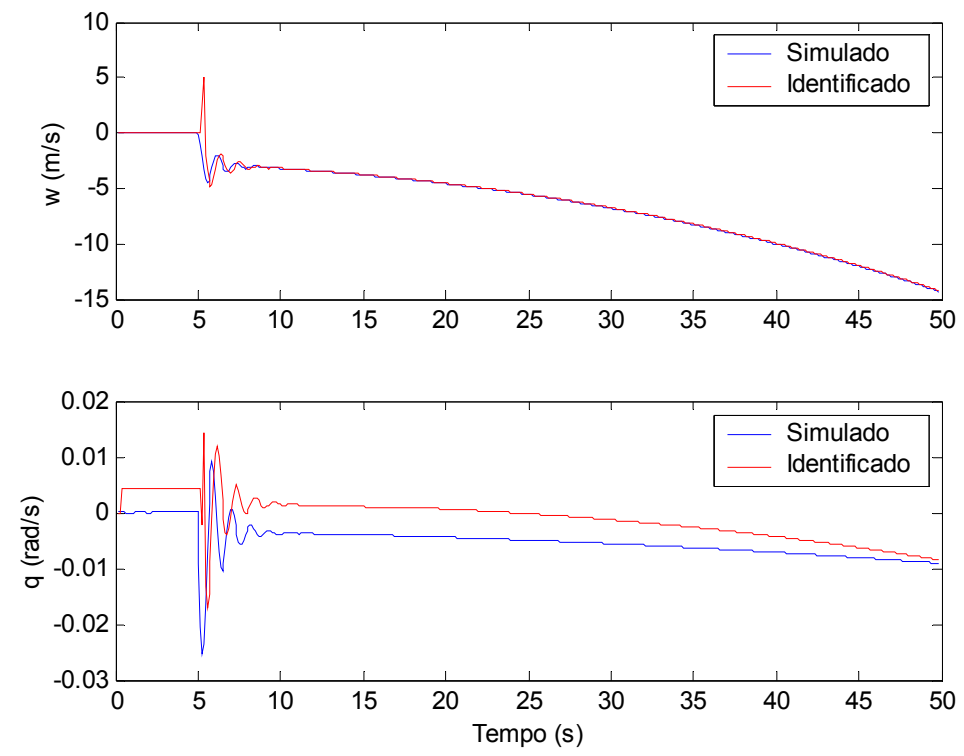

Figura 4.29. Respostas de $w(t)$ e $q(t)$ apresentadas na Figura 4.28 até 50 segundos. 


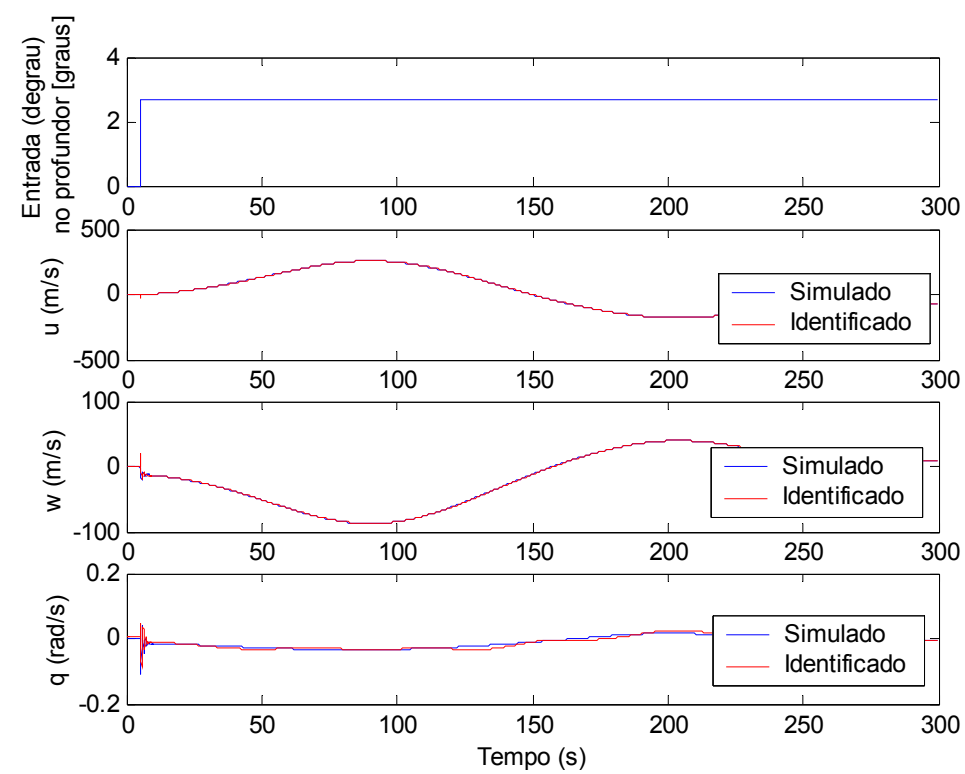

Figura 4.30 Resultado gerado pela RNA referente ao Caso 9 com entrada degrau de $2,2^{\circ}$ no profundor.
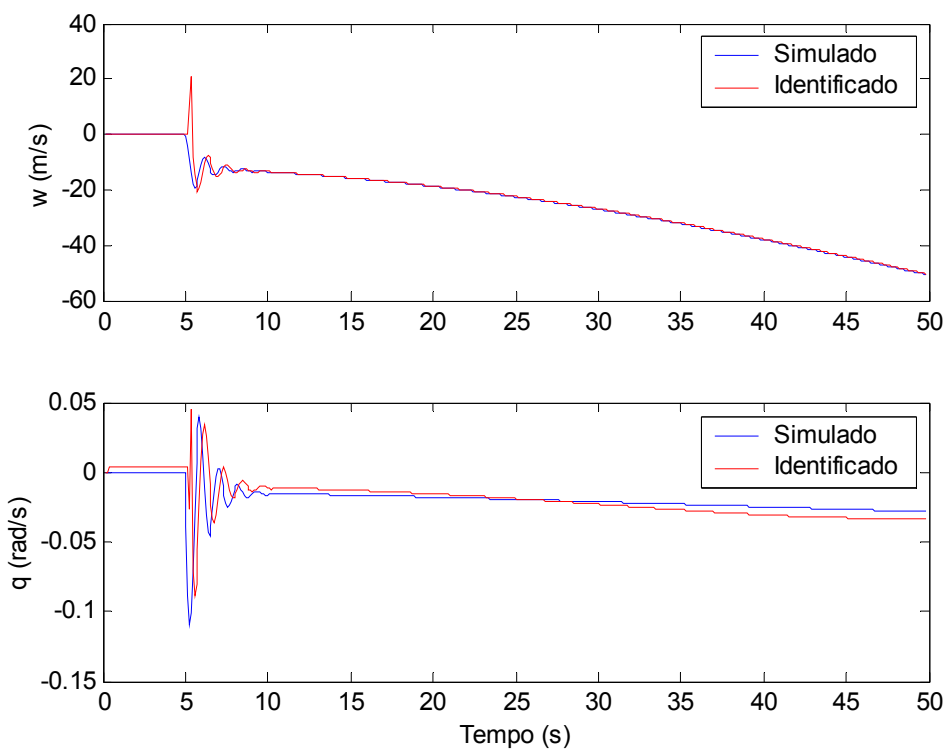

Figura 4.31. Respostas de $w(t)$ e $q(t)$ apresentadas na Figura 4.30 até 50 segundos. 


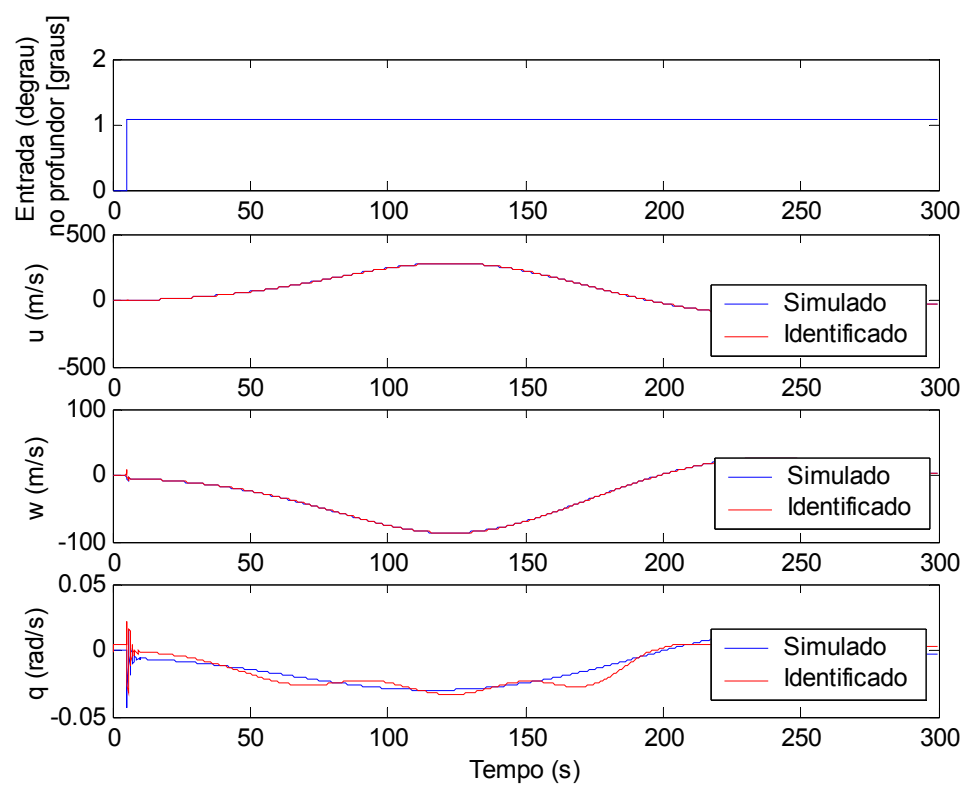

Figura 4.32 Resultado gerado pela RNA referente ao Caso 9 com entrada degrau de $1,1^{\circ}$ no profundor.
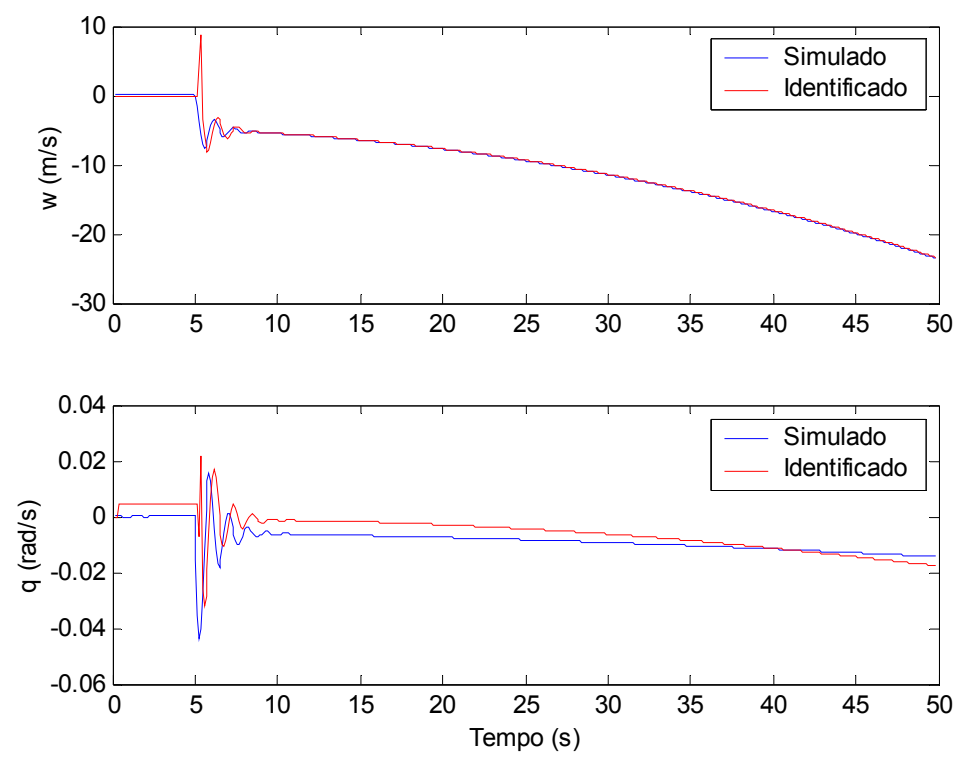

Figura 4.33. Respostas de $w(t)$ e $q(t)$ apresentadas na Figura 4.32 até 50 segundos.

Como foi dito anteriormente, estes testes foram realizados usando dados de casos do envelope de vôo conhecidos pela RNA, porém usando entradas nos profundores diferentes das usadas em treinamento e com maiores ângulos. Portanto, estes resultados são também considerados válidos. 


\subsection{Resultados da generalização para pontos do envelope de vôo desconhecidos pela RNA}

Os resultados apresentados nesta seção se referem à identificação dos estados da aeronave em pontos do envelope de vôo que não foram usados durante o treinamento da RNA. Como mostrado, no Caso 1 a aeronave está voando a uma altitude 10.800 metros e Mach 0,4. Serão apresentados resultados de alguns testes realizados, todos com simulações de entradas diferentes no profundor. O primeiro deles está apresentado na Figura 4.34, onde foi aplicada uma entrada degrau também de 1,6 graus no profundor.

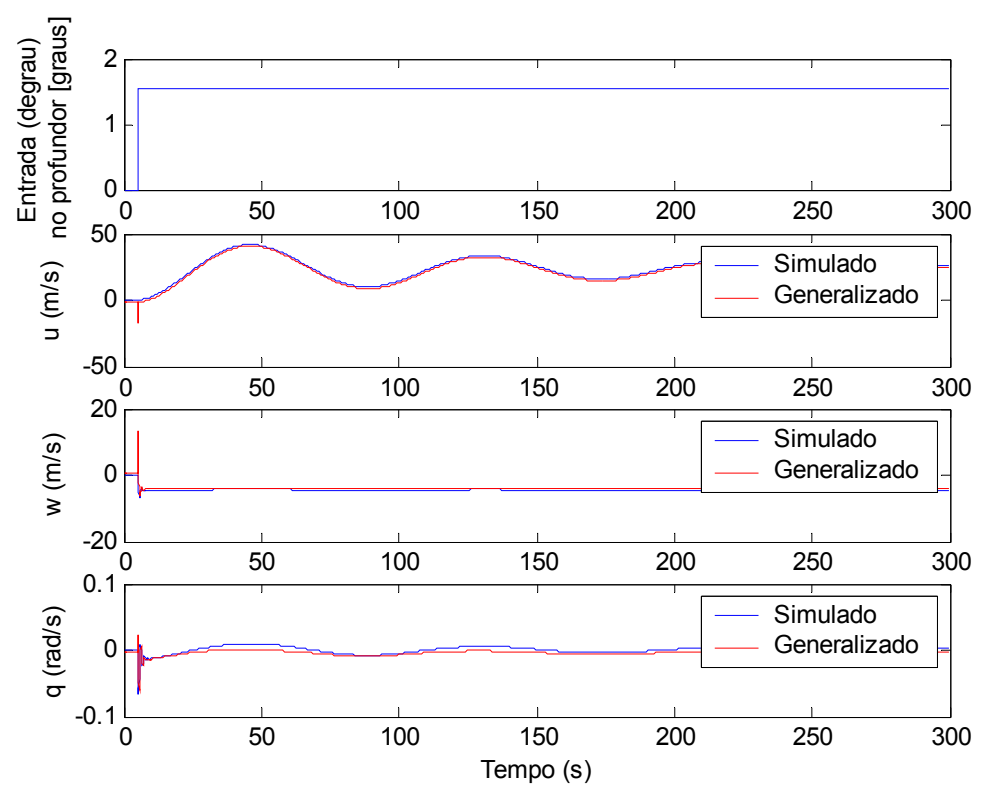

Figura 4.34. Identificação das respostas da aeronave no Caso 1 do envelope de vôo após aplicação de degrau de 1,6 no profundor.

Para facilitar a visualização dos resultados de $w$ e $q$ da Figura 4.34 mostrada anteriormente, foi plotada a Figura 4.35 onde são mostradas as respostas somente até 50 segundos. 

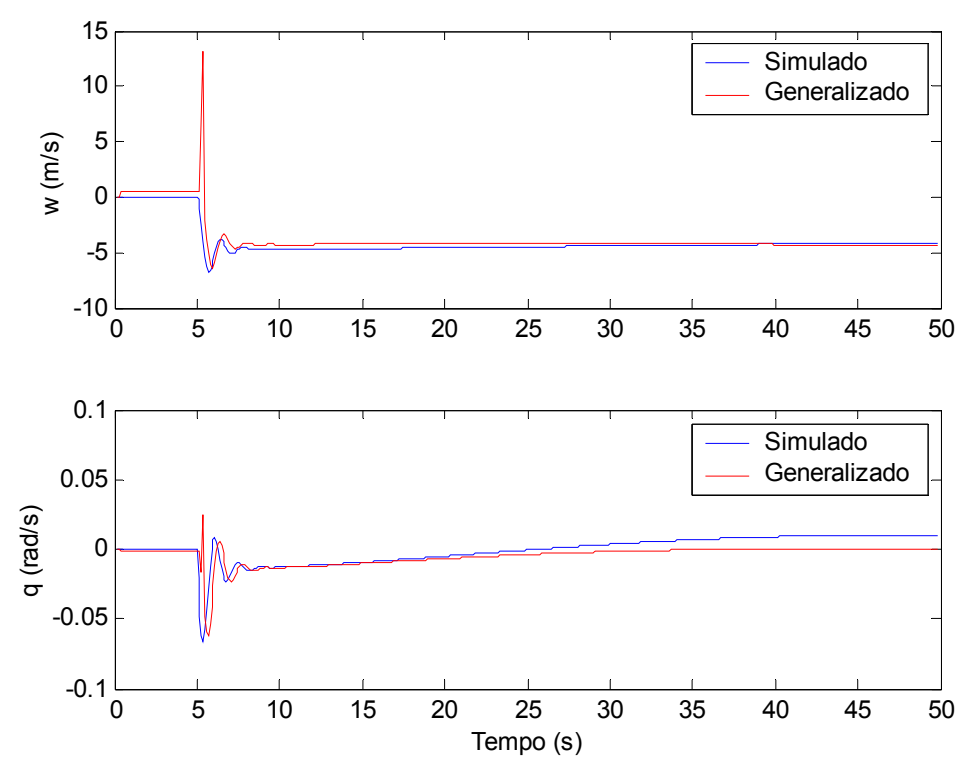

Figura 4.35. Respostas de $w(t)$ e $q(t)$ apresentadas na Figura 4.34 até 50 segundos.

O segundo teste realizado para verificar se a rede havia capturado a dinâmica da aeronave para o Caso 1 está apresentado na Figura 4.35. Foi aplicada uma entrada rampa num intervalo de 2 segundos, indo até 3,8 graus juntamente com um ruído, ou seja, um sinal aleatório com frequências indo até $0,01 \pi / 180 \mathrm{rad} / \mathrm{s}$. Esta escala do sinal foi obtida empiricamente comparando-se com sinais reais de ensaio em vôo A rede identificou satisfatoriamente as respostas da aeronave, exceto $q$ como se pode observar. A Figura 4.37 mostra detalhes das respostas mostradas na Figura 4.36.

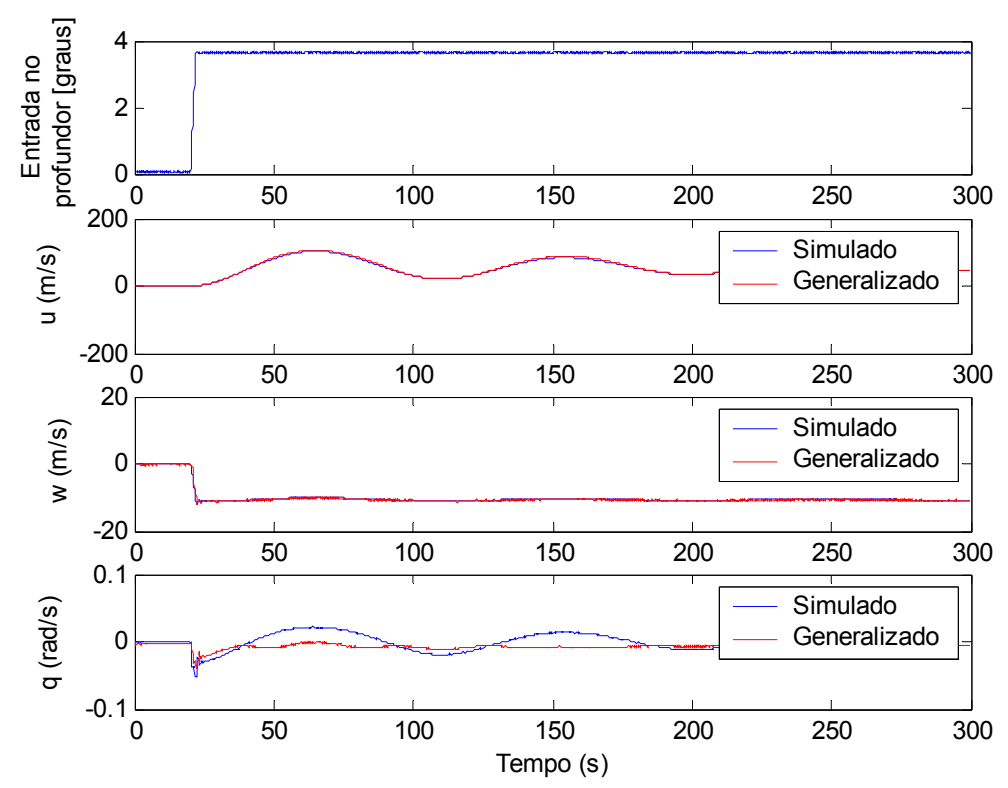

Figura 4.36. Identificação das respostas da aeronave no ponto 1 do envelope de vôo após aplicação de sinal rampa juntamente com ruído no profundor. 


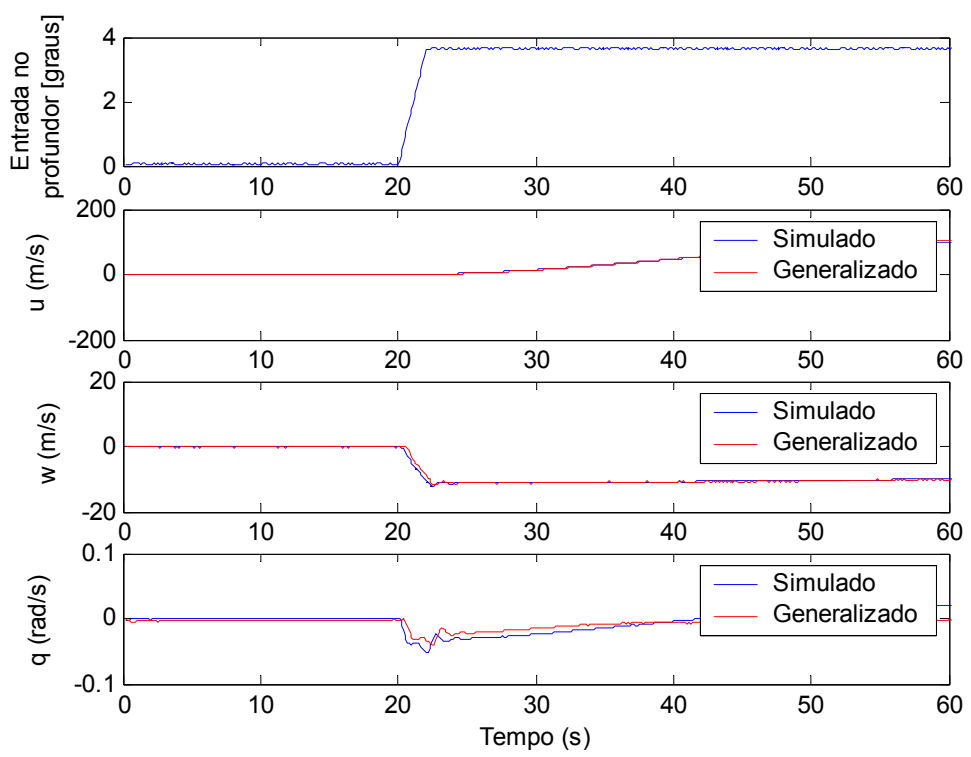

Figura 4.37. Detalhes da entrada rampa, velocidade horizontal, velocidade vertical e velocidade de arfagem.

Novamente não se constata a presença de picos nas respostas apresentadas nas Figuras 4.36 e 4.37 , confirmando que a presença de transientes quando usado o sinal degrau como entrada é numérico.

Também para o Caso 1 do envelope um terceiro teste foi realizado. Foi aplicado um sinal senoidal no profundor e simulado o modelo. $O$ resultado da identificação foi também bastante satisfatório como se pode observar na Figura 4.38. 


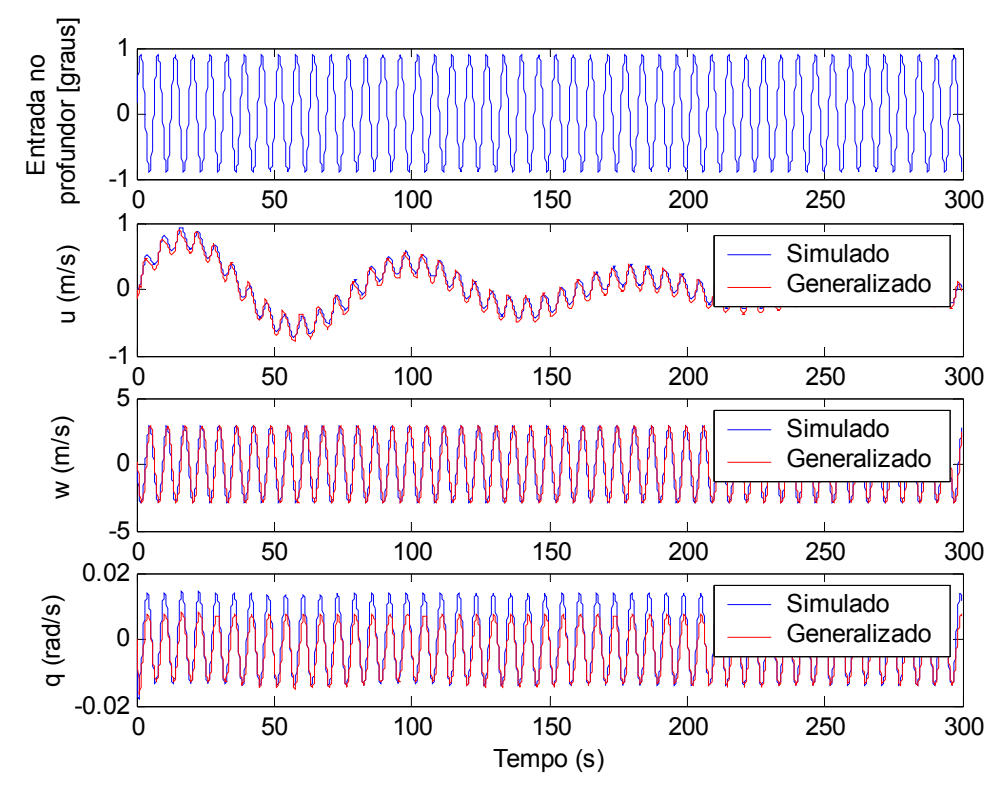

Figura 4.38. Identificação das respostas da aeronave no ponto 1 do envelope de vôo após aplicação de sinal senoidal no profundor.

Existem algumas manobras consagradas para ensaios em vôo visando identificação dos parâmetros aerodinâmicos de uma aeronave, como por exemplo, o Doublet, 2-1-1, 3-2-1-1 e 3-2-1-1 modificado. O princípio para o estabelecimento do formato dessas manobras e a especificação das amplitudes e tempos dos pulsos é a análise do conteúdo espectral do sinal através do PSD (Power Spectral Density) ou Densidade Espectral de Potência. O caso da manobra 3-2-1-1, o nome se deve ao seu formato que é dado por um pulso positivo de três unidades de tempo $(3 \Delta t)$, um pulso no sentido contrário de duas unidades de tempo $(2 \Delta t)$, outro pulso positivo de uma unidade de tempo $(\Delta t)$ e outro pulso contrário de uma unidade de tempo $(\Delta t)$. A determinação do valor de $t$ é feita de modo a deslocar o maior conteúdo de potencia para a freqüência natural que se deseja excitar.

Também para o Caso 1 a aeronave foi simulada sofrendo uma entrada "trem de pulsos" e entrada chamada de 3-2-1-1 no profundor e a rede também identificou satisfatoriamente suas respostas, como mostram as Figuras 4.39 e 4.40. 


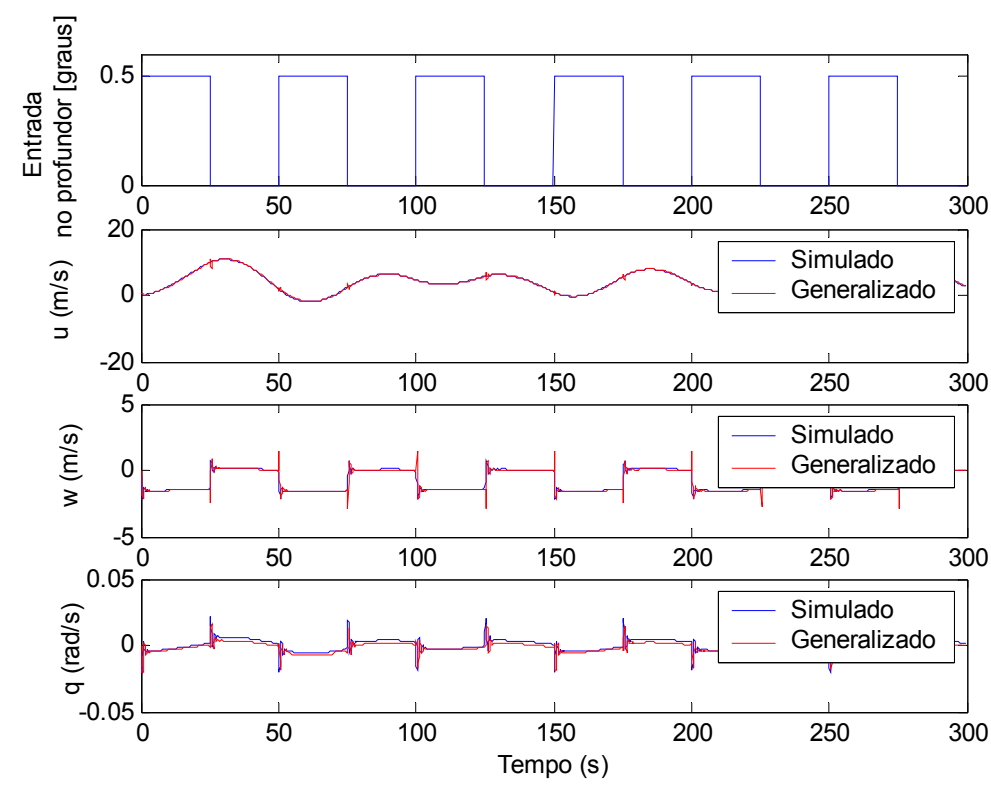

Figura 4.39. Identificação das respostas da aeronave no ponto 1 do envelope de vôo após aplicação de trem de pulsos no profundor.

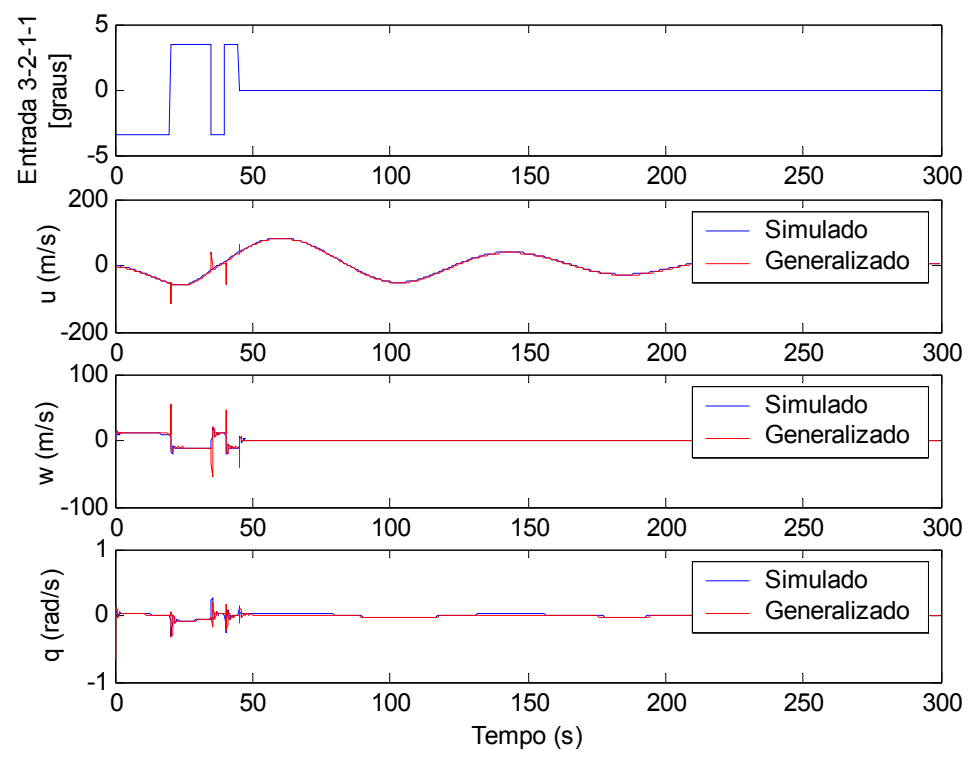

Figura 4.40. Identificação das respostas da aeronave no ponto 1 do envelope de vôo após aplicação de entrada 3-2-1-1 no profundor.

A entrada 3-2-1-1 é bastante usada em ensaios em vôo quando o objetivo é conseguir dados para identificação de parâmetros, pois excita modos com várias frequências. 

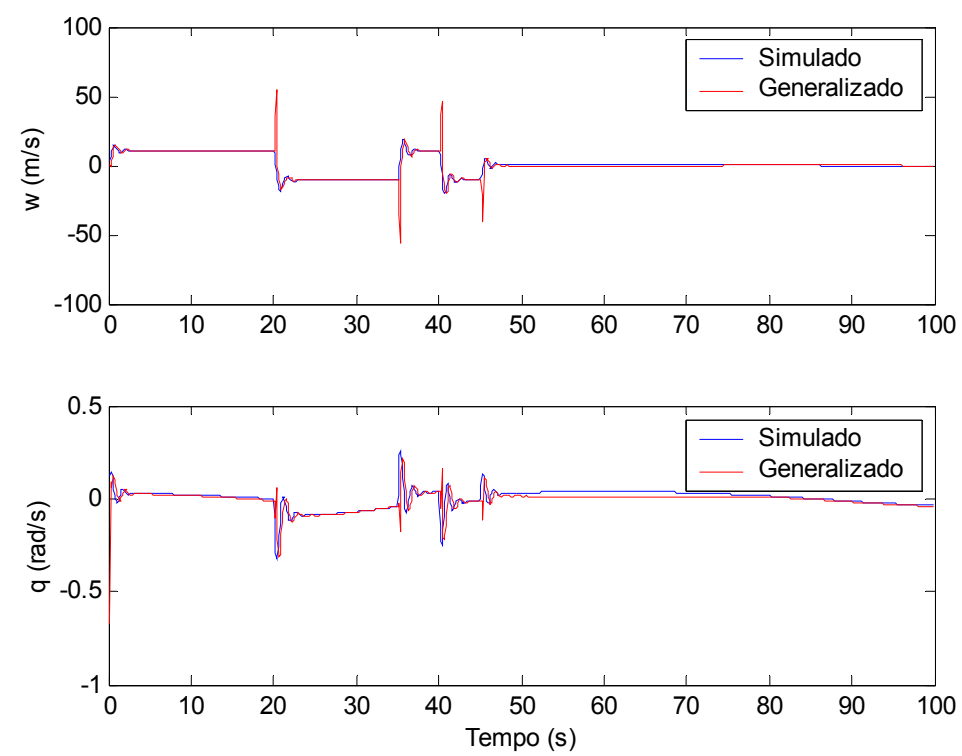

Figura 4.41. Variações em $w(t)$ e $q(t)$ para o tempo de até 100 segundos.

Para todos os casos do envelope, foram feitos vários outros testes com diferentes sinais de entrada nos profundores, mas não serão apresentados para não deixar o texto extenso. Destaca-se que todos os testes apresentaram resultados bastante satisfatórios

A seguir estão apresentados alguns resultados da identificação das respostas da aeronave no ponto 2 do envelope. Como se pôde observar na Figura 4.9, a altitude correspondente ao Caso 2 é $4572 \mathrm{~m}$ e Mach 0,4. O resultado do primeiro teste de identificação realizado está apresentado na Figura 4.42 a seguir. Para conseguir dados para este teste, foi aplicada uma entrada no profundor de 0,4 graus, no tempo de 5 segundos. O resultado da identificação de $u, w$ e $q$ foram bastante satisfatórios. 


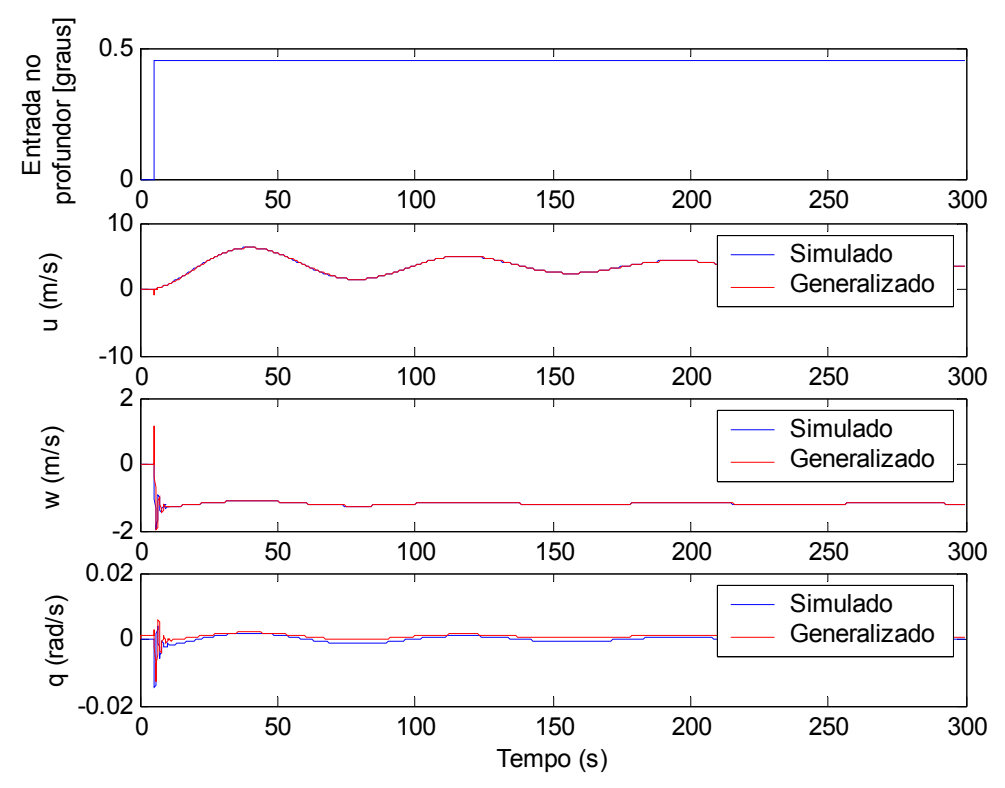

Figura 4.42. Identificação das respostas da aeronave no ponto 2 do envelope de vôo após aplicação de entrada degrau no profundor.

A Figura 4.43 mostra detalhadamente os resultados de $w$ e $q$, até o tempo de 50 segundos, pois é até aproximadamente este tempo que ocorrem as maiores variações.
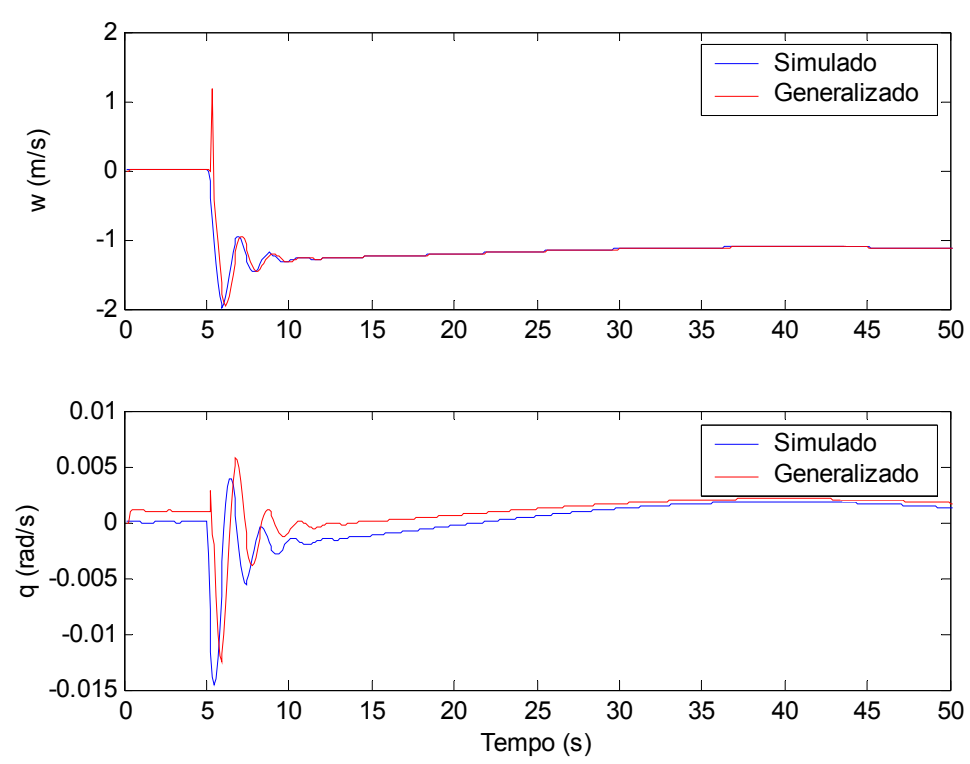

Figura 4.43. Respostas de velocidade vertical e de arfagem da aeronave para o tempo de até 50 segundos.

Na Figura 4.44 estão mostrados os resultados de identificação também para a simulação da aeronave voando nas condições correspondentes ao ponto 2 do envelope, porém dando entrada 
trem de pulsos com período de 50 segundos nos profundores e amplitude de 1 grau. Os resultados obtidos também foram satisfatórios.

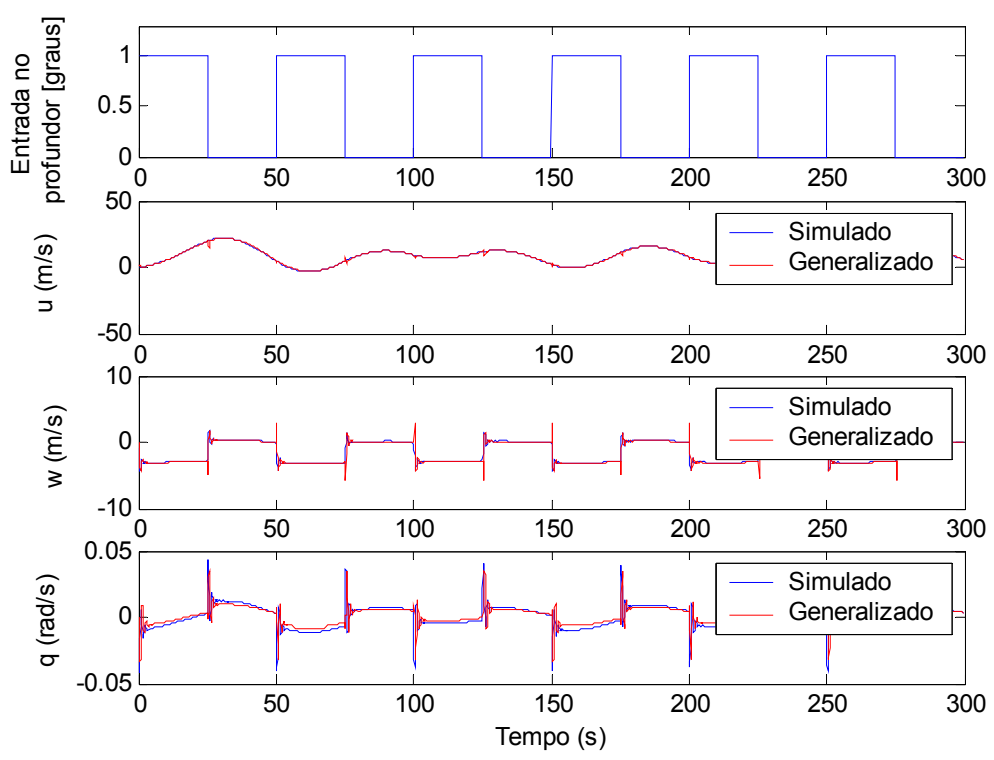

Figura 4.44. Identificação das respostas da aeronave voando em condições correspondentes ao ponto 2 do envelope de vôo após aplicação de trem de pulsos no profundor.

Também para a condição de vôo correspondente ao caso 2, foi realizado um terceiro teste, agora usando como entrada um sinal senoidal com freqüência de $1 \mathrm{rad} / \mathrm{s}$ no profundor. $\mathrm{O}$ resultado da identificação está mostrado na Figura 4.45.

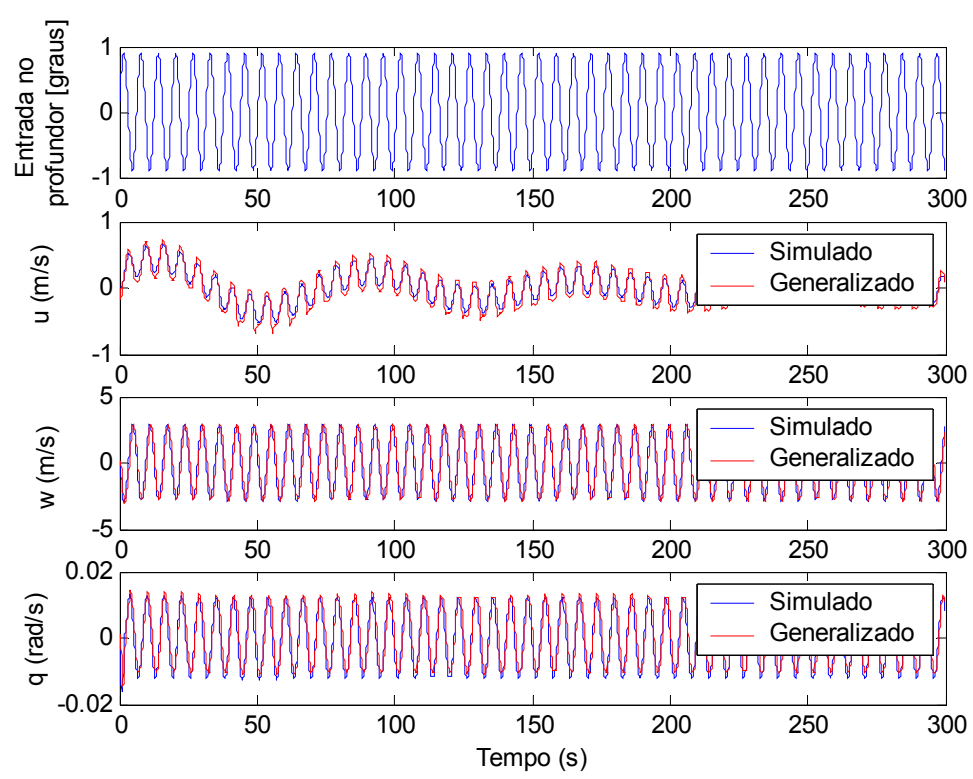

Figura 4.45. Identificação das respostas da aeronave no ponto 2 do envelope de vôo após aplicação de entrada senoidal no profundor. 
A Figura 4.46 apresenta o resultado de um novo teste realizado usando entrada 3-2-1-1 nos profundores também para o Caso 2. Os resultados obtidos foram bastante satisfatórios.
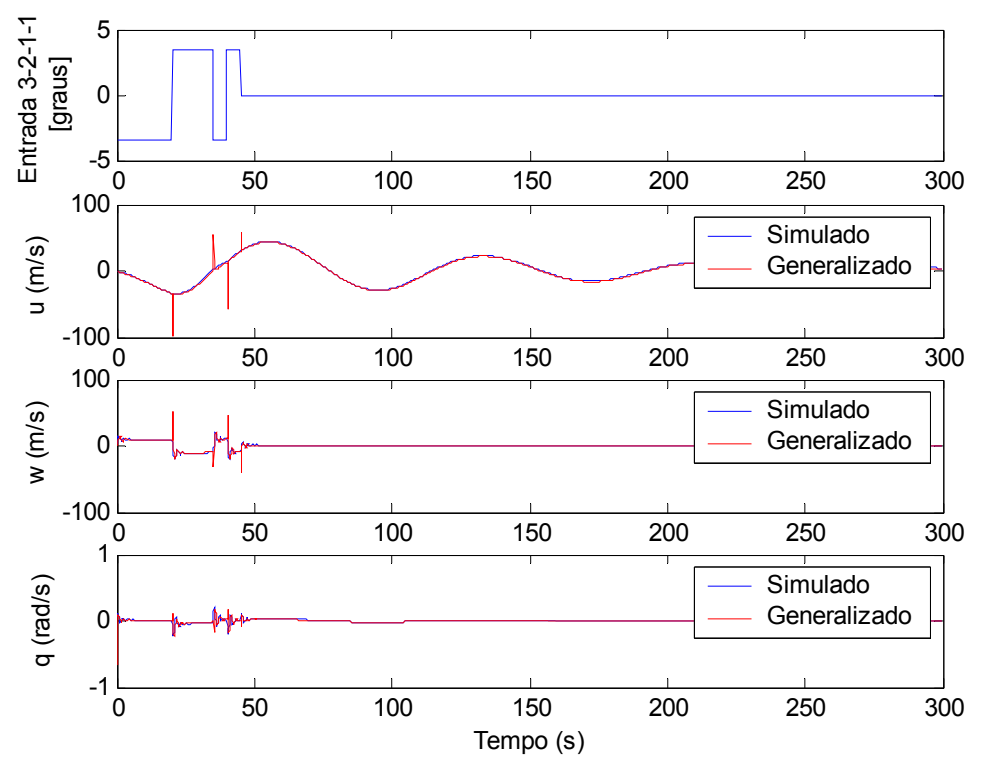

Figura 4.46. Identificação das respostas da aeronave no ponto 2 do envelope de vôo após aplicação de entrada 3-2-1-1 no profundor.
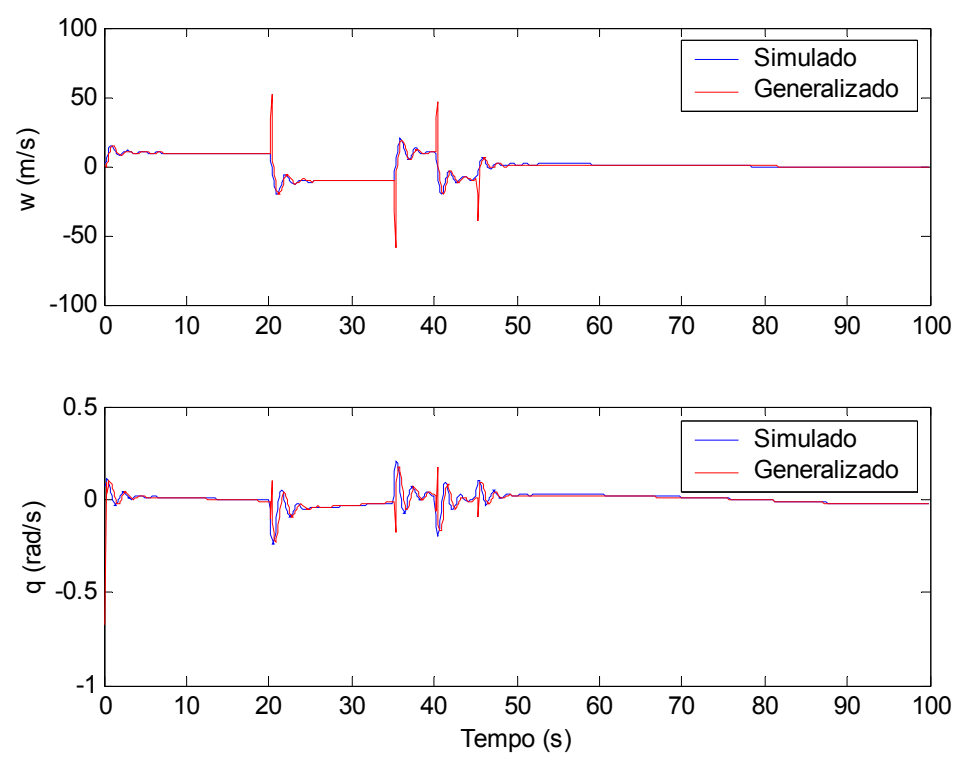

Figura 4.47. Variações em $w$ e $q$ para o tempo de até 100 segundos.

A seguir estão apresentados os resultados da identificação das respostas da aeronave voando em condições apresentadas no ponto 3 do envelope de vôo. No caso 3 a aeronave estava 
com velocidade correspondente a Mach 0,6 e altitude de 4572 metros. A Figura 4.48 apresenta os resultados da identificação usando como entrada no profundor um degrau de 1,2 graus.

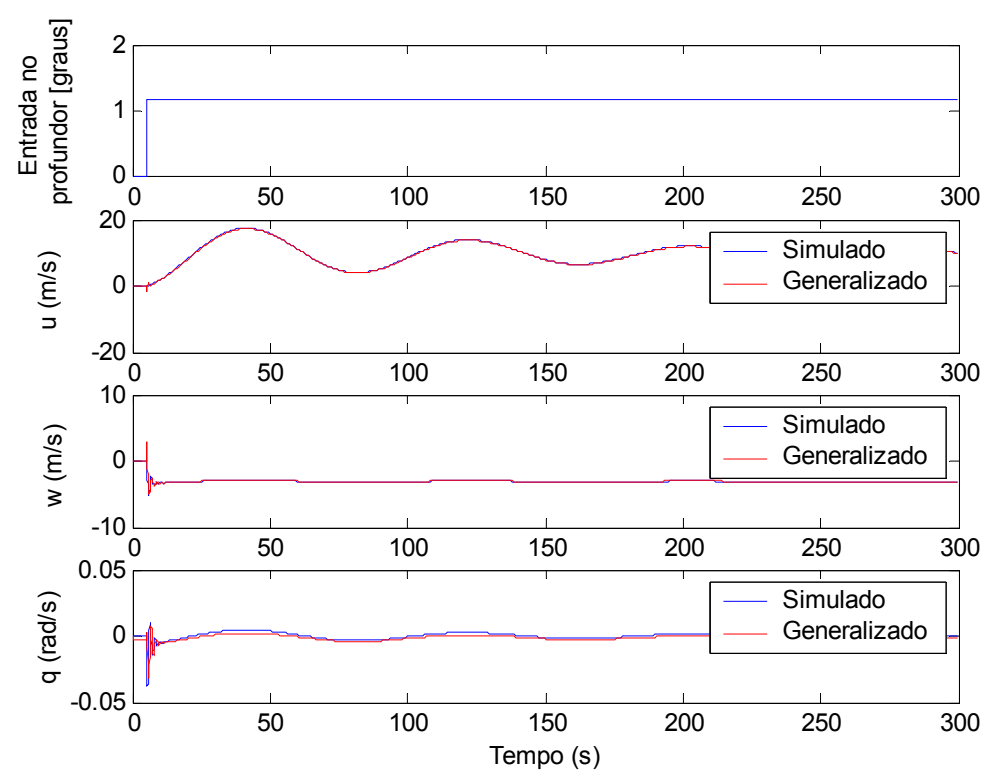

Figura 4.48. Identificação das respostas da aeronave no ponto 3 do envelope de vôo após aplicação de entrada degrau no profundor.

Na Figura 4.49 estão mostradas as variações ocorridas em $w$ e $q$ até 50 segundos apenas.
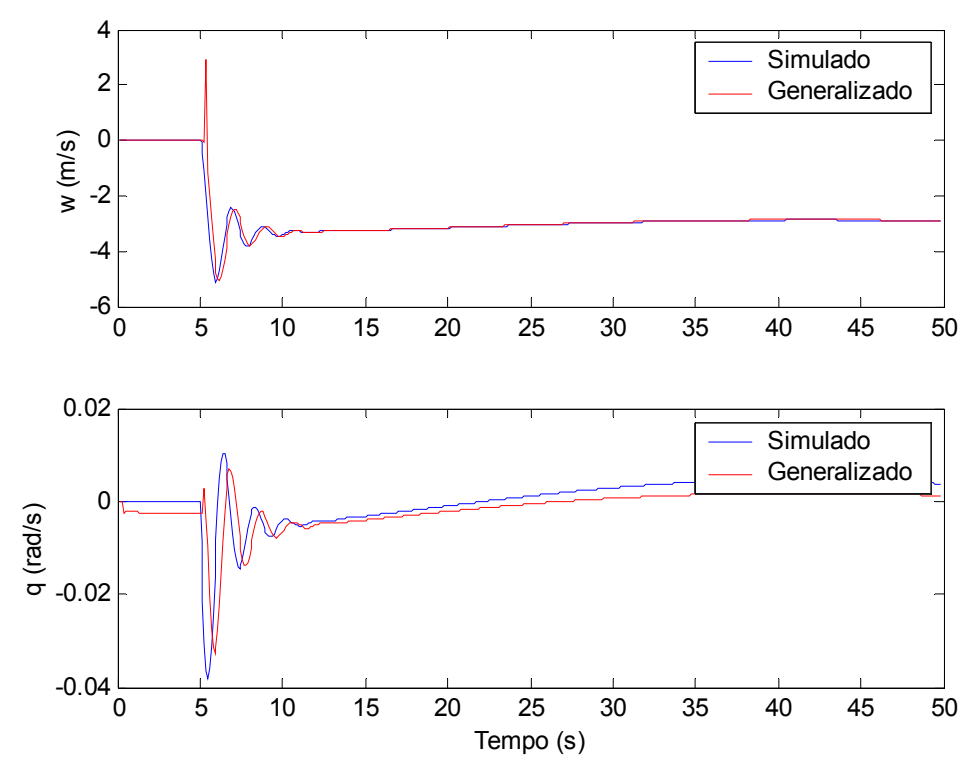

Figura 4.49. Variações de $w(t)$ e $q(t)$ até 50 segundos. 
A Figura 4.50 mostra a identificação usando como entrada um sinal trem de pulsos com período de 50 segundos e amplitude de 0,5 grau.

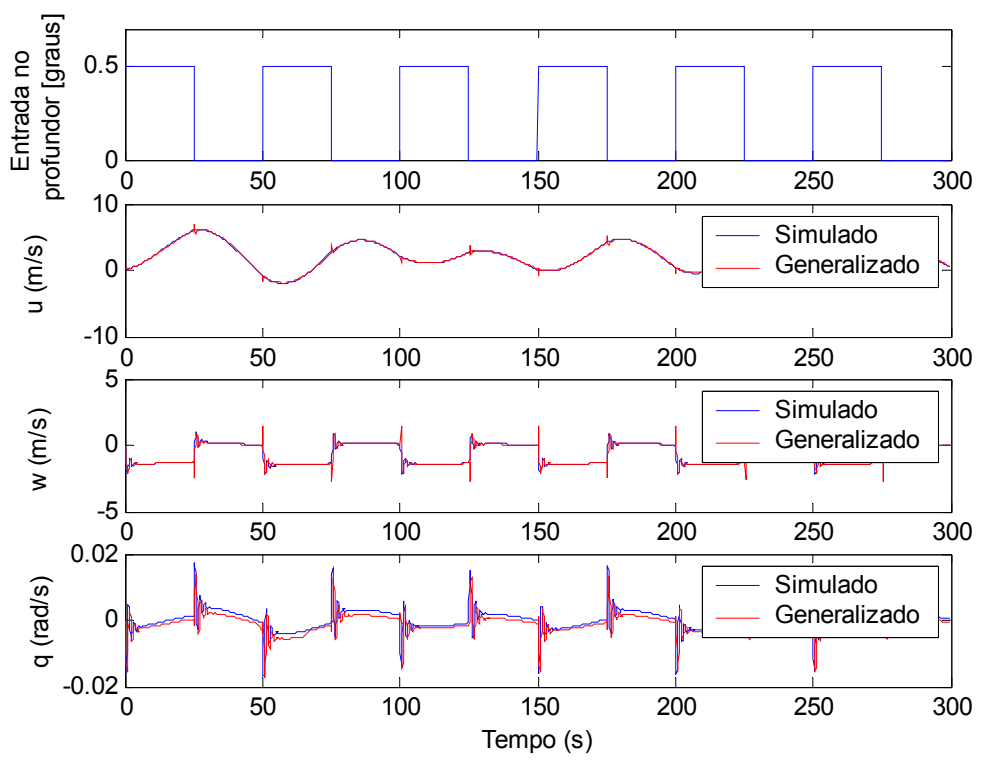

Figura 4.50. Identificação das respostas da aeronave no ponto 3 do envelope de vôo após aplicação de entrada trem de pulsos no profundor.

Na Figura 4.51 a seguir está apresentado o resultado da identificação das respostas da aeronave também para o caso 3, porém usando como entrada no profundor um sinal 3-2-1-1.

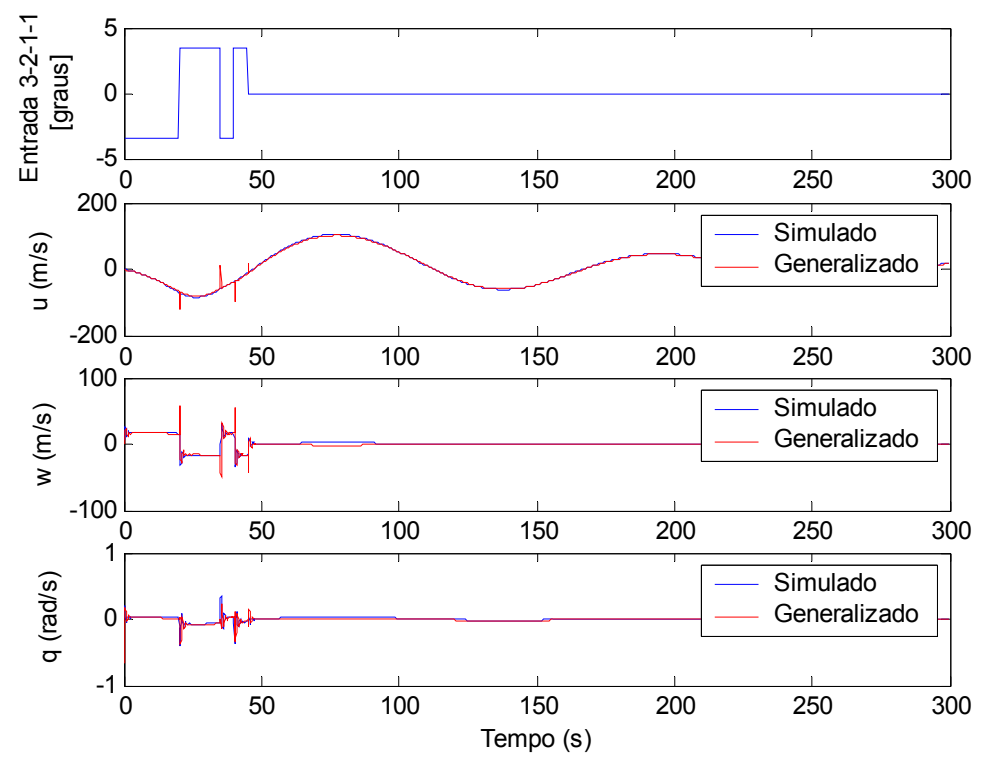

Figura 4.51. Identificação das respostas da aeronave no ponto 3 do envelope de vôo após aplicação de entrada 3-2-1-1 nos profundores. 

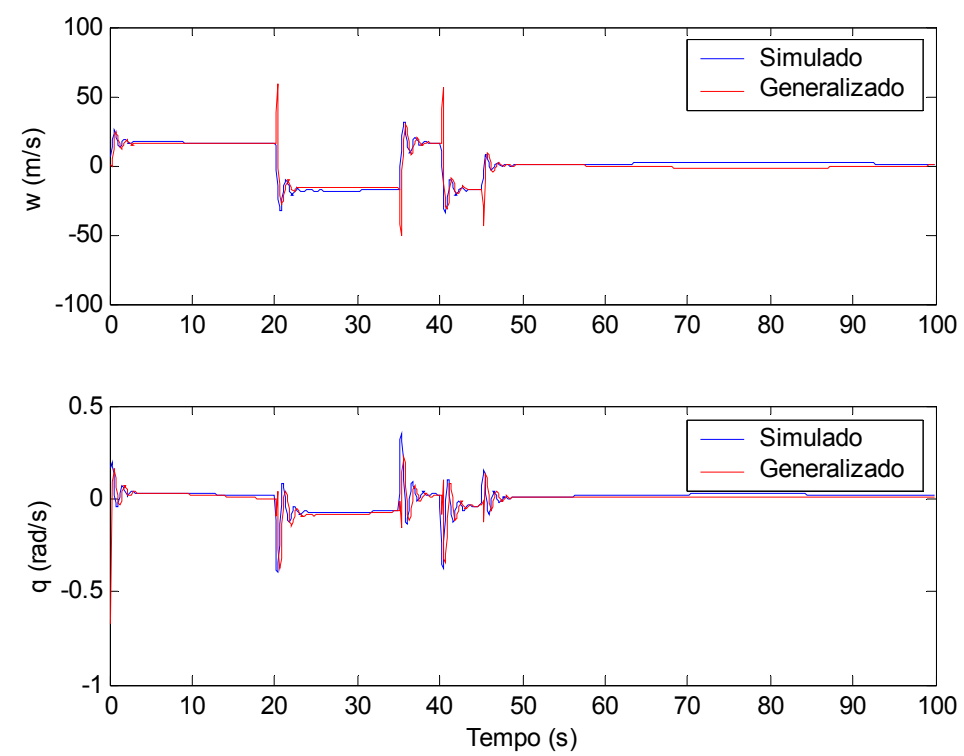

Figura 4.52. Variações em $w(t)$ e $q(t)$ para o tempo de até 100 segundos.

Serão apresentados agora os resultados da identificação do ponto 7 do envelope de vôo. Como mostrado no esquema do envelope de vôo, a aeronave neste ponto está a 4572 metros de altitude, em vôo trimado e Mach 0,4. Para a realização do primeiro teste, o modelo foi simulado sofrendo uma entrada degrau de 2,2 graus no profundor e o resultado está apresentado na Figura 4.53 a seguir.

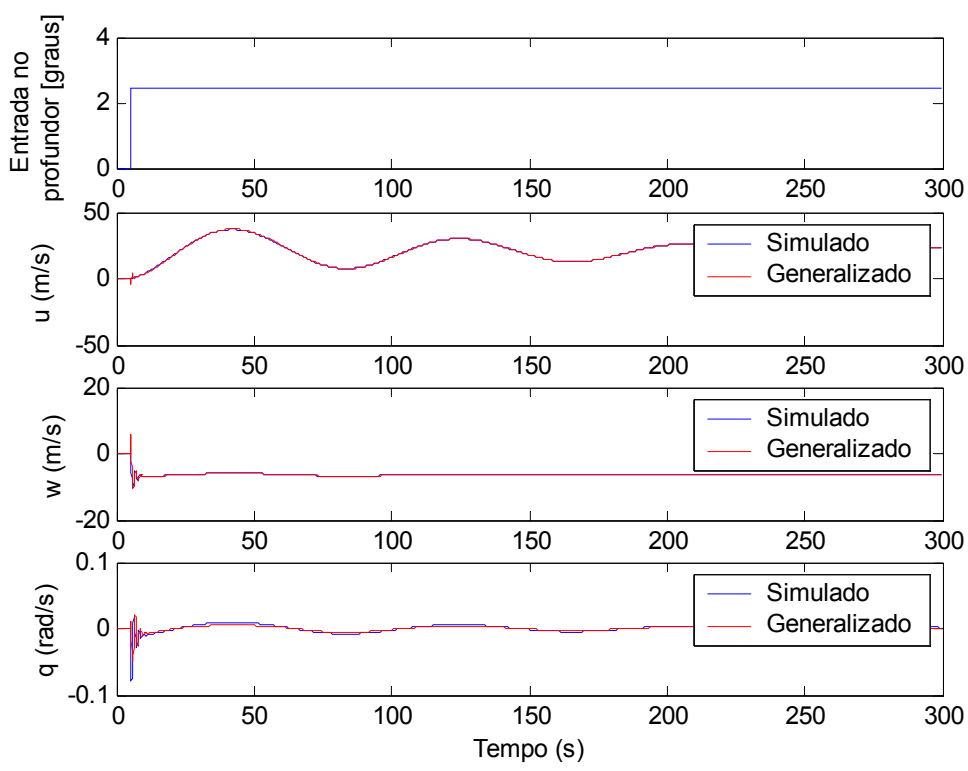

Figura 4.53. Identificação das respostas da aeronave no ponto 7 do envelope de vôo após aplicação de entrada degrau nos profundores. 
Outros testes foram realizados. A Figura 4.54 mostra resultados da identificação após aplicação de trem de pulsos nos profundores, com período de 50 segundos e amplitude de 0,5 graus e a Figura 4.55 apresenta os resultados da identificação, também para o ponto 7 do envelope, usando entrada do tipo senoidal nos profundores, com freqüência de $1 \mathrm{rad} / \mathrm{s}$ e amplitude de 0,5 graus.

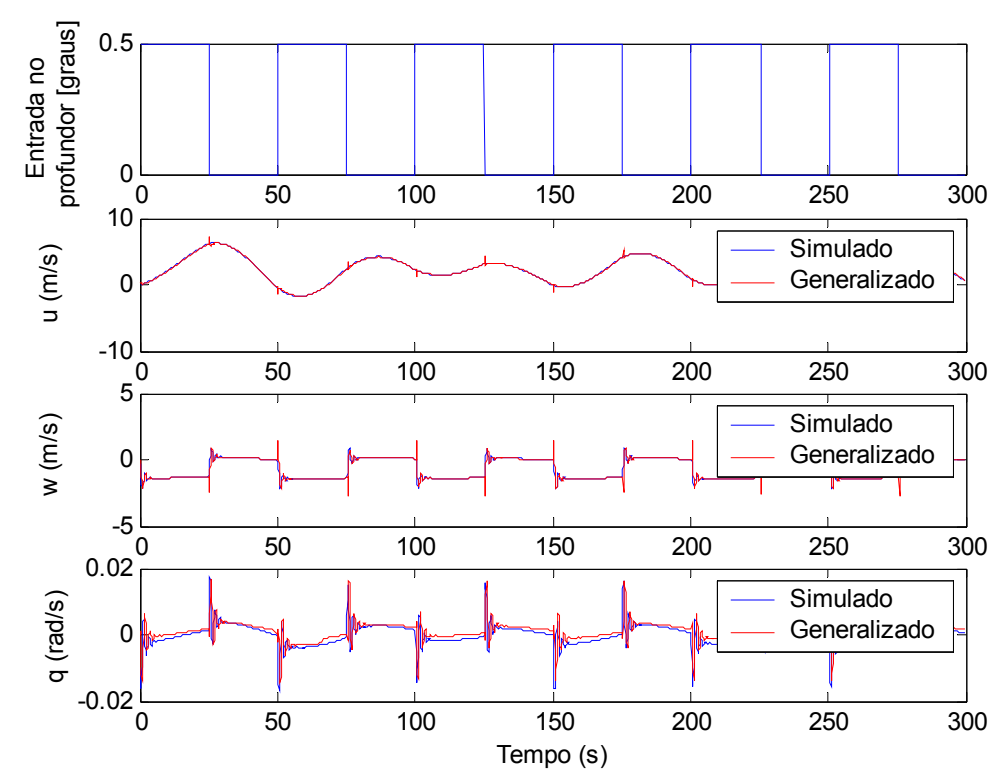

Figura 4.54. Identificação das respostas da aeronave no ponto 7 do envelope de vôo após aplicação de entrada trem de pulsos nos profundores.
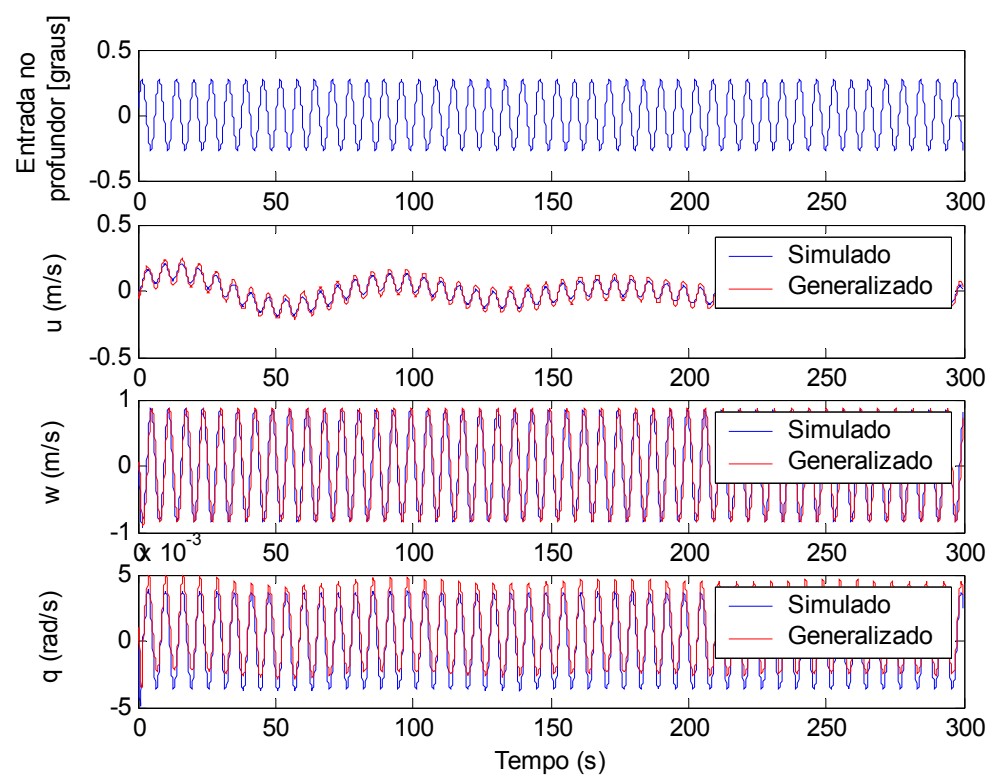

Figura 4.55. Identificação das respostas da aeronave no ponto 7 do envelope de vôo após aplicação de entrada do tipo senoidal nos profundores. 
Na Figura 4.56 estão apresentados os resultados da identificação das respostas da aeronave, também para o ponto 7 do envelope, após ter sofrido entrada do tipo 3-2-1-1 nos profundores.

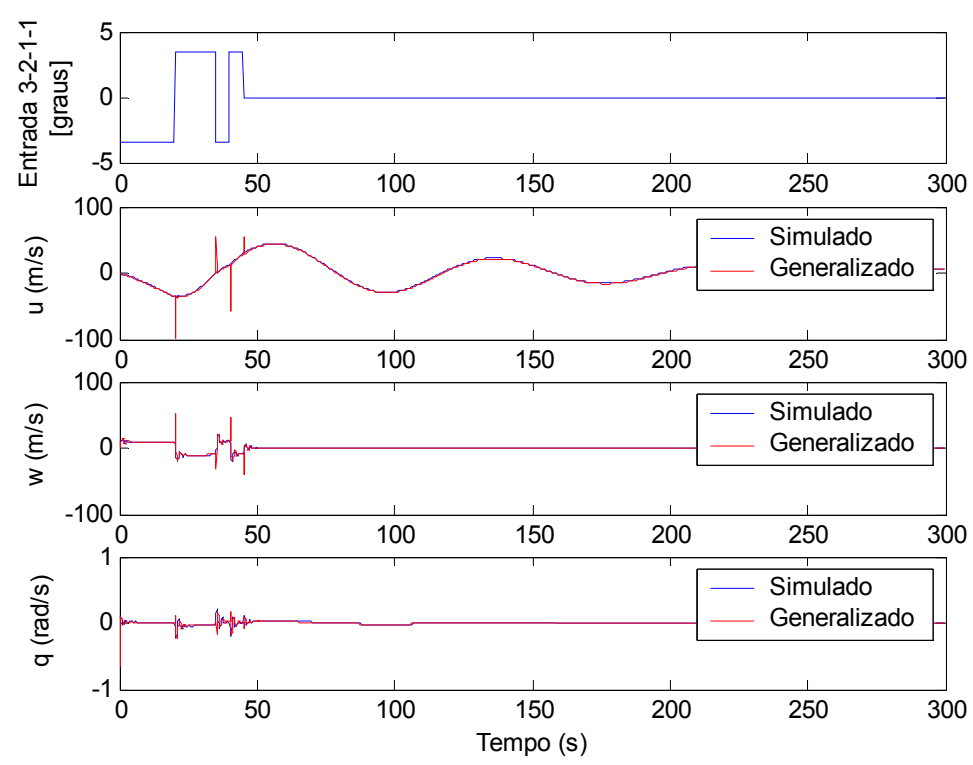

Figura 4.56. Identificação das respostas da aeronave no ponto 7 do envelope de vôo após aplicação de entrada 3-2-1-1 nos profundores.

Análogo ao feito anteriormente, para melhor visualização das variações em $w(t)$ e $q(t)$, a Figura 4.57 mostra as respostas até o tempo de 100 segundos apenas.
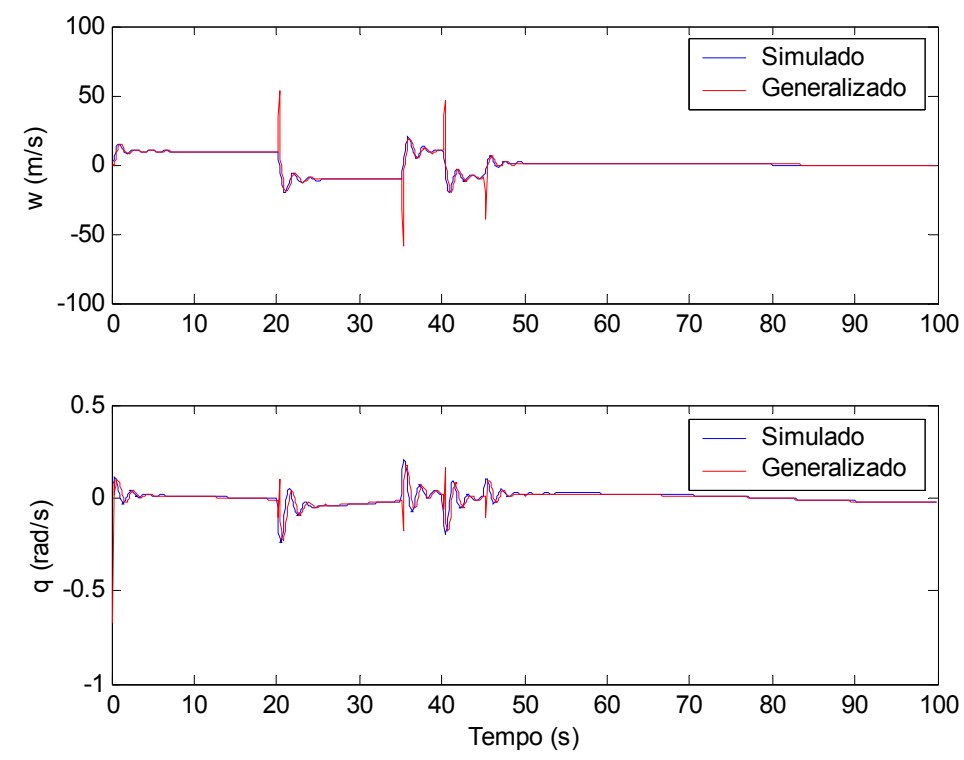

Figura 4.57. Variações em $w(t)$ e $q(t)$ para o tempo de até 100 segundos. 
Finalmente serão apresentados os resultados de alguns testes realizados com o modelo neural para dados da aeronave voando nas condições apresentadas no Caso 4 do envelope de vôo.

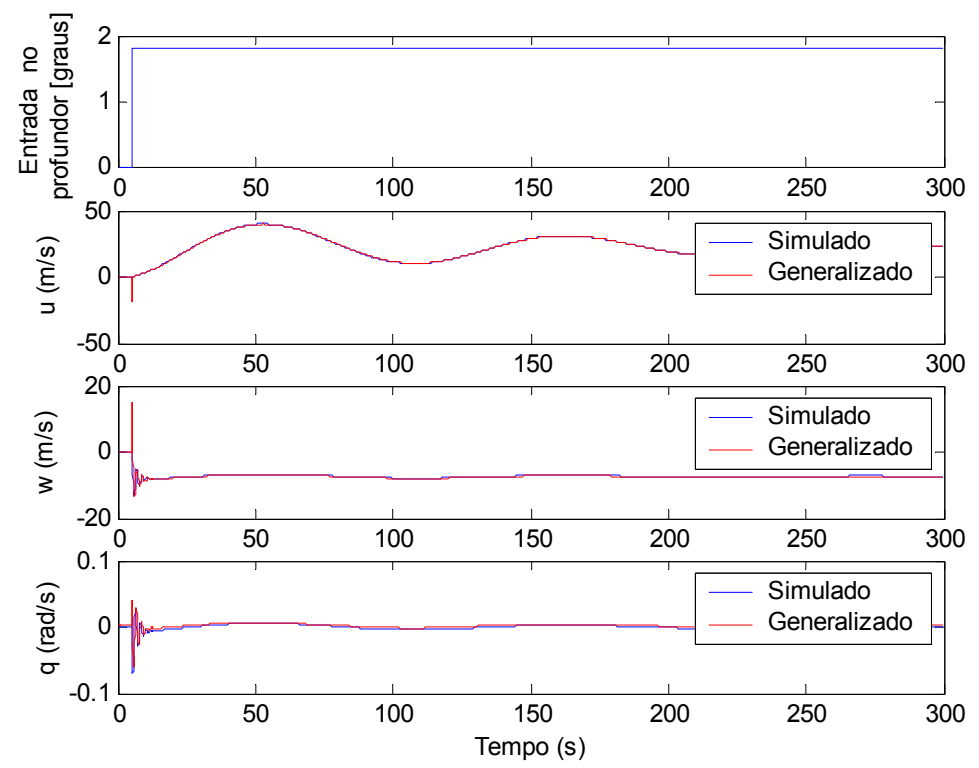

Figura 4.58. Identificação das respostas da aeronave no ponto 4 do envelope de vôo após aplicação de entrada degrau de $1,8^{\circ}$ nos profundores.

Os resultados obtidos foram bastante satisfatórios também como pode-se observar.
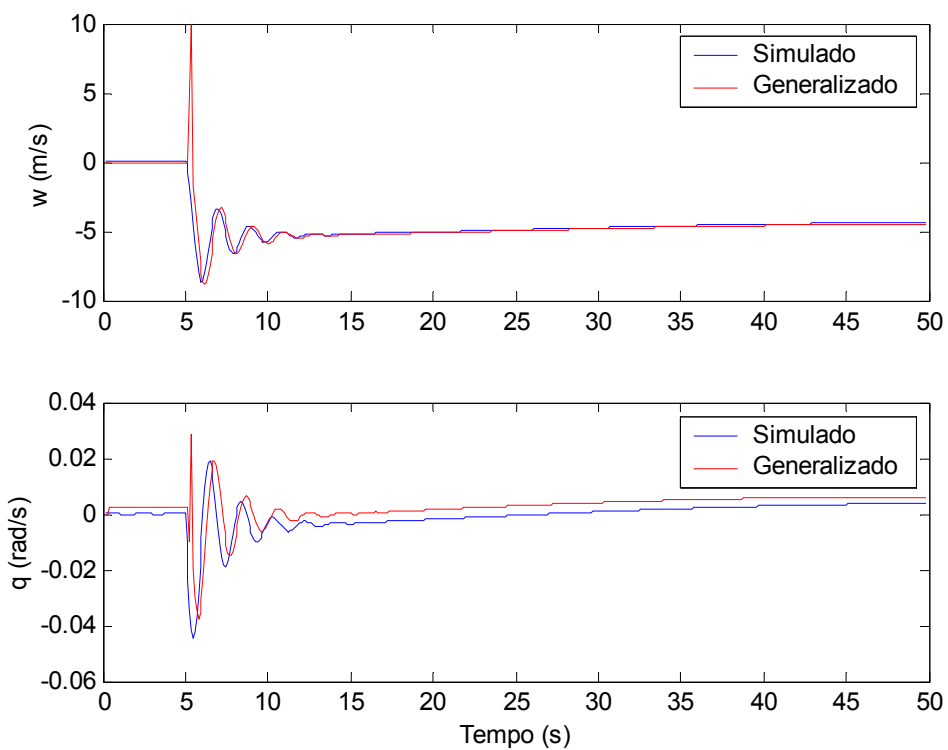

Figura 4.59. Detalhes das variações em $w(t)$ e $q(t)$ para o tempo de até 50 segundos. 
Um segundo teste será apresentado para o mesmo caso, porém usando entrada 3-2-2-1 nos profundores.

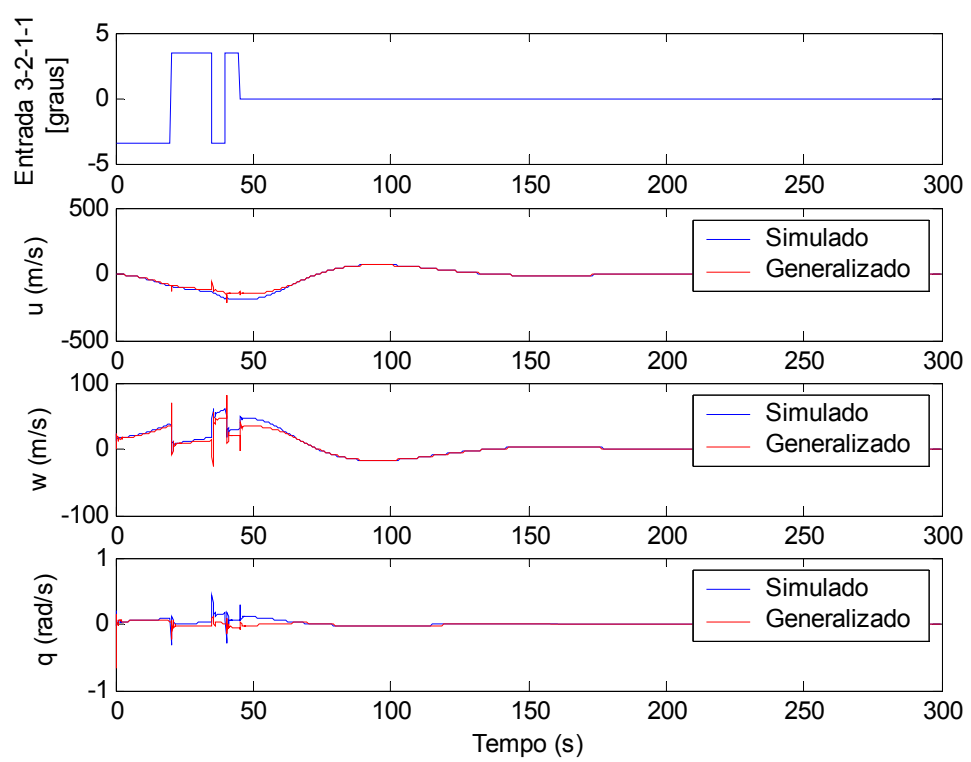

Figura 4.60. Identificação das respostas da aeronave no ponto 4 do envelope de vôo após aplicação de entrada 3-2-2-1 nos profundores.

Um terceiro teste será apresentado para o mesmo caso 4, porém usando entrada trem de pulsos nos profundores.

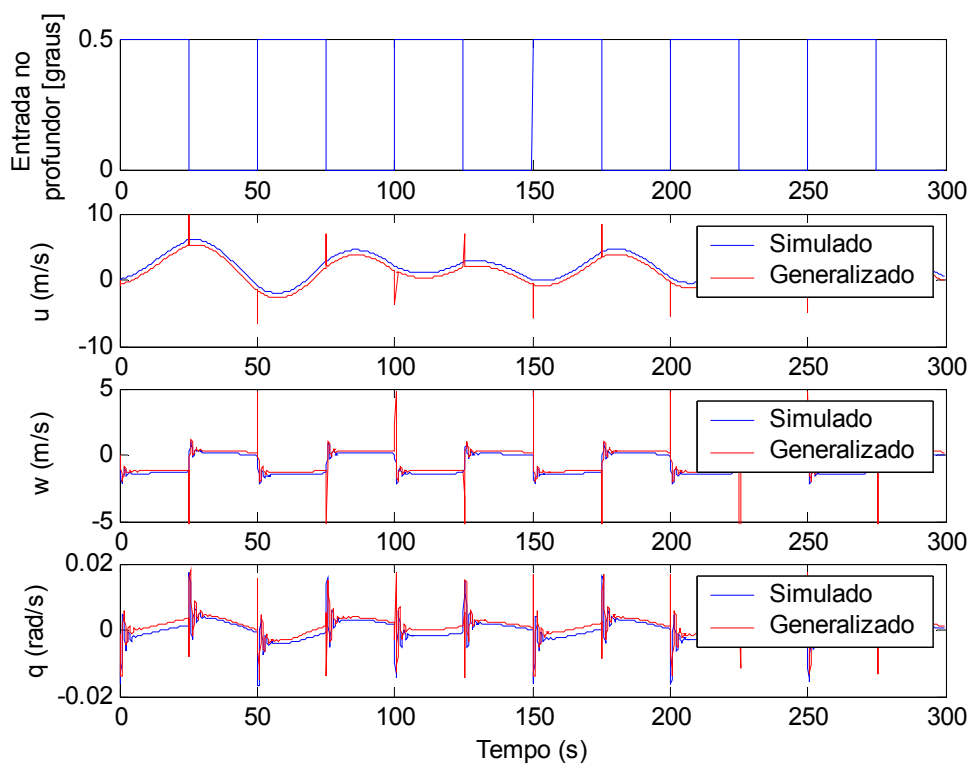

Figura 4.61. Identificação das respostas da aeronave no ponto 4 do envelope de vôo após aplicação de trem de pulsos no profundor. 


\subsection{Conclusões}

Neste capítulo foram apresentados resultados da simulação do modelo matemático não linear de uma aeronave militar implementado no Simulink ${ }^{\circledR}$ usando dados de 9 condições de vôo retirados da literatura. Foram feitas várias simulações usando dados de casos para treinar a rede, especificamente 3, apenas aplicando sinal degrau nos profundores. Para verificar se a rede estava treinada, foram feitas simulações excitando o modelo com outras entradas como rampa, entrada tipo seno, rampa acrescentando um ruído, trem de pulsos e entrada 3-2-1-1. A rede foi treinada usando o algoritmo Backpropagation com a técnica de otimização de Levenberg-Marquardt, com resultados simulados da aeronave correspondentes aos casos 5, 6, 8 e 9 e apenas dando como entrada um degrau. Depois de treinada a rede, foram feitos vários testes para verificar a identificação dos outros pontos do envelope. Pôde-se verificar que a rede capturou satisfatoriamente a dinâmica da aeronave, identificando com grande sucesso as respostas do movimento longitudinal da aeronave por todo o envelope de vôo considerado, tanto para entrada tipo degrau como para outros tipos de entradas. Porém, observou-se também que a rede neural capturou melhor o modo de movimento de fugóide que o de período curto em quase todos os casos e uma provável causa disto pode ter sido uma falta de treinamento mais apurado. Testes envolvendo estas hipóteses serão realizados e publicados em trabalhos futuros. 


\section{CAPÍTULO 5}

\section{RESULTADOS DA ESTIMAÇÃO DAS DERIVADAS AERODINÂMICAS DE ESTABILIDADE E CONTROLE USANDO REDES NEURAIS ARTIFICIAIS}

\subsection{Introdução}

As derivadas de controle e estabilidade são de extrema importância no estudo da dinâmica de vôo de aeronaves. VASCONCELOS (2002) fala sobre as quatro principais fontes de obtenção das derivadas de controle e estabilidade, citadas a seguir.

- Estimação de parâmetros, como aparece em várias publicações, usando métodos de previsão baseados nas características de projeto da aeronave;

- Aplicação de métodos de dinâmica dos fluidos computacional para a modelagem aerodinâmica da aeronave;

- Obtenção em ensaios realizados em túnel de vento;

- Estimação paramétrica baseada a partir de dados de ensaio em vôo.

Todos estes métodos apresentados acima são bastante eficientes, mas, por exemplo, o método de obtenção de derivadas a partir de dados de ensaio em vôo, apresenta custo financeiro bem mais elevado que os outros. Neste contexto, o objetivo deste Capítulo é mostrar a aplicabilidade de redes neurais com topologias relativamente simples, especificamente, multicamadas feedforward na estimação destas derivadas. Será mostrado que quando são conhecidas as derivadas aerodinâmicas em alguns pontos de um envelope de vôo é possível estimar as derivadas da aeronave em qualquer outro ponto do envelope. Esta metodologia implica numa redução de custo bastante grande na estimação das derivadas. Dois exemplos de aplicação serão apresentados. 
Primeiramente serão mostrados os resultados da metodologia proposta aplicada a um problema simulado e depois a um problema real.

\subsection{Estimação das derivadas aerodinâmicas usando resultados simulados da aeronave A4-D} num envelope de vôo via RNA's

Será apresentada a metodologia para resolução do problema inverso do mostrado no Capítulo 4, isto é, a partir das respostas de velocidades e dados da aeronave, serão estimadas as derivadas de estabilidade desta usando redes neurais feedforward. Um diagrama de blocos representativo do problema completo abordado nesta Tese está mostrado na Figura 5.1 a seguir.

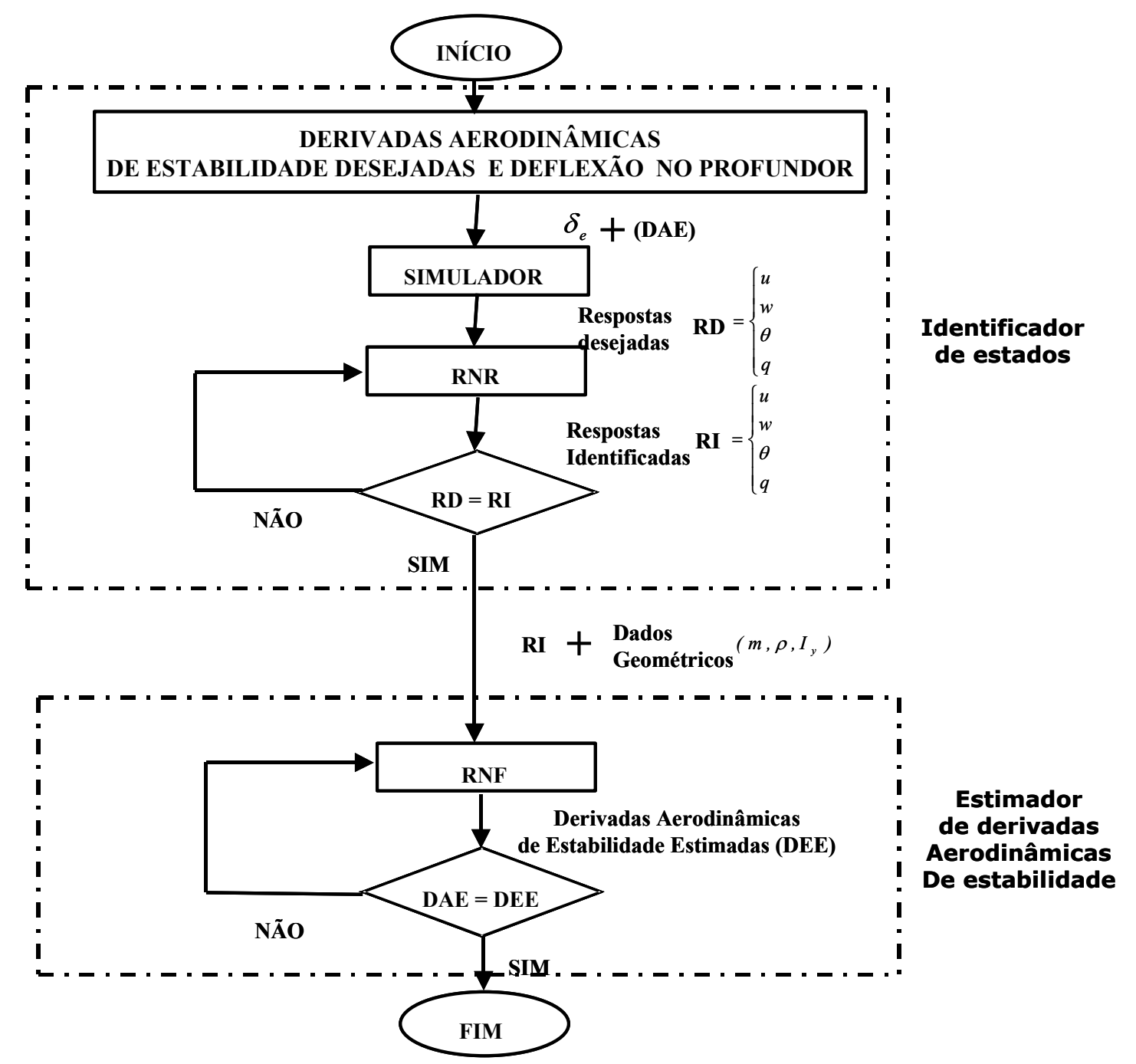

Figura 5.1. Diagrama de blocos mostrando a identificação das respostas da aeronave e suas respectivas derivadas. 


\subsection{Resultados da estimação das derivadas aerodinâmicas da aeronave de ataque simulada} A4-D

Para obter um conjunto de treinamento representativo da dinâmica da aeronave para a rede neural, várias condições de vôo correspondentes a cada um dos casos mostrados no envelope de vôo foram simuladas usando diferentes entradas de profundor. Foram usadas entradas do tipo trem de pulsos, senoidal, degrau e aleatória. Foram simulados 3 conjuntos de dados para cada uma das condições do envelope de vôo.

A princípio foi implementada apenas uma RNA para estimar as derivadas aerodinâmicas longitudinais da aeronave, mas devido ao número muito grande de entradas na rede, isto é, devido ao alto custo computacional e ao fato de que cada derivada é influenciada por entradas distintas, optou-se por implementar RNA's separadas. Foram implementadas uma RNA para estimar as derivadas em $u$, no caso, $X_{u}, Z_{u}$ e $M_{u}$, outra para estimar as derivadas em $w, X_{w}, Z_{w}$ e $M_{w}$ e uma outra para estimar as derivadas $M_{\dot{w}}$ e $M_{q}$. Ambas as arquiteturas usadas foram do tipo estáticas, ou seja, feedforward, com duas camadas intermediárias de neurônios e para treiná-las foi usado o algoritmo backpropagation. Em todas as RNA's foram usados também dois tipos de entradas: dinâmicas, no caso respostas de velocidades da aeronave e entradas estáticas, especificamente:

- $\quad$ massa da aeronave (m);

- momento de inércia $\mathrm{I}_{\mathrm{y}}$

- densidade do ar $\rho$;

- $\quad$ velocidade inicial $\mathrm{U}_{0}$;

- Mach M.

Destaca-se que foi usado o software Matlab ${ }^{\circledR}$ para trabalhar com as redes neurais.

\subsubsection{Resultados da estimação das derivadas aerodinâmicas longitudinais $X_{u}, Z_{u}$ e $M_{u}$}

Para estimar $X_{u}, Z_{u}$ e $M_{u}$, como dito anteriormente, além das entradas estáticas, foram usadas também entradas dinâmicas, neste caso, respostas no tempo de variações da velocidade linear $u$ e da velocidade angular $q$. Estes sinais no tempo foram discretizados e considerou-se 1 ponto a cada 50 do total de 10000 pontos, formando-se dois vetores de tamanho 200 com estes 
sinais para fornecer como entrada à RNA. Pôde-se verificar que fazendo essa discretização os sinais continuaram caracterizados. A Figura 5.2 apresenta um diagrama de blocos representativo desta rede neural usada. As entradas fornecidas para a RNA foram escolhidas depois de vários testes realizados e inclusive em alguns deles foram acrescentadas variações de $w$, mas sem sucesso.

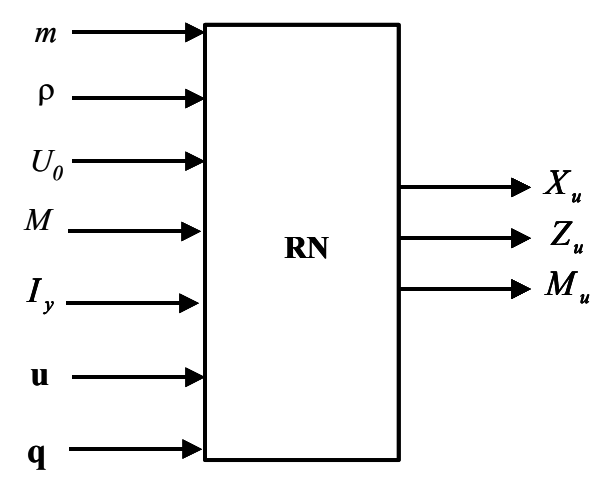

Figura 5.2. Diagrama de blocos representativo da RNA usada para estimar as derivadas longitudinais em $u$.

Escolhidas as entradas, o próximo passo foi então escolher a topologia da rede neural a ser usada. Primeiramente foi implementada uma rede neural com 3 camadas de neurônios: a primeira para receber as entradas da rede, uma camada intermediária com 20 e uma de saída com 3 neurônios. Foram usadas as funções de ativação tangente sigmoidal (sigmóide) e linear respectivamente nas conexões da camada de entrada com a intermediária e desta com a de saída. Para usar estas funções, como todos os dados variavam dentro de intervalos bastante diferentes, foi necessário normalizá-los, dividindo cada um dos conjuntos de dados pelo seu máximo valor absoluto, pois a função de ativação sigmóide, apresentada no Capítulo 3, sempre varia entre -1 e 1 . Escolhida a topologia, foram realizados testes de treinamento encontrando resultados razoáveis.

Vários outros testes foram realizados variando o número de neurônios nas camadas, variando as funções de ativação e em alguns deles foi acrescentada mais uma camada intermediária. Serão agora apresentados os resultados de treinamento e de generalização de dois testes realizados com RNA's com duas camadas intermediárias e 12-11-3 e 30-28-3 neurônios respectivamente nas camadas intermediárias e de saída. As funções de ativação usadas, em ambas as redes, foram não lineares sigmóides respectivamente das conexões da camada de entrada com a primeira intermediária e desta com a segunda intermediária e função linear da segunda intermediária com a de saída. Como feito na identificação das respostas da aeronave, mostrado no 
Capítulo 4, para treinar a RNA foram usados os dados correspondentes aos Casos 5, 6, 8 e 9 do envelope de vôo cujo esquema está apresentado novamente na Figura 5.3.

A Figura 5.4 mostra o decaimento do erro em função do número de épocas das duas topologias citadas anteriormente. A taxa de aprendizagem usada nas duas redes foi de 0,04 . Podese observar que ambas tiveram desempenho bastante satisfatórios.

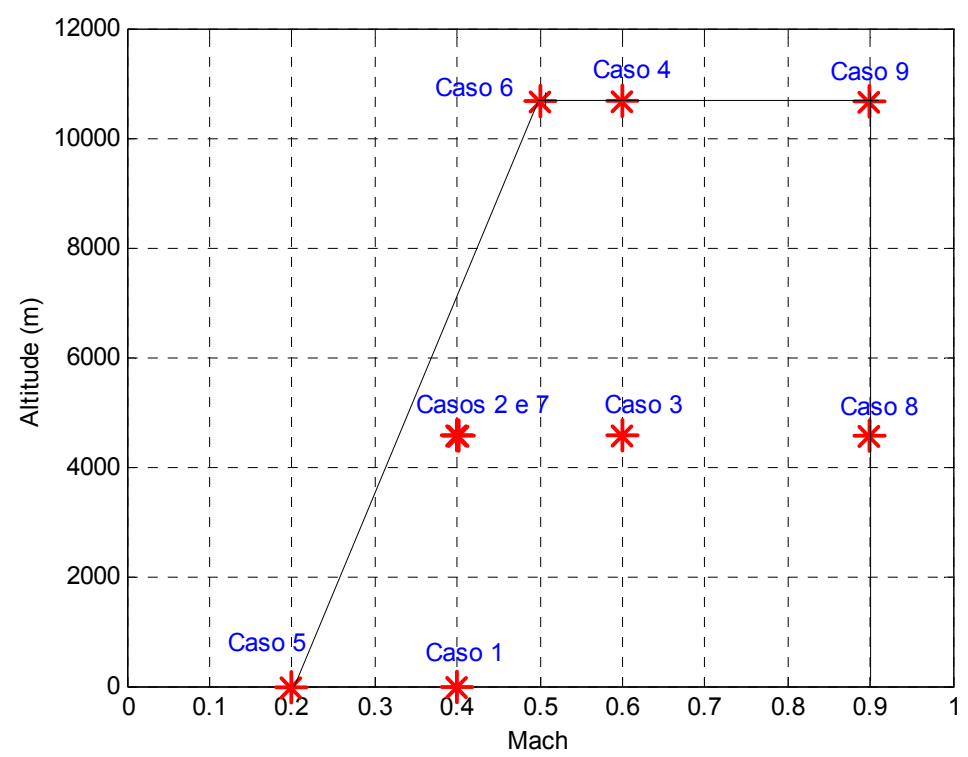

Figura 5.3 Esquema representativo dos pontos do envelope de vôo simulados.

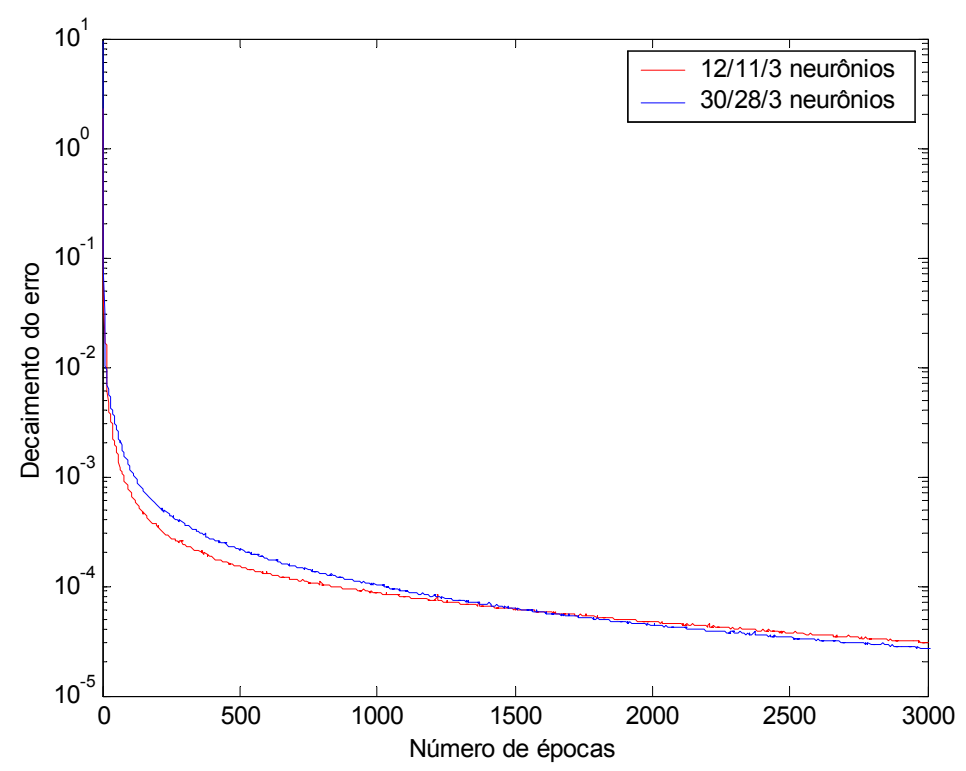

Figura 5.4. Decaimento do erro de treinamento nas RNA's usadas. 
100

Primeiramente serão mostrados os resultados das derivadas de estabilidade estimadas pela RNA com topologia 30-28-3 neurônios. Nas Tabelas 5.1, 5.2 e 5.3 estão os resultados do treinamento da RNA e nas Tabelas de 5.4, 5.5 e 5.6 estão apresentados os resultados das derivadas estimadas (generalizadas) pela rede neural relativa aos outros casos do envelope de vôo.

Visando quantificar os valores estimados, foi calculado o erro quadrático médio entre as derivadas desejadas e estimadas. O erro quadrático é calculado elevando-se ao quadrado o resultado da diferença entre o valor estimado e o valor desejado. Fazendo-se isto para cada valor desejado e estimado, somando cada erro e depois dividindo pelo total de medidas, obtém-se o erro quadrático médio.

\begin{tabular}{|c|c|c|c|c||}
\hline$X_{u}(\mathrm{Kg} / \mathrm{s})$ & CASO 5 & CASO 6 & CASO 8 & CASO 9 \\
\hline Real & $-847,33$ & $-143,6$ & $-506,20$ & $-281,4$ \\
\hline Estimado & $-848,52$ & $-144,63$ & $-506,22$ & $-281,45$ \\
\hline
\end{tabular}

Tabela 5.1. Resultados de $X_{u}$ obtidos em treinamento e teóricos.

\begin{tabular}{|c|c|c|c|c||}
\hline$Z_{u}(\mathrm{Kg} / \mathrm{s})$ & CASO 5 & CASO 6 & CASO 8 & CASO 9 \\
\hline Real & $-2667,1$ & $-1098,9$ & $-1076,2$ & $-956,6$ \\
\hline Estimado & $-2679,9$ & $-1089,1$ & $-1.075,5$ & $-956,3$ \\
\hline
\end{tabular}

Tabela 5.2. Resultados de $Z_{u}$ obtidos em treinamento e teóricos.

\begin{tabular}{|c|c|c|c|c||}
\hline \hline$M_{u}(\mathrm{Kg} . \mathrm{m} / \mathrm{s})$ & CASO 5 & CASO 6 & CASO 8 & CASO 9 \\
\hline Real & 377,9 & 61,4 & $-1094,2$ & $-575,9$ \\
\hline Estimado & 378,3 & 61,4 & $-1094,5$ & $-576,1$ \\
\hline
\end{tabular}

Tabela 5.3. Resultados de $M_{u}$ obtidos em treinamento e teóricos.

Calculando os erros quadráticos médios para os dados apresentados nas Tabelas 5.1, 5.2 e 5.3, respectivamente referentes a $X_{u}, Z_{u}$ e $M_{u}$, os resultados obtidos foram 0,62, 65,1 e 0,07 .

Após verificação dos resultados obtidos em treinamento, foram apresentados à rede, valores por ela desconhecidos correspondentes aos casos 1, 2, 3, 4 e 7 respectivamente, para verificar seu poder de generalização e os resultados estão apresentados nas Tabelas 5.4, 5.5 e 5.6. 


\begin{tabular}{||l|l|l|l|l|l||}
\hline$X_{u}(\mathrm{Kg} / \mathrm{s})$ & CASO 1 & CASO 2 & CASO 3 & CASO 4 & CASO 7 \\
\hline Real & $-108,95$ & $-109,80$ & $-126,14$ & -126 & $-127,5$ \\
\hline Estimado & $-110,95$ & $-111,03$ & -127 & -177 & $-128,4$ \\
\hline \hline
\end{tabular}

Tabela 5.4. Resultados de $X_{u}$ estimados e teóricos.

\begin{tabular}{|l|l|l|l|l|l||}
\hline \hline$Z_{u}(\mathrm{Kg} / \mathrm{s})$ & CASO 1 & CASO 2 & CASO 3 & CASO 4 & CASO 7 \\
\hline Real & $-970,4$ & $-885,3$ & $-1292,1$ & $-1361,9$ & $-1243,6$ \\
\hline Estimado & $-975,7$ & $-886,4$ & $-1161,4$ & $-1264,5$ & $-1064,5$ \\
\hline
\end{tabular}

Tabela 5.5. Resultados de $Z_{u}$ estimados e teóricos.

\begin{tabular}{|l|l|l|l|l|l||}
\hline$M_{u}(\mathrm{Kg} \cdot \mathrm{m} / \mathrm{s})$ & CASO 1 & CASO 2 & CASO 3 & CASO 4 & CASO 7 \\
\hline Real & 46,07 & 46,07 & 53,9 & 57,6 & 46 \\
\hline Estimado & 45,71 & 43,8 & 52,6 & 63,17 & 55 \\
\hline
\end{tabular}

Tabela 5.6. Resultados de $M_{u}$ estimados e teóricos.

Análogo ao feito anteriormente, foram calculados os erros quadráticos médios entre as derivadas desejadas e as estimadas pela RNA, obtendo-se para $X_{u}, Z_{u}$ e $M_{u}$ respectivamente $521,6,11735$ e 23,8 .

Para uma melhor visualização dos resultados, foram plotados valores desejados contra valores obtidos mostrados na Figura 5.5.
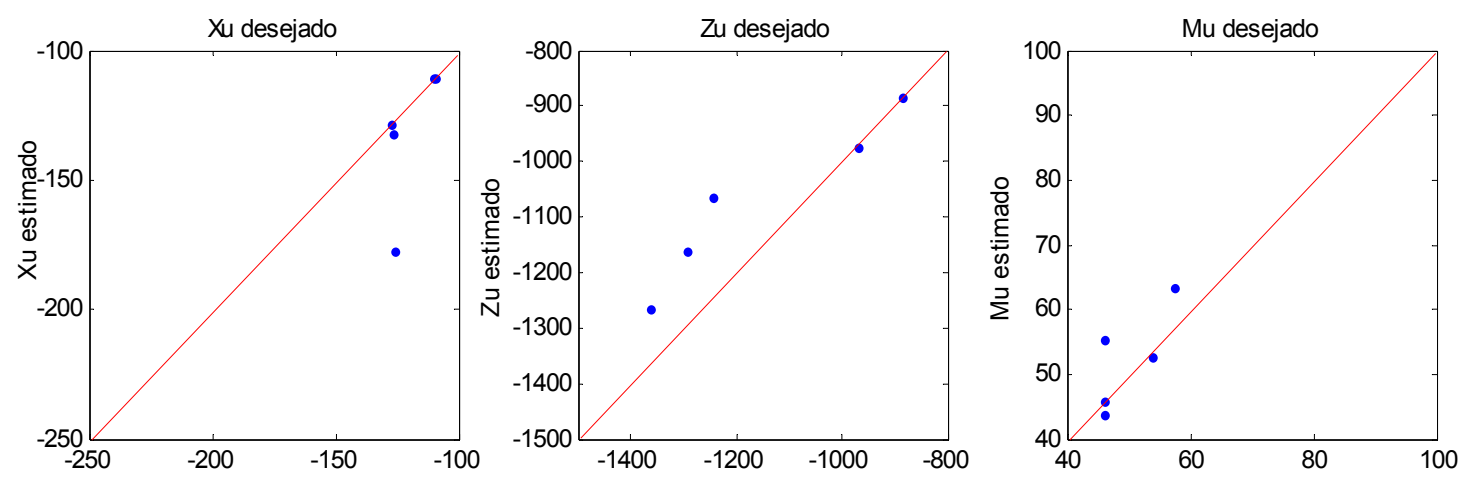

Figura 5.5. Respostas das derivadas estimadas e teóricas. 
102

Num segundo teste, foi diminuído de 30 para 12 e de 28 para 11 neurônios na primeira e segunda camada intermediárias respectivamente. Os resultados de generalização estão mostrados nas Tabelas 5.7, 5.8 e 5.9 e os erros quadráticos médios encontrados relativos a estes resultados, respectivamente, foram $91,8,70.718$ e 57,3 .

\begin{tabular}{||l|l|l|l|l|l||}
\hline \hline$X_{u}(\mathrm{Kg} / \mathrm{s})$ & CASO 1 & CASO 2 & CASO 3 & CASO 4 & CASO 7 \\
\hline Real & $-108,95$ & $-109,80$ & $-126,14$ & -126 & $-127,5$ \\
\hline Estimado & $-111,4$ & $-102,4$ & $-126,4$ & $-145,4$ & $-122,8$ \\
\hline
\end{tabular}

Tabela 5.7. Resultados de $X_{u}$ estimados e teóricos.

\begin{tabular}{|l|l|l|l|l|l||}
\hline$Z_{u}(\mathrm{Kg} / \mathrm{s})$ & CASO 1 & CASO 2 & CASO 3 & CASO 4 & CASO 7 \\
\hline Real & $-970,4$ & $-885,3$ & $-1292,1$ & $-1361,9$ & $-1243,6$ \\
\hline Estimado & $-981,5$ & $-880,8$ & $-896,2$ & $-1023,5$ & $-1530,3$ \\
\hline
\end{tabular}

Tabela 5.8. Resultados de $Z_{u}$ estimados e teóricos.

\begin{tabular}{|l|l|l|l|l|l||}
\hline$M_{u}(\mathrm{Kg} . \mathrm{m} / s)$ & CASO 1 & CASO 2 & CASO 3 & CASO 4 & CASO 7 \\
\hline Real & 46,07 & 46,07 & 53,9 & 57,6 & 46 \\
\hline Estimado & 46,7 & 48,6 & 65,02 & 70 & 44,4 \\
\hline
\end{tabular}

Tabela 5.9. Resultados de $M_{u}$ estimados e teóricos.

A Figura 5.6 mostra as comparações entre valores desejados e estimados para as três respostas de derivadas em $u$, para este segundo teste realizado.
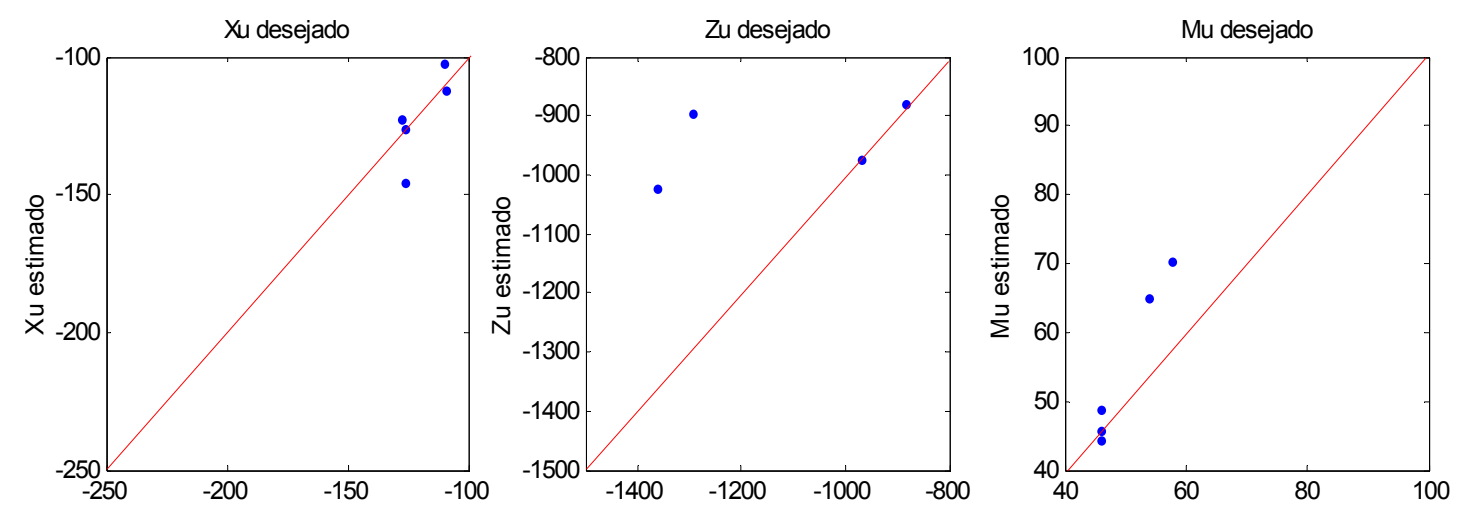

Figura 5.6. Comparação das respostas das derivadas estimadas e teóricas. 
Pôde-se observar que diminuindo o número de neurônios da primeira camada, o resultado geral foi menos preciso. Vários outros testes foram realizados, mas não serão mostrados por apresentarem resultados bastante próximos dos vistos nestes dois.

\subsubsection{Resultado da estimação das derivadas aerodinâmicas longitudinais $M_{\dot{w}}$ e $M_{q}$}

Novamente serão usados para treinamento as respostas da aeronave nos pontos $5,6,8$ e 9 do envelope de vôo e serão verificadas as respostas da rede para os Casos 1, 2, 3, 4 e 7 respectivamente. Como entradas para a rede neural para obter as derivadas $M_{\dot{w}} e M_{q}$, serão usadas as respostas de variações de $w$ e $q$ também discretas no tempo, representadas por vetores com 200 pontos e os dados estáticos, representando características da aeronave em cada ponto do envelope. A Figura 5.7 mostra o diagrama de blocos representativo desta rede neural.

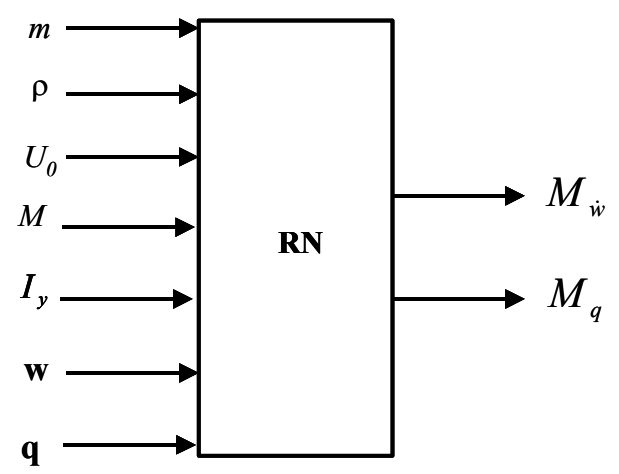

Figura 5.7. Diagrama de blocos mostrando a esquema da RNA usada para estimar as derivadas longitudinais $M_{\dot{w}}$ e $M_{q}$.

A primeira arquitetura testada apresentava 11-8-2 neurônios nas camadas intermediárias e de saída respectivamente. Vários outros testes foram realizados e analisados e todos apresentaram resultados bastante análogos aos deste, adotando-se portanto este primeiro modelo para estimar $M_{\dot{w}}$ e $M_{q}$. Nas Tabelas 5.10 e 5.11 estão mostrados os resultados desejados e os resultados obtidos durante o treinamento desta rede. A curva representativa do decaimento do erro deste treinamento está apresentada na Figura 5.8. 


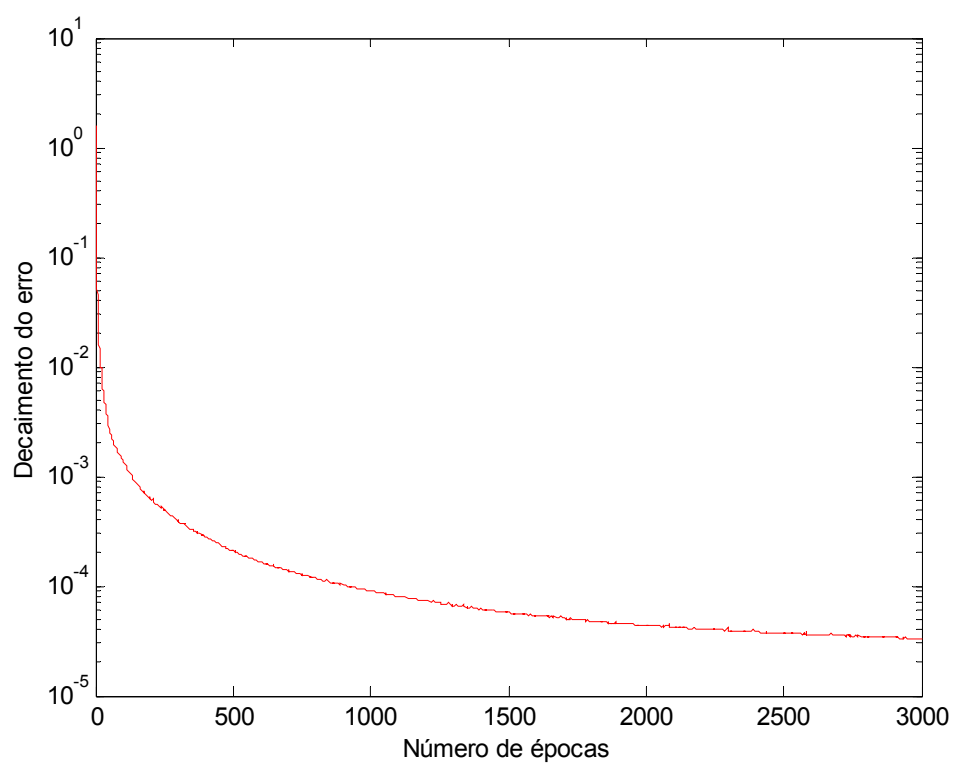

Figura 5.8. Decaimento do erro de treinamento da rede neural usada.

\begin{tabular}{||l|l|l|l|l||}
\hline$M_{\dot{w}}($ Kg.m $)$ & CASO 5 & CASO 6 & CASO 8 & CASO 9 \\
\hline Real & $-84,17$ & $-29,14$ & $-103,80$ & $-51,14$ \\
\hline Estimado & $-83,87$ & $-29,12$ & $-103,81$ & $-51,14$ \\
\hline
\end{tabular}

Tabela 5.10. Comparação dos valores de $M_{\dot{w}}$ obtidos em treinamento com teóricos.

\begin{tabular}{||l|l|l|l|l||}
\hline$M_{q}\left(K g \cdot m^{2} / s\right)$ & CASO 5 & CASO 6 & CASO 8 & CASO 9 \\
\hline Real & -19063 & -13656 & -67896 & -30753 \\
\hline Estimado & -19386 & -13590 & -67891 & -30752 \\
\hline
\end{tabular}

Tabela 5.11. Comparação dos valores de $M_{q}$ obtidos em treinamento com teóricos.

Os erros quadráticos médios obtidos para $M_{\dot{w}}$ e $M_{q}$ foram 0,0226 e 27178 respectivamente. Pode-se observar a diferença entre os valores de erros obtidos e isto se deve à considerável diferença de ordem entre as derivadas.

Para verificar a generalização da rede neural, foram apresentadas entradas correspondentes aos casos 1, 2, 3, 4 e 7 respectivamente e como mostram as Tabelas 5.12 e 5.13 os resultados de generalização foram bastante satisfatórios. Os valores dos erros quadráticos médios encontrados foram para $M_{\dot{w}}$ e $M_{q}$ foram aproximadamente 4,9 e 1832500 respectivamente. 


\begin{tabular}{|l|l|l|l|l|l||}
\hline$M_{\dot{w}}(\mathrm{Kg} \cdot \mathrm{m})$ & CASO 1 & CASO 2 & CASO 3 & CASO 4 & CASO 7 \\
\hline Real & $-31,56$ & $-64,13$ & $-55,5$ & $-55,54$ & $-88,1$ \\
\hline Estimado & $-31,7$ & $-63,8$ & $-50,6$ & $-54,8$ & $-90,3$ \\
\hline \hline
\end{tabular}

Tabela 5.12. Resultados de $M_{\dot{w}}$ estimados e teóricos.

\begin{tabular}{||l|l|l|l|l|l||}
\hline \hline$M_{q}\left(\mathrm{Kg} \cdot \mathrm{m}^{2} / \mathrm{s}\right)$ & CASO 1 & CASO 2 & CASO 3 & CASO 4 & CASO 7 \\
\hline Real & -16991 & -37599 & -23521 & -23521 & -40407 \\
\hline Estimado & -16998 & -30600 & -25549 & -29728 & -31621 \\
\hline
\end{tabular}

Tabela 5.13. Resultados de $M_{q}$ estimados e teóricos.

Para facilitar a visualização da coerência dos resultados, será apresentado na Figura 5.9 um gráfico comparativo das respostas desejadas e obtidas. Como pode-se observar pelos valores numéricos e pelos erros, os valores de $M_{\dot{w}}$ e $M_{q}$ estimados foram satisfatórios, mas o erro quadrático médio obtido entre as derivadas $M_{q}$, estimadas e reais, foi bastante significativo.
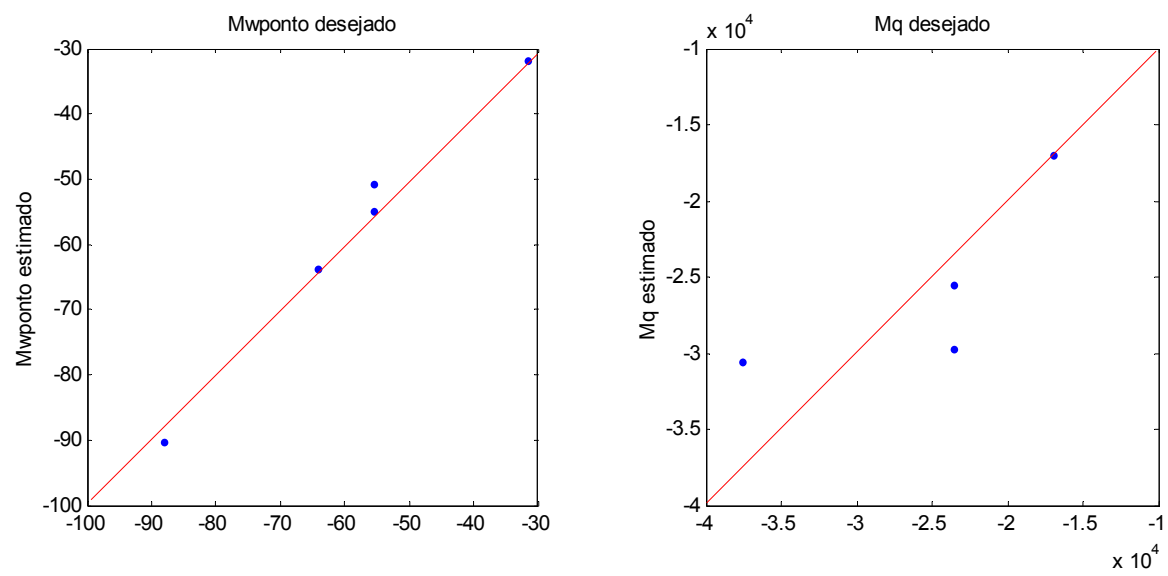

Figura 5.9. Respostas referentes às derivadas estimadas e teóricas.

\subsubsection{Resultado da estimação das derivadas aerodinâmicas longitudinais $X_{w}, Z_{w}$ e $M_{w}$}

Para estimar as derivadas $X_{w}, Z_{w}$ e $M_{w}$, num primeiro teste foi implementada uma RNA usando como entradas dinâmicas, variações de $w$ e $q$ e como entradas estáticas as mesmas usadas nas outras RNA's anteriormente apresentadas. Os resultados obtidos não foram satisfatórios. Em seguida foram fornecidas todas estas entradas citadas anteriormente juntamente com o vetor $u$ e os 
resultados melhoraram significantemente. O esquema da rede neural usada está mostrado na Figura 5.10 num diagrama de blocos.

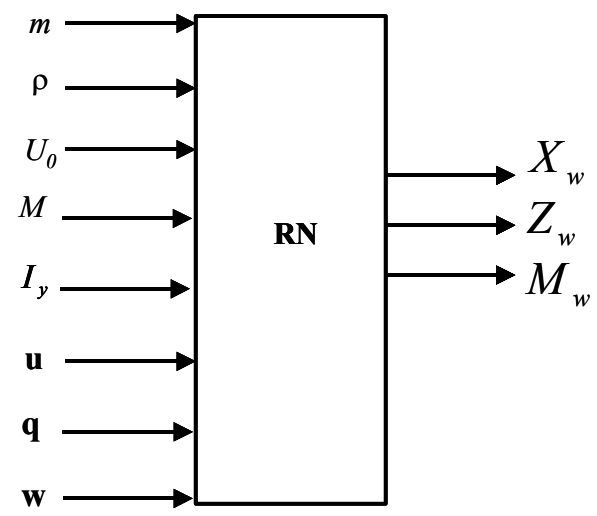

Figura 5.10. Diagrama de blocos mostrando a rede neural para estimar as derivadas longitudinais

$$
X_{w}, Z_{w} \text { e } M_{w}
$$

Novamente usou-se uma rede neural feedforward e estática, ou seja, sem atrasos no tempo. Primeiramente, serão apresentados os resultados obtidos no treinamento de uma rede com 30-18-3 neurônios respectivamente nas camadas intermediárias e de saída e taxa de aprendizagem 0,02. A Figura 5.11 mostra o decaimento do erro e pode-se observar que foi bastante satisfatório.

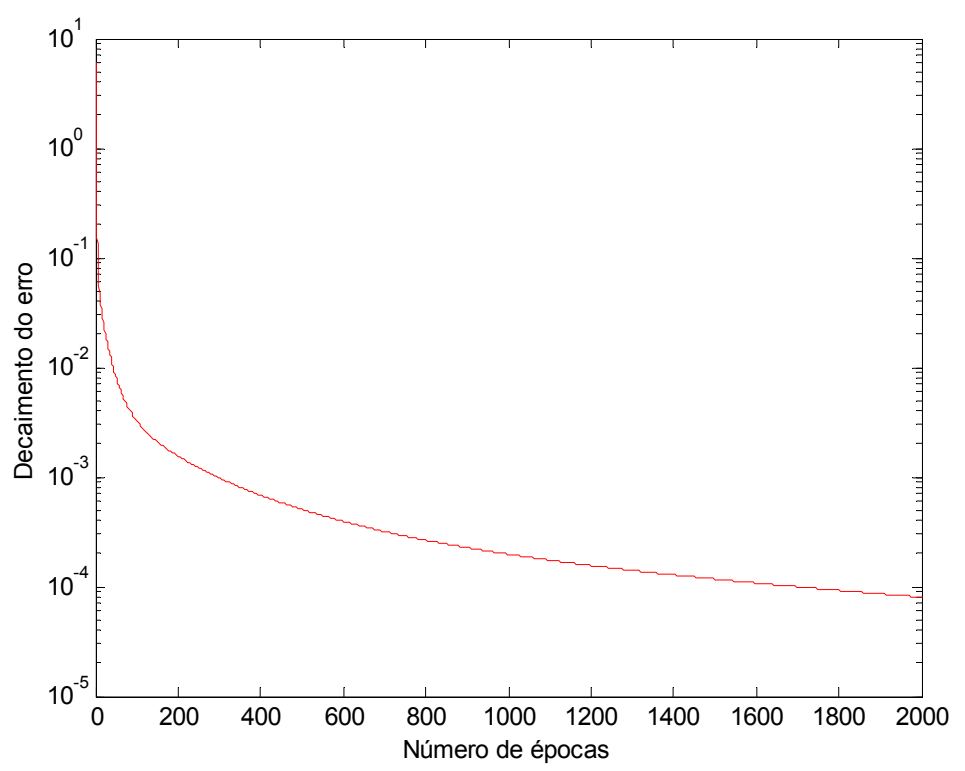

Figura 5.11. Decaimento do erro de treinamento da rede neural usada.

As respostas do treinamento desta rede estão apresentadas nas Tabelas 5.14, 5.15 e 5.16. Novamente calculou-se os valores dos erros quadráticos médios encontrando-se 26,0656, 882,5 e 527050 respectivamente para $X_{w}, Z_{w}$ e $M_{w}$. 


\begin{tabular}{||l|l|l|l|l||}
\hline$X_{w}(\mathrm{Kg} / s)$ & CASO 5 & CASO 6 & CASO 8 & CASO 9 \\
\hline Real & $-320,05$ & $-287,7$ & $-379,1$ & -428 \\
\hline Estimado & $-329,3$ & $-286,8$ & $-383,3$ & $-427,5$ \\
\hline
\end{tabular}

Tabela 5.14. $X_{w}$ obtidos em treinamento e teóricos.

\begin{tabular}{||l|l|l|l|l||}
\hline$Z_{w}(\mathrm{Kg} / \mathrm{S})$ & CASO 5 & CASO 6 & CASO 8 & CASO 9 \\
\hline Real & -3149 & -1796 & -11761 & -5339 \\
\hline Estimado & -3151 & -1763 & -11712 & -5333 \\
\hline
\end{tabular}

Tabela 5.15. $Z_{w}$ obtidos em treinamento e teóricos.

\begin{tabular}{||l|l|l|l|l||}
\hline$M_{w}(\mathrm{Kg} \cdot \mathrm{m} / \mathrm{s})$ & CASO 5 & CASO 6 & CASO 8 & CASO 9 \\
\hline Real & -13290 & -8742 & -43506 & -19709 \\
\hline Estimado & -13132 & -8371 & -42397 & -18863 \\
\hline
\end{tabular}

Tabela 5.16. $M_{w}$ obtidos em treinamento e teóricos.

Agora serão apresentados os resultados da estimação das derivadas correspondentes aos Casos 1, 2, 3, 4 e 5 respectivamente nas Tabelas 5.17, 5.18 e 5.19 .

\begin{tabular}{||l|l|l|l|l|l||}
\hline$X_{w}(\mathrm{Kg} / \mathrm{s})$ & CASO 1 & CASO 2 & CASO 3 & CASO 4 & CASO 7 \\
\hline Real & $-49,95$ & $-300,4$ & $-315,8$ & $-250,7$ & -31 \\
\hline Estimado & $-209,5$ & $-247,7$ & $-221,3$ & $-285,5$ & $-25,5$ \\
\hline
\end{tabular}

Tabela 5.17. Resultados de $X_{w}$ estimados e teóricos.

\begin{tabular}{||l|l|l|l|l|l||}
\hline$Z_{w}(\mathrm{Kg} / \mathrm{s})$ & CASO 1 & CASO 2 & CASO 3 & CASO 4 & CASO 7 \\
\hline Real & $-6966,8$ & $-3181,8$ & $-4426,3$ & $-4419,1$ & $-7106,7$ \\
\hline Estimado & $-5137,0$ & $-2907,1$ & $-4835,9$ & $-4487,9$ & $-7098,4$ \\
\hline
\end{tabular}

Tabela 5.18. Resultados de $Z_{w}$ estimados e teóricos.

\begin{tabular}{|l|l|l|l|l|l||}
\hline$M_{w}(\mathrm{Kg} . \mathrm{m} / s)$ & CASO 1 & CASO 2 & CASO 3 & CASO 4 & CASO 7 \\
\hline Real & $-2356,2$ & $-1065,4$ & $-1541,1$ & $-1535,4$ & $-2636,7$ \\
\hline Estimado & $-2048,5$ & $-1365,9$ & $-1841,8$ & $-1509,6$ & $-2599,7$ \\
\hline
\end{tabular}

Tabela 5.19. Resultados de $M_{w}$ estimados e teóricos. 
Novamente visando uma análise quantitativa da proximidade entre as derivadas de estabilidade desejadas e estimadas, foram calculados os erros quadráticos médios obtendo-se 7681, 719240 e 55487 . A Figura 5.12 mostra o gráfico representativo dos resultados obtidos por esta rede.
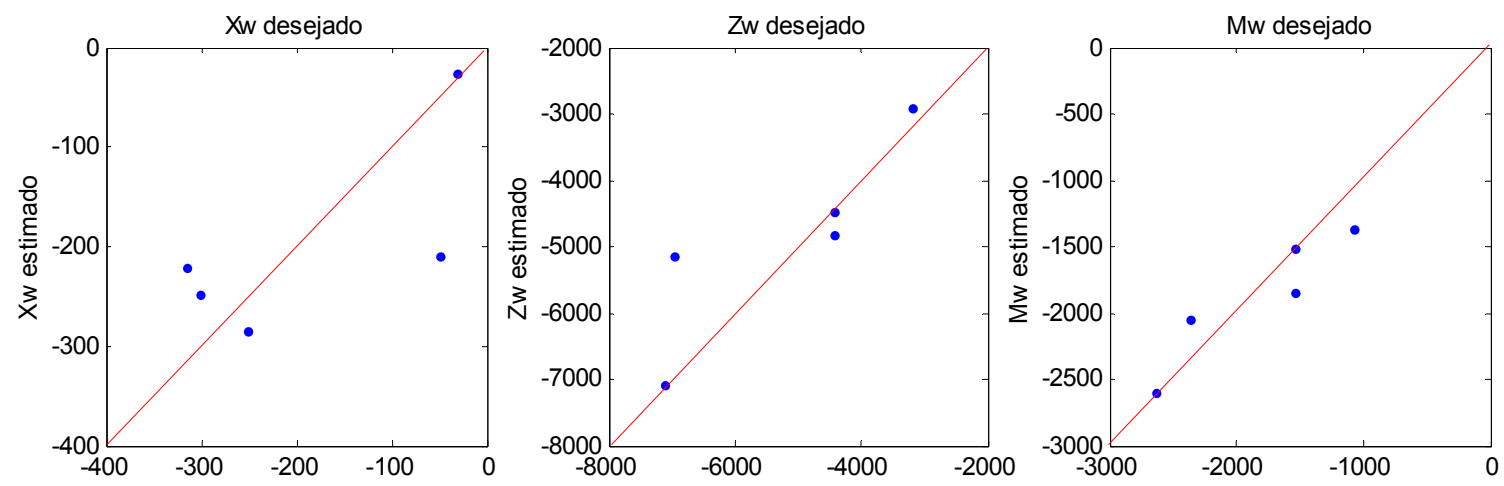

Figura 5.12. Respostas das derivadas estimadas e teóricas.

Como pode-se observar, o problema maior apresentado foi referente à estimação de $X_{w}$ para o Caso 1.

Um segundo teste foi realizado usando 10, 8 e 3 neurônios nas camadas intermediárias e de saída. Na Figura 5.13 pode-se observar a curva de decaimento do erro e pode-se verificar que atingiu valor menor que o da rede anterior com topologia 30-18-3.

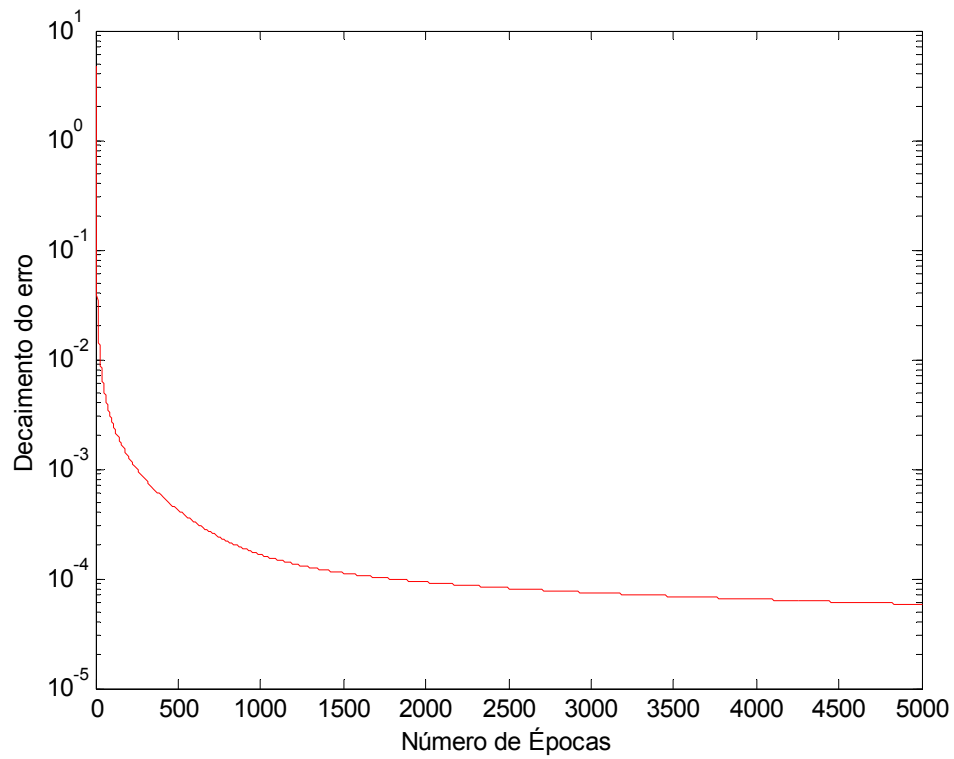

Figura 5.13. Decaimento do erro de treinamento da rede neural usada. 
Novamente foram plotados gráficos comparativos das respostas desejadas e estimadas e estão mostrados na Figura 5.14.
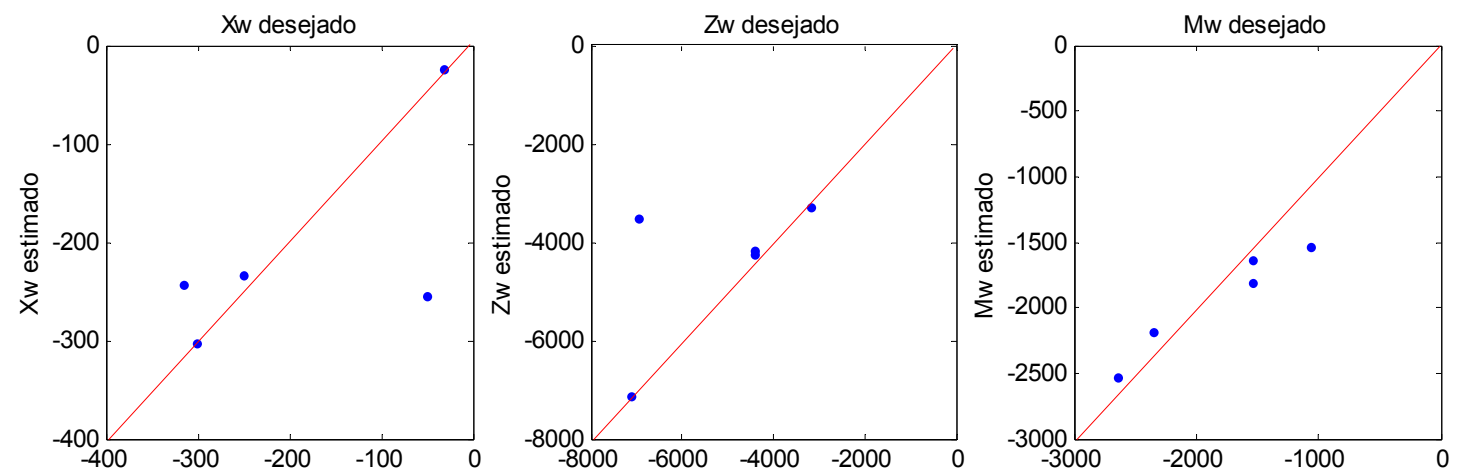

Figura 5.14. Respostas das derivadas estimadas e teóricas.

Os valores obtidos quando foram apresentados dados dos casos desconhecidos da rede estão mostrados nas Tabelas 5.20, 5.21 e 5.22 e os erros quadráticos médios entre as derivadas estimadas e desejadas foram respectivamente $9520,7,2416300$ e 67902 para $X_{w}, Z_{w}$ e $M_{w}$.

\begin{tabular}{|l|l|l|l|l|l||}
\hline$X_{w}(\mathrm{Kg} / \mathrm{s})$ & CASO 1 & CASO 2 & CASO 3 & CASO 4 & CASO 7 \\
\hline Real & $-49,95$ & $-300,4$ & $-315,8$ & $-250,7$ & -31 \\
\hline Estimado & $-254,8$ & $-302,9$ & $-243,1$ & $-233,7$ & $-23,3$ \\
\hline
\end{tabular}

Tabela 5.20. Resultados das derivadas $X_{w}$ estimados e teóricos.

\begin{tabular}{|l|l|l|l|l|l||}
\hline$Z_{w}(\mathrm{Kg} / \mathrm{s})$ & CASO 1 & CASO 2 & CASO 3 & CASO 4 & CASO 7 \\
\hline Real & $-6966,8$ & $-3181,8$ & $-4426,3$ & $-4419,1$ & $-7106,7$ \\
\hline Estimado & -3508 & -3290 & -4154 & -4240 & -7119 \\
\hline \hline
\end{tabular}

Tabela 5.21. Resultados das derivadas $Z_{w}$ estimados e teóricos.

\begin{tabular}{|l|l|l|l|l|l||}
\hline$M_{w}(\mathrm{Kg} . \mathrm{m} / s)$ & CASO 1 & CASO 2 & CASO 3 & CASO 4 & CASO 7 \\
\hline Real & $-2356,2$ & $-1065,4$ & $-1541,1$ & $-1535,4$ & $-2636,7$ \\
\hline Estimado & $-2179,9$ & $-1530,9$ & $-1805,0$ & $-1638,9$ & $-2530,0$ \\
\hline
\end{tabular}

Tabela 5.22. Resultados das derivadas $M_{w}$ estimados e teóricos.

Pode-se observar então que no geral a RNA anterior com 30-18-3 neurônios apresentou resultados melhores, portanto serão os resultados desta que serão usados para simulação. 


\subsection{Comparação das respostas da aeronave usando as derivadas teóricas e estimadas}

Para verificar a representatividade das derivadas estimadas, estas serão usadas então no simulador visando comparar as respostas da aeronave usando as derivadas teóricas e as respostas usando as derivadas estimadas. As derivadas que serão usadas para simular o comportamento da aeronave estão apresentadas na Tabela 5.23.

Primeiramente serão apresentados resultados de simulação da aeronave usando os dados referentes ao caso 1 apresentado no envelope de vôo. Usando a entrada nos profundores mostrada na Figura 5.15, foi simulado o comportamento da aeronave e comparadas as respostas das variações da velocidade horizontal $u$, vertical $w$ e de arfagem $q$. Os resultados se mostraram satisfatórios como pode ser observado nas Figuras 5.16, 5.17 e 5.18.

\begin{tabular}{|l|l|l|l|l|l||}
\hline DERIVADAS & CASO 1 & CASO 2 & CASO 3 & CASO 4 & CASO 7 \\
\hline$X_{w}$ desejado & $-49,95$ & $-300,4$ & $-315,8$ & $-250,7$ & -31 \\
$X_{w}$ estimado & $-209,5$ & $-247,7$ & $-221,3$ & $-285,5$ & $-25,5$ \\
\hline$Z_{w}$ desejado & $-6966,8$ & $-3181,8$ & $-4426,3$ & $-4419,1$ & $-7106,7$ \\
$Z_{w}$ estimado & $-5137,0$ & $-2907,1$ & $-4835,9$ & $-4487,9$ & $-7098,4$ \\
\hline$M_{w}$ desejado & $-2356,2$ & $-1065,4$ & $-1541,1$ & $-1535,4$ & $-2636,7$ \\
$M_{w}$ estimado & $-2048,5$ & $-1365,9$ & $-1841,8$ & $-1509,6$ & $-2599,7$ \\
\hline$M_{\dot{w}}$ desejado & $-31,56$ & $-64,13$ & $-55,5$ & $-55,54$ & $-88,1$ \\
$M_{\dot{w}}$ estimado & $-31,7$ & $-63,8$ & $-50,6$ & $-54,8$ & $-90,3$ \\
\hline$M_{q}$ desejado & -16991 & -37599 & -23521 & -23521 & -40407 \\
$M_{q}$ estimado & -16998 & -30600 & -25549 & -29728 & -31621 \\
\hline$X_{u}$ desejado & $-108,95$ & $-109,80$ & $-126,14$ & -126 & $-127,5$ \\
$X_{u}$ estimado & $-111,4$ & $-102,4$ & $-126,4$ & $-145,4$ & $-122,8$ \\
\hline$Z_{u}$ desejado & $-970,4$ & $-885,3$ & $-1292,1$ & $-1361,9$ & $-1243,6$ \\
$Z_{u}$ estimado & $-981,5$ & $-880,8$ & $-896,2$ & $-1023,5$ & $-1530,3$ \\
\hline$M_{u}$ desejado & 46,07 & 46,07 & 53,9 & 57,6 & 46 \\
$M_{u}$ estimado & 46,7 & 48,6 & 65,02 & 70 & 44,4 \\
\hline \hline
\end{tabular}

Tabela 5.23. Resultados das derivadas estimadas e teóricas a serem usados para simulação. 

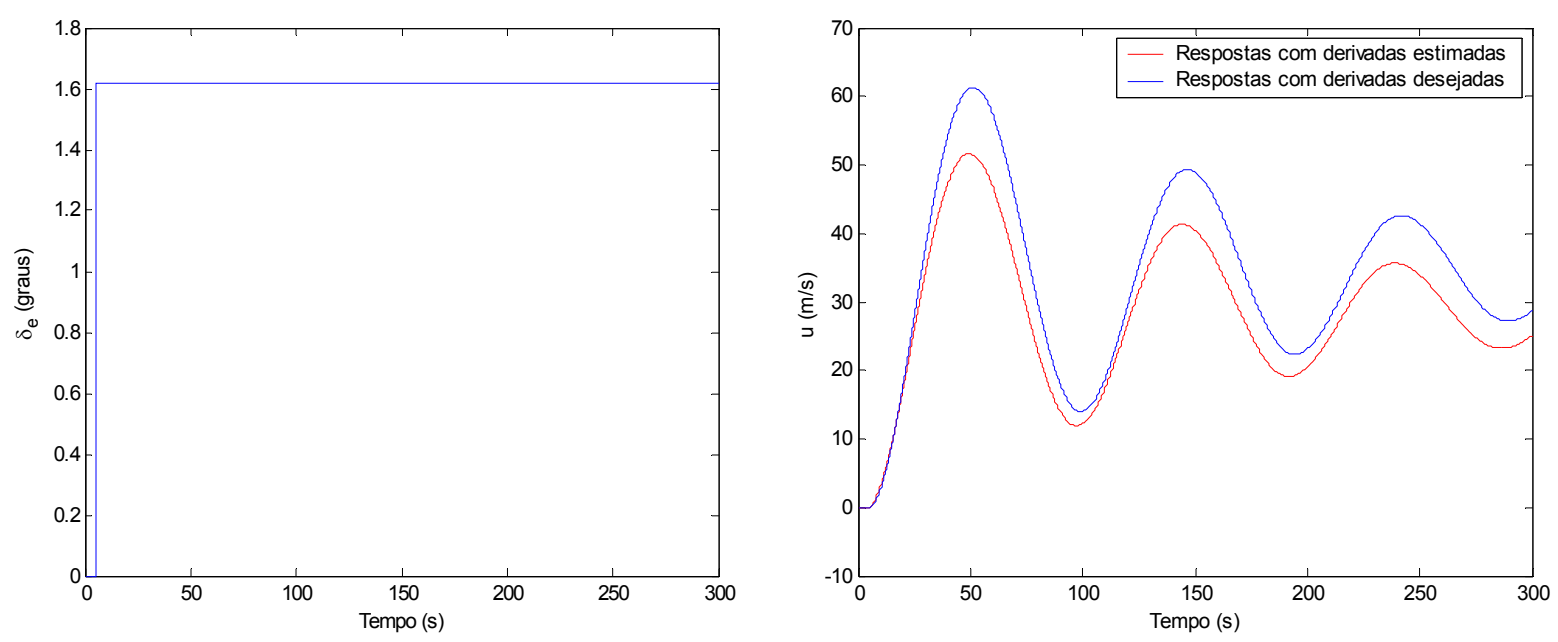

Figura 5.15. Entrada degrau usada no profundor.

Figura 5.16. Respostas de variação de $u$ usando derivadas teóricas e estimadas para o caso 1.

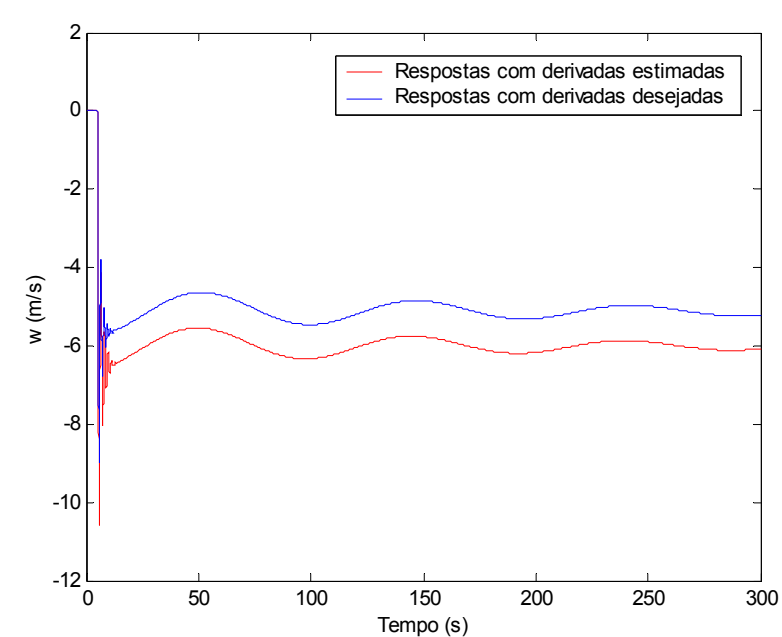

Figura 5.17. Respostas de variação de $w$ usando derivadas teóricas e estimadas para o caso 1.

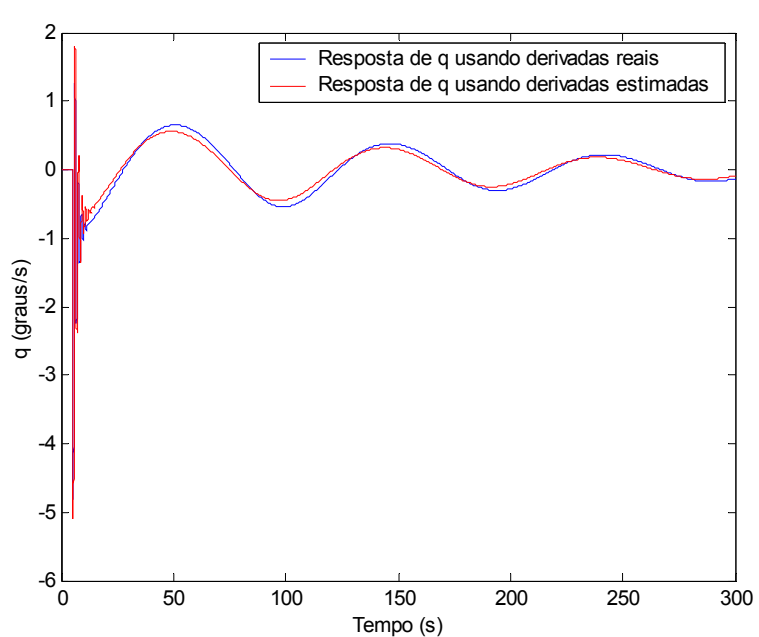

Figura 5.18. Respostas de variação de $q$ usando derivadas teóricas e estimadas para o caso 1.

Também para os dados referentes ao caso 1 do envelope de vôo, uma segunda simulação foi realizada visando comparar as respostas da aeronave usando as derivadas estimadas e teóricas, porém usando como entrada nos profundores um pulso adicionado de um ruído, como mostra a Figura 5.19. Os resultados observados também foram satisfatórios como pode-se observar nas Figuras 5.20, 5.21 e 5.22 . 


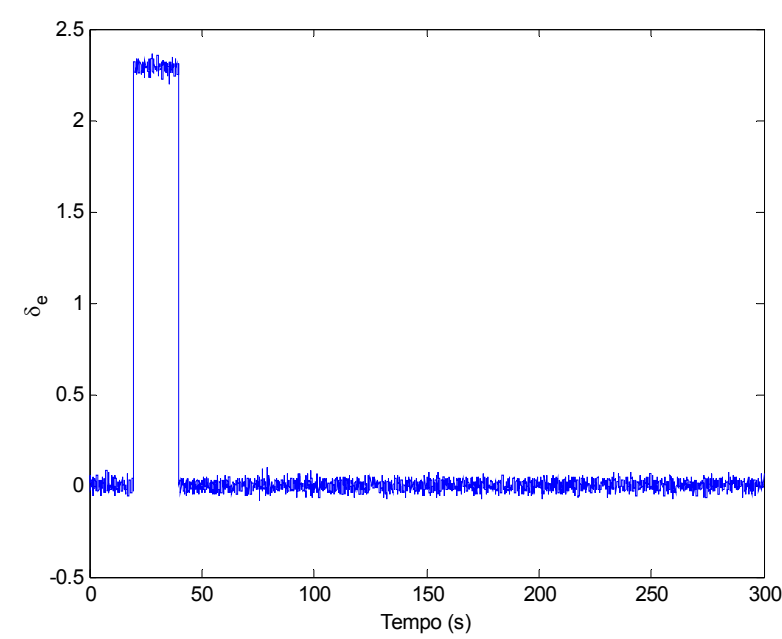

Figura 5.19. Entrada pulso juntamente com ruído usada no profundor.

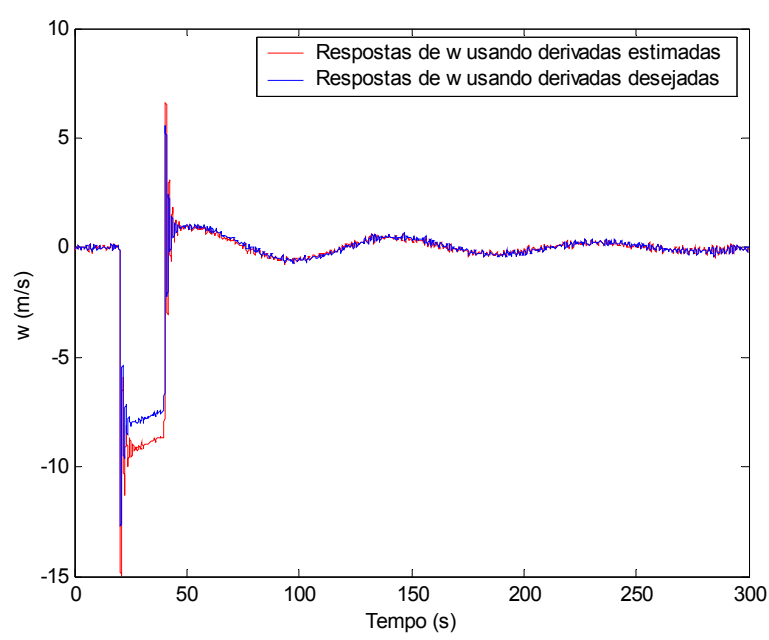

Figura 5.21. Respostas de variação de $w$ usando derivadas teóricas e estimadas para o caso 1 .

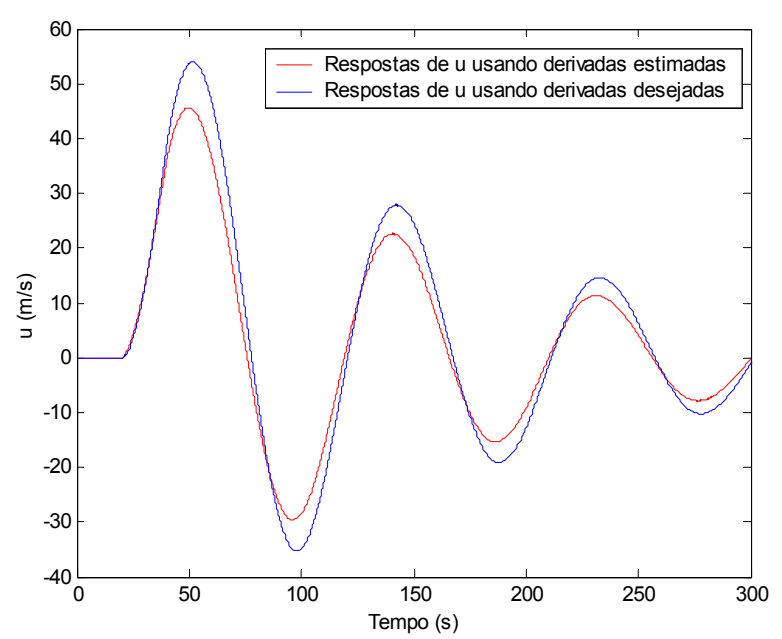

Figura 5.20. Respostas de variação de $u$ usando derivadas teóricas e estimadas para o caso1.

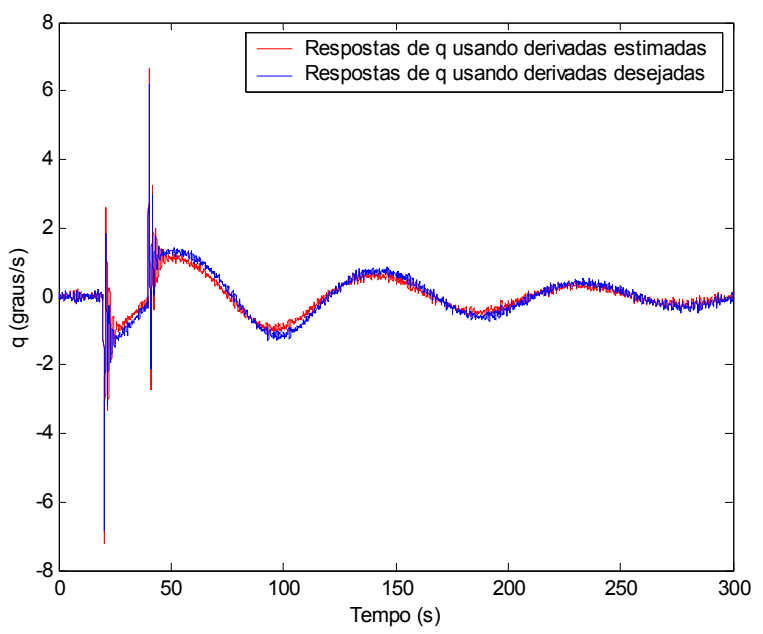

Figura 5.22. Respostas de variação de $q$ usando derivadas teóricas e estimadas para o caso 1.

Analogamente, serão mostradas as comparações de respostas da aeronave para o caso 2, usando também as respostas das derivadas estimadas no simulador e as derivadas teóricas (desejadas). Primeiramente foi usada também uma entrada pulso juntamente com ruído. Esta entrada está apresentada na Figura 5.23 e as respostas nas Figuras 5.24, 5.25 e 5.26. 


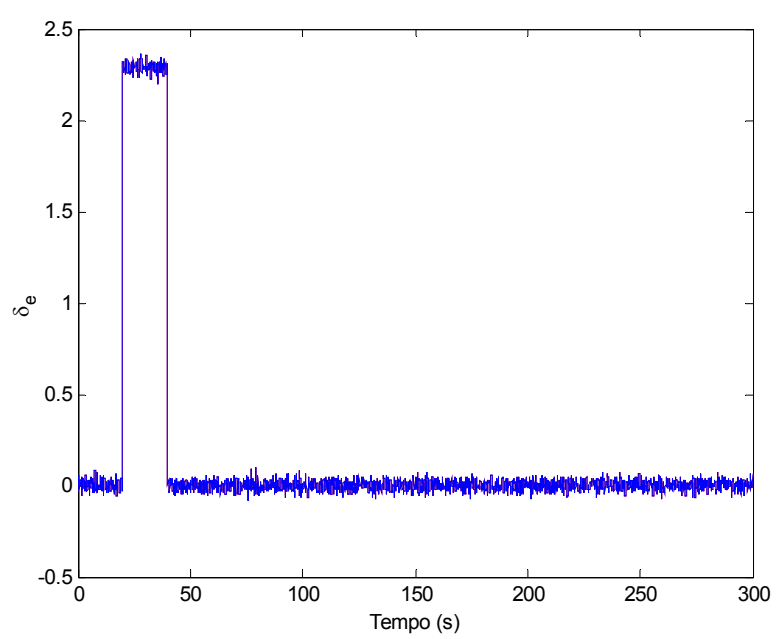

Figura 5.23. Entrada pulso juntamente com ruído usada no profundor.

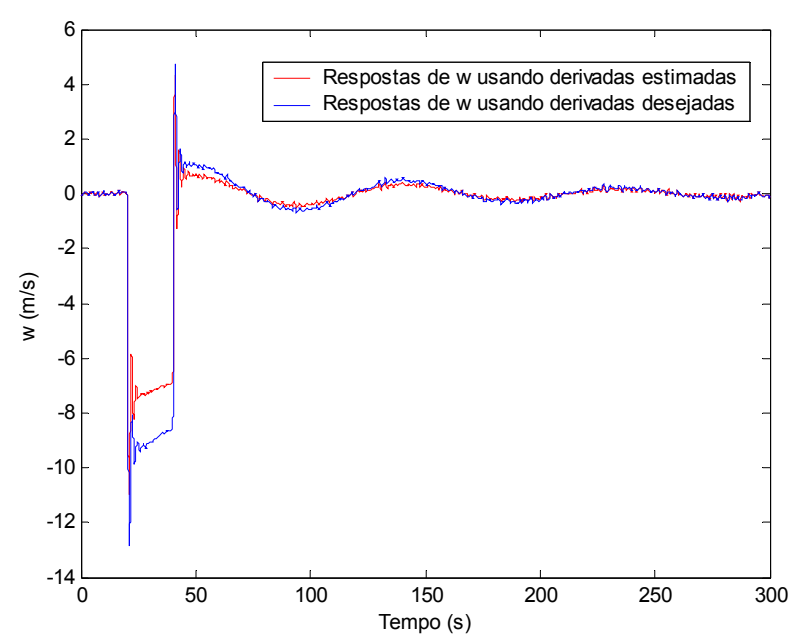

Figura 5.25. Respostas de variação de $w$ usando derivadas teóricas e estimadas para o caso 2.

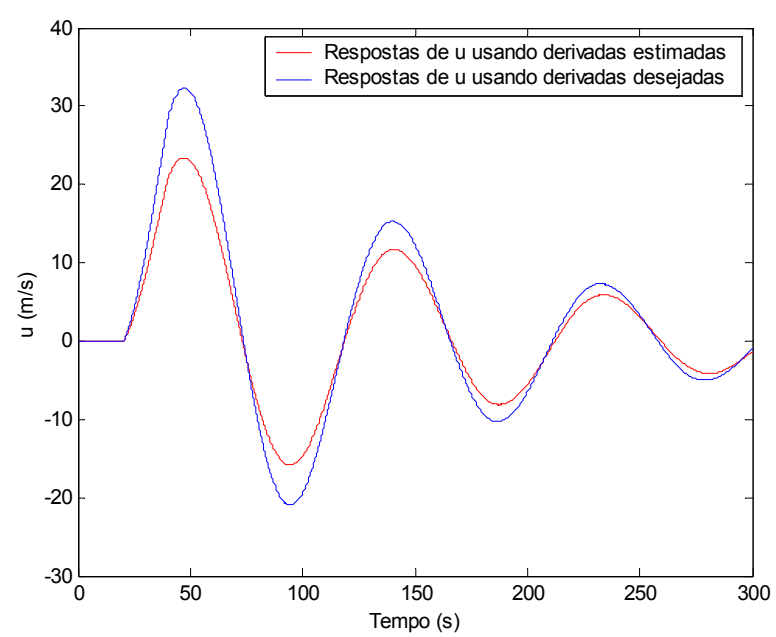

Figura 5.24. Respostas de variação de $u$ usando derivadas teóricas e estimadas para o caso2.

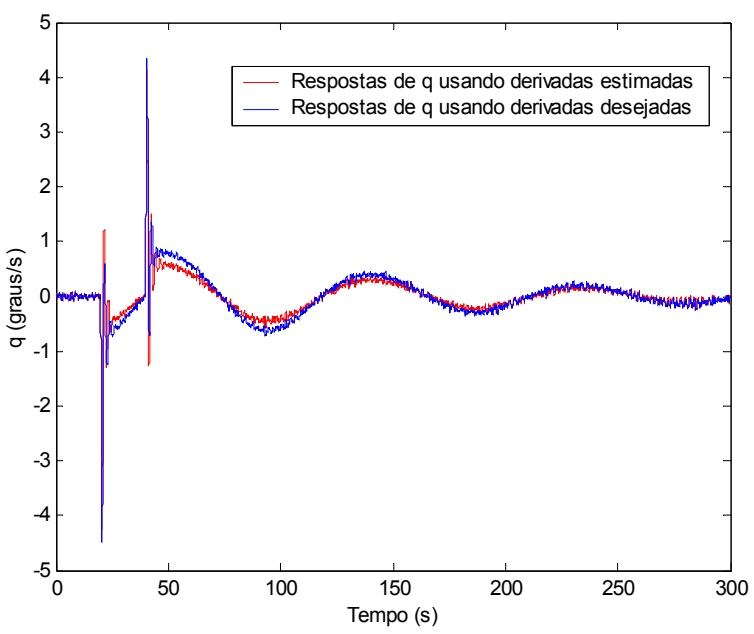

Figura 5.26. Respostas de variação de $q$ usando derivadas teóricas e estimadas para o caso 2.

Um segundo teste foi realizado para os dados referentes ao caso 2, porém usando entrada do tipo 3-2-1-1 nos profundores como mostra a Figura 5.27 a seguir. As respostas nas Figuras $5.28,5.29$ e 5.30 mostram também que as respostas da aeronave usando as derivadas estimadas e as teóricas foram bastante próximas. 


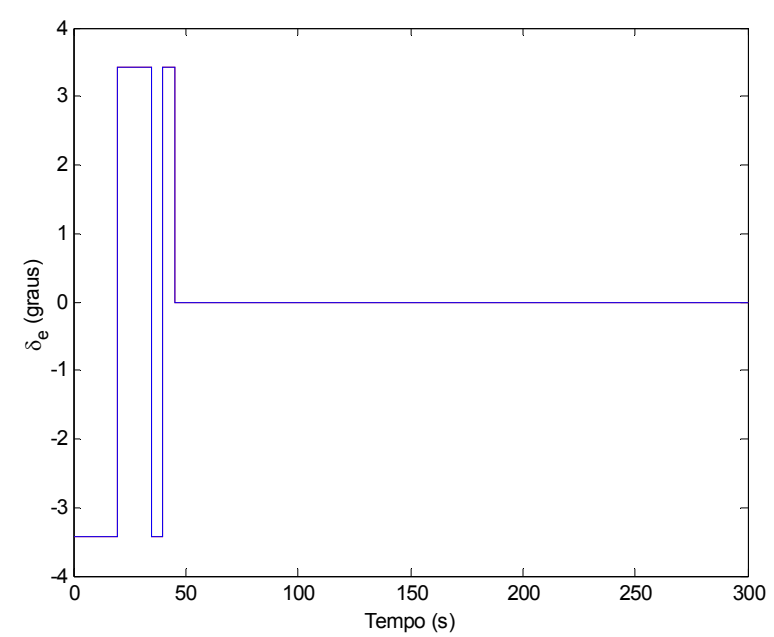

Figura 5.27. Entrada 3-2-1-1 usada no profundor.

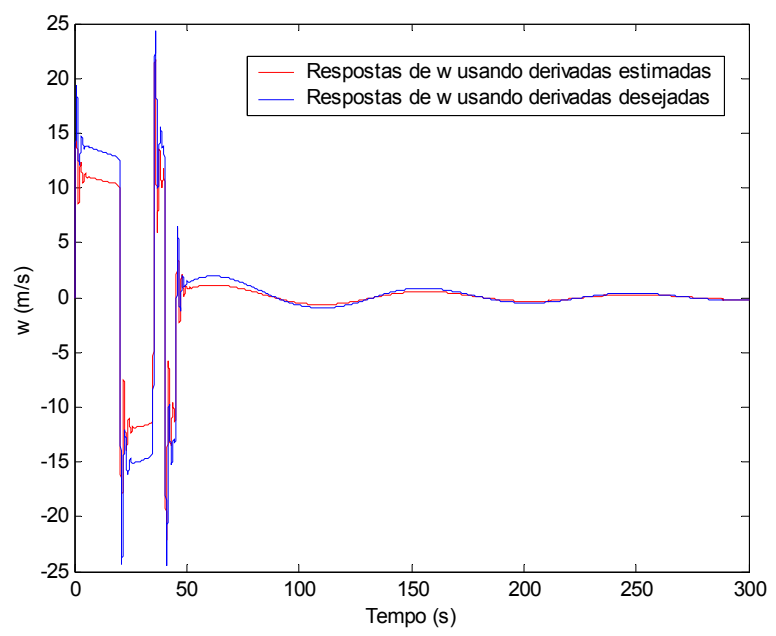

Figura 5.29. Respostas de variação de $w$ usando derivadas teóricas e estimadas para o caso 2 .

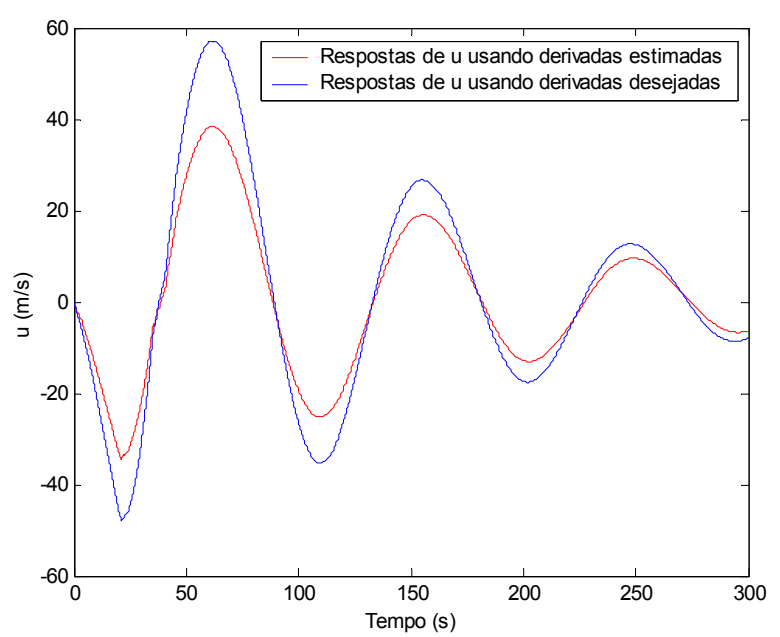

Figura 5.28. Respostas de variação de u usando derivadas teóricas e estimadas para o caso 2 .

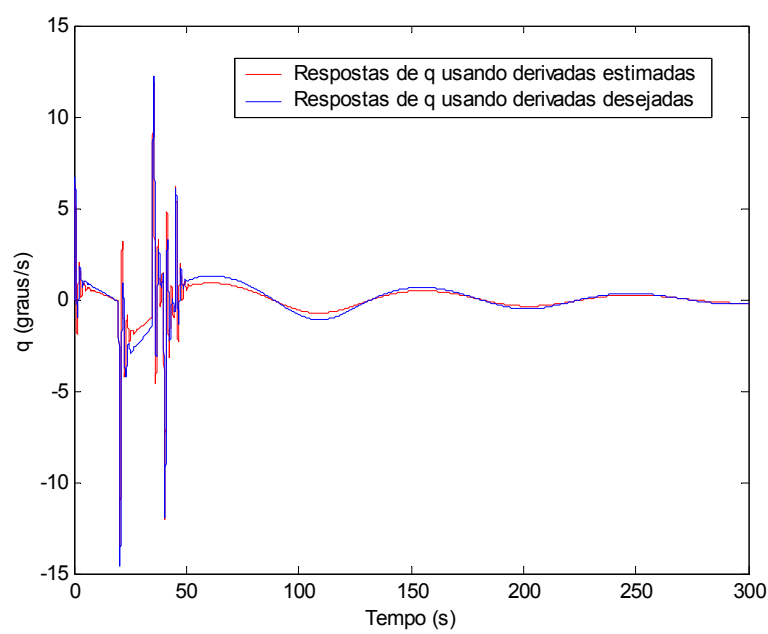

Figura 5.30. Respostas de variação de $q$ usando derivadas teóricas e estimadas para o caso 2 .

A seguir, nas Figuras 5.31, 5.32, 5.33 e 5.34 estão mostradas, respectivamente, a entrada também do tipo 3-2-1-1 usada nos profundores e as respostas das variações da velocidade horizontal $u$, vertical $w$ e de arfagem $q$ obtidas em simulação, porém usando dados do caso 3 do envelope de vôo Os resultados se mostraram bastante próximos também 

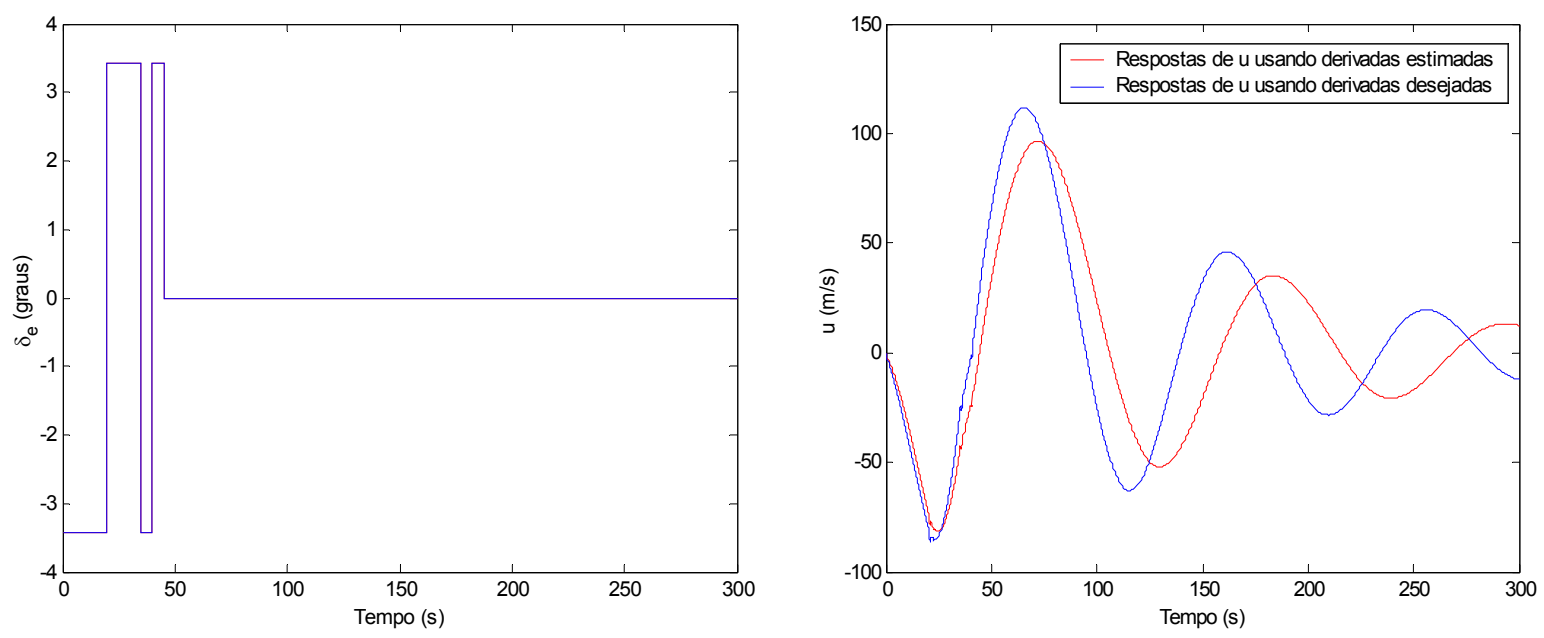

Figura 5.31. Entrada 3-2-1-1 usada no profundor. Figura 5.32. Respostas de variação de u usando derivadas teóricas e estimadas para o caso 3.

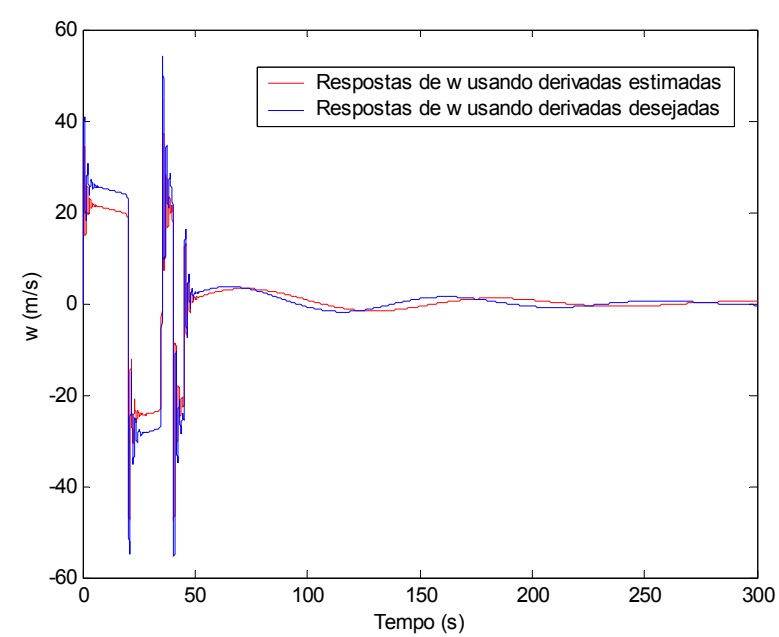

Figura 5.33. Respostas de variação de $w$ usando derivadas teóricas e estimadas para o caso 3.

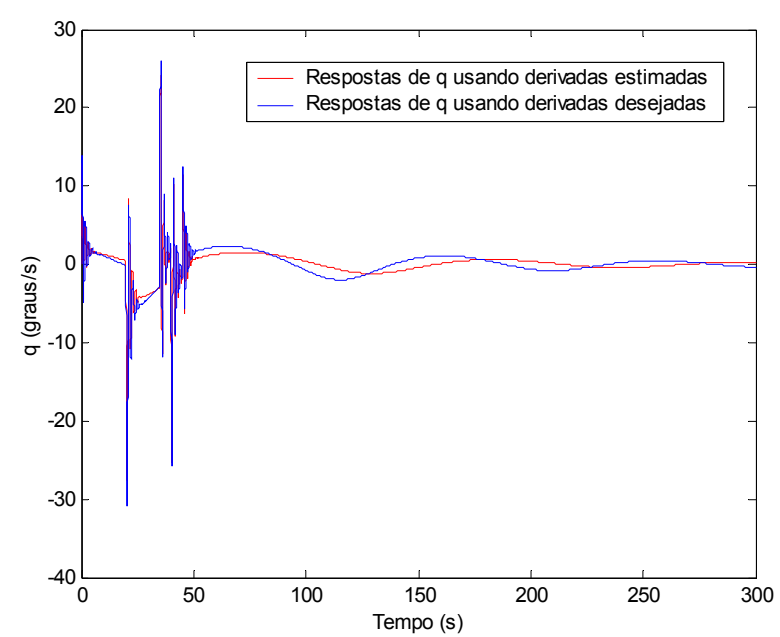

Figura 5.34. Respostas de variação de $q$ usando derivadas teóricas e estimadas para o caso 3.

As Figuras 5.35, 5.36, 5.37 e 5.38 mostram a entrada, as variações da velocidade horizontal $u$, vertical $w$ e de arfagem $q$ obtidas em simulação da aeronave com dados referentes ao caso 4. Vários outros testes foram realizados, mas não serão mostrados no texto. 


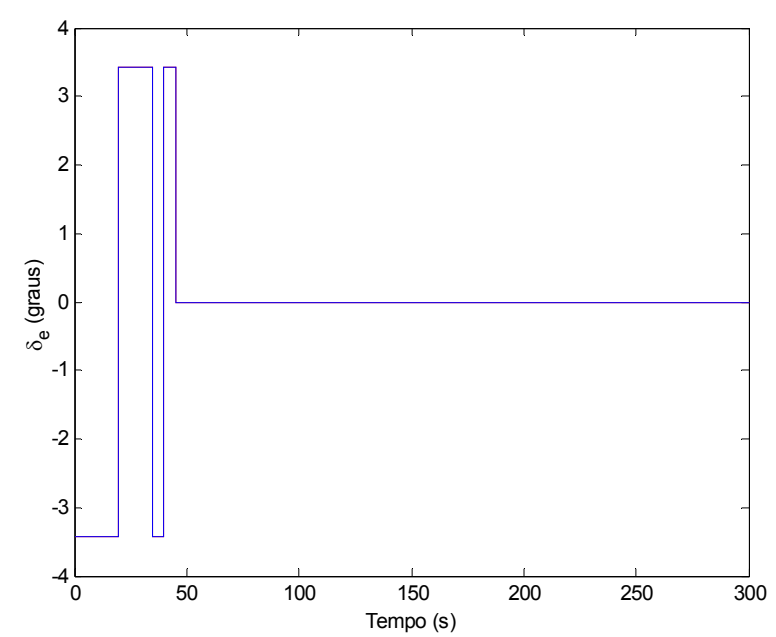

Figura 5.35. Entrada 3-2-1-1 usada no profundor.

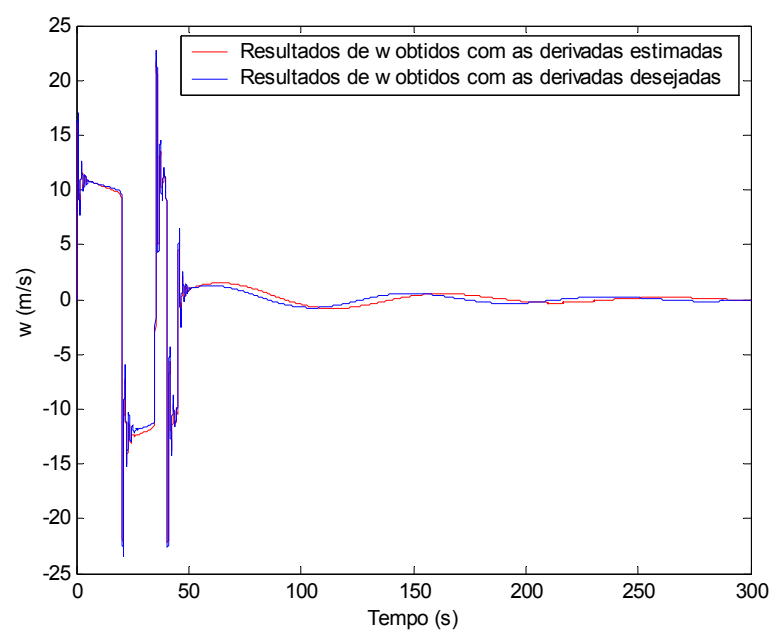

Figura 5.37. Respostas de variação de $w$ usando derivadas teóricas e estimadas para o caso 4 .

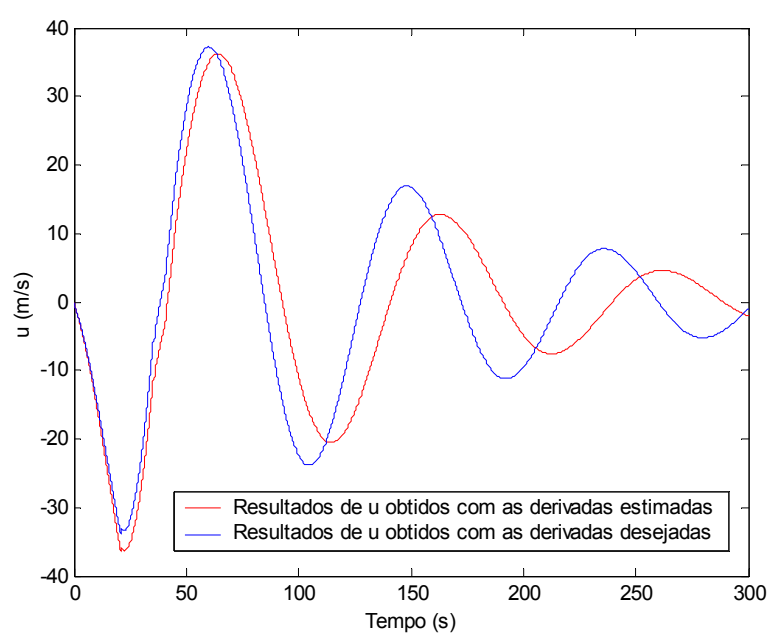

Figura 5.36. Respostas de variação de u usando derivadas teóricas e estimadas para o caso 4 .

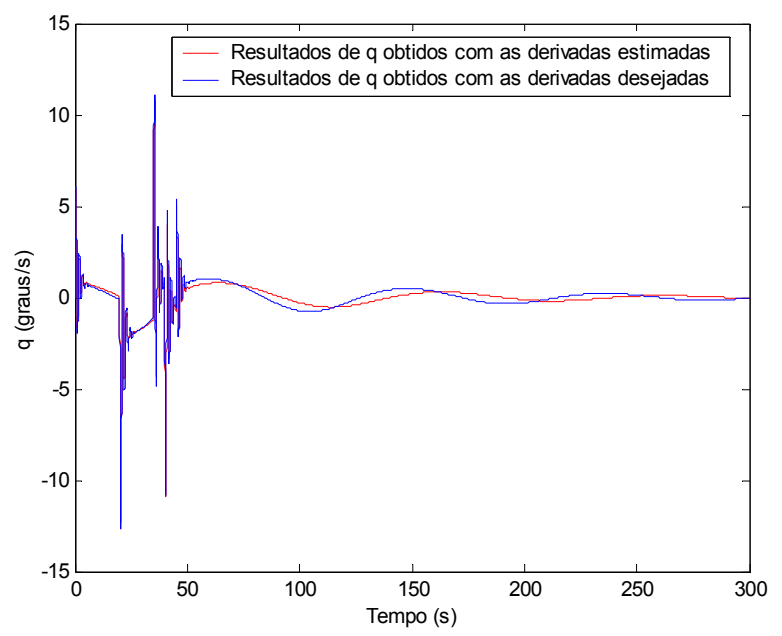

Figura 5.38. Respostas de variação de $q$ usando derivadas teóricas e estimadas para o caso 4.

Finalmente serão apresentadas comparações de resultados obtidos através de simulação realizada usando derivadas teóricas e estimadas referentes ao caso 7 do envelope de vôo. A Figura 5.39 mostra a entrada, pulso juntamente com ruído, usada para a simulação e as Figuras 5.40, 5.41 e 5.42 as variações da velocidade horizontal $u$, vertical $w$ e de arfagem $q$. Os resultados também se mostraram bastante satisfatórios, mas como em todos os apresentados anteriormente, as respostas de $u$ usando as derivadas estimadas foram as menos precisas. 


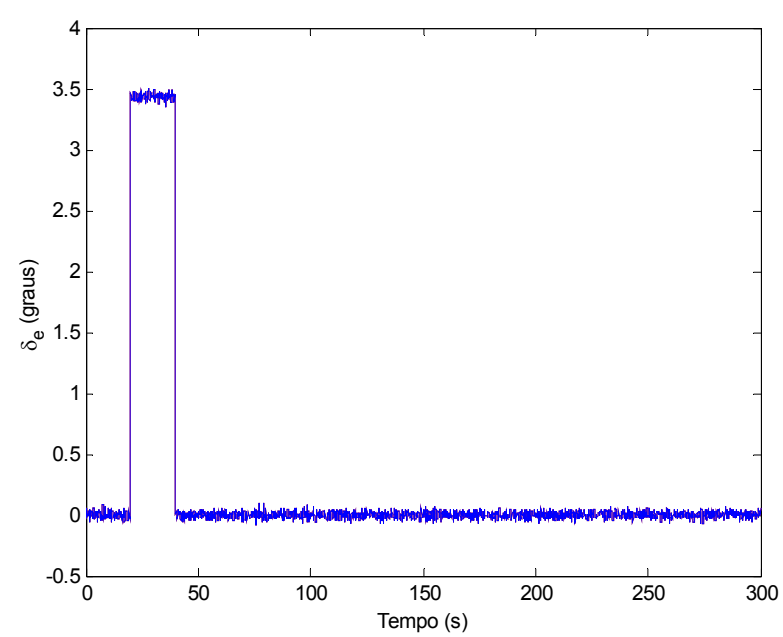

Figura 5.39. Entrada usada no profundor.

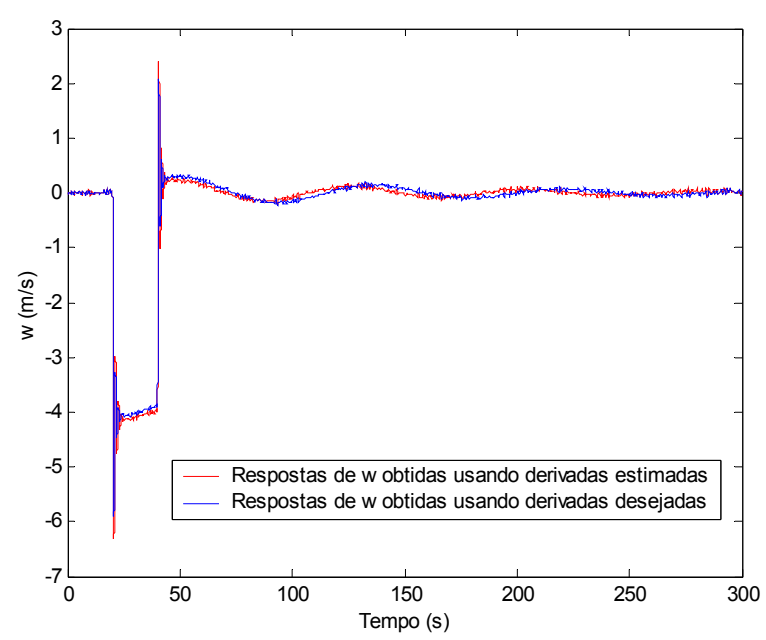

Figura 5.41. Respostas de variação de $w$ usando derivadas teóricas e estimadas para o caso 7.

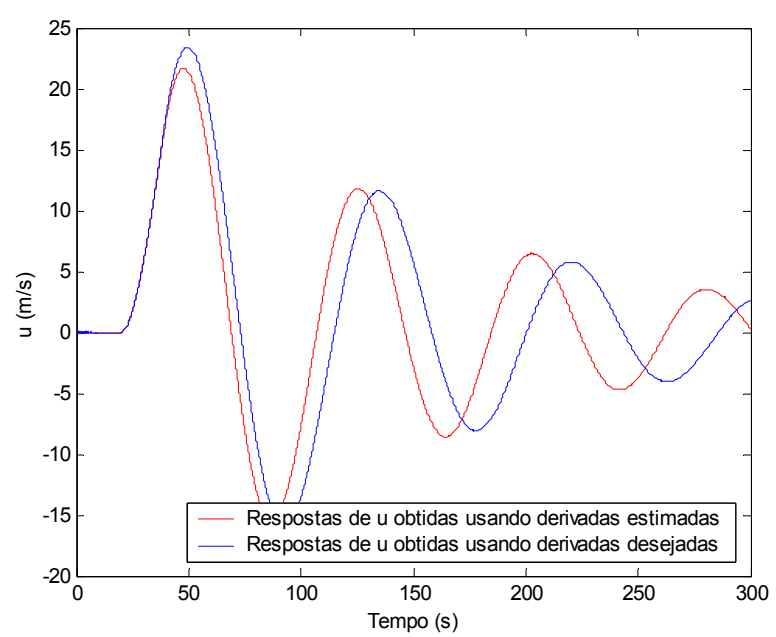

Figura 5.40. Respostas de variação de u usando derivadas teóricas e estimadas para o caso 7.

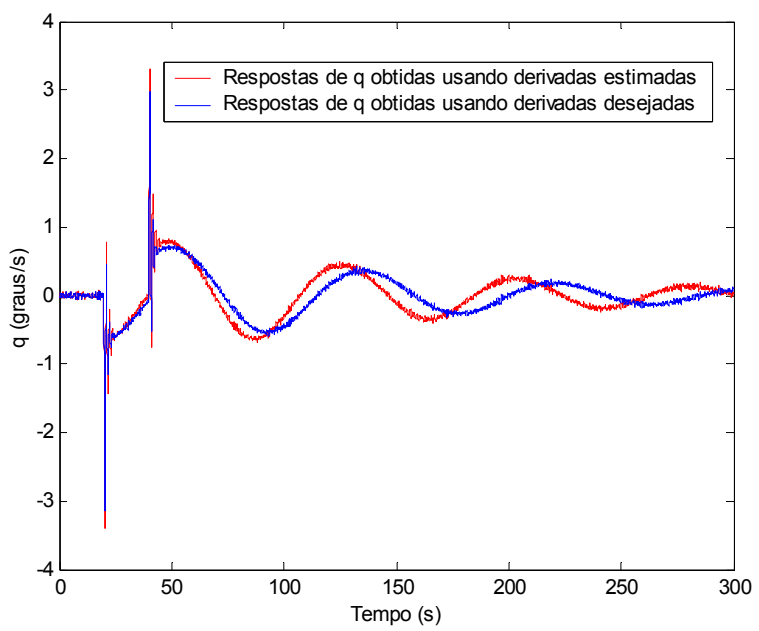

Figura 5.42. Respostas de variação de $q$ usando derivadas teóricas e estimadas para o caso 7.

De modo geral, os resultados obtidos foram satisfatórios, mas pode-se observar que a rede neural teve maior dificuldade na estimação das derivadas $X_{w}, Z_{w}$ e $M_{w}$ referentes ao caso $1, X_{w}$ e $M_{q}$ referentes ao caso $2, X_{w}, Z_{u}$ e $M_{w}$ referentes ao caso 2 e $M_{q}$ e $Z_{u}$ referentes aos casos 4 e 7. Essas diferenças puderam ser verificadas nas figuras comparativas entre respostas de simulação usando derivadas estimadas e desejadas apresentadas. Uma possível causa disto pode ser o fato da rede neural ter sido treinada com dados pobres de informação, ou seja, seria necessário outro tipo de manobra que gerasse outro conjunto de dados de entradas e saídas para treiná-la com informações mais ricas em termos de comportamento dinâmico da aeronave simulada. 


\subsection{Resultados experimentais}

Análogo ao mostrado na seção 5.4, será mostrada agora a aplicação da metodologia na estimação de derivadas aerodinâmicas de estabilidade usando dados obtidos em ensaio em vôo. Serão usados dados correspondentes a 57 condições de vôo da aeronave militar a jato AT-26 Xavante da Força Aérea Brasileira dentro de um envelope de vôo. Como, para a aplicação desta metodologia de redes neurais era necessário que se conhecessem as derivadas em alguns pontos do envelope de vôo, foram usados os dados estimados por MACIEL et al. (2007).

\subsubsection{Apresentação dos dados da aeronave Xavante AT-26 e do envelope de vôo em estudo}

MACIEL et al. (2007) aplicaram o método de estimação por Máxima Verossimilhança com algoritmo Output error a dados obtidos por sensores instalados na aeronave Xavante para estimação das derivadas de controle e de estabilidade desta em 12 pontos do envelope de vôo considerado. Deste conjunto de dados, especificamente as derivadas correspondentes a 6 pontos do envelope de vôo serão usadas para treinamento da rede neural artificial e o restante será usado para verificar a capacidade de generalização da RNA.

A Tabela 5.24 apresenta os dados inerciais e geométricos da aeronave Xavante a ser identificada e as Tabelas 5.25, 5.26 e 5.27, respectivamente, mostram as condições da aeronave no envelope de vôo cujos dados foram usados para treinamento, generalização e estimação.

\begin{tabular}{||c|c||}
\hline DADOS & VALOR \\
\hline$m_{0}[\mathrm{Kg}]$ & 4210 \\
\hline$I_{y}\left[\mathrm{Kg} \cdot \mathrm{m}^{2}\right]$ & 6500 \\
\hline $\bar{c}[\mathrm{~m}]$ & 1,9 \\
\hline$S\left[\mathrm{~m}^{2}\right]$ & 20,62 \\
\hline
\end{tabular}

Tabela 5.24. Dados da aeronave Xavante AT-26 (MACIEL et al., 2007). 


\begin{tabular}{||c|c|c||}
\hline Caso & Altitude (m) & Mach \\
\hline 10 & 9206,80 & 0,65 \\
\hline 20 & 9163,20 & 0,50 \\
\hline 30 & 9090,50 & 0,37 \\
\hline 40 & 6107,50 & 0,61 \\
\hline 50 & 6069,50 & 0,50 \\
\hline 60 & 6109,80 & 0,49 \\
\hline
\end{tabular}

Tabela 5.25. Condições da aeronave no

envelope de vôo correspondentes aos dados usados em treinamento da RNA

\begin{tabular}{||c|c|c||}
\hline Caso & Altitude (m) & Mach \\
\hline 15 & 9218,40 & 0,61 \\
\hline 25 & 9147,75 & 0,50 \\
\hline 35 & 9054,20 & 0,36 \\
\hline 45 & 6093,90 & 0,60 \\
\hline 55 & 6089,20 & 0,50 \\
\hline 65 & 6109,40 & 0,40 \\
\hline
\end{tabular}

Tabela 5.26. Condições da aeronave no envelope de vôo correspondentes aos dados usados para verificar generalização da RNA

\begin{tabular}{|c|c|c|c|c|c|c|c|c|c|c|c||}
\hline Caso & H (m) & Mach & Caso & H (m) & Mach & Caso & H (m) & Mach & Caso & H (m) & Mach \\
\hline $\mathbf{1 1}$ & 9156,3 & 0,6161 & $\mathbf{2 6}$ & 9135,6 & 0,5020 & $\mathbf{4 2}$ & 6100,3 & 0,6070 & $\mathbf{5 6}$ & 6091,8 & 0,4984 \\
\hline $\mathbf{1 2}$ & 9163,2 & 0,6153 & $\mathbf{2 7}$ & 9132,4 & 0,5015 & $\mathbf{4 3}$ & 6094,5 & 0,6041 & $\mathbf{5 7}$ & 6096,1 & 0,4973 \\
\hline $\mathbf{1 3}$ & 9175,6 & 0,6133 & $\mathbf{2 8}$ & 9131,7 & 0,5008 & $\mathbf{4 4}$ & 6098,7 & 0,6028 & $\mathbf{5 8}$ & 6100,3 & 0,4958 \\
\hline $\mathbf{1 4}$ & 9204,3 & 0,6113 & $\mathbf{2 9}$ & 9099,4 & 0,3666 & $\mathbf{4 6}$ & 6100,4 & 0,6016 & $\mathbf{5 9}$ & 6104,7 & 0,4950 \\
\hline $\mathbf{1 6}$ & 9149,1 & 0,5078 & $\mathbf{3 1}$ & 9083,7 & 0,3681 & $\mathbf{4 7}$ & 6072,4 & 0,5915 & $\mathbf{6 1}$ & 6116,3 & 0,4925 \\
\hline $\mathbf{1 7}$ & 9154,8 & 0,5057 & $\mathbf{3 3}$ & 9072,8 & 0,3701 & $\mathbf{4 8}$ & 6071,4 & 0,5905 & $\mathbf{6 2}$ & 6121,7 & 0,4920 \\
\hline $\mathbf{1 8}$ & 9160,1 & 0,5052 & $\mathbf{3 4}$ & 9062,4 & 0,3703 & $\mathbf{4 9}$ & 6066,5 & 0,5070 & $\mathbf{6 3}$ & 6130,9 & 0,4902 \\
\hline $\mathbf{1 9}$ & 9163,6 & 0,5039 & $\mathbf{3 6}$ & 9051,9 & 0,3695 & $\mathbf{5 0}$ & 6066,6 & 0,5064 & $\mathbf{6 4}$ & 6108,0 & 0,4015 \\
\hline $\mathbf{2 1}$ & 9163,6 & 0,5030 & $\mathbf{3 7}$ & 9055,1 & 0,3649 & $\mathbf{5 1}$ & 6072,2 & 0,5035 & $\mathbf{6 6}$ & 6113,4 & 0,3993 \\
\hline $\mathbf{2 2}$ & 9164,5 & 0,5027 & $\mathbf{3 8}$ & 6112,3 & 0,6084 & $\mathbf{5 2}$ & 6078,9 & 0,5020 & $\mathbf{6 7}$ & 6111,6 & 0,3995 \\
\hline $\mathbf{2 3}$ & 9155,5 & 0,5031 & $\mathbf{3 9}$ & 6113,1 & 0,6079 & $\mathbf{5 3}$ & 6083,6 & 0,5012 & $\mathbf{6 8}$ & 6107,1 & 0,4000 \\
\hline $\mathbf{2 4}$ & 9147,7 & 0,5011 & $\mathbf{4 1}$ & 6110,8 & 0,6075 & $\mathbf{5 4}$ & 6087,1 & 0,5003 & & & \\
\hline \hline
\end{tabular}

Tabela 5.27. Posições da aeronave no envelope de vôo para as quais a RNA será aplicada na estimação das derivadas de estabilidade e de controle.

Para facilitar a visualização das condições que a aeronave foi considerada, plotou-se um esquema do envelope de vôo em estudo na Figura 5.43 a seguir e destaca-se novamente que derivadas usadas durante treinamento e para verificar a generalização foram estimadas por MACIEL et al. (2007). A Figura 5.44 mostra uma ampliação de uma região no envelope comparando os valores usados em treinamento, generalização e os usados para realizar a estimação. 


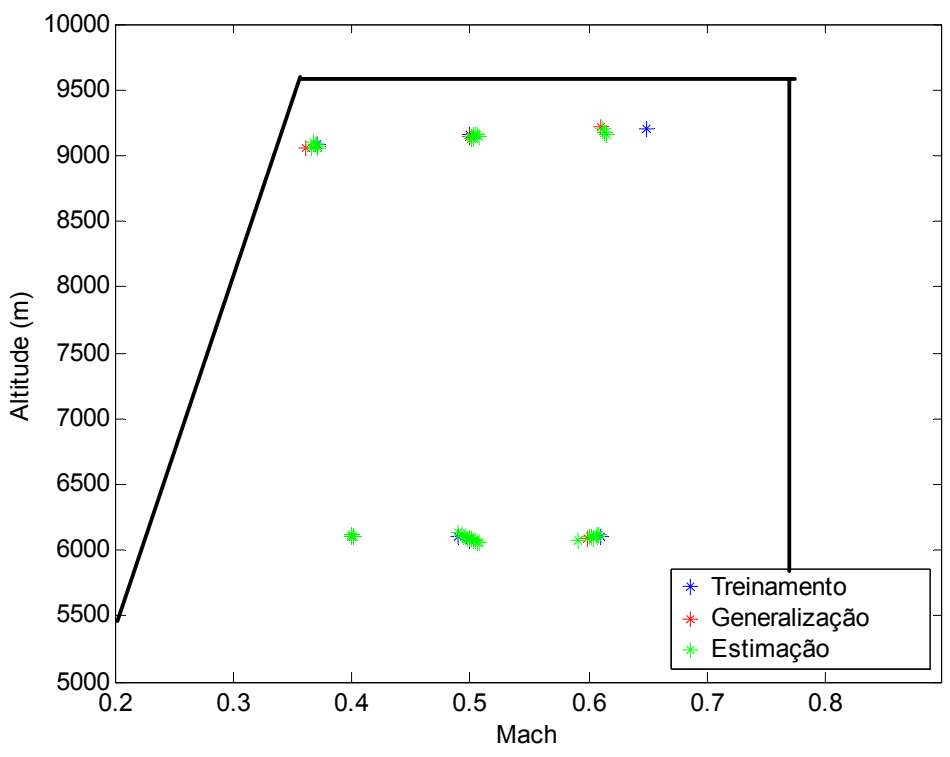

Figura 5.43 Esquema do envelope de vôo da aeronave AT-26 Xavante, mostrando os pontos nos quais foram analisadas respostas da aeronave.

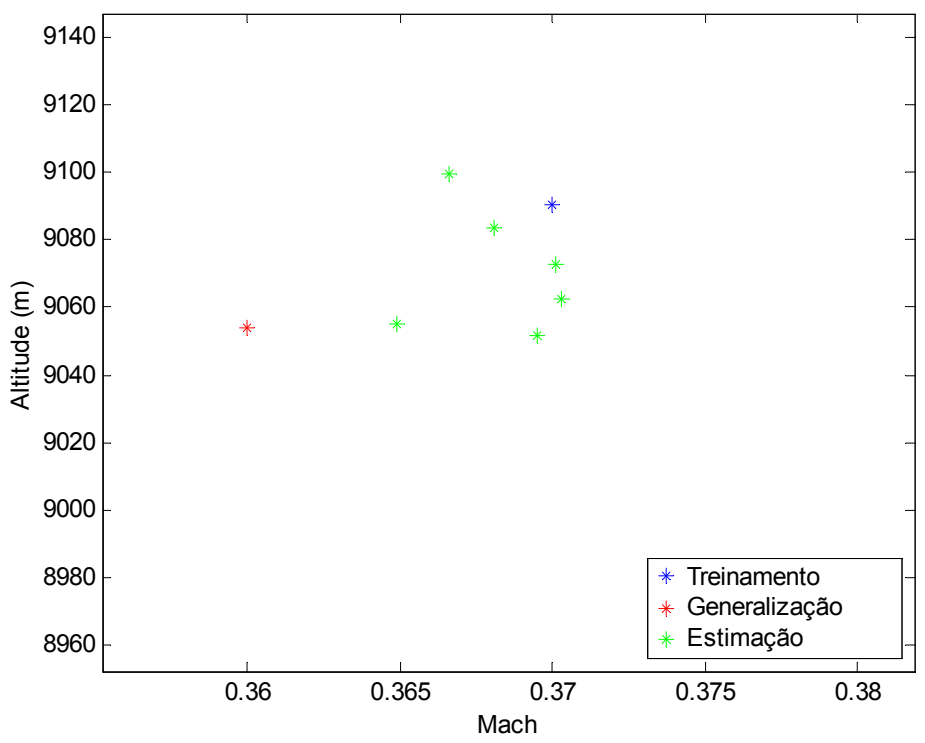

Figura 5.44. Ampliação de uma região no envelope comparando os valores usados em treinamento, generalização e os usados para realizar a estimação.

É importante ressaltar que em todos estes pontos no envelope de vôo, apenas manobras dinâmicas com excitações longitudinais no manche foram comandadas pelo piloto, visando análise apenas do movimento longitudinal da aeronave. 


\subsubsection{Estimação das derivadas aerodinâmicas usando resultados obtidos em ensaio em vôo da aeronave Xavante AT-26 dentro de um envelope de vôo via RNA's}

Como no caso apresentado na seção anterior, para a estimação das derivadas de estabilidade da aeronave simulada, será usada uma RNA feedforward, com duas camadas intermediárias de neurônios e, para treiná-la, será usado o algoritmo backpropagation.

Foram primeiramente implementadas três redes neurais distintas, uma para estimar as derivadas de estabilidade relativas a $\alpha$, outra para as derivadas relativas a $q$ e uma outra rede para estimar as derivadas de controle. Foram obtidos resultados bastante satisfatórios, mas quando se realizou um teste usando apenas uma rede neural, os resultados obtidos foram análogos. Então, foi decidido usar uma única RNA para estimar as derivadas de estabilidade e de controle e seu esquema está apresentado no diagrama de blocos da Figura 5.45.

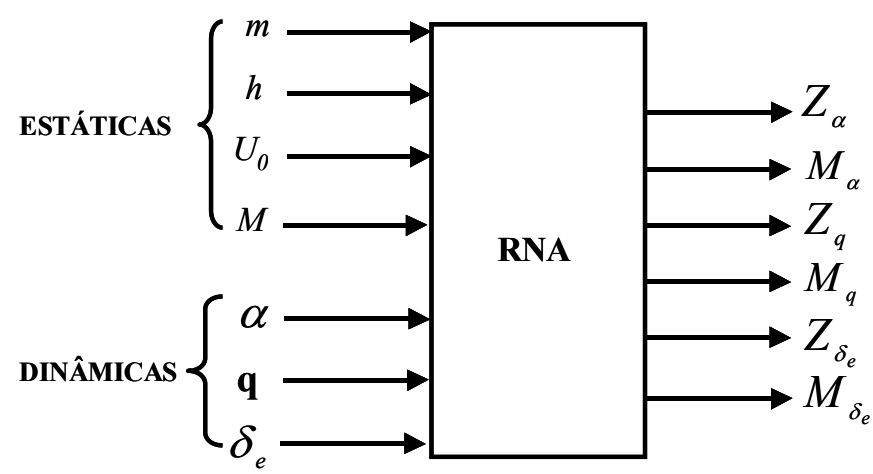

Figura 5.45. Diagrama de blocos representativo da RNA usada na estimação das derivadas aerodinâmicas de estabilidade e controle.

Como mostrado na Figura 5.45, foram usados dois tipos de entradas para a RNA: entradas estáticas que foram massa, altitude, velocidade e Mach e entradas dinâmicas que foram ângulo de ataque, velocidade de arfagem e entrada no profundor, ambos vetores com 70 pontos. Alguns vetores de respostas da aeronave possuíam um número de pontos maior que 70, mas para deixar todos com mesmo comprimento, para ser possível usar como entrada para a RNA, foram descartados. Vários testes foram realizados e a arquitetura que apresentou melhores resultados tinha 20, 18 e 6 neurônios respectivamente nas camadas intermediárias e de saída. Os resultados de treinamento estão apresentados nas Tabelas de 5.28 a 5.33. Poderá ser observado que os resultados foram bastante satisfatórios. 


\begin{tabular}{||c|c|c|c|c|c|c||}
\hline \hline$Z_{\alpha}(\mathrm{Kg} / \mathrm{s})$ & CASO 10 & CASO 20 & CASO 30 & CASO 40 & CASO 50 & CASO 60 \\
\hline Output Error & $-1,5800$ & $-1,1000$ & $-1,0100$ & $-2,3300$ & $-1,6500$ & $-1,4100$ \\
\hline RNA & $-1,5962$ & $-1,1164$ & $-1,0272$ & $-2,3484$ & $-1,6594$ & $-1,4414$ \\
\hline
\end{tabular}

Tabela 5.28. Comparação dos resultados das derivadas $Z_{w}$ teóricos e obtidos em treinamento.

\begin{tabular}{|c|c|c|c|c|c|c||}
\hline \hline$Z_{q}(\mathrm{Kg} / \mathrm{s})$ & CASO 10 & CASO 20 & CASO 30 & CASO 40 & CASO 50 & CASO 60 \\
\hline Output Error & 0,2800 & 0,2700 & 0,2200 & 0,3000 & 0,2700 & 0,2600 \\
\hline RNA & 0,2800 & 0,2697 & 0,2198 & 0,2997 & 0,2716 & 0,2585 \\
\hline
\end{tabular}

Tabela 5.29. Comparação dos resultados das derivadas $Z_{q}$ teóricos e obtidos em treinamento.

\begin{tabular}{||c|c|c|c|c|c|c||}
\hline \hline$M_{\alpha}(\mathrm{Kg} / \mathrm{s})$ & CASO 10 & CASO 20 & CASO 30 & CASO 40 & CASO 50 & CASO 60 \\
\hline Output Error & $-7,6700$ & $-4,8800$ & $-2,3000$ & $-11,6900$ & $-8,5600$ & $-8,1600$ \\
\hline RNA & $-7,7078$ & $-4,9203$ & $-2,3345$ & $-11,7204$ & $-8,6170$ & $-8,1854$ \\
\hline
\end{tabular}

Tabela 5.30. Comparação dos resultados das derivadas $M_{\alpha}$ teóricos e obtidos em treinamento.

\begin{tabular}{||c|c|c|c|c|c|c||}
\hline$M_{q}(\mathrm{Kg} / \mathrm{s})$ & CASO 10 & CASO 20 & CASO 30 & CASO 40 & CASO 50 & CASO 60 \\
\hline Output Error & $-1,8100$ & $-1,3000$ & $-0,8600$ & $-2,3100$ & $-1,8600$ & $-1,9000$ \\
\hline RNA & $-1,8133$ & $-1,3048$ & $-0,8604$ & $-2,3097$ & $-1,8814$ & $-1,8880$ \\
\hline
\end{tabular}

Tabela 5.31. Comparação dos resultados das derivadas $M_{q}$ teóricos e obtidos em treinamento.

\begin{tabular}{||c|c|c|c|c|c|c||}
\hline \hline$Z_{\delta_{e}}(\mathrm{Kg} / \mathrm{s})$ & CASO 10 & CASO 20 & CASO 30 & CASO 40 & CASO 50 & CASO 60 \\
\hline Output Error & $-0,7600$ & $-0,6400$ & $-0,5700$ & $-1,0000$ & $-0,8000$ & $-0,7200$ \\
\hline RNA & $-0,7667$ & $-0,6483$ & $-0,5763$ & $-1,0064$ & $-0,8105$ & $-0,7264$ \\
\hline
\end{tabular}

Tabela 5.32. Comparação dos resultados das derivadas $Z_{\delta_{e}}$ teóricos e obtidos em treinamento.

\begin{tabular}{|c|c|c|c|c|c|c||}
\hline \hline$M_{\delta_{e}}(\mathrm{Kg} / \mathrm{s})$ & CASO 10 & CASO 20 & CASO 30 & CASO 40 & CASO 50 & CASO 60 \\
\hline Output Error & 15,9200 & 10,6600 & 6,0400 & 20,4000 & 15,1300 & 14,5400 \\
\hline RNA & 15,8908 & 10,6011 & 5,9983 & 20,3817 & 15,0657 & 14,5026 \\
\hline
\end{tabular}

Tabela 5.33. Comparação dos resultados das derivadas $M_{\delta_{e}}$ teóricos e obtidos em treinamento. 
Análogo ao feito para o problema simulado, foi calculado o erro quadrático médio para cada conjunto de derivadas. Os resultados obtidos, respectivamente para as Tabelas 5.28 a 5.33 foram $3,710^{-4}, 5,0310^{-6}, 1,510^{-3}, 1,0610^{-4}, 5,710^{-5}$ e $210^{-3}$.

Como feito com resultados de treinamento, serão apresentados nas Tabelas de 5.34 a 5.39 comparações dos resultados das derivadas estimadas com os teóricos para os 6 casos usados em generalização, cujas altitudes e Mach correspondentes podem ser verificadas na Tabela 5.28. Os respectivos erros quadráticos médios encontrados foram $0,2,2,310^{-3}, 1,7,0,13,0,02$ e 7,8. Como pode-se observar, os valores dos erros encontrados foram bem menores que para o problema simulado.

\begin{tabular}{||c|c|c|c|c|c|c||}
\hline \hline$Z_{\alpha}(\mathrm{Kg} / \mathrm{s})$ & CASO 15 & CASO 25 & CASO 35 & CASO 45 & CASO 55 & CASO 65 \\
\hline Output Error & $-1,42$ & $-0,9700$ & $-0,9100$ & $-2,0000$ & $-1,6600$ & $-1,1300$ \\
\hline RNA & $-1,1014$ & $-1,0431$ & $-0,9989$ & $-2,3109$ & $-1,5801$ & $-1,0959$ \\
\hline
\end{tabular}

Tabela 5.34. Comparação dos resultados das derivadas $Z_{\alpha}$ teóricos e estimados pela RNA.

\begin{tabular}{||c|c|c|c|c|c|c||}
\hline$Z_{q}(\mathrm{Kg} / \mathrm{s})$ & CASO 15 & CASO 25 & CASO 35 & CASO 45 & CASO 55 & CASO 65 \\
\hline Output Error & 0,3000 & 0,2000 & 0,2700 & 0,2900 & 0,2300 & 0,1900 \\
\hline RNA & 0,2680 & 0,2656 & 0,2277 & 0,3031 & 0,2652 & 0,2607 \\
\hline
\end{tabular}

Tabela 5.35. Comparação dos resultados das derivadas $Z_{q}$ teóricos e estimados pela RNA.

\begin{tabular}{||c|c|c|c|c|c|c||}
\hline \hline$M_{\alpha}(\mathrm{Kg} / \mathrm{s})$ & CASO 15 & CASO 25 & CASO 35 & CASO 45 & CASO 55 & CASO 65 \\
\hline Output Error & $-7,2800$ & $-5,0100$ & $-2,3000$ & $-11,9300$ & $-8,6500$ & $-5,4500$ \\
\hline RNA & $-4,6904$ & $-3,2805$ & $-2,2546$ & $-11,5980$ & $-8,5230$ & $-4,5372$ \\
\hline
\end{tabular}

Tabela 5.36. Comparação dos resultados das derivadas $M_{\alpha}$ teóricos e estimados pela RNA.

\begin{tabular}{||c|c|c|c|c|c|c||}
\hline$M_{q}(\mathrm{Kg} / \mathrm{s})$ & CASO 15 & CASO 25 & CASO 35 & CASO 45 & CASO 55 & CASO 65 \\
\hline Output Error & $-1,6200$ & $-1,3800$ & $-0,9500$ & $-2,3700$ & $-1,7500$ & $-1,6900$ \\
\hline RNA & $-1,2182$ & $-0,8883$ & $-0,8305$ & $-2,2838$ & $-1,8826$ & $-1,1058$ \\
\hline
\end{tabular}

Tabela 5.37. Comparação dos resultados das derivadas $M_{q}$ teóricos e estimados pela RNA. 


\begin{tabular}{||c|c|c|c|c|c|c||}
\hline$Z_{\delta_{e}}(\mathrm{Kg} / \mathrm{s})$ & CASO 15 & CASO 25 & CASO 35 & CASO 45 & CASO 55 & CASO 65 \\
\hline Output Error & $-0,9500$ & $-0,7100$ & $-0,4900$ & $-1,1300$ & $-0,7800$ & $-0,6800$ \\
\hline RNA & $-0,6501$ & $-0,6396$ & $-0,5679$ & $-1,0156$ & $-0,7831$ & $-0,6451$ \\
\hline
\end{tabular}

Tabela 5.38. Comparação dos resultados das derivadas $Z_{\delta_{e}}$ teóricos e estimados pela RNA.

\begin{tabular}{||c|c|c|c|c|c|c||}
\hline$M_{\delta_{e}}(\mathrm{Kg} / \mathrm{s})$ & CASO 15 & CASO 25 & CASO 35 & CASO 45 & CASO 55 & CASO 65 \\
\hline Output Error & 14,3300 & 11,0700 & 6,0400 & 19,7900 & 14,4600 & 10,9300 \\
\hline RNA & 9,8000 & 6,6216 & 5,1327 & 20,2997 & 14,7762 & 8,5854 \\
\hline
\end{tabular}

Tabela 5.39. Comparação dos resultados das derivadas $M_{\delta_{e}}$ teóricos e estimados pela RNA.

Visando verificar a precisão das derivadas de estabilidade e de controle estimadas, foram simuladas respostas da aeronave usando dados correspondentes aos casos 25 e 55 do envelope de vôo. Outros casos também foram simulados e apresentaram bons resultados, mas não serão apresentados nesta Tese para não deixar o texto extenso. Para simular as respostas da aeronave, foi usado o modelo apresentado por MACIEL et al. (2007). A Figuras 5.46 e 5.47 apresentam a entrada usada no profundor (dp), comparação das variações reais e simuladas usando as derivadas estimadas de ângulo de ataque $\alpha$, velocidade de arfagem $\mathrm{q}$ e da aceleração vertical $\mathrm{a}_{\mathrm{z}}$ correspondentes aos casos 25 e 45 do envelope de vôo.
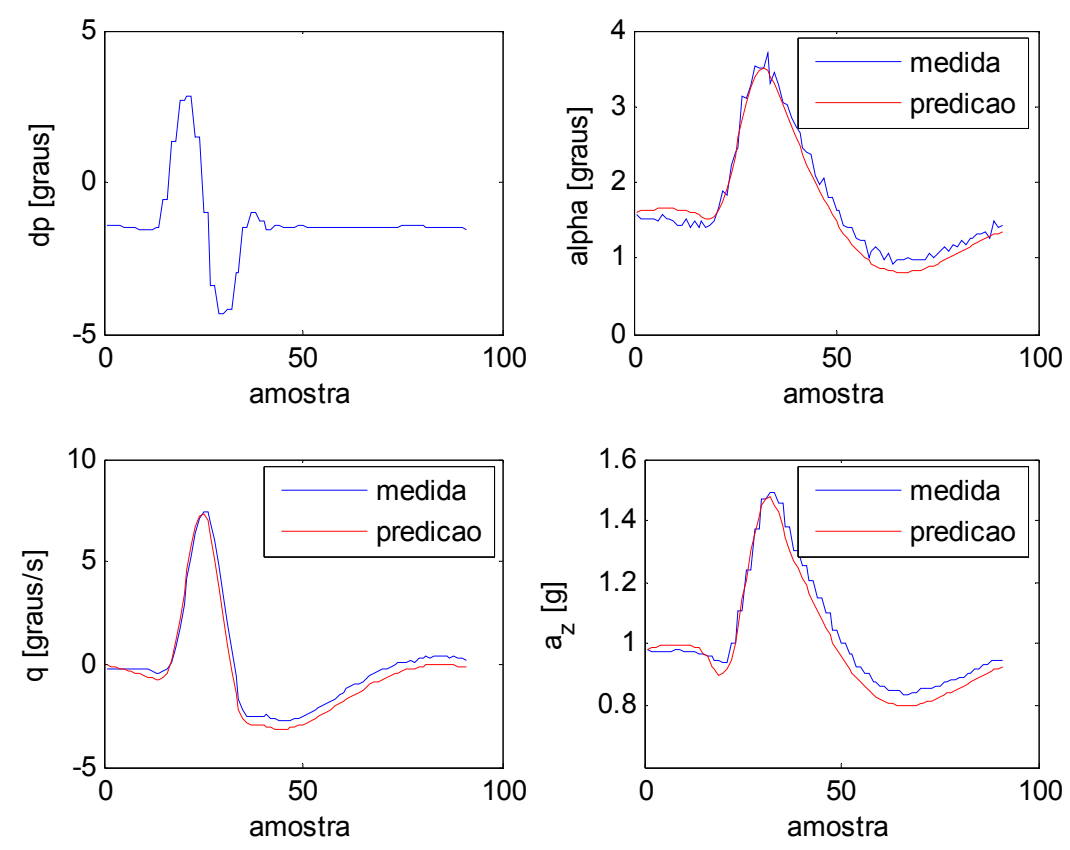

Figura 5.46. Entrada de profundor e gráficos comparativos de respostas obtidas em ensaio em vôo e simuladas usando derivadas estimadas pela RNA correspondentes ao caso 25 do envelope. 

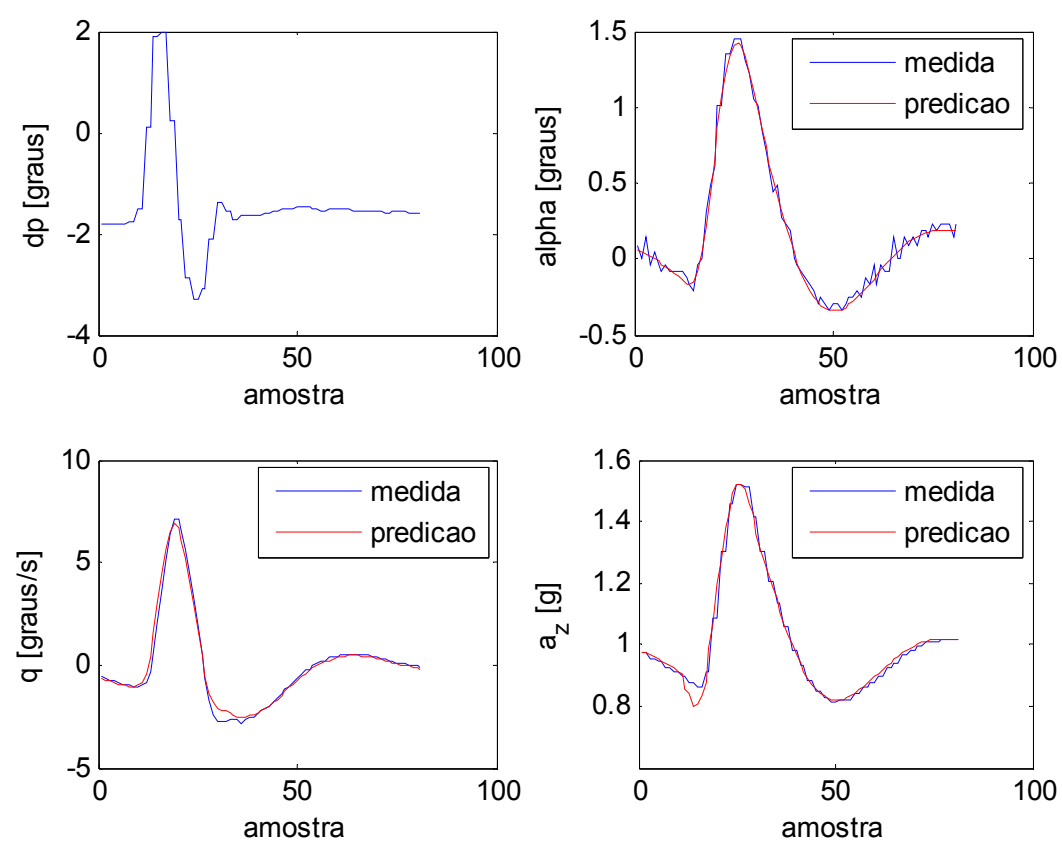

Figura 5.47. Entrada de profundor e gráficos comparativos de respostas obtidas em ensaio em vôo e simuladas usando derivadas estimadas pela RNA correspondentes ao caso 45 do envelope.

Após verificação da generalização da RNA, esta foi usada para estimar as derivadas de estabilidade e de controle nos outros pontos do envelope de vôo, onde estas não são conhecidas. Os resultados estão apresentados nas Tabelas 5.40, 5.41, 5.42 e 5.43.

\begin{tabular}{||l|l|l|l|l|l|c||}
\hline Caso & \multicolumn{1}{|c|}{$Z_{\alpha}$} & $Z_{q}$ & $M_{\alpha}$ & $M_{q}$ & $Z_{\delta_{e}}$ & $M_{\delta_{e}}$ \\
\hline $\mathbf{1 1}$ & -1.8229 & 0.2715 & $-8,5412$ & $-1,193$ & $-0,8636$ & 14,5209 \\
\hline $\mathbf{1 2}$ & -1.7412 & 0.2776 & $-8,7804$ & $-0,7917$ & $-0,8391$ & 15,4029 \\
\hline $\mathbf{1 3}$ & -1.3392 & 0.2557 & $-5,2546$ & $-0,6824$ & $-0,8141$ & 7,2760 \\
\hline $\mathbf{1 4}$ & -1.6944 & 0.2399 & $-9,7244$ & $-1,8737$ & $-0,9119$ & 12,1295 \\
\hline $\mathbf{1 6}$ & -1.4670 & 0.2593 & $-6,7746$ & $-0,6610$ & $-0,8350$ & 9,2683 \\
\hline $\mathbf{1 7}$ & -1.1611 & 0.2279 & $-0,6033$ & $-1,7700$ & $-0,7441$ & 6,2536 \\
\hline $\mathbf{1 8}$ & -1.0962 & 0.2521 & $-2,6509$ & $-0,6937$ & $-0,6916$ & 5,0179 \\
\hline $\mathbf{1 9}$ & -1.7378 & 0.2720 & $-8,7353$ & $-0,9174$ & $-0,8614$ & 14,6875 \\
\hline $\mathbf{2 1}$ & -1.0020 & 0.2575 & $-1,5053$ & $-0,7721$ & $-0,6301$ & 4,4032 \\
\hline $\mathbf{2 2}$ & -1.2950 & 0.2562 & $-7,3935$ & $-0,7123$ & $-0,6897$ & 13,8744 \\
\hline $\mathbf{2 3}$ & -1.0533 & 0.2473 & $-1,7514$ & $-1,7703$ & $-0,6175$ & 3,8270 \\
\hline $\mathbf{2 4}$ & -1.0440 & 0.2605 & $-3,5330$ & $-0,8050$ & $-0,6194$ & 6,9180 \\
\hline
\end{tabular}

Tabela 5.40. Derivadas aerodinâmicas estimadas pela RNA para os casos de 11 ao 24 . 


\begin{tabular}{||c|l|l|l|l|l|c||}
\hline Caso & $Z_{\alpha}$ & $Z_{q}$ & $M_{\alpha}$ & $M_{q}$ & $Z_{\delta_{e}}$ & $M_{\delta_{e}}$ \\
\hline $\mathbf{2 6}$ & -0.9966 & 0.2513 & $-2,3065$ & $-1,9859$ & $-0,5898$ & 4,9303 \\
\hline $\mathbf{2 7}$ & -1.1955 & 0.2336 & $-0,7330$ & $-1,8746$ & $-0,7689$ & 4,7747 \\
\hline $\mathbf{2 8}$ & -1.1562 & 0.3747 & $-1,6450$ & $-0,9829$ & $-0,4572$ & 19,2923 \\
\hline $\mathbf{2 9}$ & -0.9959 & 0.2389 & $-2,2740$ & $-1,5419$ & $-0,5864$ & 5,2897 \\
\hline $\mathbf{3 1}$ & -1.4117 & 0.3808 & $-3,2381$ & $-1,5483$ & $-0,4924$ & 21,0097 \\
\hline $\mathbf{3 3}$ & -0.9911 & 0.2627 & $-3,0584$ & $-0,8751$ & $-0,6056$ & 6,5892 \\
\hline $\mathbf{3 4}$ & -1.0151 & 0.2568 & $-3,2989$ & $-0,8832$ & $-0,6015$ & 6,5659 \\
\hline $\mathbf{3 6}$ & -0.9865 & 0.2606 & $-2,8749$ & $-0,8466$ & $-0,6027$ & 6,2396 \\
\hline $\mathbf{3 7}$ & -2.2944 & 0.3243 & $-9,3302$ & $-2,0161$ & $-1,0249$ & 17,9690 \\
\hline $\mathbf{3 8}$ & -2.2018 & 0.2991 & $-13,3150$ & $-2,4855$ & $-0,9751$ & 23,6813 \\
\hline $\mathbf{3 9}$ & -2.3107 & 0.3018 & $-11,1984$ & $-2,2432$ & $-1,0126$ & 19,5370 \\
\hline $\mathbf{4 1}$ & -2.3703 & 0.2978 & $-12,1236$ & $-2,3616$ & $-0,9985$ & 21,0618 \\
\hline \hline
\end{tabular}

Tabela 5.41. Derivadas aerodinâmicas estimadas pela RNA Para os casos de 26 ao 41 .

\begin{tabular}{||l|l|l|l|l|l|c||}
\hline Caso & \multicolumn{1}{|c|}{$Z_{\alpha}$} & $Z_{q}$ & $M_{\alpha}$ & $M_{q}$ & $Z_{\delta_{e}}$ & $M_{\delta_{e}}$ \\
\hline $\mathbf{4 2}$ & -2.0432 & 0.3238 & $-11,8616$ & $-2,2324$ & $-1,0219$ & 22,1581 \\
\hline $\mathbf{4 3}$ & -1.6938 & 0.3089 & $-12,9332$ & $-2,5076$ & $-0,8991$ & 25,3424 \\
\hline $\mathbf{4 4}$ & -1.7741 & 0.3089 & $-13,0799$ & $-2,4881$ & $-0,9304$ & 24,9391 \\
\hline $\mathbf{4 6}$ & -2.1225 & 0.2742 & $-13,1424$ & $-2,6505$ & $-0,7314$ & 25,4456 \\
\hline $\mathbf{4 7}$ & -2.2430 & 0.2994 & $-10,4450$ & $-2,1653$ & $-0,9980$ & 18,2342 \\
\hline $\mathbf{4 8}$ & -1.7379 & 0.2670 & $-8,8190$ & $-1,9012$ & $-0,8501$ & 14,5774 \\
\hline $\mathbf{4 9}$ & -1.5534 & 0.2641 & $-8,3937$ & $-1,8897$ & $-0,7714$ & 14,6678 \\
\hline $\mathbf{5 0}$ & -1.6054 & 0.2677 & $-8,5395$ & $-1,8825$ & $-0,7914$ & 14,8856 \\
\hline $\mathbf{5 1}$ & -1.6871 & 0.2747 & $-8,6484$ & $-1,8818$ & $-0,8200$ & 15,2369 \\
\hline $\mathbf{5 2}$ & -1.6573 & 0.2636 & $-8,7249$ & $-1,8964$ & $-0,8172$ & 14,5613 \\
\hline $\mathbf{5 3}$ & -1.6388 & 0.2605 & $-8,8864$ & $-1,8737$ & $-0,8144$ & 14,5492 \\
\hline $\mathbf{5 4}$ & -1.5203 & 0.2623 & $-8,3356$ & $-1,8898$ & $-0,7587$ & 14,6037 \\
\hline
\end{tabular}

Tabela 5.42. Derivadas aerodinâmicas estimadas pela RNA para os casos de 42 ao 54 . 


\begin{tabular}{||l|l|l|l|l|l|c||}
\hline Caso & $Z_{\alpha}$ & $Z_{q}$ & $M_{\alpha}$ & $M_{q}$ & $Z_{\delta_{e}}$ & $M_{\delta_{e}}$ \\
\hline $\mathbf{5 6}$ & -1.6258 & 0.2690 & $-8,5741$ & $-1,8825$ & $-0,7988$ & 14,9467 \\
\hline $\mathbf{5 7}$ & -1.6635 & 0.2653 & $-8,6105$ & $-1,9035$ & $-0,8193$ & 14,5362 \\
\hline $\mathbf{5 8}$ & -1.6147 & 0.2618 & $-5,6998$ & $-1,2275$ & $-0,8480$ & 7,3736 \\
\hline $\mathbf{5 9}$ & -1.9934 & 0.1464 & $-5,9257$ & $-1,1001$ & $-0,3161$ & 2,9751 \\
\hline $\mathbf{6 1}$ & -1.5473 & 0.2493 & $-8,5722$ & $-1,8879$ & $-0,7801$ & 13,7416 \\
\hline $\mathbf{6 2}$ & -1.3536 & 0.2434 & $-3,9921$ & $-0,8613$ & $-0,6966$ & 4,1524 \\
\hline $\mathbf{6 3}$ & -1.1462 & 0.2734 & $-5,3784$ & $-1,4938$ & $-0,6394$ & 12,3345 \\
\hline $\mathbf{6 4}$ & -1.1362 & 0.2456 & $-7,8866$ & $-1,8580$ & $-0,6018$ & 14,8302 \\
\hline $\mathbf{6 6}$ & -1.2360 & 0.2629 & $-6,6407$ & $-1,6717$ & $-0,6688$ & 13,4092 \\
\hline $\mathbf{6 7}$ & -1.0664 & 0.2739 & $-4,7023$ & $-1,3325$ & $-0,6192$ & 11,1671 \\
\hline $\mathbf{6 8}$ & -1.0175 & 0.2693 & $-3,8798$ & $-1,0656$ & $-0,6205$ & 8,6535 \\
\hline
\end{tabular}

Tabela 5.43. Derivadas aerodinâmicas estimadas pela RNA para os casos de 56 ao 68 .

Entre estas derivadas estimadas, foram escolhidos aleatoriamente alguns conjuntos para realizar a simulação e comparação com as respostas estimadas pelo método Output Error. A Figura 5.48 apresenta os resultados obtidos com as derivadas correspondentes ao caso 34 do envelope de vôo e a Figura 5.49 os resultados correspondentes ao caso 11 do envelope. Entre todos os casos analisados do envelope de vôo, o caso 34 foi o único no qual a aeronave sofreu uma entrada de profundor bastante distinta. 

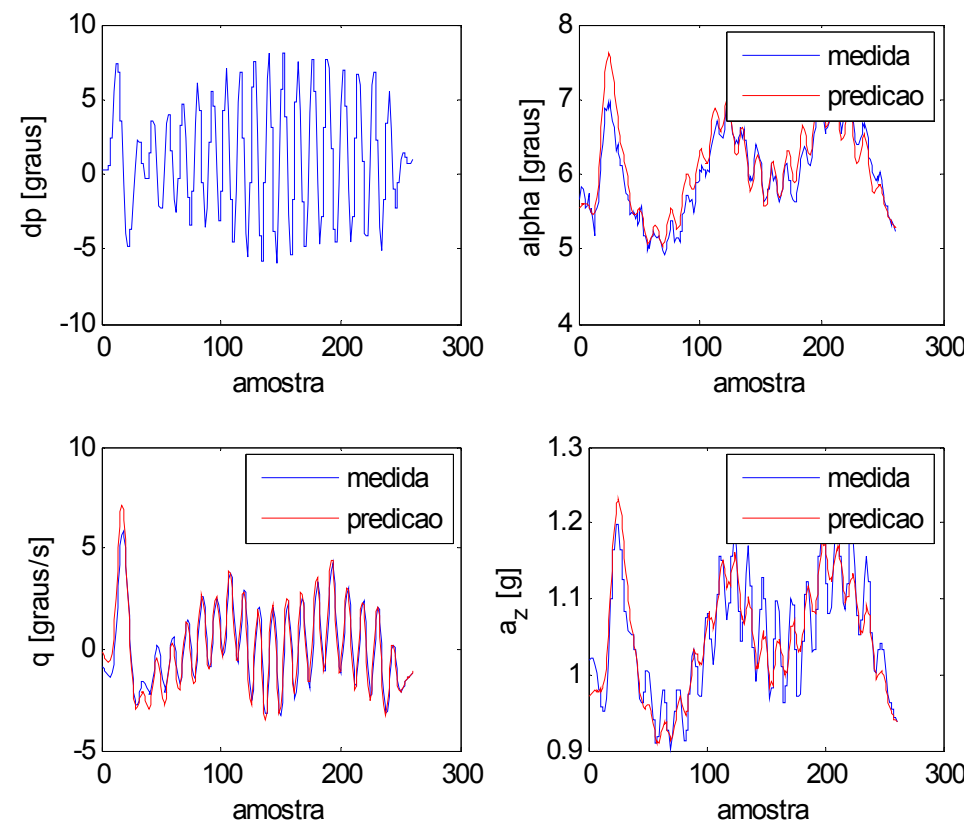

Figura 5.48. Entrada de profundor e gráficos comparativos de respostas obtidas em ensaio em vôo e simuladas usando derivadas estimadas pela RNA correspondentes ao caso 34 do envelope de vôo.
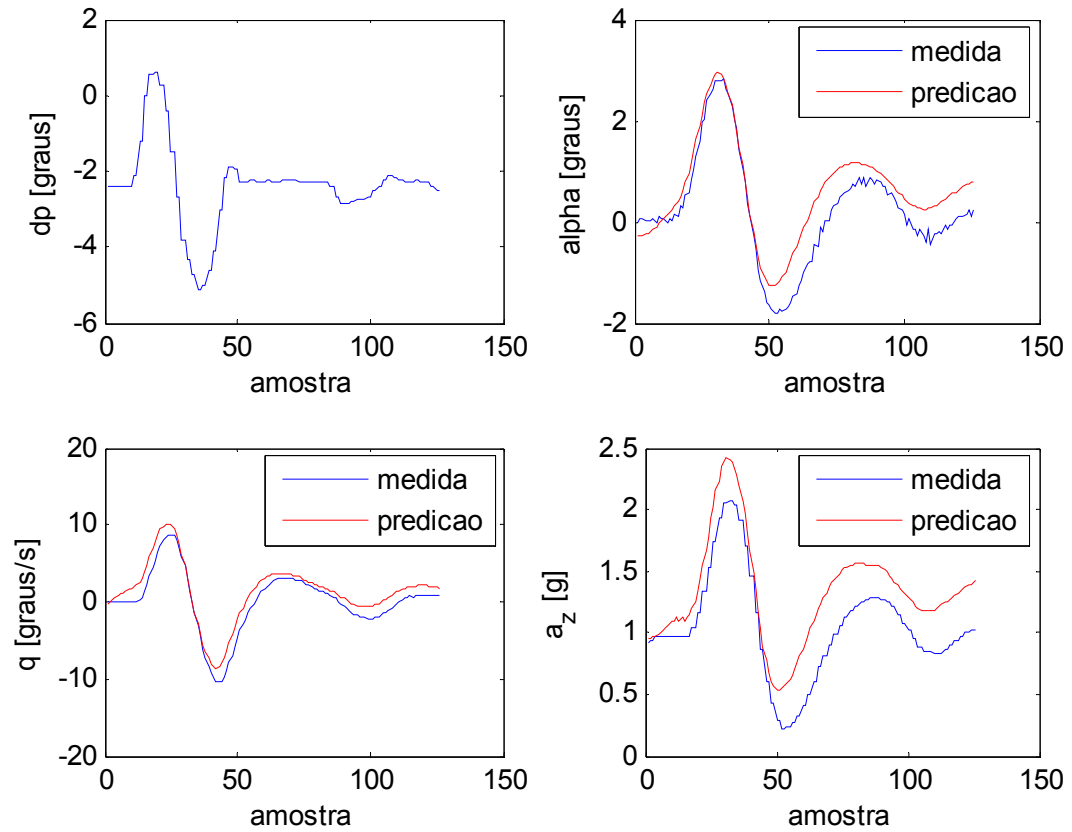

Figura 5.49. Entrada de profundor e gráficos comparativos de respostas obtidas em ensaio em vôo e simuladas usando derivadas estimadas pela RNA correspondentes ao caso 11 do envelope de vôo. 
Alguns resultados de casos escolhidos aleatoriamente serão apresentados a seguir. Por exemplo, as Figuras 5.50 e 5.51 apresentam os resultados obtidos com as derivadas correspondentes aos casos 12 e 16 do envelope de vôo respectivamente. Nas comparações de respostas simuladas e reais referentes ao caso 16 do envelope de vôo, verificou-se que as derivadas estimadas não foram satisfatórias. Isto ocorreu devido ao fato de que os vetores de estados, usados como entradas para a RNA possuíam 156 pontos e foram usados apenas 70. Ou seja, os sinais usados como entradas para a RNA não ficaram devidamente caracterizados. Em todos os outros casos houve análise dos sinais, fazendo com que as respostas fossem bastante satisfatórias como poderá ser observado.
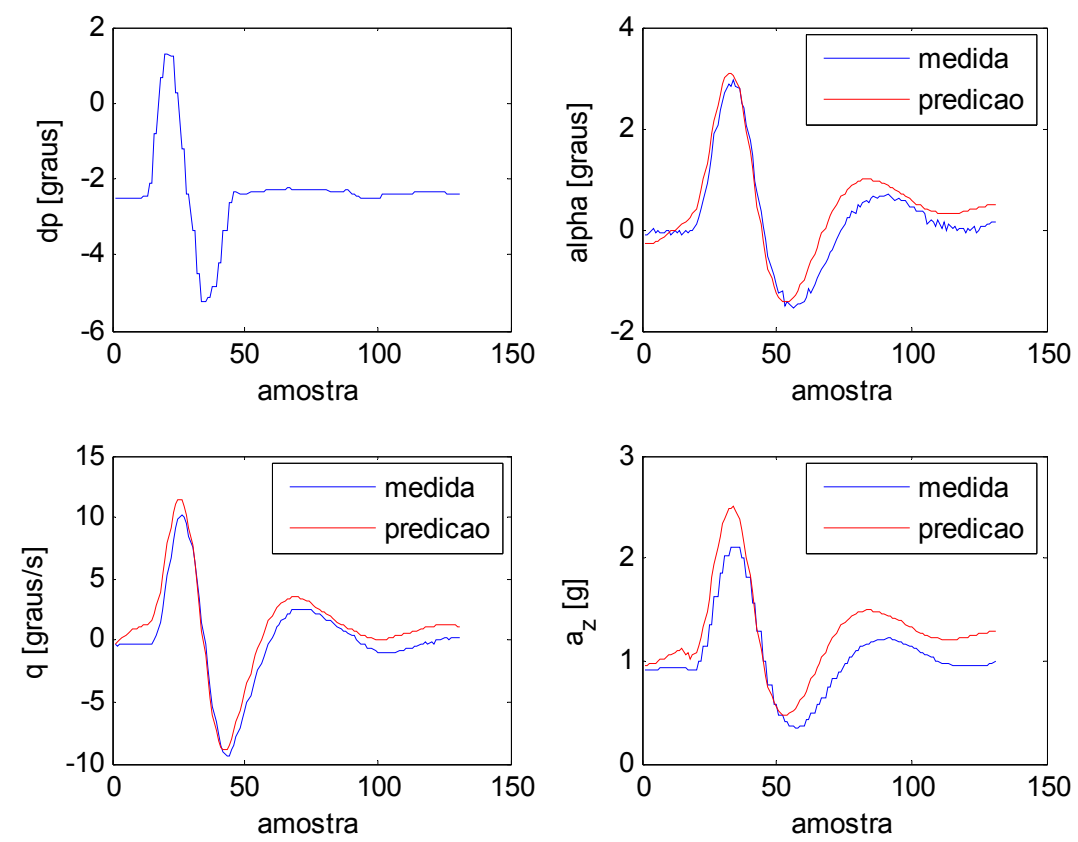

Figura 5.50. Entrada de profundor e gráficos comparativos de respostas obtidas em ensaio em vôo e simuladas usando derivadas estimadas pela RNA correspondentes ao caso 12 do envelope de vôo. 

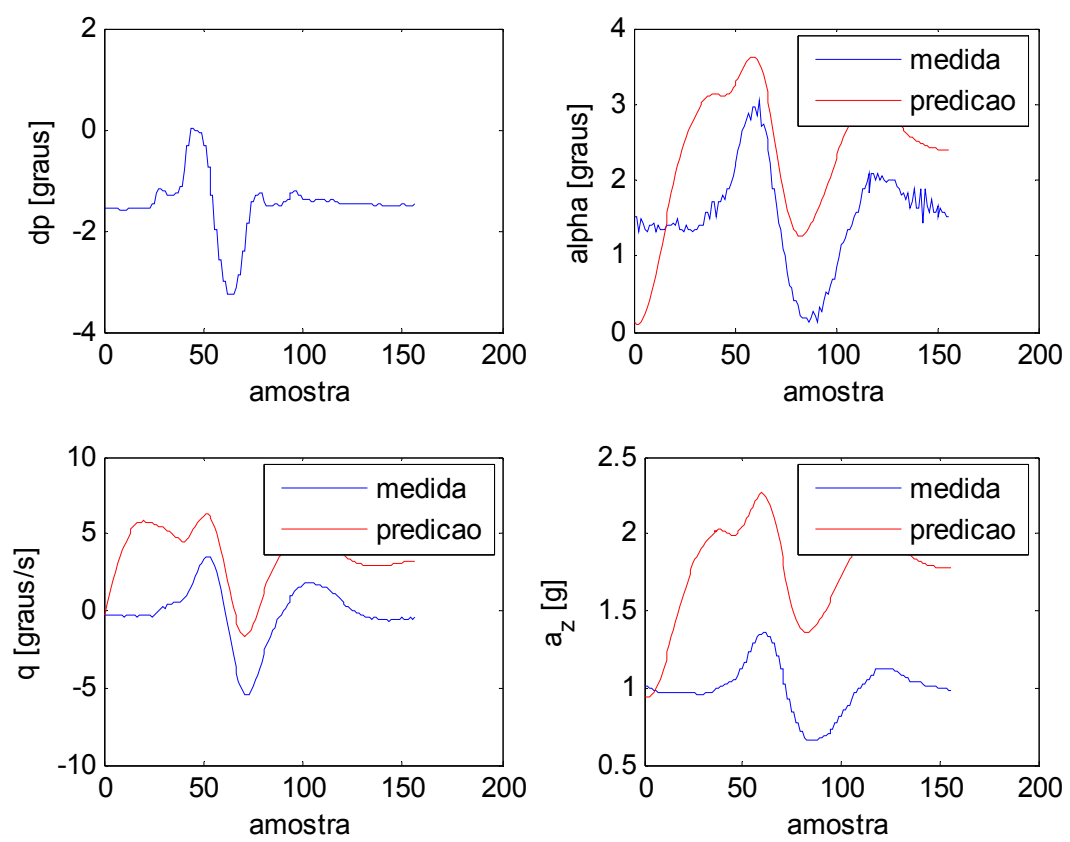

Figura 5.51. Entrada de profundor e gráficos comparativos de respostas obtidas em ensaio em vôo e simuladas usando derivadas estimadas pela RNA correspondentes ao caso 16 do envelope de vôo.
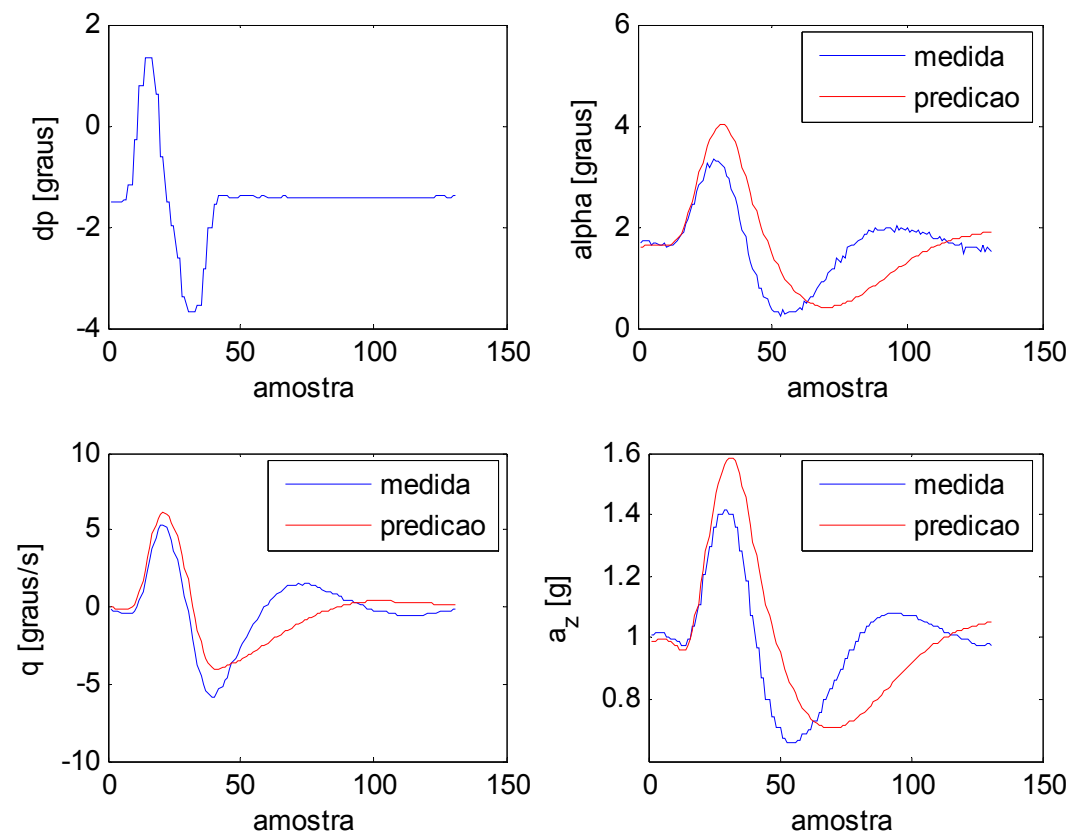

Figura 5.52. Entrada de profundor e gráficos comparativos de respostas obtidas em ensaio em vôo e simuladas usando derivadas estimadas pela RNA correspondentes ao caso 23 do envelope de vôo. 

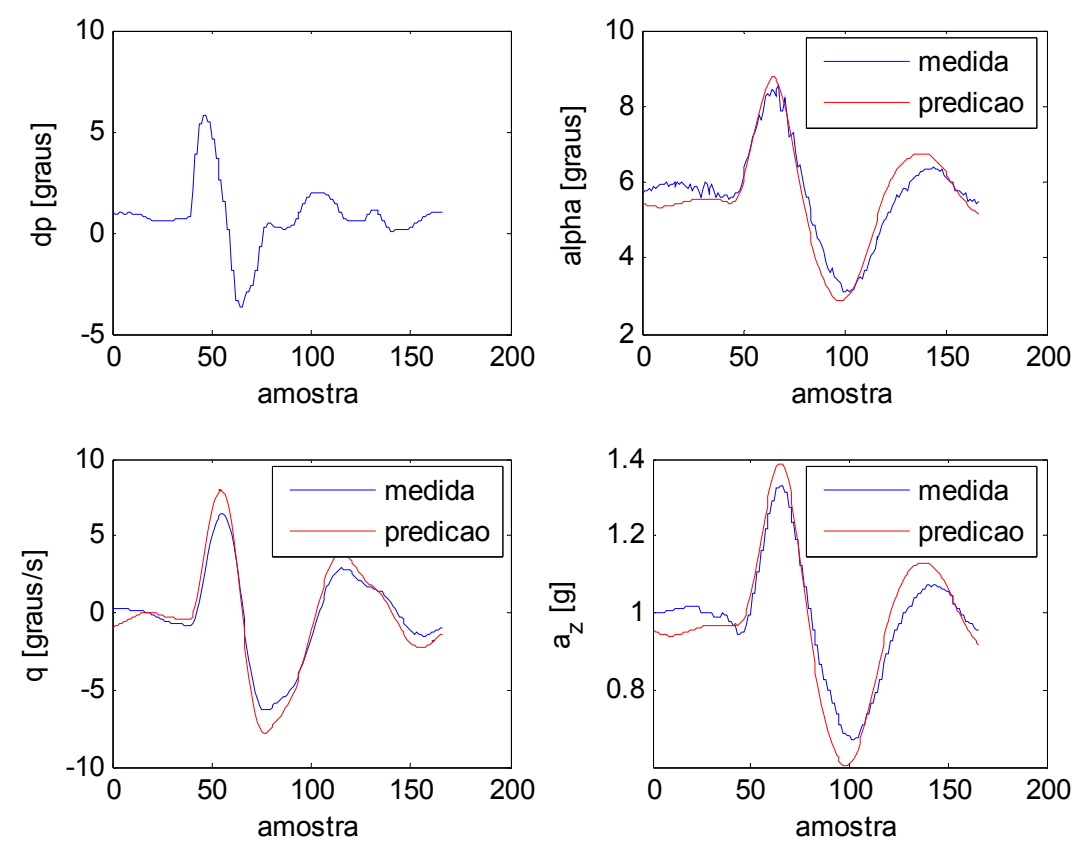

Figura 5.53. Entrada de profundor e gráficos comparativos de respostas obtidas em ensaio em vôo e simuladas usando derivadas estimadas pela RNA correspondentes ao caso 29 do envelope de vôo.
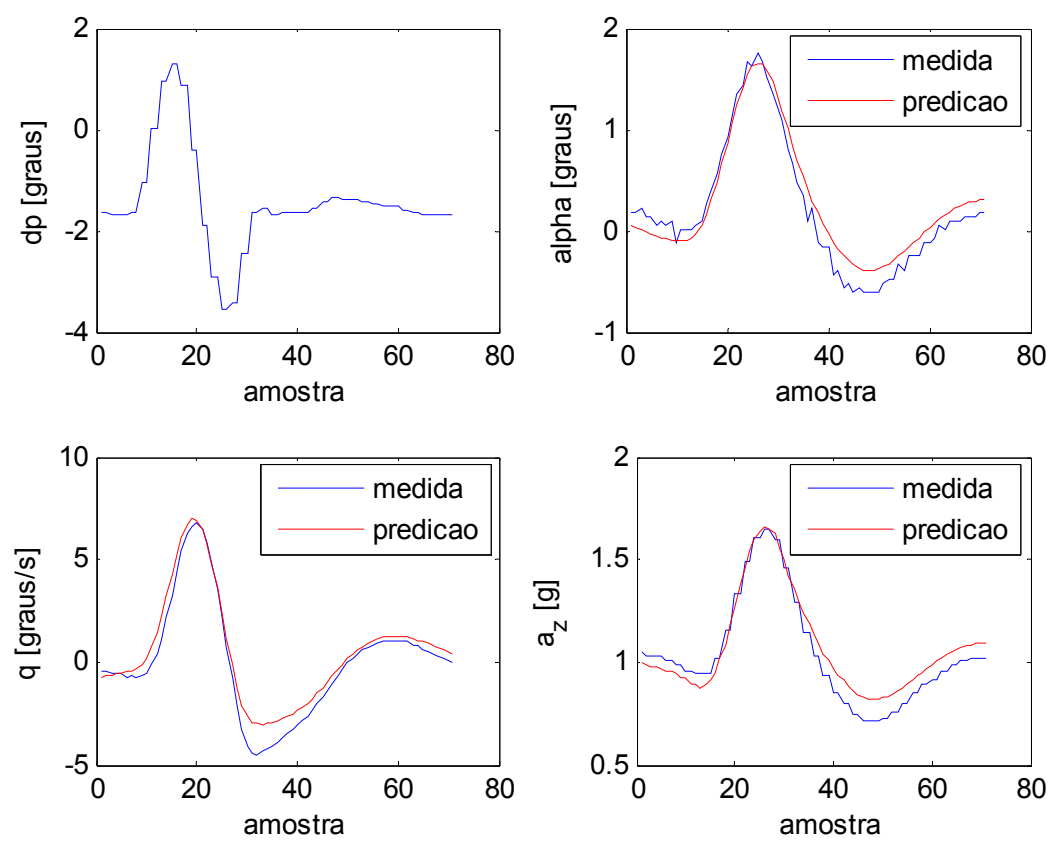

Figura 5.54. Entrada de profundor e gráficos comparativos de respostas obtidas em ensaio em vôo e simuladas usando derivadas estimadas pela RNA correspondentes ao caso 51 do envelope de vôo. 

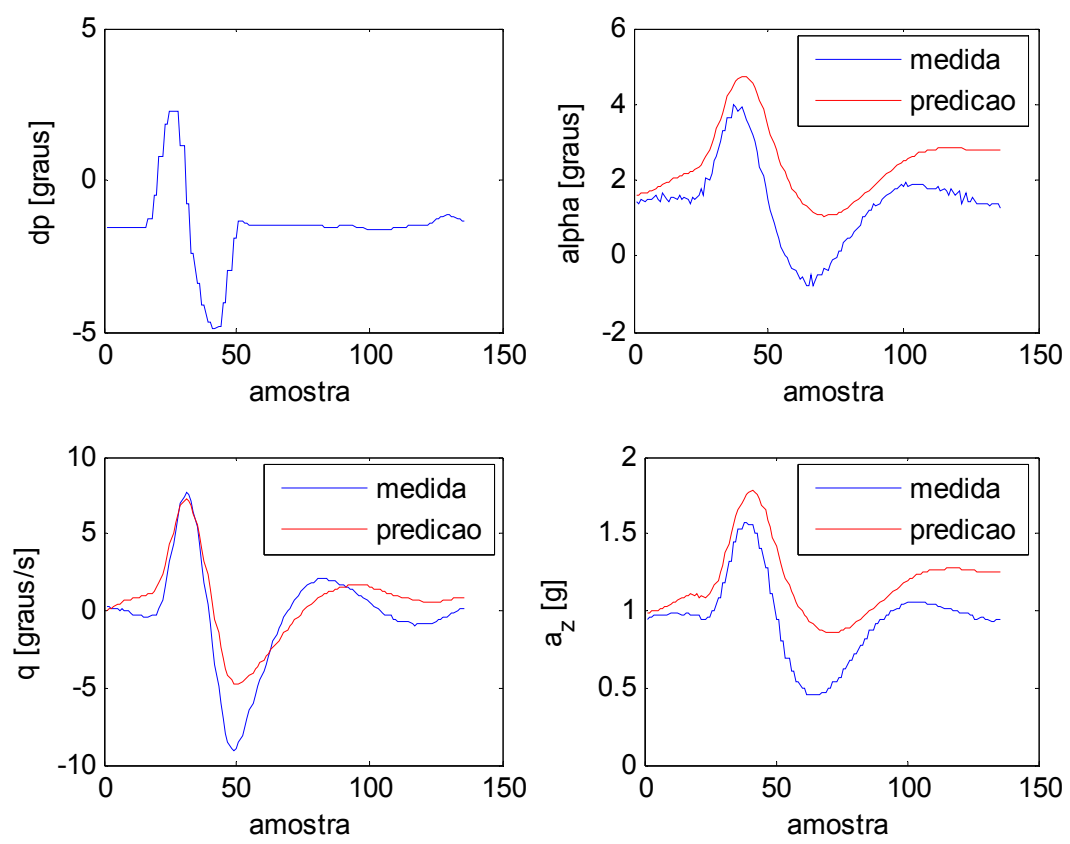

Figura 5.55. Entrada de profundor e gráficos comparativos de respostas obtidas em ensaio em vôo e simuladas usando derivadas estimadas pela RNA correspondentes ao caso 24 do envelope de vôo.
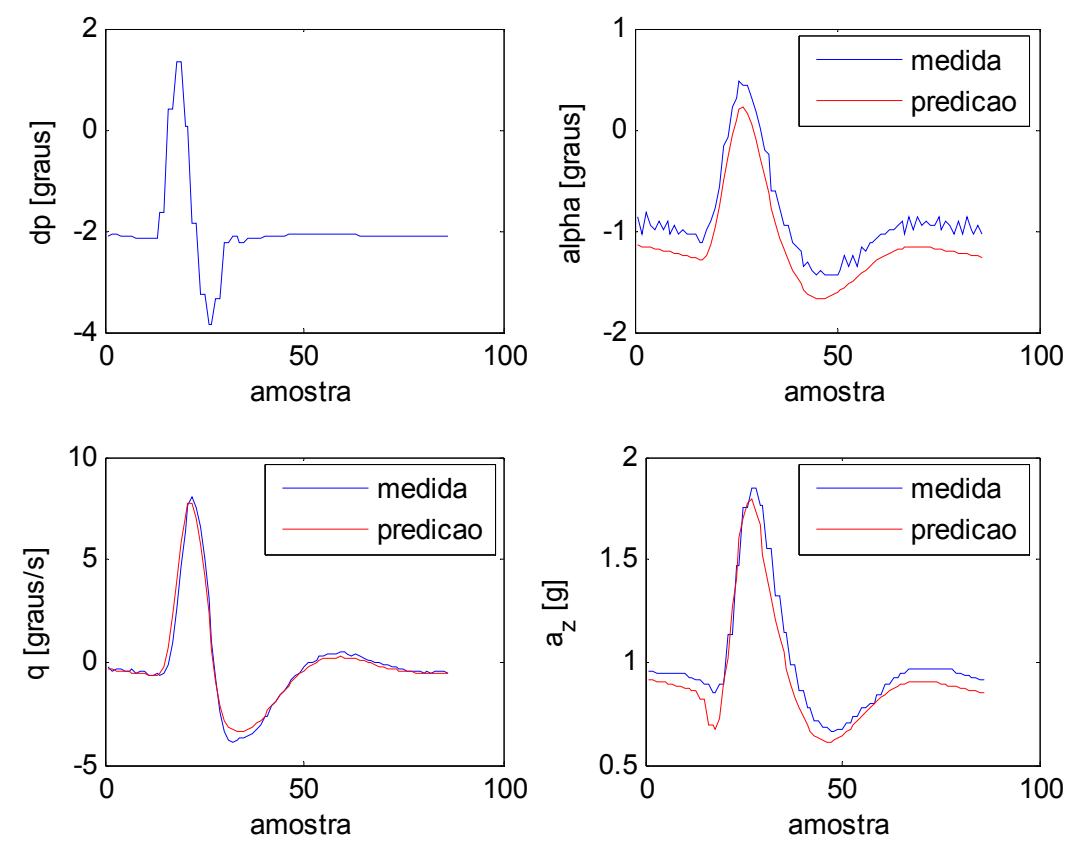

Figura 5.56. Entrada de profundor e gráficos comparativos de respostas obtidas em ensaio em vôo e simuladas usando derivadas estimadas pela RNA correspondentes ao caso 39 do envelope de vôo. 

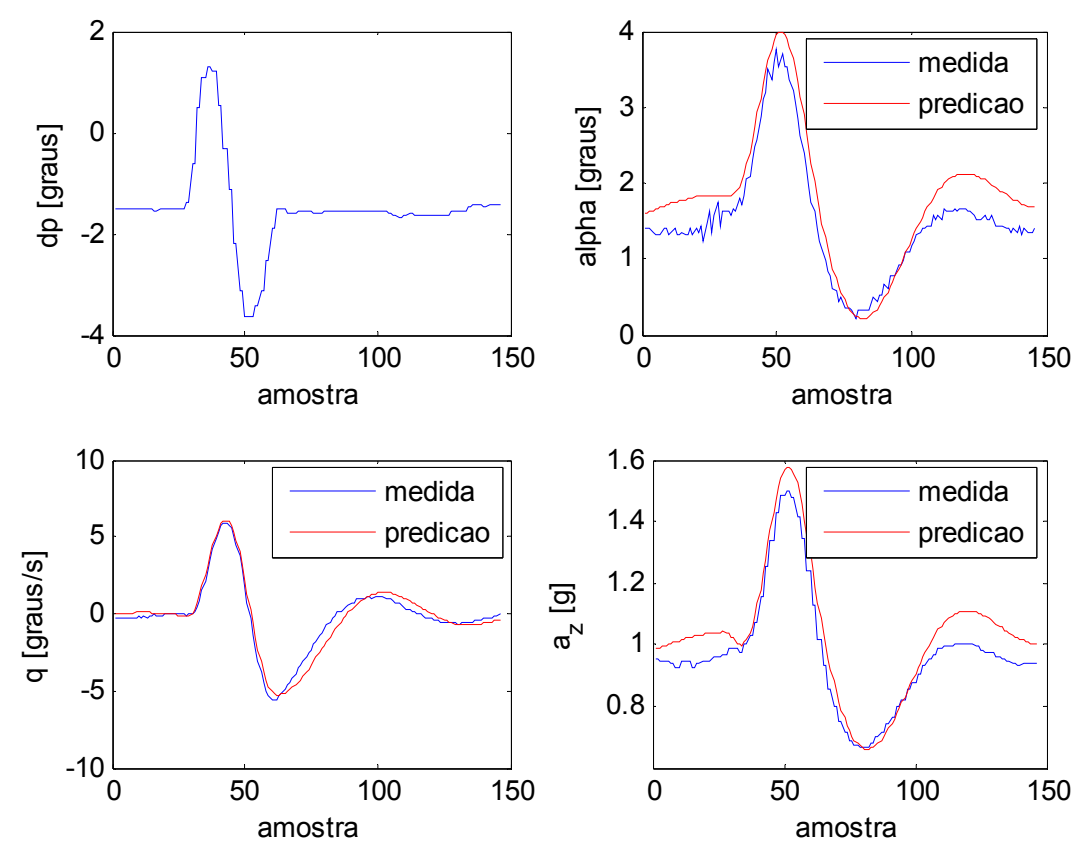

Figura 5.57. Entrada de profundor e gráficos comparativos de respostas obtidas em ensaio em vôo e simuladas usando derivadas estimadas pela RNA correspondentes ao caso 19 do envelope de vôo.

\subsection{Conclusões}

Neste Capítulo foi mostrada a capacidade das RNA's com topologias relativamente simples, na estimação de derivadas aerodinâmicas de estabilidade e de controle de aeronaves. Foi mostrado que quando são conhecidas as derivadas aerodinâmicas em alguns pontos de um envelope de vôo é possível estimar as derivadas da aeronave em qualquer outro ponto do envelope. Dois exemplos foram mostrados, um usando resultados obtidos em simulação e um usando dados reais obtidos em ensaio em vôo. Na aplicação ao problema simulado foram obtidos resultados bastante razoáveis, mas conclui-se que faltou informação para a rede neural durante treinamento. Para mostrar a metodologia aplicada a dados reais foram usados dados obtidos em ensaio em vôo da aeronave Xavante AT-26 da Força Aérea Brasileira. Os resultados foram bastante satisfatórios. A rede foi treinada usando dados correspondentes a 6 condições dentro de um envelope de vôo e, depois de verificada sua capacidade de generalizar, foi usada para estimar as derivadas dos outros pontos do envelope de vôo. Para verificar os resultados obtidos, foram plotados gráficos mostrando comparações entre as respostas obtidas em simulação usando as derivadas estimadas com as respostas reais, medidas em ensaio em vôo, podendo verificar que os resultados foram bastante satisfatórios. Conclui-se que as RNA's, depois de treinadas, são capazes de estimar as derivadas da 
aeronave em outros pontos do envelope de vôo desconhecidos por ela, ou seja, mostrou-se que é possível estimar as derivadas aerodinâmicas de estabilidade e de controle de uma aeronave dentro de um extenso envelope de vôo. 


\section{CAPÍTULO 6}

\section{CONSIDERAÇÕES FINAIS}

\subsection{Conclusões}

Neste trabalho foi demonstrada a eficiência das redes neurais artificiais recorrentes na identificação das respostas de aeronaves dentro de um envelope de vôo e a capacidade de estimação de derivadas de controle e estabilidade das redes neurais artificiais feedforward com topologias bastante simples.

Para mostrar a aplicação específica na identificação rápida e eficiente de respostas de uma aeronave de asa fixa dentro de um envelope de vôo pré-estabelecido, foram usadas redes neurais recorrentes com atrasos no tempo. Para este propósito foram usadas respostas simuladas de uma aeronave, obtidas após implementação do modelo matemático não linear de dinâmica de vôo de aeronaves fornecido por ETKIN (1996). Para o estudo de caso foi simulado o modelo da aeronave militar de ataque A4-D, cujos dados foram obtidos da literatura.

A aeronave foi simulada em 9 pontos distintos de um envelope de vôo com Mach e altitude distintos. A rede neural recorrente foi treinada usando dados referentes a 4 destes pontos usando como entrada dinâmica a entrada dada no profundor e entradas estáticas Mach e altitude da aeronave. Para treinar a rede foram usados apenas resultados de simulações realizadas usando entrada degrau nos profundores. Depois de devidamente treinada, a rede neural identificou de forma rápida e com grande precisão as respostas de $q, w$ e $u$ da aeronave nos outros 5 pontos do envelope de vôo, usando diferentes tipos de entradas nos profundores. 
Em seguida foi apresentada a resolução do problema inverso. Foram usadas como entradas para a rede neural respostas da aeronave juntamente com alguns dados geométricos e como saídas derivadas aerodinâmicas de estabilidade. Depois de realizado o treinamento, este modelo neural estimou as derivadas aerodinâmicas de estabilidade da aeronave. Dois casos foram apresentados: um primeiro usando os dados da aeronave simulada e um segundo usando dados obtidos em ensaio em vôo da aeronave Xavante da força aérea brasileira.

No primeiro caso foram usadas para treinar as redes neurais respostas da aeronave referentes aos mesmos 4 pontos do envelope nos quais foram identificadas as respostas. Para generalizar foram usadas as respostas referentes aos outros 5 pontos do envelope de vôo. Foram implementadas 3 redes neurais separadas para identificar as derivadas como foi mostrado no trabalho. Os resultados obtidos foram pouco satisfatórios, concluindo-se então que para treinar a rede neural seria necessário outro conjunto de dados de entradas e saídas obtidos da simulação de outras manobras mais ricas em informações do comportamento dinâmico da aeronave. Esta conclusão foi tirada após a realização do segundo exemplo, usando os dados obtidos em ensaio em vôo, com várias manobras distintas realizadas que apresentou resultados bastante satisfatórios. Neste segundo exemplo, usou-se apenas uma rede neural para identificar as derivadas de estabilidade e de controle já que os vetores de entrada possuíam pequeno número de pontos.

Ao fim deste trabalho, concluiu-se que os modelos neurais, depois de devidamente treinados usando pequeno número de condições conhecidas, são capazes de identificar o comportamento de uma aeronave dentro de um extenso envelope de vôo. Pôde-se verificar também que, se forem conhecidas as derivadas aerodinâmicas da aeronave referentes a algumas condições de vôo, podem-se usar as respostas da aeronave juntamente com seus dados geométricos para estimar as derivadas de estabilidade e de controle em qualquer outro ponto de um envelope de vôo e em qualquer situação de vôo.

Conclui-se então que é possível identificar as respostas da aeronave em qualquer ponto do envelope de vôo e que usando estas respostas e conhecendo-se as derivadas relativas a algumas condições de vôo é possível estimar as derivadas. Portanto foi mostrado que esta metodologia apresenta uma grande redução de tempo na obtenção das derivadas.

\subsection{Propostas de continuidade do trabalho}

Como se pôde observar na Tese, para usar as redes neurais na estimação das derivadas aerodinâmicas, é necessário que se conheça alguns conjuntos destas, referentes a algumas 
condições de vôo, para usar durante treinamento. Isto dificulta a aplicação do método já que estas não são facilmente encontradas. Portanto, uma proposta de continuidade deste trabalho é desenvolver uma forma de treinar a rede neural sem usar como saídas derivadas aerodinâmicas. Sugere-se também a realização de análise de condições vôo em pontos extremos do envelope de vôo apresentado e em pontos fora deste, ou seja, sugere-se a tentativa de extrapolação deste. 


\section{REFERÊNCIAS BIBLIOGRÁFICAS}

ALLEN, M. J.\& DIBLEY, R. P. (2003). Modeling Aircraft Wing Loads from Flight Data Using Neural Networks. Dryden Flight Research Center Edwards, California 93523-0273.

COOPER, J. E. \& CROWTHER, W. J., (1999). Flutter Speed Prediction During Flight Flutter Testing Using Neural Networks. CEAS/AIAA/ICASE/NASA Langley International Forum on Aeroelasticity and Structural Dynamics, p. 255-264.

CRIVELARO, K. C. O. (2004). Utilização de redes neurais auto-organizativas para identificação de regimes de escoamento bifásico horizontal ar-água. São Carlos. 70 p. Tese (Doutorado) - Escola de Engenharia de São Carlos, Universidade de São Paulo.

CRUZ, J.C.G. (1998). Identificação de Uma Torre de Retificação de Águas Ácidas Usando Redes Neurais Artificiais. Minas Gerais. Dissertação de Mestrado. Universidade Federal de Minas Gerais.

CURVO, M., (2001). Modelagem aerodinâmica e Controle Estocástico Adaptativo de Aeronaves de Alto Desempenho por Redes Neurais Artificiais e Estimação de Parâmetros. São José dos Campos. 175 p. Tese (Doutorado) - Intituto Nacional de Pesquisas Espaciais (INPE).

DE MARQUI JR, C. et. al, (2004). Previsão da Velocidade de Flutter Uutilizando Redes Neurais. 17 th International Congress of Mechanical Eingineering. Proceedings of Cobem.

ETKIN, B. \& REID, D. R. (1996). Dynamics of flight: stability and control. $-3^{\text {rd }} \mathrm{ed}$.

FARIA, B. G. (2005). Methodologies definition and validation for the longitudinal dynamic identification of an unmanned robotic airship. Campinas, SP. 
FERREIRA, A. P. C. S. (2005). Identificação do Funcional da Resposta Aeroelástica Via Redes Neurais Artificiais. São Carlos, 2005. 93p. Dissertação (Mestrado) - Escola de Engenharia de São Carlos, Universidade de São Paulo.

HAGAN, M. T.; DEMUTH, H. B.; BEALE, M. (1996). Neural network design. Boston, PWS Publishing Company.

HAMEL, P. G.; JATEGAONKAR, R. V. (1996). Evolution of Flight Vehicle System Identification. Journal of Aircraft, v. 33, n. 1.

HAYKIN, S. (1999). Neural network a comprehensive foundation. New York, Macmillan College Publishing Company.

HORN, J. et al (1998). Flight Envelope Cueing on a Tilt-Rotor Aircraft using Neural Network Limit Prediction. Present at the American Helicopter Society $-54^{\text {th }}$ Forum. Washington, D. C., May 20-22.

ILIFF, K. W. \& WANG, K. C. (1997). Extration of Lateral-Directional Stability and Control Derivatives for the Basic F-18 Aircraft at High Angles of Attack. Nasa Technical Memorandum 4786.

IYODA, E. M (2000). Inteligência computacional no projeto automático de redes neurais híbridas e redes neurofuzzy heterogêneas. Campinas. Dissertação (Mestrado). Universidade de Campinas.

JATEGAONKAR, R.; FISCHENBERG D.; GRUENHAGEN VON W. (2003). Aerodynamic Modeling and System Identification from Flight Data - Recent Applications at DLR. Anais do DINCON, v.2.

KLEIN, V. (1989). Estimation of Aircraft Aerodynamic Parameters from Flight Data. Prog. Aerospace Sci. Vol. 26, pp.1-77.

KLING, R. (2003). An Implementation of Recurrent Neural Networks for Prediction and Control of Nonlinear Dynamic Systems. MSc Thesis. Monash University in Melbourne in Australia. 
KOHONEN, T. (2001). Self-organizing maps. Finland, Springer.

LEONTARITIS, I. \& BILLINGS, S. (1985): Input- output parametric models for nonlinear systems: Part I: Deterministic nonlinear systems. International Journal of Control, Vol. 41, pp. 303-328.

LIANG, Z. (2002). Redes neurais: Introdução: Histórico.Instituto de Ciências Matemáticas e Computação. São Carlos. São Paulo/ Notas de Aula.

LIN, T.; HORNE, B.G.; TINO, P.; GILES, C.L. (1996): Learning long term dependencies in NARX recurrent neural networks. IEEE Trans on Neural Networks, Vol. 7, pp. 1329-1338.

LINSE, D. J. \& STENGEL, R. (1993). Identification of Aerodynamic Coefficients Using Computational Neural Networks. Journal of Guidance, Control and Dynamics. v. 16, n. 6, p. 1018-1025.

MACIEL, B. et al. (2007). Identificação das Derivadas de Estabilidade e Controle o movimento Longitudinal da Aeronave Xavante AT-26 usando Estimação por Máxima Verossimilhança. Aceito para publicação. Revista Controle \& Automação, v.X.

MARQUES, F. D. (2003). Introdução à Dinâmica de Vôo, Equacionamento e Simulação: Problemas não Lineares e Aplicações. Anais do DINCON, v. 2, p. 38-61.

MARQUES, F. D. (2004). Introdução à Dinâmica de Vôo. Notas de aulas.

MARQUES, F.D. et. al (2005). Application of Time-Delay Neural and Recurrent Neural Networks for Identification of a Hingeless Helicopter Blade Flapping and Torsion motions. Journal of the Braz. Soc. of Mech. Sci. \& Eng, v. XXVII, n. 2 / 97. Copyright (C) 2005 by ABCM.

MENDONÇA, C. B.; GÓES, L. C.S. (2003). Airplane Parameter Identification Using Frequency Response Error Method. 17 th International Congress of Mechanical Eingineering. Proceedings of Cobem.

McCULLOCH, W. S. \& PITTS, W. (1943). A logical calculus of the ideas immanent in nervous activity. Bulletin of mathematical biophysics, v.5, p.115-133. 
McRUER, D.; ASHKENAS, I.; GRAHAM, D. (1973). Aircraft Dynamics and Automatic Control. - Princenton University Press. Princeton, New Jersey.

MORELLI, E. A., (1998). In-Flight System Identification. AIAA-98-4261.

MORELLI, E. A., (1999). Real - Time Parameter Estimation in the Frequency Domain. AIAA-994043.

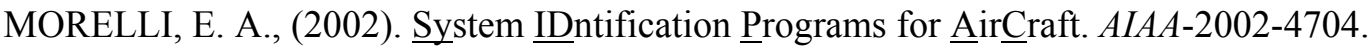

NAKO, A. C., (2003). Modelagem, Simulação e Identificação de Parâmetros de Aeronaves via Técnica de Erro de Saida: Trabalho de Graduação. - Ita, São José Dos Campos.

NARENDRA, K. S.; PARTHASARATHY (1990). Identification and Control of Dynamical Systems Using Neural Networks. IEEE Transactions on Neural Networks, v.1, n.1.

NETO, W. R.; CURVO, M. \& GÓES, L. C. S (2005). Aircraft Parameter Estimation Using Adaptative Functional Link Network. 18 th International Congress of Mechanical Eingineering. Proceedings of Cobem.

RAISINGHANI, S. C.; GHOSH, A. K., (2000). Parameter estimation of an aeroelastic aircraft using neural networks. Sãdhanã, v. 25, Part 2, pp. 181-191.

REBOLHO, D. C. et al. (2006). Application of EERA Method for Identification of Modal Parameters of a Simulated Aircraft. III European Conference on Computational Mechanics Solids, Structures and Coupled Problems in Engeneering. Lisbon, Portugal, 5-8 June. C.A. Mota Soares et.al. (eds.)

RUMELHART, D.; HINTON, G. \& WILLIANS, R. (1986). Learning Internal Representationsby Error Propagation. In: Rumelhart \& McClelland: Parallel Distributed Processing - Explorations in the Microstructure of Cognition - Vol.1: Foundations. Cambridge: MIT Press. 
SARAVANAN, N.; DUYAR, A. (1994). Modeling Space Shuttle Main Engine Using FeedForward Neural Networks. Journal of Guidance, Control and Dynamics, v. 17, n.4., p.641648.

SCHIMIDT, L. V. (1998). Introduction to Aircraft Flight Dynamics. American Institute of Aeronautics, Inc., Reston, Virginia.

SIEGLEMANN, H.; HORNE, B.; GILES, L. (1997): Computational Capabilities or recurrent NARX neural networks. IEEE Trans System, Man and Cybernetics. Part B, Vol 27, pp. 208218.

SIM, G. (1997). A correlation Between Flight-Determined Derivatives and Wind-Tunnel Data for the X-24B Research Aircraft. NASA Service Technical Memorandum SX-3371.

SOUZA, L. F. R. (2002). Identification of the dynamics non linear of a blade of helicopter through neural networks. São Carlos, 2002. 92p. Dissertação (Mestrado) - Escola de Engenharia de São Carlos, Universidade de São Paulo.

SOUZA, L. F. R. ET AL., (2005). Simulation and Identification of a Flight Envelope using Neural Networks. Proceedings of COBEM 2005 Ouro Preto, MG. Copyright (C 2005 by ABCM.

TISCHLER, M. B. (1995). System Identification Methods for Aircraft Flight Control Development and Validation. Moffett Field, CA: NASA Ames Research Center. 22 p.

TOSTES, A. S. M. \& GOES, L. S. (2003). Identificação dos modos longitudinal e LateralDirecional de aeronaves de asa fixa via Técnicas de Subespaço. Série Arquimedes, Anais do DINCON, v. 2, p. 383-390.

TSOI, A.C. (1998). Recurrent Neural Network Architectures an Overview, In: Cirles, C.L. \& Ciani, M., Editors. Adaptive Processes of Sequences and Data Structure, Springer-Verlag, pp $1-26$.

VASCONCELOS, L. J. H. (2002). Identificação Paramétrica de Derivadas de Estabilidade e Controle Longitudinais da Aeronave Xavante AT-26. São José dos Campos, SP. 


\section{APÊNDICE}

As modificações feitas com as derivadas de movimento longitudinal são apresentadas a seguir e destaca-se que todas as derivadas com índice sobrescrito "s" foram definidas por SHIMIDT, (1998) e as sem índices definidas segundo ETKIN \& REID, (1996).

$$
\begin{array}{ll}
X_{u}=X_{u}^{s} \cdot m \rightarrow[\mathrm{kg} / \mathrm{s}] & X_{w}=\frac{X_{\alpha}^{s}}{V} \cdot m \rightarrow[\mathrm{kg} / \mathrm{s}] \\
Z_{u}=Z_{u}^{s} \cdot m \rightarrow[\mathrm{kg} / \mathrm{s}] & Z_{w}=\frac{Z_{\alpha}^{s}}{V} \cdot \mathrm{m} \rightarrow[\mathrm{kg} / \mathrm{s}] \quad Z_{q}=Z_{q}^{s} \cdot \mathrm{m} \rightarrow[\mathrm{kg} \cdot \mathrm{m} / \mathrm{s}] \\
M_{u}=M_{u}^{s} \cdot I_{y} \rightarrow[\mathrm{kg} \cdot \mathrm{m} / \mathrm{s}] & M_{w}=\frac{M_{\alpha}^{s}}{V} \cdot I_{y} \rightarrow[\mathrm{kg} \cdot \mathrm{m} / \mathrm{s}] \quad M_{q}=M_{q}^{s} \cdot I_{y} \rightarrow\left[\mathrm{kg} \cdot \mathrm{m}^{2} / \mathrm{s}\right] \\
M_{\dot{w}}=\frac{M_{\dot{\alpha}}^{s}}{V} \cdot I_{y} \rightarrow[\mathrm{kg} \cdot \mathrm{m}] & Z_{\dot{w}}=\frac{Z_{\dot{\alpha}}^{s}}{V} \cdot \mathrm{m} \rightarrow[\mathrm{kg}] \\
\Delta X_{\delta e}=X_{\delta e}^{s} \cdot m \rightarrow\left[\mathrm{kg} \cdot \mathrm{m} / \mathrm{s}^{2}\right] & \Delta Z_{\delta e}=Z_{\delta e}^{s} \cdot m \rightarrow\left[\mathrm{kg} \cdot \mathrm{m} / \mathrm{s}^{2}\right] \quad \Delta M_{\delta e}=M_{\delta e}^{s} \cdot I_{y} \rightarrow\left[\mathrm{kg} \cdot \mathrm{m}^{2} / \mathrm{s}^{2}\right]
\end{array}
$$

e com relação às derivadas de movimento lateral, deve ser feito o seguinte:

$$
Y_{v}=\frac{Y_{\beta}^{s}}{V} \cdot m \rightarrow[\mathrm{kg} / \mathrm{s}] \quad Y_{p}=Y_{p}^{s} \cdot m \rightarrow[\mathrm{kg} \cdot \mathrm{m} / \mathrm{s}] \quad Y_{r}=Y_{r}^{s} \cdot \mathrm{m} \rightarrow[\mathrm{kg} \cdot \mathrm{m} / \mathrm{s}]
$$




$$
\begin{array}{lll}
L_{v}=\frac{L_{\beta}^{s}}{V} \cdot I_{x} \rightarrow[\mathrm{kg} \cdot \mathrm{m} / \mathrm{s}] & L_{p}=L_{p}^{s} \cdot I_{x} \rightarrow\left[\mathrm{kg} \cdot \mathrm{m}^{2} / \mathrm{s}\right] & L_{r}=L_{r}^{s} \cdot I_{x} \rightarrow\left[\mathrm{kg} \cdot \mathrm{m}^{2} / \mathrm{s}\right] \\
N_{v}=\frac{N_{\beta}^{s}}{V} \cdot I_{z} \rightarrow[\mathrm{kg} \cdot \mathrm{m} / \mathrm{s}] & N_{p}=N_{p}^{s} \cdot I_{z} \rightarrow\left[\mathrm{kg} \cdot \mathrm{m}^{2} / \mathrm{s}\right] & N_{r}=N_{r}^{s} \cdot I_{z} \rightarrow\left[\mathrm{kg} \cdot \mathrm{m}^{2} / \mathrm{s}\right] \\
\Delta Y_{\delta a}=Y_{\delta a}^{s} \cdot m \rightarrow\left[\mathrm{kg} \cdot \mathrm{m} / \mathrm{s}^{2}\right] & \Delta L_{\delta a}=L_{\delta a}^{s} \cdot I_{x} \rightarrow\left[\mathrm{kg} \cdot \mathrm{m}^{2} / \mathrm{s}^{2}\right] & \Delta N_{\delta a}=N_{\delta a}^{s} \cdot I_{z} \rightarrow\left[\mathrm{kg} \cdot \mathrm{m}^{2} / \mathrm{s}^{2}\right]
\end{array}
$$

